\title{
PHÁT TRIỂN TÀI CHÍNH VÀ TĂNG TRƯởNG KINH TẾ
}

\author{
Phạm Dương Phương Thảo
}

October 27, 2019

TRƯỜNG ĐẠI HOC KINH TẾTP. HỒ CHÍ MINH

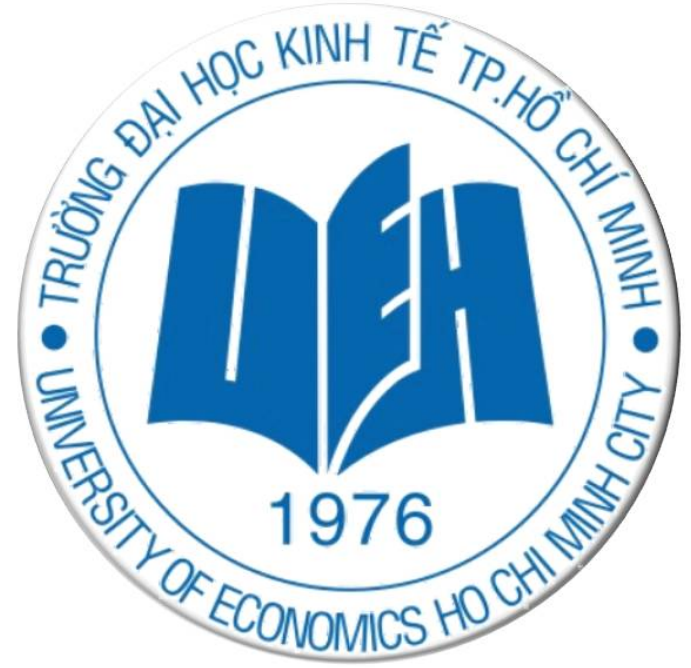

Thành phố Hồ Chí Minh, 2019 


\title{
Bộ GIÁO DỤC VÀ ĐÀO TẠO \\ TRƯờNG ĐẠI HỌC KINH TẾ TP. HỔ CHÍ MINH
}

\author{
Phạm Dương Phương Thảo
}

\section{PHÁT TRIỄN TÀI CHÍNH \\ VÀ TĂNG TRƯỞNG KINH TẾ}

LUẬN ÁN TIÊN SĨ KINH TÉ

Tp. Hồ Chí Minh - Năm 2019 


\title{
Bộ GIÁO DỤC VÀ ĐÀO TẠO \\ TRƯờNG ĐẠI HỌC KINH TẾ TP. HỔ CHÍ MINH
}

\author{
Phạm Dương Phương Thảo
}

\section{PHÁT TRIỀn TÀI CHÍNH \\ VÀ TĂNG TRƯỞNG KINH TẾ}

Chuyên ngành: Tài chính - Ngân hàng Mã số: 9340201

LUẬN ÁN TIẾN SĨ KINH TẾ

NGƯỜI HƯỚNG DÃ̃N KHOA HỌC: PGS.TS. PHAN THỊ BÍCH NGUYỆT

Tp. Hồ Chí Minh - Năm 2019 
Trang i

\section{LỜI CAM ĐOAN}

Tôi xin cam đoan luận án tiến sĩ với đề tài "Phát triển tài chính và Tăng trưởng kinh tế" là công trình nghiên cứu độc lập của tôi. Các thông tin, số liệu trong luận án là trung thực, có nguồn gốc trích dẫn rõ ràng, cụ thể và chưa từng được công bố trong bất kỳ công trình nghiên cứu nào khác.

TP.HCM, ngày 01 tháng 09 năm 2019

Nghiên cứu sinh 


\section{MỤC LỤC}

\section{Contents}

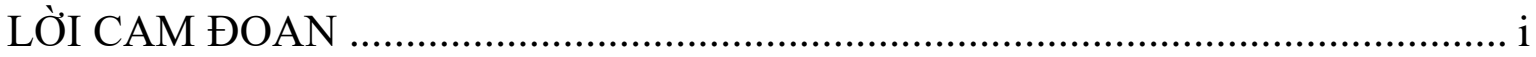

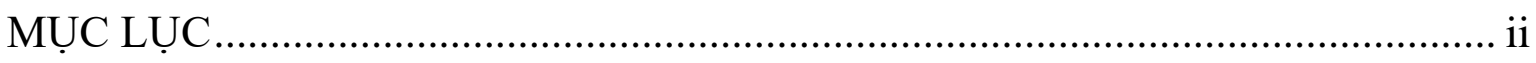

DANH MỤC TỬ VIẾT TẮT ...................................................................... vi

DANH MỤC BẢNG ............................................................................... vii

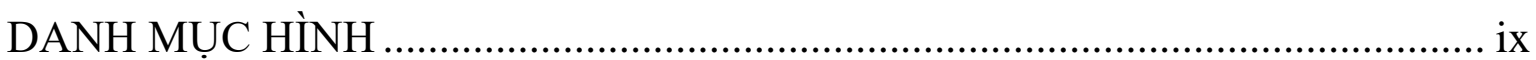

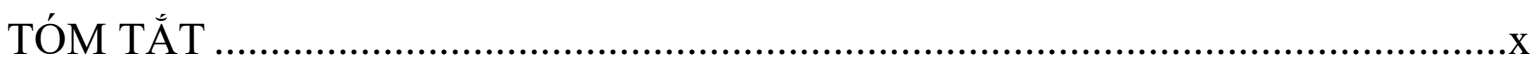

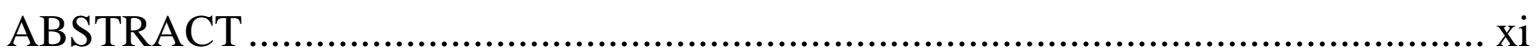

CHƯƠNG 1 MỞ ĐẦU ........................................................................

1.1. Bối cảnh nghiên cứu của luận án ................................................................. 1

1.2. Khoảng trống nghiên cứu.........................................................................4

1.3. Vấn đề nghiên cứu và mục tiêu nghiên cứu ...................................................6

1.4. Đối tượng và phạm vi nghiên cứu ................................................................

1.5. Phương pháp nghiên cứu...................................................................

1.6. Tóm tắt kết quả nghiên cứu .................................................................. 11

1.7. Những đóng góp của luận án ................................................................ 12

1.8. Kết cấu của luận án ................................................................................ 13

CHƯƠNG 2 TỔNG QUAN LÝ THUYÊT VÀ CÁC NGHIÊN CÚU TRƯỚC

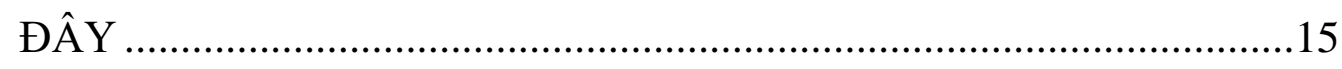

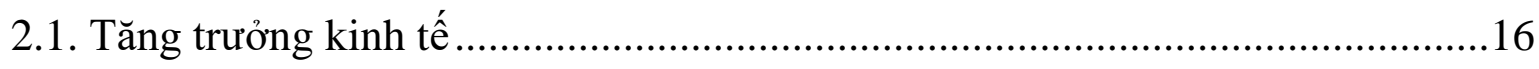

2.1.1. Phân biệt Tăng trưởng kinh tế và Phát triển kinh tế................................16

2.1.2. Hàm sản xuất ............................................................................ 16 


\section{Trang iii}

2.1.3. Đo lường tăng trưởng kinh tế

2.2. Phát triển tài chính

2.2.1. Hệ thống tài chính 18

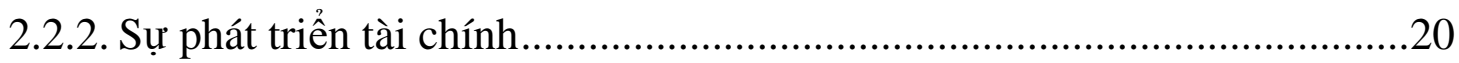

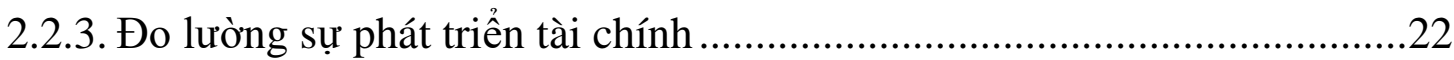

2.2.3.1. Tỷ số tín dụng cho khu vực tư nhân trên GDP ..................................22

2.2.3.2. Tỷ số tín dụng nội địa trên GDP .....................................................23

2.2.3.3. Tỷ số cung tiền trên GDP.................................................................23

2.2.3.4. Các chỉ tiêu đo lường về thị trường tài chính so với GDP..............25

2.2.3.5. Các phương pháp đo lường khác ...................................................26

2.3. Vai trò của phát triển tài chính trong các lý thuyết tăng trưởng kinh tế..............30

2.4. Bằng chứng thực nghiệm tác động của Phát triển tài chính đến Tăng trưởng kinh tế 35

2.4.1. Tác động tích cực của Phát triển tài chính đến tăng trưởng kinh tế...........36

2.4.2. Quan điểm hoài nghi về vai trò thúc đẩy của phát triển tài chính.............41

2.4.3. Quan hệ phi tuyến giữa Phát triển tài chính và Tăng trưởng kinh tế .......42

2.4.4. Nghiên cứu thực nghiệm ở các nước châu Á ............................................49

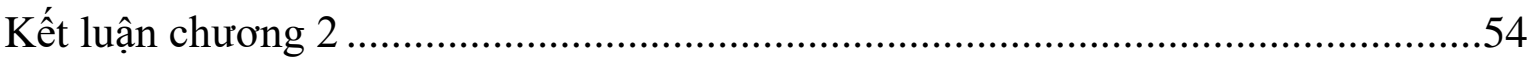

CHƯƠNG 3 PHƯƠNG PHÁP NGHIÊN CÚU ……………………....................5

3.1. Câu hỏi nghiên cứu và giả thuyết nghiên cứu.....................................................5

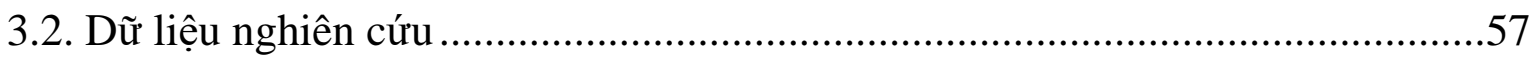

3.3. Mô hình nghiên cứu ....................................................................................60

3.4. Các biến số trong mô hình ..............................................................................63

3.4.1. Biến phụ thuộc (Tăng trưởng kinh tế - GROWTH) ...................................63 
3.4.2. Biến độc lập (Phát triển tài chính - FD)..................................................64

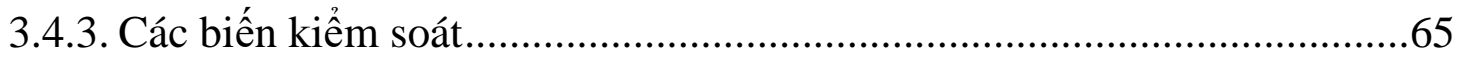

3.5. Phương pháp ước lượng .................................................................................

3.5.1. Phương pháp hồi quy ngưỡng dành cho dữ liệu bảng ...............................73

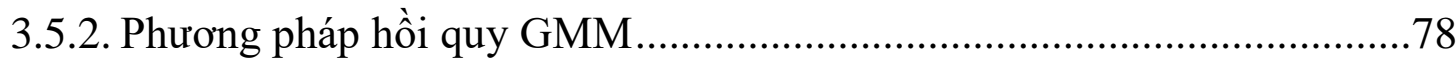

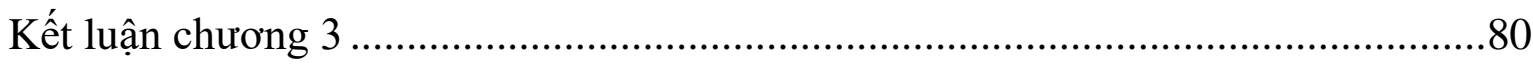

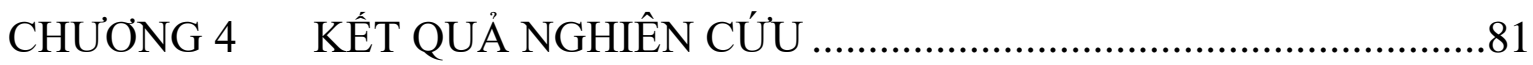

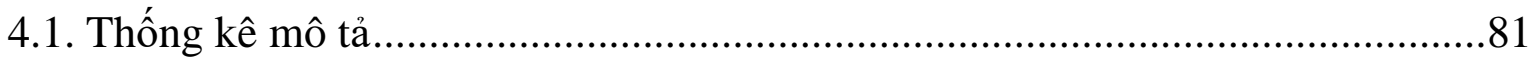

4.2. Phân tích tác động phi tuyến của phát triển tài chính đến tăng trưởng kinh tế

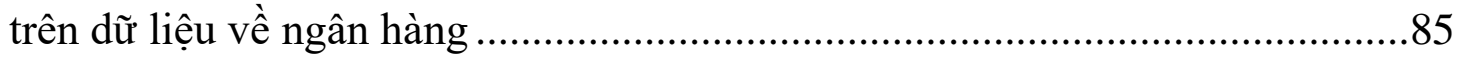

4.2.1. Kết quả hồi quy ngưỡng ..........................................................................85

4.2.1.1. Tín dụng cho khu vực tư nhân ...........................................................

4.2.1.2. Tín dụng trong nước......................................................................92

4.2.1.3. Nợ thanh khoản /GDP .....................................................................94

4.2.2. Kết quả ước lượng system-GMM............................................................99

4.3. Phân tích tác động phi tuyến của phát triển tài chính đến tăng trưởng kinh tế

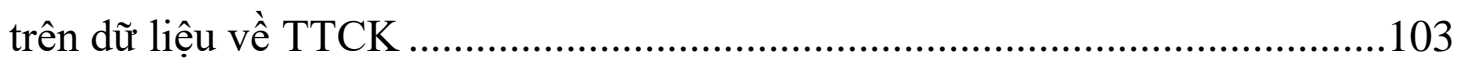

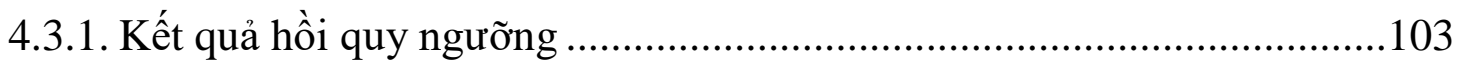

4.3.1.1. Quy mô vốn hóa thị trường ...........................................................103

4.3.1.2. Tỷ suất sinh lợi của TTCK..........................................................106

4.3.1.3. Quy mô giao dịch của TTCK/GDP.................................................107

4.3.2. Kết quả ước lượng GMM ......................................................................111

4.4. Phân tích trên mẫu phụ....................................................................................113

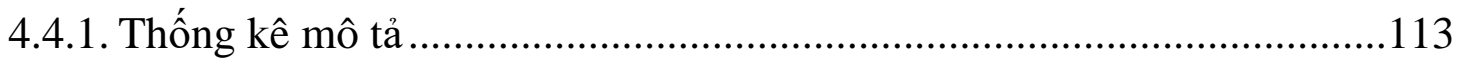


4.4.2. Phân tích mẫu phụ High income

4.4.3. Phân tích mẫu phụ Middle income

Kết luận chương 4

CHƯƠNG 5 GIẢI PHÁP VÀ Ý KIẾN ĐỀ XUÂT PHÁT TRIỂN TÀI CHÍNH

ĐỂ TĂNG TRƯỞNG KINH TẾ TẠI CÁC NƯỚC CHÂU Á............ 123

5.1. Cơ cấu phát triển và cách thức quản lý hệ thống tài chính cần linh hoạt, tăng khả năng cạnh tranh

5.2. Minh bạch thông tin trong hoạt động của hệ thống tài chính 126

5.3. Đảm bảo an toàn cho hệ thống tài chính 126

5.4. Chính sách tiền tệ linh hoạt 127

5.5. Phát triển khu vực tài chính đúng mực 128

5.6. Hiện đại hóa hệ thống tài chính 129

5.7. Nâng cao vai trò của các chủ thể tham gia hệ thống tài chính 130

5.8. Các ý kiến đề xuất khác 131

5.9. Hạn chế của đề tài và hướng nghiên cứu trong tương lai 133

DANH MỤC CÁC CÔNG TRÌNH ĐÃ CÔNG BỐ 135

TÀI LIỆU THAM KHẢO. 136 


\section{DANH MỤC TÙ VIẾT TÁT}

ADB: $\quad$ Asian Development Bank

ARDL: $\quad$ Auto Regressive Distributed Lag

GDP: $\quad$ Gross Domestic Product

GNP: $\quad$ Gross National Product

GFDD: Global Financial Development Database

GMM: $\quad$ Generalized Method of Moments

IMF: $\quad$ International Monetary Fund

WDI: $\quad$ World Development Indicators

WGI: World Governance Indicators

UNDP: Chương trình Phát triển Liên Hiệp Quốc

UAE: Các Tiểu vương quốc Ả Rập Thống Nhất

2SLS: $\quad$ 2-Stage Least Squares 


\section{DANH MỤC BẢNG}

Bảng 2.1 Tóm lược các lý thuyết về tăng trưởng kinh tế........................................31

Bảng 3.1 Phân loại các nước trong mẫu theo thu nhập........................................60

Bảng 3.2 Tóm tắt các biến số trong mô hình nghiên cứu ........................................71

Bảng 4.1 Thống kê mô tả toàn mẫu ................................................................... 81

Bảng 4.2 Thống kê các chỉ tiêu Phát triển tài chính toàn mẫu..................................82

Bảng 4.3 Ma trận tương quan giữa các biến trong mô hình nghiên cứu...................84

Bảng 4.4 Kết quả hồi quy ngưỡng với FD đo lường bằng Tín dụng cho khu vực tư

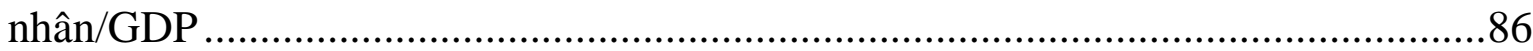

Bảng 4.5 Kiểm định sự tồn tại của ngưỡng khi FD =Tín dụng cho khu vực tư nhân/GDP

Bảng 4.6 Kiểm định sự tồn tại của ngưỡng khi FD =Tín dụng trong nước /GDP....92

Bảng 4.7 Kết quả hồi quy ngưỡng với FD = Tín dụng trong nước /GDP ................93

Bảng 4.8 Kiểm định sự tồn tại của ngưỡng khi FD = Nợ thanh khoản /GDP ..........94

Bảng 4.9 Kết quả hồi quy ngưỡng với FD = Cung tiền M3 /GDP .........................95

Bảng 4.10 Tóm tắt kết quả hồi quy ngưỡng (bank-based).....................................97

Bảng 4.11 Kết quả hồi quy ngưỡng với nguồn vốn con người đo bằng HDI ...........98

Bảng 4.12 Giá trị ngưỡng của Phát triển tài chính (bank-based) .............................99

Bảng 4.13 Kết quả system-GMM (bank-based) ..............................................101

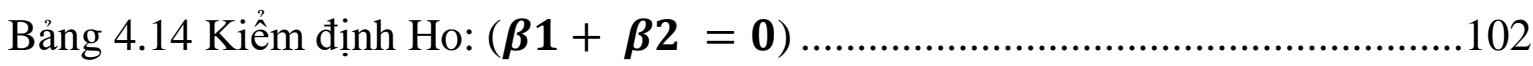

Bảng 4.15 Kiểm định giá trị ngưỡng khi FD= quy mô vốn hóa TTCK/GDP ........103

Bảng 4.16 Kết quả hồi quy ngưỡng $\mathrm{FD}=$ Tỷ số quy mô vốn hóa TTCK/GDP .....104

Bảng 4.17 Kết quả hồi quy ngưỡng $\mathrm{FD}=\mathrm{Tỷ}$ suất sinh lợi của TTCK ...................106

Bảng 4.18 Kiểm định giá trị ngưỡng khi FD = Tỷ suất sinh lợi của TTCK ...........107

Bảng 4.19 Kiểm định giá trị ngưỡng khi FD = Quy mô giao dịch của TTCK /GDP

Bảng 4.20 Kết quả hồi quy ngưỡng FD = Quy mô giao dịch của TTCK/GDP ......108 
Bảng 4.21 Tóm tắt kết quả hồi quy ngưỡng với FD đo bằng dữ liệu TTCK...........109

Bảng 4.22 Tóm tắt giá trị ngưỡng của Phát triển tài chính (market-based).............110

Bảng 4.23 Kết quả GMM trên dữ liệu TTCK.......................................................111

Bảng 4.24 Thống kê mô tả mẫu High income …………………………………...113

Bảng 4.25 Thống kê mô tả mẫu Middle income..................................................114

Bảng 4.26 Kết quả hồi quy ngưỡng mẫu phụ High income....................................115

Bảng 4.27 Kiểm định sự tồn tại của ngưỡng trong mẫu phụ High income .............117

Bảng 4.28 Kết quả hồi quy ngưỡng mẫu phụ Middle income ..................................118

Bảng 4.29 Kiểm định sự tồn tại của ngưỡng trong mẫu phụ Middle income.........119

Bảng 4.30 Ngưỡng của Phát triển tài chính trong mẫu phụ và toàn mẫu .................120 


\section{DANH MỤC HÌNH}

Hình 1.1 Tốc độ tăng trưởng GDP của các nước châu Á ………................................5

Hình 2.1 Bộ chỉ số FD đo lường phát triển tài chính của IMF ................................29

Hình 4.1 Đồ thị Quy mô vốn hóa TTCK các nước châu Á so với GDP năm 2016...... 


\section{PHÁT TRIỀN TÀI CHÍNH VÀ TĂNG TRƯởNG KINH TẾ}

\section{TÓM TẮT}

Tác động của sự phát triển tài chính lên tăng trưởng kinh tế quốc gia là chủ đề thu hút nhiều sự quan tâm và tranh luận không chỉ trong giới học thuật mà cả ở các nhà hoạch định chính sách. Nhiều quan điểm khác nhau, thậm chí là trái chiều nhau, trong việc đánh giá vai trò của phát triển tài chính đối với tăng trưởng kinh tế. Sau khủng hoảng 2008, Quỹ tiền tệ quốc tế đã cảnh báo rằng phát triển tài chính chỉ nên đạt đến một mức ngưỡng mà nếu vượt qua sẽ gây cản trở và làm giảm tăng trưởng. Nghiên cứu này phân tích tác động của sự phát triển tài chính đến tăng trưởng kinh tế tại các quốc gia châu Á, trên cơ sở đó xác định mức độ phát triển của hệ thống tài chính trong nền kinh tế để thúc đẩy sự tăng trưởng kinh tế trong dài hạn.

Bằng phương pháp hồi quy ngưỡng, kết hợp phương pháp ước lượng hồi quy GMM trên dữ liệu bảng của 33 quốc gia châu Á giai đoạn 2004-2016, kết quả của luận án tìm thấy rằng khi phát triển tài chính vượt qua giá trị ngưỡng, tác động của nó lên tăng trưởng kinh tế biến chuyển từ tích cực sang tiêu cực, phản ánh mối quan hệ là phi tuyến. Kết quả này hàm ý rằng phát triển tài chính ở mức độ cao không phải luôn luôn có lợi cho nền kinh tế. Trên cơ sở kết quả, luận án đề xuất các giải pháp cho các nước châu Á với kỳ vọng làm rõ thêm cho học thuật và đóng góp ý kiến cho các nhà hoạch định chính sách.

Tù khóa: Phát triển tài chính, tăng trưởng kinh tế, quan hệ phi tuyến 


\title{
FINANCIAL DEVELOPMENT AND ECONOMIC GROWTH
}

\begin{abstract}
The impact of financial development on national economic growth is a topic that attracts much interest and debate not only in academic researchers but also in policy-makers. Different perspectives, even conflicting, in assessing the role of financial development in economic growth. After the 2008 Crisis, the International Monetary Fund has warned that financial development should only reach a threshold that, if overcome, will hinder and reduce growth. This study provides a new empirical evidence of long-run effect of financial development on economic growth in a panel of 33 Asian countries (including Vietnam) in the period of 2004-2016. By threshold regression for panel data and Generalized Method of Moments (GMM), the results show that the relationship of financial development and economic growth is nonlinear. Financial development exerts a strong positive effect on growth only when it has achieved a threshold of financial development; beyond this turning point financial development will negatively impact on growth. This implies that high level of financial development does not always beneficial for national economic growth. Nowadays, an optiomal level of financial development which fosters sustainable growth should be taken into consideration for those countries.
\end{abstract}

Keywords: Financial development, Economic growth, nonlinear relationship 


\section{CHƯONG 1 \\ MỞ ĐẦU}

\subsection{Bối cảnh nghiên cứu của luận án}

Tăng trưởng kinh tế luôn được xem là một trong những mối quan tâm hàng đầu của các quốc gia trên thế giới. Chính vì lẽ đó, trong suốt một khoảng thời gian dài, các nhà kinh tế học trên thế giới đã tranh luận để tìm kiếm câu trả lời cho vấn đề là "tại sao một số quốc gia giàu có trong khi các quốc gia khác lại nghèo hơn”, "tại sao lại có sự khác nhau trong quá trình tăng trưởng kinh tế giữa các quốc gia”, “nguyên nhân chính của sự khác biệt đó là gì?” Để trả lời cho các câu hỏi này, từ thế kỷ 18 , nhiều nghiên cứu lý thuyết cũng như thực nghiệm đã được thực hiện và cho thấy rằng sự phát triển của hệ thống tài chính quốc gia giữ vai trò quan trọng và là một trong những yếu tố cơ bản tạo ra sự khác biệt về tăng trưởng kinh tế ở các nước (Levine, 1997). Vì thế, tác động của phát triển tài chính lên tăng trưởng kinh tế nhận được nhiều sự quan tâm của các học giả cũng như các nhà hoạch định chính sách quốc gia. Đặc biệt, đến những năm 80 của thế kỷ 20 với sự ra đời của lý thuyết tăng trưởng kinh tế nội sinh thì vấn đề về ảnh hưởng của sự phát triển tài chính lên tăng trưởng kinh tế một lần nữa thu hút mạnh mẽ sự chú ý của các nhà nghiên cứu. Từ đó xuất hiện nhiều quan điểm khác nhau, thậm chí là trái chiều nhau, trong việc đánh giá vai trò của phát triển tài chính đối với tăng trưởng kinh tế.

Trước đây với rất nhiều lý thuyết và bằng chứng thực nghiệm ủng hộ, người ta tin tưởng rằng hệ thống tài chính càng phát triển thì càng thúc đẩy tăng trưởng kinh tế. Đây là nhóm quan điểm nhận được nhiều sự đồng thuận của các nhà nghiên cứu từ trước cho đến thời gian gần đây. Schumpeter (1911) đã chỉ ra rằng hệ thống ngân hàng khi thực hiện tốt các chức năng của nó sẽ là một nhân tố quan trọng đối với quá trình tăng trưởng kinh tế do vai trò của nó trong việc huy động tiết kiệm, khuyến khích đổi mới sáng tạo công nghệ, và tài trợ cho các khoản đầu tư một cách hiệu quả. Nhiều học giả và các công trình nghiên cứu tiếp nối sau đó cũng ủng hộ ý tưởng nói 
trên như Gurley và Shaw (1955); McKinnon (1973), Shaw (1973), King và Levine (1993a, b), Levine (1997, 2003), Rajan và Zingales (1998), Levine và cộng sự (2000), Beck và Levine (2004), Beck và cộng sự (2000, 2005).

Bên cạnh quan điểm về tác động tích cực của phát triển tài chính lên tăng trưởng kinh tế thì cũng xuất hiện luồng quan điểm ngược lại như Lucas (1988) tuyên bố rằng các nhà kinh tế học đang đề cao thái quá vai trò của các nhân tố tài chính lên tăng trưởng kinh tế, thậm chí một số tác giả còn cho rằng sự phát triển tài chính gây ra tác động tiêu cực và cản trở đối với tăng trưởng kinh tế, hoặc cho rằng không đủ bằng chứng để xác nhận tác động tích cực của nhân tố này đến tăng trưởng như Chandavarkar (1992), Shan và cộng sự (2001), Khan và Senhadji (2003), Anderson và Tarp (2003).

Hơn thế nữa, cuộc khủng hoảng kinh tế toàn cầu 2008 đã buộc cả giới nghiên cứu lẫn các nhà hoạch định chính sách thực tiễn phải cân nhắc lại kết luận trước đây của họ. Cuộc khủng hoảng này là minh chứng cho thấy khả năng hệ thống tài chính hoạt động sai lệch sẽ trực tiếp và gián tiếp làm lãng phí nguồn lực quốc gia như thế nào. Sau cuộc khủng hoảng này, các chuyên gia của Quỹ tiền tệ quốc tế (IMF) đã cảnh báo rằng phát triển tài chính chỉ nên đạt đến một mức tối ưu, vượt qua mức này nó có thể sẽ gây tác động cản trở tăng trưởng kinh tế, (Cecchetti và Kharroubi, 2012; Arcand và cộng sự, 2012). Vì thế, tác động của sự phát triển hệ thống tài chính lên tăng trưởng kinh tế là tích cực hay tiêu cực là vấn đề cần phải xem xét lại để có câu trả lời xác đáng hơn.

Từ những động lực phân tích ở trên, các học giả đã chú ý nghiên cứu nhiều hơn về mối quan hệ và tác động của sự phát triển tài chính lên tăng trưởng kinh tế. Rioja và Valev (2004a) nghiên cứu trên dữ liệu bảng mẫu gồm 74 quốc gia phát triển và đang phát triển giai đoạn từ năm 1961 đến 1995 với dữ liệu tính trung bình theo chu kỳ 5 năm. Hai tác giả này đã tìm thấy rằng phát triển tài chính tạo ra tác động tích cực lên tăng trưởng kinh tế chỉ khi nào nó đạt đến một mức độ nào đó, gọi là ngưỡng phát triển tài chính, mà dưới mức này thì tác động lại không chắc là tốt. Các 
nhà nghiên cứu này hàm ý rằng bản thân hệ thống tài chính phải phát triển lớn mạnh trước thì nó mới có thể tạo ra ảnh hưởng tốt thúc đẩy cho tăng trưởng kinh tế. Tuy nhiên, họ cũng phân tích cho thấy rằng đối với các quốc gia có mức độ phát triển tài chính trung bình thì sự lớn mạnh của hệ thống tài chính có tác động tích cực đáng kể lên tăng trưởng kinh tế; trong khi ở các nước đã có mức độ phát triển tài chính cao thì sự tác động này vẫn là tích cực nhưng mức độ ảnh hưởng thấp hơn; trái lại, đối với các nước có mức độ phát triển tài chính thấp thì vai trò thúc đẩy tăng trưởng kinh tế của hệ thống tài chính lại không đạt ý nghĩa thống kê. Như vậy là, mức độ phát triển tài chính giữ một vai trò quan trọng trong việc định hình ảnh hưởng của nó lên tăng trưởng kinh tế. Từ kết quả nghiên cứu này có thể thấy, mặc dù thể hiện tác động tích cực đến tăng trưởng của nền kinh tế nhưng sự tác động của phát triển tài chính tại các quốc gia thì không giống nhau. Sự khác biệt về tác động thì phụ thuộc theo trình độ phát triển của nền kinh tế, nước đã phát triển cao khác với nước đang phát triển.

Sự đổi chiều tác động của phát triển tài chính lên tăng trưởng kinh tế cũng được tìm thấy ở nhiều nghiên cứu sau đó như nghiên cứu của Shen và Lee (2006), Ergungor (2008), Huang và Lin (2009), Law, Azman-Saini, và Ibrahim (2013) nhưng vấn đề nảy sinh ở đây chính là sự mâu thuẫn trong các kết luận tìm thấy. Khác với Rioja và Valev (2004a) cho rằng bản thân hệ thống tài chính phải vượt qua giá trị ngưỡng thì mới có tác động thúc đẩy cho tăng trưởng kinh tế, Shen và Lee (2006) kết luận rằng mối quan hệ phi tuyến giữa phát triển tài chính và tăng trưởng kinh tế có dạng chữ U ngược, nghĩa là trước giá trị ngưỡng thì phát triển tài chính có vai trò tích cực lên tăng trưởng kinh tế nhưng mức độ phát triển của hệ thống tài chính vượt cao qua giá trị ngưỡng giới hạn của nó lại gây tác động cản trở lên tăng trưởng. Lập luận của hai nhà nghiên cứu này tương đồng với các nghiên cứu sau đó của Cecchetti và Kharroubi (2012), Arcand và cộng sự (2012), Law và Singh (2014), Samargandi và cộng sự (2015). Tuy nhiên, Shen và Lee (2006) cũng thừa nhận mối quan hệ phi tuyến dạng chữ U ngược này thì yếu về mặt ý nghĩa thống kê. Trong khi đó, Loayza và Ranciere (2006) không đồng thuận với giả thuyết rằng có một tác động không đơn 


\section{Trang 4}

điệu của độ sâu tài chính (là một trong những khía cạnh thể hiện mức độ phát triển tài chính) lên tăng trưởng kinh tế.

Đối với các nước châu Á, số lượng các nghiên cứu thực nghiệm về chủ đề này được công bố chính thức khá ít ỏi nhưng cũng đã thu hút sự quan tâm của các nhà nghiên cứu như Jeanneney và cộng sự (2006), Ang (2009), Wong và Zhou (2010), tuy vậy mẫu của các nghiên cứu này không phản ánh đầy đủ được đặc tính của các nước châu Á giai đoạn sau khủng hoảng 2008 do số lượng nước tiếp cận được dữ liệu bị hạn chế, đơn cử như mẫu của Wong và Zhou (2010) so sánh 3 nước châu Á là Hong Kong, China, Nhật Bản với hai nền kinh tế Mỹ và Anh thời kỳ trước khủng hoảng (1988-2008); hay Iyare và Moore (2011) nghiên cứu với mẫu 5 quốc gia thì cũng chỉ có 1 nước châu Á là Singapore. Hsueh và cộng sự (2013) phân tích mối quan hệ nhân quả giữa tăng trưởng kinh tế và phát triển tài chính nhưng mẫu cũng chỉ có 10 quốc gia châu Á (không có Việt Nam) và chỉ giới hạn trong giai đoạn 1980-2007, tức là trước khủng hoảng kinh tế toàn cầu, với bối cảnh kinh tế - chính trị khác biệt nhiều so với hiện nay. Law và Singh (2014) nghiên cứu 87 nền kinh tế đã phát triển và đang phát triển trên thế giới trong giai đoạn 1980-2010; tuy nhiên châu Á cũng chỉ có 8 quốc gia được đưa vào nghiên cứu này gồm Hongkong, India, Indonesia, Japan, Malaysia, Phillipines, Singapore, Thailand trong khi đó Trung Quốc, Việt Nam, và các nền kinh tế châu Á khác không được xem xét.

Từ bối cảnh nghiên cứu này đã dẫn đến khoảng trống nghiên cứu và vấn đề nghiên cứu của luận án, được trình bày trong phần tiếp theo.

\subsection{Khoảng trống nghiên cứu}

Có thể thấy, quan điểm của các nhà nghiên cứu về vai trò và ảnh hưởng của phát triển tài chính lên tăng trưởng kinh tế không thống nhất với nhau mà có sự mâu thuẫn trong các kết luận. Thậm chí, giữa các chuyên gia về tài chính thế giới cũng không đồng quan điểm về hướng phát triển cần thiết cho hệ thống tài chính của các nước châu Á. Trong khi các chuyên gia IMF từ năm 2012 đã cảnh báo về rủi ro tiềm ẩn cho nền kinh tế nếu phát triển tài chính quá nhiều thì hiện nay trên website chính 
thức của tổ chức Ngân hàng Phát triển châu Á (ADB) vẫn đưa ra khuyến nghị cho các nước châu Á phải tăng cường phát triển tài chính bởi vì kết quả thực nghiệm mà các chuyên gia này dẫn chứng cho thấy phát triển tài chính của các nước châu Á vẫn còn thấp đáng kể so với châu Âu và Mỹ, và phát triển tài chính có vai trò tích cực và tương quan dương với tăng trưởng kinh tế. Vậy đâu mới thực sự là hướng đi đúng đắn cho các nền kinh tế châu Á?

Bối cảnh kinh tế - chính trị của thế giới sau khủng hoảng 2008 có nhiều biến động và khác biệt so với giai đoạn trước đó, đặt ra vấn đề cho chính phủ các nước cũng như các nhà nghiên cứu kinh tế cần phải nhìn nhận lại, đánh giá lại vai trò của phát triển tài chính lên tăng trưởng.

Đối với khu vực châu Á, mặc dù có nhiều nền kinh tế mới nổi có tốc độ tăng trưởng cao và thu hút nhiều sự quan tâm của giới đầu tư nhưng trong các nghiên cứu đã có thời gian vừa qua thì châu lục này chưa thực sự được đưa vào nghiên cứu đúng mức và đầy đủ. Đặc biệt là qua phân tích thực tiễn trong thời gian gần đây cho thấy tốc độ tăng trưởng của các nước trong khu vực châu Á đang có xu hướng giảm.

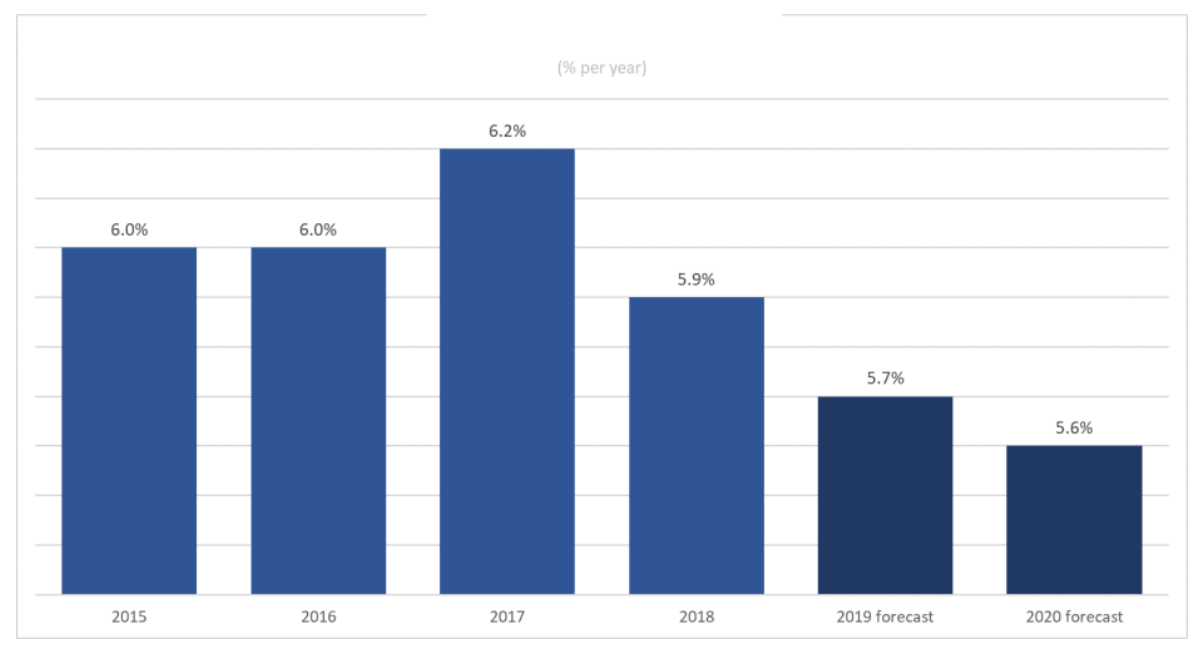

\section{Hình 1.1 Tốc độ tăng trưởng GDP của các nước châu Á}

Nguồn: $A D B$

Theo dự báo của IMF, trong vòng ba thập kỷ tới, xu hướng sụt giảm tăng trưởng này của các quốc gia châu Á sẽ ngày càng nghiêm trọng hơn, điều này cũng 
đặt ra vấn đề là các nền kinh tế châu Á cần có đối sách gì cho phù hợp để có thể duy trì mức tăng trưởng kinh tế trong dài hạn, liên quan đến chính sách phát triển hệ thống tài chính quốc gia, là một trong những vấn đề quan trọng của chính sách tăng trưởng kinh tế. Liệu các kết luận tìm thấy từ những nghiên cứu trước đó về các nước châu Âu có phù hợp để áp dụng tại các nước châu Á, với đặc thù nhiều khác biệt hay không.

Ngoài ra, trước đây chưa có nghiên cứu chính thức nào được thực hiện phối hợp đầy đủ cả hai phương diện của phát triển tài chính là: sự phát triển của khu vực ngân hàng và sự phát triển của thị trường chứng khoán.

Các khoảng trống trong nghiên cứu nói trên đã dẫn đến nhu cầu cần thiết làm sáng tỏ tác động thực sự của phát triển tài chính lên tăng trưởng kinh tế với mẫu dành cho các quốc gia châu Á, xem xét cả nhân tố thu nhập và những đặc thù của các nền kinh tế mới nổi và đang phát triển. Đây cũng chính là động lực để tác giả thực hiện luận án này với kỳ vọng đóng góp thêm cho học thuật những hiểu biết rõ nét hơn về các nền kinh tế châu Á trong bối cảnh mới của thế giới.

\subsection{Vấn đề nghiên cứu và mục tiêu nghiên cứu}

Bối cảnh nghiên cứu và tình hình kinh tế thực tiễn của các nước châu Á đã dẫn đến nhu cầu cần thiết tìm ra câu trả lời mà hầu hết các quốc gia quan tâm là làm sao để tăng trưởng kinh tế và duy trì điều đó trong dài hạn. Trên cơ sở khoảng trống nghiên cứu đã trình bày ở mục 1.2 , vấn đề nghiên cứu của luận án được xác định là: sự phát triển của hệ thống tài chính và tăng trưởng kinh tế tại châu Á.

Mục tiêu nghiên cứu của luận án là kiểm định tác động của sự phát triển tài chính lên tăng trưởng kinh tế tại các quốc gia châu Á, từ đó đề xuất các giải pháp định hướng phát triển hệ thống tài chính cho các quốc gia châu Á, hướng tới duy trì sự tăng trưởng kinh tế trong dài hạn.

Để thực hiện mục tiêu nghiên cứu nói trên, các mục tiêu cụ thể bao gồm:

$\checkmark$ Xác định giá trị ngưỡng của mức độ phát triển tài chính trong mối quan hệ giữa phát triển tài chính và tăng trưởng kinh tế. (Giá trị ngưỡng là giá trị mà 
trước và sau giá trị này thì tác động của phát triển tài chính lên tăng trưởng kinh tế có sự thay đổi).

$\checkmark$ Kiểm định tác động của phát triển tài chính lên tăng trưởng kinh tế cụ thể như thế nào.

$\checkmark$ Từ kết quả nghiên cứu, đề xuất các gợi ý chính sách về phát triển hệ thống tài chính cho các nền kinh tế châu Á.

Trên cơ sở các mục tiêu cụ thể này, kết hợp với lược khảo các tài liệu nghiên cứu trước, các câu hỏi nghiên cứu và giả thuyết nghiên cứu được xây dựng và trình bày chi tiết trong chương 3 .

\section{4. Đối tượng và phạm vi nghiên cứu}

Về mặt địa lý, châu Á gồm 50 nước được đưa vào xem xét, sau đó loại trừ dần các nước không cung cấp đầy đủ thông tin, còn lại 33 quốc gia châu Á được đưa vào mẫu nghiên cứu trong giai đoạn 2004-2016 của luận án này để phân tích về tác động của sự phát triển tài chính lên tăng trưởng kinh tế. Các nhân tố nào ảnh hưởng đến phát triển tài chính không thuộc phạm vi của nghiên cứu này.

Năm 2016 được cân nhắc lựa chọn để có thể quan sát được số quốc gia châu Á nhiều nhất có thể tiếp cận dữ liệu. Hơn nữa, nguồn dữ liệu chính thống mà nghiên cứu này sử dụng là bộ dữ liệu Global Financial Development Data của Ngân hàng Thế giới (World Bank) để đo lường một trong các biến chính của bài nghiên cứu là Tỷ số Nợ thanh khoản trên GDP (Liquid liabilities to GDP) cho đến nay cũng chỉ có dữ liệu đến năm 2016. Đây là lý do khách quan khiến cho khung thời gian nghiên cứu chỉ đến năm 2016. Ngoài ra, phần lớn các nước trong mẫu nghiên cứu này là các nền kinh tế còn non trẻ và đang phát triển. Vì thế, trước năm 2004, dữ liệu về hệ thống tài chính của họ không được ghi nhận đầy đủ, hoặc họ chưa phát triển thị trường.

Bên cạnh đó, khoảng thời gian phân tích 2004-2016 được lựa chọn bởi vì trước năm 2008, không chỉ các nhà kinh tế học mà ngay cả các nhà hoạch định chính sách của các chính phủ đều tin tưởng rằng hệ thống tài chính phát triển mạnh mẽ sẽ là một 
tiền đề không thể thiếu nếu muốn đạt được tăng trưởng của nền kinh tế. Các số liệu thống kê đã chỉ ra rằng, độ phát triển tài chính của các nước châu Á tuy diễn ra mạnh mẽ nhưng vẫn còn thấp so với các nền kinh tế đã phát triển (Sahay và cộng sự, 2015). Điều này hàm ý rằng các quốc gia châu Á vẫn đang mong đợi hệ thống tài chính của họ phát triển thêm nữa để thúc đẩy tăng trưởng kinh tế. Thế nhưng biến cố khủng hoảng 2008 lại xuất phát ngay từ chính những nền kinh tế mạnh và có hệ thống tài chính đã phát triển đến độ phức tạp là Mỹ, sau đó lan rộng ra toàn cầu, ảnh hưởng nghiêm trọng đến cả các quốc gia châu Á. Cuộc khủng hoảng này đã gióng lên tiếng chuông cảnh báo nhưng chưa có đủ bằng chứng thực nghiệm rằng hệ thống tài chính phát triển quá cao, quá nhiều sẽ có thể gây ra rủi ro và tổn thương cho nền kinh tế. Vì thế, tác giả luận án này lựa chọn khung thời gian nghiên cứu từ 2004-2016 trải dài từ trước, trong, đến sau khủng hoảng 2008 để phân tích đánh giá, với kỳ vọng là có thể rút ra bài học kinh nghiệm và hướng phát triển phù hợp cho các nước châu Á.

Đối tượng nghiên cứu là tăng trưởng kinh tế và phát triển hệ thống tài chính tại 33 quốc gia. Số liệu về các nước trong mẫu được đánh giá trên cả hai phương diện: dựa trên số liệu của khu vực ngân hàng, và dựa trên số liệu của thị trường chứng khoán. Tuy nhiên, khi phân tích về mức độ phát triển tài chính trên phương diện thị trường tài chính, mẫu phải loại trừ trường hợp Brunei, Maldives, Cambodia, Myanmar, Taijikistan vì các quốc gia này không có thị trường chứng khoán; và loại trừ Armenia, Bangladesh, Kuwait, Kyrgyz Republic, Nepal, Mongolia do không có dữ liệu từ năm 2013-2016. Vì thế các phân tích dựa trên số liệu thị trường chứng khoán chỉ còn 22 quốc gia trong giai đoạn 2004-2016.

\subsection{Phương pháp nghiên cứu}

Dữ liệu bảng được sử dụng trong phân tích của luận án này vì ưu điểm kết hợp được cả hai chiều không gian và thời gian. Luận án phân tích định lượng mối quan hệ phi tuyến giữa phát triển tài chính và tăng trưởng kinh tế, dùng phương pháp ước lượng Hồi quy Ngưỡng cho dữ liệu bảng (Panel Threshold Regression) đề xuất ban đầu bởi Hansen (1999), sau đó Wang (2015) phát triển trên phần mềm Stata thành 
Mô hình Hồi quy Ngưỡng với Fixed Effect trên dữ liệu bảng (Fixed Effect Panel Threshold Model). Phương pháp này đòi hỏi dữ liệu phải là dạng bảng cân bằng (balanced panel).

Mô hình nghiên cứu kế thừa từ mô hình cơ bản của King và Levine (1993 a,b) kết hợp với phương trình hồi quy ngưỡng kế thừa từ nghiên cứu của Law và Singh (2014), trong đó biến giải thích FD - đại diện cho sự phát triển tài chính - tác động đến biến phụ thuộc GROWTH - đại diện cho tăng trưởng kinh tế, cùng với các biến kiểm soát là: pop (đại diện cho nhân tố Lao động), income (phản ánh GDP bình quân đầu người). Biến income đại diện cho nhân tố thu nhập có xét độ trễ một năm, tức là

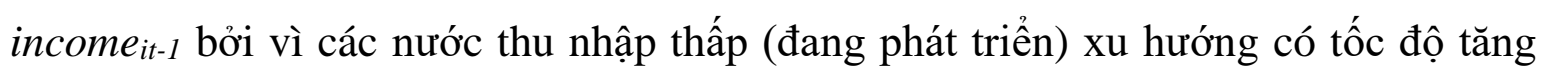
trưởng trung bình cao hơn so với các nước thu nhập cao nhưng tác động này có độ trễ, tức là thu nhập bình quân đầu người năm trước tác động đến tốc độ tăng GDP năm nay. Ngoài ra còn có biến invest (đại diện cho nhân tố Đầu tư), mys (phản ánh nguồn vốn con người, đo lường qua số năm đi học trung bình của người dân). Chi tiết về mô hình nghiên cứu được trình bày trong chương 3 .

Phương trình hồi quy ngưỡng bổ sung thêm vào phương trình phân tích hồi quy cơ bản một hàm chỉ mục. Hàm chỉ mục này sẽ chia tác động của biến giải thích lên biến phụ thuộc thành 2 miền tác động (regime) khác nhau, chúng phân biệt với nhau bởi hệ số tương quan khác nhau là $\beta_{1}$ và $\beta_{2}$. Nhờ đó, có thể nắm bắt được tác động thay đổi của biến giải thích FD khi vượt qua giá trị ngưỡng, đồng thời xác định rõ được giá trị của ngưỡng là bao nhiêu.

Phương pháp của Hansen (1999) là một phương pháp ước lượng đơn giản nhưng xác định cụ thể giá trị của ngưỡng và phản ánh mối quan hệ phi tuyến, khi vượt qua điểm chuyển tiếp thì tác động có sự thay đổi.

Để củng cố cho tính vững của kết quả ước lượng được, luận án thực hiện lần lượt thêm các biến giải thích khác vào mô hình hồi quy, bao gồm biến tradeop đại diện cho độ mở thương mại, biến infla đại diện cho yếu tố lạm phát trong nền kinh tế, biến inst phản ánh đánh giá về nhân tố thể chế, và biến goexp đại diện cho chi tiêu 
chính phủ (theo Law và Singh, 2014) để xem xét các giá trị ngưỡng và hệ số tương quan tìm được.

Các biện pháp khác nhằm kiểm tra tính vững của kết quả tìm được cũng được thực hiện trong luận án này bao gồm:

- Thay thế cách đo lường biến số: Biến giải thích chính trong mô hình nghiên cứu là biến $\mathrm{FD}$, đại diện cho sự phát triển tài chính, lần lượt được ước lượng hồi quy theo 6 cách đo lường khác nhau: Tỷ số tín dụng cho khu vực tư nhân trên GDP; Tỷ số tín dụng trong nước trên GDP; Tỷ số Nợ thanh khoản trên GDP (Law và Singh, 2014); Tỷ số Quy mô vốn hóa thị trường chứng khoán trên GDP; Tỷ số sinh lợi của thị trường chứng khoán; Tổng giá trị giao dịch của TTCK trên GDP (Cihak và cộng sự, 2012).

- Phân tích trên mẫu phụ (sub-sample): chia mẫu nghiên cứu thành hai mẫu phụ theo thu nhập để kiểm định lại kết quả, dựa trên Tiêu chuẩn phân nhóm quốc gia theo GNI bình quân đầu người của World Bank gần đây nhất là năm 2017, được tính từ đơn vị nội tệ chuyển đổi sang đô-la Mỹ (xin xem chi tiết tại trang 60 , chương 3). Thu nhập GDP bình quân đầu người là một nhân tố quan trọng thể hiện trình độ phát triển của nền kinh tế. Theo các kết quả nghiên cứu trước, tác động của phát triển tài chính đến tăng trưởng kinh tế không giống nhau tại các nước có trình độ phát triển kinh tế khác nhau (Rioja và Valev, 2004b). Việc phân chia ra hai mẫu phụ có hai mục đích: thứ nhất là bổ sung vào khoảng trống của các nghiên cứu trước đây, thứ hai là kiểm nghiệm các kết luận tìm thấy trong toàn mẫu đã được đề cập ở phần trên có khác biệt gì không khi bối cảnh các nước nghiên cứu khác biệt nhau về thu nhập. Nếu các kết quả là nhất quán trong toàn mẫu cũng như trong các mẫu phụ thì kết luận tìm thấy được gia tăng tính vững và độ tin cậy.

- Dùng phương pháp ước lượng thay thế khác: Biến giả được sử dụng để phân chia mẫu thành hai regime: các quan sát trên giá trị ngưỡng thì biến giả nhận giá trị $=1$; ngược lại thì biến giả nhận giá trị $=0$. Biến tương tác 
giữa biến giả và biến $\mathrm{FD}$ được đưa vào mô hình hồi quy, phương pháp System - GMM theo Arellano và Bond (1991) được sử dụng để ước lượng các hệ số hồi quy nhằm phân tích tác động của phát triển tài chính lên tăng trưởng kinh tế trước và sau điểm chuyển tiếp. Việc áp dụng phương pháp ước lượng GMM như là một phương pháp phân tích thay thế góp phần giải quyết các vấn đề có thể phát sinh trong hồi quy dữ liệu bảng như vấn đề nội sinh, phương sai thay đổi, và tự tương quan. Ngoài ra, việc sử dụng phương pháp GMM như là một phương pháp phân tích thay thế để trả lời cho cùng một vấn đề nghiên cứu cũng là một cách thức để xem xét kết quả nghiên cứu đạt được của luận án có nhất quán và vững hay không. Luận án cũng thực hiện kiểm định giả thuyết Ho: không có tác động của biến FD lên biến phu thuộc, khi FD vuợt qua giá trị nguoõng. Giả thuyết Ho này bị bác bỏ thì sự tồn tại của giá trị ngưỡng được xác nhận, hay nói cách khác là xác nhận có mối quan hệ phi tuyến giữa phát triển tài chính và tăng trưởng kinh tế.

\subsection{Tóm tắt kết quả nghiên cứu}

Kết quả phân tích định lượng của luận án cho thấy tại các quốc gia châu Á phát triển tài chính không chỉ tác động dương mà còn có thể gây ra tác động âm lên tăng trưởng của nền kinh tế tại các miền giá trị khác nhau của biến số đo lường sự phát triển tài chính. Nói cách khác, mối quan hệ giữa phát triển tài chính và tăng trưởng kinh tế là phi tuyến và xuất hiện giá trị ngưỡng của phát triển tài chính mà khi vượt qua ngưỡng này, tác động gây ra bởi phát triển tài chính thay đổi so với trước đó.

Kết quả thực nghiệm trên toàn mẫu đã xác nhận giá trị ngưỡng của phát triển tài chính dành cho các nước châu Á là: tín dụng dành cho khu vực tư nhân chiếm tỷ trọng 8,9762\% so với GDP; tín dụng trong nước chiếm 8,8641\% so với GDP, và cung tiền mở rộng M3 chỉ nên là 18,0957\% so với GDP. Khi xem xét khía cạnh thị trường, giá trị ngưỡng của quy mô vốn hóa TTCK là $81,8477 \%$ so với GDP, tỷ suất sinh lợi của TTCK là 27,3429\%, quy mô giao dịch của TTCK là 51,2688\% so với GDP. 
Khi phân tích trên dữ liệu của khu vực ngân hàng, kết quả nghiên cứu đều đạt ý nghĩa thống kê và cho thấy rằng: trong miền giá trị dưới ngưỡng, phát triển tài chính thể hiện vai trò thúc đẩy cho tăng trưởng kinh tế, tác động là tích cực; tuy nhiên trong miền giá trị mà phát triển tài chính vượt trên mức ngưỡng, nó lại thể hiện tác động tiêu cực. Tuy nhiên, khi phản ánh mức độ phát triển của thị trường tài chính thông qua các chỉ tiêu về TTCK thì trong miền giá trị dưới ngưỡng, phát triển tài chính thể hiện tác động dương; vượt trên mức ngưỡng, nó vẫn tiếp tục thể hiện tác động dương nhưng mức độ thúc đẩy cho nền kinh tế tăng trưởng bị sụt giảm.

Kết quả này hàm ý rằng các nước phát triển và đang phát triển châu Á vẫn có thể theo đuổi mục tiêu tăng trưởng kinh tế bằng cách đẩy mạnh phát triển tài chính để phát huy hiệu quả của nó lên nền kinh tế nhưng không phải cứ phát triển khu vực tài chính càng nhiều là càng tốt và luôn luôn tốt, mà các nhà hoạch định và điều hành chính sách phát triển quốc gia cần phải ý thức về một mức độ giới hạn trong phát triển tài chính.

\subsection{Những đóng góp của luận án}

Luận án đã đóng góp vào việc chi tiết hóa và bổ sung cho lý thuyết về tác động của phát triển hệ thống tài chính đến tăng trưởng kinh tế với trường hợp nghiên cứu về các quốc gia châu Á.

Trước khủng hoảng tài chính 2008, các nhà nghiên cứu về kinh tế mặc định rằng hệ thống tài chính và thị trường tài chính càng phát triển thì tăng trưởng kinh tế càng cao, hàm ý cổ súy thúc đẩy mở rộng và phát triển khu vực tài chính càng nhiều càng tốt bởi vì họ đánh giá rằng khu vực tài chính phát triển sẽ giúp cho vốn được phân bổ hiệu quả hơn. Điều này trở thành một nhân tố thiết yếu xuất hiện trong các mô hình nghiên cứu về tăng trưởng. Tuy nhiên, kết quả thực nghiệm của luận án này đã bổ sung thêm minh chứng xác thực rằng không phải cứ phát triển khu vực tài chính mạnh mẽ là tốt cho nền kinh tế, mà cần phải xác định giới hạn của việc mở rộng và phát triển tài chính thì mới đảm bảo được tăng trưởng kinh tế trong dài hạn. 
Hơn nữa, những nghiên cứu trước đây ít chú trọng đến các nước châu Á trong khi đây lại là khu vực tiềm năng và đang phát triển mạnh mẽ, rất cần được nghiên cứu. Vì vậy luận án này là nghiên cứu đầu tiên thực hiện với mẫu châu Á với số lượng quốc gia đầy đủ hơn, thực hiện phân nhóm theo thu nhập để so sánh, làm rõ tính chất khác biệt của mối quan hệ giữa nhóm nước có trình độ phát triển cao với nhóm nước còn lạc hậu, yếu kém và đang phát triển. Luận án cũng là nghiên cứu chính thức đầu tiên về châu Á kết hợp cả hai phương diện của hệ thống tài chính, đó là sự phát triển của hệ thống ngân hàng và sự phát triển của thị trường chứng khoán. Các nghiên cứu trước đây cùng chủ đề thường chỉ phân tích đơn lẻ dựa trên dữ liệu về ngân hàng, hoặc kết hợp dữ liệu nhưng phương pháp kết hợp chưa mang tính logic.

Thông qua kết quả nghiên cứu, luận án này còn là đóng góp về mặt lược khảo học thuật. Các trường phái nghiên cứu trước liên quan đến tăng trưởng và phát triển tài chính đã được hệ thống hóa một cách rõ ràng mạch lạc. Từ kết quả nghiên cứu tìm thấy, luận án có những đóng góp ý kiến về chính sách phát triển phù hợp với đặc thù của các nước châu Á. Vì vậy kết quả nghiên cứu của luận án cũng là tài liệu tham khảo hữu ích cho các nhà hoạch định chính sách kinh tế.

\subsection{Kết cấu của luận án}

Luận án được kết cấu thành 5 phần:

Chương 1- Mở đầu: tóm tắt để giới thiệu cơ bản về nghiên cứu của luận án

Chương 2 - Tổng quan lý thuyết và các nghiên cứu trước: trình bày chi tiết các lý thuyết và bằng chứng thực nghiệm trong các nghiên cứu trước đây, liên quan đến vấn đề nghiên cứu của luận án.

Chương 3 - Phương pháp nghiên cứu: trình bày chi tiết về các quốc gia trong mẫu nghiên cứu, lý do vì sao loại trừ một số nước ra khỏi mẫu, lý giải cho việc chọn lựa khung thời gian nghiên cứu và phương pháp kinh tế lượng lựa chọn để thực hiện, giải thích phương trình nghiên cứu và đo lường các biến số trong mô hình. 
Chương 4 - Kết quả nghiên cứu: thảo luận các kết quả ước lượng được bằng phân tích định lượng kết hợp với thực tiễn tại châu Á

Chương 5- Kết luận và Hàm ý chính sách: trên cơ sở kết quả nghiên cứu để đề xuất một số ý kiến về phát triển hệ thống tài chính quốc gia hướng đến thúc đẩy tăng trưởng kinh tế. 


\section{CHU'ONG 2 \\ TỔNG QUAN LÝ THUYÊT VÀ CÁC NGHIÊN CỨU TRƯỚC ĐÂY}

Trong suốt một khoảng thời gian dài từ thế kỷ 18 cho đến nay, các nhà kinh tế học trên thế giới luôn suy nghĩ và tìm kiếm câu trả lời cho vấn đề là tại sao một số quốc gia thì giàu có trong khi một số khác lại nghèo, tại sao nước này thành công về kinh tế hơn nước khác, tại sao quốc gia này tăng trưởng kinh tế nhanh hơn, còn quốc gia khác lại tăng trưởng chậm. Những câu hỏi trên luôn là những chủ đề hấp dẫn trong nghiên cứu. Adam Smith (1776) có thể được coi học giả đầu tiên đặt xuất phát điểm cho các lý thuyết tăng trưởng kinh tế khi ông đưa ra các quan điểm làm nền tảng cho nhiều nghiên cứu sau này về chủ đề tăng trưởng. Tiếp nối sau đó, các công trình nghiên cứu về tăng trưởng kinh tế với dữ liệu thu thập từ nhiều quốc gia đã liên tục được công bố, tuy nhiên đến giai đoạn sau chiến tranh Thế giới lần thứ hai, các nghiên cứu này được phân chia vào các lĩnh vực khác nhau: lý thuyết chính thống về tăng trưởng kinh tế trở thành một bộ phận của Kinh tế học vĩ mô; các nghiên cứu về các nước nghèo thì thuộc về lĩnh vực Kinh tế phát triển; còn nghiên cứu về làm thế nào để các quốc gia trở nên giàu có thì thuộc về Lịch sử kinh tế. Cho đến ba thập niên gần đây, tăng trưởng kinh tế mới xuất hiện trở lại như một lĩnh vực nghiên cứu độc lập (Weil, 2013). Các nhà nghiên cứu về kinh tế đã khám phá những cách thức mới để giải thích cho sự khác biệt về thu nhập của các quốc gia. Các công cụ phân tích mới về mặt lý thuyết, dữ liệu mới, cách thấu hiểu mới đã tạo ra sự pha trộn của các lý thuyết tăng trưởng mới và quan điểm truyền thống, làm cho chủ đề về tăng trưởng kinh tế một lần nữa thu hút nhiều sự chú ý của các nhà nghiên cứu. Vì vậy, để hiểu có chiều sâu về nghiên cứu này, phần tiếp theo sẽ trình bày các khái niệm cơ bản, định nghĩa quan trọng, tổng quan các nghiên cứu trước đây về chủ đề, để làm cơ sở lý luận và khung lý thuyết cho nghiên cứu của luận án này. 


\subsection{Tăng trưởng kinh tế}

Tăng trưởng kinh tế là sự gia tăng sản lượng hàng hóa và dịch vụ được sản xuất tính bình quân trên đầu người dân trong một khoảng thời gian nhất định. Sản lượng ở đây thường được đo bằng tổng sản phẩm quốc gia GNP (Gross National Product) hoặc tổng sản phẩm quốc nội GDP (Gross Domestic Product). Vì vậy tăng trưởng kinh tế còn được hiểu là sự gia tăng của GDP hoặc GNP, hoặc tăng thu nhập bình quân đầu người. Dù theo định nghĩa nào thì tăng trưởng kinh tế cần phải được hiểu là một quá trình thay đổi về lượng của nền kinh tế, tạo ra sản lượng thực cao hơn. Mặt khác, tăng trưởng kinh tế không chỉ là quá trình làm ra cùng một thứ nhiều hơn mà còn là quá trình thay đổi cơ cấu sản xuất và tiêu dùng cả về số lượng lẫn chất lượng. Sản lượng ở đây được hiểu một cách đầy đủ bao gồm hàng hóa và dịch vụ mà mọi cá nhân trong xã hội được thụ hưởng (Nguyễn Trọng Hoài, 2007).

\subsubsection{Phân biệt Tăng trưởng kinh tế và Phát triển kinh tế}

Tăng trưởng kinh tế là điều kiện cần nhưng không phải điều kiện đủ của phát triển kinh tế. Hai khái niệm này dễ bị nhầm lẫn và cần được phân biệt rõ. Phát triển kinh tế mang nội hàm rộng hơn tăng trưởng kinh tế, bao gồm tăng trưởng kinh tế kèm theo những thay đổi trong phân phối sản phẩm đầu ra và cấu trúc nền kinh tế. Những thay đổi này bao gồm sự chuyển dịch cơ cấu kinh tế, giảm tỷ lệ sản phẩm nông nghiệp đồng thời tăng tỷ lệ sản phẩm công nghiệp và dịch vụ trong GNP, hoặc tăng phúc lợi xã hội, tuổi thọ, thể chất, kỹ năng của người lao động,... Phát triển kinh tế là một quá trình hoàn thiện về mọi mặt của nền kinh tế bao gồm kinh tế, xã hội, môi trường, thể chế trong một thời gian nhất định nhằm đảm bảo rằng GDP cao hơn đồng nghĩa với mức độ hạnh phúc hơn.

\subsubsection{Hàm sản xuất}

Đầu thế kỷ XX, các nhà kinh tế học cho rằng có thể dự báo được sản lượng của một nền kinh tế thông qua một hàm sản xuất với các yếu tố đầu vào như đất đai, lao động, vốn. Hàm sản xuất có thể biểu diễn mối quan hệ giữa yếu tố đầu vào và yếu tố đầu ra, được biểu diễn một cách tổng quát như sau: 


$$
Y=f(K, L)
$$

Với $Y$ là tổng sản lượng, $\mathrm{K}$ là vốn, $\mathrm{L}$ là lao động. Hàm $\mathrm{F}$ xác định chính xác sản lượng đầu ra $\mathrm{Y}$ vừa cho thấy mức độ thay đổi của $\mathrm{K}$ và $\mathrm{L}$, đây chính là điểm phân biệt nhiều mô hình tăng trưởng khác nhau.

\subsection{3. Đo lường tăng trưởng kinh tế}

Tăng trưởng kinh tế là tăng trong thu nhập quốc gia. Vì vậy, hai chỉ số cơ bản dùng để đo lường tăng trưởng kinh tế là GDP và GNP. Để đo lường tăng trưởng kinh tế có thể dùng mức tăng trưởng tuyệt đối, tốc độ tăng trưởng kinh tế hoặc tốc độ tăng trưởng bình quân hàng năm trong một giai đoạn.

GNP là tổng giá trị của các sản phẩm và dịch vụ cuối cùng được tạo ra trong năm, không bao gồm các sản phẩm trung gian (là các sản phẩm được dùng để sản xuất ra sản phẩm khác). Các sản phẩm cuối cùng được bao gồm trong GNP phải là sản phẩm được sản xuất bởi người dân của đất nước đó, bao gồm cả những người đang sống ở nước ngoài.

GDP là chỉ tiêu phổ biến để đo lường tăng trưởng kinh tế. GDP đo lường tổng giá trị thị trường của các sản phẩm và dịch vụ cuối cùng được sản xuất trong một quốc gia trong một khoảng thời gian nhất định. Điểm lưu ý ở đây là các sản phẩm này phải được sản xuất trong phạm vi địa lý của quốc gia được xét đến, bao gồm các sản phẩm và dịch vụ được tạo ra bởi cư dân nước ngoài đang sinh sống trong nước, và không bao gồm các sản phẩm, dịch vụ tạo ra bởi người dân đang sống ở nước ngoài. Thu nhập bình quân đầu người của một nước được tính toán bằng cách lấy GNP hoặc GDP chia cho dân số.

Chỉ số GDP thường được sử dụng rộng rãi để đo lường thu nhập quốc gia, lý do là vì việc quản lý các hoạt động kinh tế trong nước thường dễ dàng hơn so với hoạt động kinh tế người dân đang định cư ở nước ngoài. GDP đo lường đồng thời hai chỉ tiêu: tổng thu nhập của tất cả mọi người trong nền kinh tế, và tổng chi tiêu cho sản lượng hàng hóa và dịch vụ của nền kinh tế. Chi tiêu trong nền kinh tế có nhiều 
hình thức. Để hiểu được nền kinh tế đang sử dụng các nguồn lực khan hiếm như thế nào, các nhà kinh tế chia GDP thành bốn thành phần sau đây:

$$
\mathrm{Y}=\mathrm{C}+\mathrm{I}+\mathrm{G}+\mathrm{NX}
$$

Với GDP được ký hiệu là $\mathrm{Y} ; \mathrm{C}$ là tiêu dùng của các hộ gia đình; I là đầu tư (là tổng các khoản mua sắm thiết bị sản xuất, hàng tồn kho và các công trình xây dựng); $\mathrm{G}$ là chi tiêu của chính phủ; $\mathrm{NX}$ là xuất khẩu ròng (bằng xuất khẩu trừ đi nhập khẩu, tức là chi tiêu của người nước ngoài cho hàng hóa được sản xuất trong nước trừ đi chi tiêu của cư dân trong nước cho hàng hóa nước ngoài).

Khi nghiên cứu những sự thay đổi của nền kinh tế theo thời gian, cần đo lường GDP nhưng không bị ảnh hưởng bởi những sự thay đổi về giá cả của các hàng hóa và dịch vụ. Vì vậy, các nhà kinh tế dùng chỉ tiêu GDP thực. GDP danh nghĩa phản ánh cả số lượng hàng hóa và dịch vụ mà nền kinh tế đang sản xuất và giá cả của những hàng hóa dịch vụ đó. Trái lại, bằng cách giữ giá cả cố định tại mức giá của năm cơ sở, GDP thực chỉ phản ánh số lượng được sản xuất. Từ hai số liệu thống kê trên về GDP, có thể tính ra số liệu thứ ba, gọi là chỉ số giảm phát GDP (GDP deflator), phản ánh giá cả của hàng hóa và dịch vụ, được tính toán bằng tỷ số của GDP danh nghĩa so với GDP thực rồi nhân với 100.

\subsection{Phát triển tài chính}

\subsubsection{Hệ thống tài chính}

Theo Mankiw (2011), hệ thống tài chính được định nghĩa là một nhóm các định chế trong nền kinh tế giúp kết nối tiết kiệm của người này với đầu tư của người khác, mà tiết kiệm và đầu tư chính là những thành tố quan trọng cho tăng trưởng kinh tế dài hạn. Khi một quốc gia có tỷ lệ tiết kiệm cao trên GDP, nhiều nguồn lực được sẵn sàng cho việc đầu tư vốn, làm nâng cao năng suất và mức sống của quốc gia đó. Các định chế tài chính có thể phân làm hai loại: các thị trường tài chính và các trung gian tài chính. 
Thị trường tài chính là các định chế mà thông qua đó một người tiết kiệm có thể cung cấp vốn trực tiếp đến người khác muốn vay. Các thị trường tài chính quan trọng nhất của nền kinh tế là thị trường trái phiếu và thị trường cổ phiếu.

Các trung gian tài chính là các định chế mà thông qua đó một người tiết kiệm có thể gián tiếp cung cấp vốn cho người đi vay. Vai trò của các định chế này là đứng giữa người tiết kiệm và người đi vay. Hai trong số những trung gian tài chính quan trọng nhất đó là ngân hàng và các quỹ đầu tư.

Nguyễn Trọng Hoài (2006) làm rõ hơn khái niệm về hệ thống tài chính. Theo đó, hệ thống tài chính được cấu thành từ các bộ phận gồm: tổ chức tài chính, cơ sở hạ tầng tài chính, tài sản tài chính, và thị trường tài chính. Theo cách hiểu này thì hệ thống tài chính là một tập hợp rộng lớn các mối quan hệ cung cầu về vốn diễn ra dưới hình thức vay mượn, mua bán vốn hoặc tiền tệ hoặc các chứng từ có giá, nhằm dịch chuyển vốn từ nơi cung cấp đến nơi có nhu cầu về vốn. Vốn có thể được chuyển trực tiếp bằng việc sử dụng các công cụ tài chính và thông qua các thị trường tài chính, hoặc gián tiếp thông qua các tổ chức tài chính trung gian như các ngân hàng, công ty bảo hiểm, quỹ đầu tư, công ty tài chính.

Các công cụ tài chính là quyền sở hữu một khoản thu nhập hay tài sản nào đó trong tương lai. Công cụ tài chính hay tài sản tài chính (financial instruments or financial assets) được mua bán, trao đổi trên thị trường tài chính với nhiều loại và hình thức đa dạng, bao gồm các loại cơ bản là chứng khoán vốn, chứng khoán nợ, chứng khoán phái sinh. Một số thị trường tài chính có thể chỉ mua bán các công cụ ngắn hạn và được gọi là thị trường tiền tệ. Mua bán phổ biến nhất trên thị trường tiền tệ là tín phiếu kho bạc, chứng chỉ tiền gửi có thể giao dịch và giấy nợ thương mại. Tất cả những công cụ này đều có kỳ hạn dưới một năm. Thị trường vốn là nơi mua bán các công cụ tài chính dài hạn như cổ phiếu, trái phiếu công ty và trái phiếu chính phủ.

Ngoài ra, hệ thống tài chính còn bao gồm cơ sở hạ tầng tài chính (financial infrastructure) là các tổ chức và yếu tố bổ trợ giúp cho quá trình vận hành của thị 
trường tài chính, như là khung luật pháp và các quy định đối với hoạt động của khu vực tài chính, hệ thống thanh toán, cơ quan thông tin tín dụng, cơ quan đăng ký thế chấp.

Trong thế giới hiện đại ngày này, hệ thống tài chính không phân biệt ranh giới địa lý hay chính trị mà được toàn cầu hóa trong việc cho vay, phát hành chứng khoán và cung cấp dịch vụ về tiền tiết kiệm cho người dân.

Như vậy, thông qua những khái niệm nói trên về hệ thống tài chính, có thể thấy hệ thống tài chính và sự phát triển của nó - gọi là sự phát triển tài chính - là những nhân tố quan trọng, đóng góp cho sự phát triển của nền kinh tế. Đóng góp tích cực mà hệ thống tài chính có thể thực hiện đối với quá trình phát triển kinh tế phụ thuộc vào việc thiết kế và vận hành hệ thống này chứ hệ thống tài chính tự bản thân nó không thể tạo ra tăng trưởng và phát triển kinh tế (Hermes và Lensink, 2000).

\subsubsection{Sự phát triển tài chính}

Levine (2005) định nghĩa rằng sự phát triển tài chính là việc cải thiện các chức năng được cung cấp bởi hệ thống tài chính bao gồm: tích lũy tiết kiệm, phân phối nguồn vốn đến các cơ hội đầu tư sinh lợi, giám sát và quản trị rủi ro các khoản đầu tư này, đa dạng hóa rủi ro, tạo điều kiện thuận lợi cho trao đổi hàng hóa và cung cấp dịch vụ. Mỗi chức năng nói trên của hệ thống tài chính có thể ảnh hưởng đến tiết kiệm và các quyết định đầu tư cũng như ảnh hưởng đến mức độ hiệu quả của các nguồn vốn được phân bổ. Theo Bernanke, Gertler, và Gilchrist (1999), ở một mức độ nào đó, sự phát triển tài chính có thể làm giảm bất cân xứng thông tin, giảm các hạn chế tài chính, thúc đẩy chia sẻ rủi ro. Sự phát triển tài chính cũng giúp cho hệ thống tài chính có khả năng hấp thu các cú sốc trong nền kinh tế, giảm bớt sự khuếch đại tác hại của các cú sốc bất lợi xảy ra trong nền kinh tế, hạ thấp biến động kinh tế vĩ mô và bất bình đẳng trong xã hội.

Theo Dorruci và cộng sự (2009), sự phát triển tài chính là khả năng của một quốc gia chuyển từ kênh tiết kiệm sang kênh đầu tư một cách hiệu quả bao gồm: 
(1) chất lượng của khung thể chế và các quy định

(2) quy mô của thị trường tài chính, sự đa dạng của các công cụ tài chính, mức độ dễ dàng trong việc tiếp cận các nhà đầu tư cá nhân

(3) thị trường tài chính hoạt động tốt thể hiện qua tính hiệu quả và tính thanh khoản trên thị trường.

Ngoài cách định nghĩa như trên, Hartmann và cộng sự (2007) đã nêu rằng: phát triển tài chính là quá trình đổi mới tài chính cũng như cải thiện thể chế và tổ chức trong hệ thống tài chính, làm giảm bất cân xứng thông tin, tăng sự hoàn thiện của thị trường, tăng khả năng cho các tổ chức tham gia vào các giao dịch tài chính bằng hợp đồng, giảm chi phí giao dịch, tăng sự cạnh tranh. Do đó, phạm vi của phát triển tài chính bao gồm việc cải tiến, đổi mới sản phẩm tài chính, nâng cao năng lực của các chủ thể và tổ chức trong hệ thống tài chính. Từ những định nghĩa ở trên, có thể hiểu phát triển tài chính là một quá trình cải thiện về số lượng, chất lượng và hiệu quả của dịch vụ, trung gian tài chính. Quá trình này liên quan đến sự hoạt động và tương tác của nhiều tổ chức, cá nhân khác nhau trên thị trường tài chính.

Phát triển tài chính còn được hiểu là các chính sách, các yếu tố và tổ chức đưa đến các trung gian tài chính hiệu quả và thị trường tài chính hiệu quả. Gần đây hơn và rõ ràng hơn, Noureen (2011) trong tác phẩm "Measurement of Financial Development: A Fresh Approach" đã nêu rằng phát triển tài chính được hiểu cả theo chiều rộng và theo chiều sâu. Theo chiều rộng, phát triển tài chính đề cập đến sự phát triển chủ yếu dựa vào yếu tố vốn đầu tư và lao động, gia tăng lượng vốn đầu tư phù hợp với sự gia tăng của lao động. Bên cạnh đó, phát triển tài chính còn được đề cập đến theo chiều sâu, đó là sự gia tăng tỷ lệ giá trị các tài sản tài chính so với GDP.

Như vậy, từ những định nghĩa ở trên, chúng ta có thể hiểu phát triển tài chính là một quá trình cải thiện về số lượng, chất lượng và hiệu quả của dịch vụ, trung gian tài chính. Nhiều nhà kinh tế học trên thế giới trong những công trình nghiên cứu của mình đã đề xuất những đại diện khác nhau để đo lường sự phát triển tài chính. 


\subsection{3. Đo lường sự phát triển tài chính}

Levine là học giả đã có nhiều công trình nghiên cứu nổi bật về mối quan hệ giữa phát triển tài chính và tăng trưởng kinh tế đã chỉ ra một vấn đề gây khó khăn lớn và ảnh hưởng đến toàn bộ kết quả trong các nghiên cứu về sự phát triển tài chính đó là việc đo lường biến số đại diện cho sự phát triển tài chính (Levine, 2005). Theo lý thuyết, hệ thống tài chính tác động đến sự tăng trưởng kinh tế thông qua giảm bớt các chi phí giao dịch và chi phí tìm kiếm thông tin, nhờ đó cải thiện và làm gia tăng sự năng động của các nguồn lực tài chính, tăng hiệu quả của các giao dịch liên quan đến nguồn vốn. Trong khi đó, các nghiên cứu thực nghiệm về chủ đề này lại thường không đo lường trực tiếp các chức năng này của hệ thống tài chính. Đa số các nghiên cứu thực nghiệm về chủ đề phát triển tài chính đã xuất hiện từ những năm thập niên 1970, thường sử dụng ba chỉ số phổ biến sau đây để đo lường mức độ phát triển tài chính:

\subsubsection{Tỷ số tín dụng cho khu vục tư nhân trên GDP}

Đây là chỉ số được dùng phổ biến trong các nghiên cứu về mối liên hệ giữa phát triển tài chính và tăng trưởng kinh tế. Tỷ số tín dụng cho khu vực tư nhân (private credit to GDP) phản ánh các nguồn lực vốn tài chính được cung cấp cho khu vực tư nhân bởi các định chế tài chính thông qua các khoản vay, các giao dịch chứng khoán, tín dụng thương mại, các cam kết chi trả và khoản phải thu khác. Định chế tài chính bao gồm các ngân hàng, tổ chức tài chính, các công ty tài chính, các tổ chức cho vay tiền, công ty bảo hiểm, quỹ hưu trí, quỹ tương hỗ, quỹ đầu tư, và các công ty ngoại hối nước ngoài.

Đánh giá về cách đo lường tỷ số tín dụng cho khu vực tư nhân trên GDP, Fry (1997), Ang và McKibbin (2007) có chung ý kiến rằng chỉ số này đại diện tốt cho sự phát triển tài chính. Tầm quan trọng của cách đo này chính là khả năng cho phép tính toán lượng tín dụng cung cấp cho lĩnh vực tư nhân, cho phép việc sử dụng các quỹ và phân bổ đầu tư để hoạt động hiệu quả và năng suất hơn. Thước đo này không bao gồm tín dụng từ các ngân hàng trung ương và do đó đo lường một cách chính xác hơn khoản tiết kiệm mà các trung gian tài chính chuyển đến khu vực tư nhân. Tuy nhiên, 
Cihak và cộng sự (2012) lại đánh giá rằng chỉ số này tốt, dễ thu thập dữ liệu và tín dụng là một loại hình dịch vụ tài chính quan trọng, nhưng nếu chỉ nhìn vào tín dụng tư nhân thì không cung cấp đủ nền tảng hiểu biết về phát triển tài chính. Chỉ số này phản ánh quy mô của các khoản cho vay của ngân hàng theo giá trị sổ sách so sánh với sản lượng của nền kinh tế nhưng nó lại chưa thể hiện được chất lượng của các dịch vụ tài chính, tính hiệu quả và tính ổn định của khu vực tài chính.

\subsubsection{Tỷ số tín dụng nội địa trên GDP}

Tín dụng nội địa hay còn gọi là Tín dụng trong nước (Domestic credit) bao gồm tín dụng cấp cho khu vực tư nhân và cả tín dụng cung ứng cho khu vực công, gồm chính quyền trung ương, chính quyền địa phương, doanh nghiệp nhà nước. Còn theo định nghĩa bởi World Bank, tín dụng nội địa do khu vực tài chính cung cấp bao gồm tất cả tín dụng cung ứng cho nhiều ngành nghề và khu vực khác nhau trong nền kinh tế - được tính trên số liệu gộp, riêng tín dụng cung ứng cho chính quyền trung ương thì tính trên giá trị ròng. Khu vực tài chính mà định nghĩa này đề cập bao gồm các định chế tài chính, các ngân hàng nhận tiền gửi trong nền kinh tế, các công ty tài chính, công ty cho thuê tài chính, các tổ chức cho vay, các công ty bảo hiểm, quỹ hưu trí, quỹ ngoại hối, ... Có thể thấy, chỉ tiêu này ghi nhận các chủ thể tham gia cung ứng vốn trong thị trường tài chính khá đầy đủ cũng như thể hiện nguồn vốn được dịch chuyển đến cả khu vực tư nhân lẫn khu vực công. Nhờ vậy chỉ tiêu này có thể phản ánh tốt mức độ phát triển của thị trường tài chính.

\subsubsection{Tỷ số cung tiền trên GDP}

Một chỉ số đo lường khác cũng khá phổ biến trong các nghiên cứu về chỉ đề này đó là $T y ̉$ số cung tiền M2 (hoặc M3) trên GDP danh nghĩa. Đây là tỷ số được khá nhiều công trình nghiên cứu sử dụng để nắm bắt quy mô tổng thể và độ sâu phát triển của khu vực tài chính.

Cung tiền M1 (Narrow money) bao gồm tiền mặt và tiền gửi không kỳ hạn. Cung tiền $\mathrm{M} 2=\mathrm{M} 1+$ tiền gửi tiết kiệm, tiền gửi ngắn hạn, hợp đồng có thể mua bán lại qua đêm. Cung tiền M3 = M2 + tiền gửi dài hạn, hợp đồng có thể mua bán lại. 
(Việc định nghĩa $\mathrm{M} 1, \mathrm{M} 2, \mathrm{M} 3$ còn tùy thuộc chuẩn mực thống kê của quốc gia và tổ chức thống kê, ví dụ: định nghĩa của Cục Dự trữ liên bang Mỹ (FED) có khác đôi chút so với định nghĩa của Ngân hàng Trung ương châu Âu hay IMF, Worldbank).

Tuy nhiên, một số nhà kinh tế học như Khan và Senhadji (2003) lập luận rằng tỷ số M2/GDP có thể là một đại diện không đầy đủ cho sự phát triển tài chính trong trường hợp các quốc gia có hệ thống tài chính kém phát triển vì hai lý do. Một là mức độ tiền tệ hóa cao có thể liên kết với với sự kém phát triển của hệ thống tài chính. Hai là $\mathrm{M} 2$ chủ yếu nắm bắt khả năng của hệ thống tài chính trong việc cung cấp các dịch vụ giao dịch hơn là khả năng liên kết giữa tình trạng thặng dư và thâm hụt trong nền kinh tế. Vì vậy, để đại diện tốt hơn cho vấn đề luân chuyển vốn trong nền kinh tế, các bài nghiên cứu thường chọn sử dụng tỷ số $\mathrm{M} 3 / \mathrm{GDP}$ để đo lường sự phát triển tài chính như Beck, Levine, và Loayza (2000); Deidda và Fattouh (2002), Favara (2003). Tỷ số M3/GDP còn có cách gọi khác là tỷ số Nợ thanh khoản trên GDP (Liquid Liabilities to GDP).

Mặc dù tỷ lệ M3/GDP nắm bắt được lượng nợ thanh khoản của hệ thống tài chính, bao gồm các khoản nợ của các ngân hàng thương mại, ngân hàng trung ương, và các trung gian tài chính khác, phản ánh được độ sâu tài chính nhưng theo Fry (1997), Ang và McKibbin (2007), đó không hẳn là một đại diện tốt cho sự phát triển tài chính. Nguyên nhân là chỉ số này chỉ phản ánh phạm vi của dịch vụ giao dịch được cung cấp bởi hệ thống tài chính chứ không phải khả năng của hệ thống tài chính cho kênh chu chuyển vốn từ người gửi tiền đến nhà đầu tư.

Trên đây là các cách thức đo lường được sử dụng rộng rãi trong các nghiên cứu trước, như Arcand và cộng sự (2012) sử dụng tỷ số tín dụng tư nhân trên GDP để kiểm định với mô hình hồi quy ngưỡng và xác định mức giới hạn mà vượt qua nó thì phát triển tài chính không còn tác động tích cực lên tăng trưởng kinh tế nữa. Trên khía cạnh phân tích về biến động kinh tế vĩ mô, Dabla-Norris và Srivisal (2013) tìm thấy rằng khi đo lường phát triển tài chính bằng tỷ số tín dụng tư nhân được cung ứng bởi ngân hàng và các định chế tài chính khác so với GDP thì nó có tác động có ý 
nghĩa thống kê làm giảm bớt sự biến động trong sản lượng nền kinh tế, tiêu dùng, và trong tăng trưởng của đầu tư nhưng vai trò hữu ích này chỉ tồn tạo cho đến một mức ngưỡng giới hạn của phát triển tài chính mà thôi. Law và Singh (2014) đã công bố kết quả nghiên cứu của họ trên tạp chí chuyên ngành uy tín, sử dụng đồng thời các thước đo Tỷ số tín dụng nội địa trên GDP, Tỷ số tín dụng tư nhân trên GDP, và chỉ số Nợ thanh khoản (Liquid Liabilities) nhằm phản ánh chính xác hơn về tình hình tại các nước đang phát triển. Theo hai tác giả này, đa số các quốc gia đang phát triển thì dữ liệu về thị trường chứng khoán chưa được ghi nhận đầy đủ, hoặc chưa có thị trường chứng khoán. Đối với những nền kinh tế này, để phục vụ cho phân tích trong dài hạn thì nguồn dữ liệu khả thi nhất chỉ là các chỉ số phản ánh sự phát triển của ngành ngân hàng. Tuy nhiên các tác giả này cũng trình bày lý do thuyết phục đó là các tài liệu nghiên cứu trước của các học giả có uy tín như Levine và Zervos (1998), Levine (2002) đã nêu rằng hầu hết các nền kinh tế tăng trưởng cùng với sự phát triển của hệ thống ngân hàng bởi vì nhờ có sự phát triển của hệ thống ngân hàng mà nền kinh tế mở rộng được sự lựa chọn ngành nghề, gia tăng được sản lượng do dòng vốn dịch chuyển từ người tiết kiệm sang các nhà đầu tư sản xuất.

\subsubsection{Các chỉ tiêu đo luờng về thị truò̀ng tài chính so với GDP}

Ngoài ba cách đo lường phổ biến nêu trên, trong các nghiên cứu hiện đại liên quan đến phát triển tài chính còn sử dụng chỉ tiêu liên quan đến mức độ phát triển của thị trường chứng khoán, là một bộ phận của thị trường tài chính, như Rajan và Zingales (1998) sử dụng cả hai cách đo lường Tỷ số tín dụng cho khu vực tư nhân và Quy mô vốn hóa thị trường cổ phiếu trên GDP trong nghiên cứu của họ và chứng minh rằng càng phát triển tài chính càng thúc đẩy tăng trưởng kinh tế.

Quy mô vốn hóa thị trường chứng khoán trên GDP là tỷ số phản ánh tổng giá trị vốn hóa thị trường chứng khoán - là một bộ phận cấu thành của hệ thống tài chính trong nền kinh tế - so với sản lượng quốc gia, qua đó thấy được quy mô và mức độ phát triển của thị trường này. 
Quy mô giao dịch của TTCK trên GDP là tỷ lệ \% tổng giá trị bằng tiển của tất cả các giao dịch mua bán chứng khoán trên thị trường niêm yết so với GDP.

Mặc dù hữu ích nhưng các chỉ số trên khó được thu thập đầy đủ do một số quốc gia chưa phát triển thị trường chứng khoán hoặc chưa cập nhật thông tin về thị trường này, cũng là một trở ngại cho các nghiên cứu thực nghiệm. Cũng có thể thấy, không có hoặc không cập nhật dữ liệu về TTCK phản ánh mức độ phát triển tài chính kém tại quốc gia đó.

Ngoài ra, Cihak và cộng sự (2012) còn đề xuất nhiều chỉ số khác nhằm phản ánh các khía cạnh của thị trường chứng khoán, trong đó có chỉ tiêu quan trọng thể hiện tính hiệu quả của thị trường này là Tỷ số sinh lọ̣i của thị trường chứng khoán. Theo định nghĩa của Ngân hàng Thế giới, chỉ tiêu này phản ánh Tổng giá trị cổ phiếu được giao dịch trong kỳ chia cho giá trị vốn hóa thị trường trung bình trong kỳ.

\subsubsection{Các phương pháp đo lường khác}

Ngoài các phương pháp đo lường nói trên, một số nhà nghiên cứu về chủ đề vai trò của phát triển tài chính lên tăng trưởng kinh tế còn dùng nhiều biến thể khác dựa trên các chỉ tiêu đo lường cơ bản này như Tee và cộng sự (2014) phản ánh quy mô tổng thể của phát triển tài chính bằng cách tính tổng của tỷ số Tín dụng tư nhân trên GDP và tỷ số Quy mô vốn hóa thị trường chứng khoán trên GDP; đo lường khả năng hoạt động của thị trường tài chính bằng tích của hai chỉ tiêu trên; phản ánh cấu trúc của thị trường tài chính bằng cách lấy tỷ số Tín dụng tư nhân trên GDP chia cho tỷ số Quy mô vốn hóa thị trường chứng khoán trên GDP, hay lấy khối lượng giao dịch trên thị trường cổ phiếu chia cho độ lệch chuẩn của tỷ suất sinh lợi của thị trường cổ phiếu. Các cách làm nói trên không có nền tảng lý thuyết hỗ trợ nên không được những nhà nghiên cứu đi sau ủng hộ.

Một số nghiên cứu khác lại dùng tỷ số tài sản của ngân hàng thuơng mai chia cho tổng tài sản của ngân hàng thương mại và ngân hàng trung uơng (Samargandi và cộng sự, 2013; Ang và McKibbin, 2007; Campos và Kinoshita, 2008; Rioja và Valev, 2004a, 2004b). Biến số này đo lường tầm quan trọng tương đối của một loại 
hình tổ chức tài chính cụ thể là ngân hàng thương mại trong hệ thống tài chính. Ang và McKibbin (2007) lập luận rằng lợi thế của thước đo này là cho thấy khả năng các ngân hàng thương mại sử dụng các quỹ hiệu quả hơn so với ngân hàng trung ương trong việc chu chuyển vốn tiết kiệm đến các cơ hội đầu tư sinh lợi. Tuy nhiên số lượng nghiên cứu sử dụng phương pháp đo lường này khá ít ỏi và thời gian gần đây các bài nghiên cứu không sử dụng phương pháp này vì nó chỉ phản ánh cục bộ một khía cạnh về tài sản của ngân hàng thương mại, chưa phản ánh hết các chủ thể trong thị trường tạo nên sự phát triển tài chính.

Bên cạnh đó, Boy và Jalad (2012) còn trình bày một nghiên cứu về phương pháp đo lường khác đối với sự phát triển tài chính, sử dụng nguồn dữ liệu vi mô. Hai tác giả này lập luận và phát triển ý tưởng dựa trên lý thuyết của Myers (1984), Myers và Majluf (1984), Shyam-Sunder và Myers (1999), Gurley và Shaw (1995) để xây dựng chí số đo lường MUD (Marginal Utilization of Debt) phản ánh các điều kiện trên cả thị trường nợ lẫn thị trường vốn cổ phần. Hai ông cho rằng với phương pháp đề xuất này thì các chỉ báo rời rạc được kết nối thành các biến liên tục, tập trung vào vai trò của chi phí giao dịch và chi phí tìm kiếm thông tin trên các thị trường tài chính. Tuy nhiên phương pháp này có nhược điểm là không tiếp cận được dữ liệu đối với các nước đang phát triển, nơi mà hệ thống công bố và lưu trữ thông tin chưa đồng bộ và nhất quán, vì thế cách tiếp cận này không được sử dụng rộng rãi.

Thời gian gần đây, xuất hiện một phương pháp đo lường mới đang được thử nghiệm của tổ chức IMF đề xuất từ năm 2016. Các chuyên gia của IMF cho rằng phát triển tài chính là một quá trình đa chiều. Hai chỉ tiêu đo lường theo truyền thống nói trên không phản ánh được bản chất đa chiều phức tạp của phát triển tài chính. Họ lập luận rằng: theo thời gian, khu vực tài chính đã phát triển trên toàn cầu và các hệ thống tài chính hiện đại của các nước đã trở nên đa diện. Điều này có nghĩa là: trong lúc các ngân hàng vẫn giữ vai trò lớn nhất và quan trọng nhất trong hệ thống tài chính thì các ngân hàng đầu tư, công ty bảo hiểm, quỹ hỗ tương, quỹ hưu trí, quỹ đầu tư mạo hiểm, và các loại hình định chế tài chính khác hiện nay cũng đang giữ vai trò quan trọng trong hệ thống tài chính. Tương tự, các thị trường tài chính đã và đang phát triển theo 
nhiều cách thức khác nhau, cho phép các cá nhân và doanh nghiệp đa dạng hóa các loại hình tiết kiệm của họ, các công ty giờ đây ngoài cách truyền thống là đi vay từ ngân hàng có thể kêu gọi vốn thông qua phát hành cổ phiếu, trái phiếu, và các chứng từ có giá trên thị trường tiền tệ. Sự phát triển mạnh mẽ của các định chế tài chính và thị trường tài chính đã tạo điều kiện để cung cấp thêm nhiều dịch vụ tài chính cho nền kinh tế (Svirydzenka, 2016). Một đặc điểm quan trọng của hệ thống tài chính đó là khả năng tiếp cận và tính hiệu quả của nó. Cihak và cộng sự (2012); Aizenman, Jinjarak, và Park (2015), Svirydzenka (2016) nhất trí với quan điểm rằng nếu không thể tiếp cận đến phần đông dân cư và các doanh nghiệp thì mức độ hữu ích của các hệ thống tài chính lớn cũng bị giới hạn. Thậm chí là nếu các hệ thống tài chính có quy mô lớn và mức độ tiếp cận rộng lớn nhưng hoạt động không hiệu quả, gây lãng phí nguồn lực thì chúng cũng sẽ không đóng góp gì được cho sự phát triển của nền kinh tế. Vì vậy, theo quan điểm của các chuyên gia IMF, họ cho rằng cách tiếp cận rời rạc như các phương pháp đo lường truyền thống là không phù hợp, cần phải có một chỉ số tổng hợp phản ánh được đa chiều của sự phát triển tài chính. Vì vậy, năm 2016, các chuyên gia này đã xây dựng bộ chỉ số tổng hợp gồm 9 chỉ tiêu nhằm phản ánh mức độ phát triển của các định chế tài chính và của thị trường tài chính trên phương diện độ sâu, khả năng tiếp cận, và tính hiệu quả. Cách đo lường này kế thừa từ ma trận đa chiều các đặc tính của hệ thống tài chính mà Cihak và cộng sự (2012) đã phát triển. Nguồn số liệu để tổng hợp nên bộ chỉ số này từ các nguồn quốc tế bao gồm World Bank FinStats, Global Financial Development Database (GFDD) kết hợp thêm với số liệu từ Bank of International Settlements (BIS), Dealogic corporate debt database, và IMF Financial Access Survey. Từ 105 chỉ số riêng lẻ trong GFDD và 46 chỉ số trong FinStats, các chuyên gia này đã xây dựng các chỉ số phụ FID, FIA, FIE, FMD, FMA, FME, FI, FM rồi mới tổng hợp thành chỉ số FD tổng thể, cho phép đánh giá toàn diện về hệ thống tài chính. Chỉ số FD đánh giá về sự phát triển của hệ thống tài chính trên ba khía cạnh:

$\checkmark$ Độ sâu (Depth - tức là quy mô và tính thanh khoản) 
$\checkmark$ Khả năng tiếp cận (Access - tức là khả năng mà các cá nhân và doanh nghiệp có thể tiếp cận được các dịch vụ tài chính)

$\checkmark$ Tính hiệu quả (Efficiency - tức là khả năng mà các định chế có thể cung cấp các dịch vụ tài chính với chi phí thấp mà vẫn đảm bảo doanh thu bền vững, và mức độ hoạt động của thị trường vốn)

Các chỉ tiêu thành phần trong bộ chỉ số được tổng hợp thành một chỉ số tổng thể để phản ánh phát triển tài chính của mỗi quốc gia. Trong cách đo lường mới này, các định chế tài chính bao gồm các ngân hàng, công ty bảo hiểm, quỹ hỗ tương, và quỹ hưu trí. Thị trường tài chính bao gồm thị trường cổ phiếu và trái phiếu.

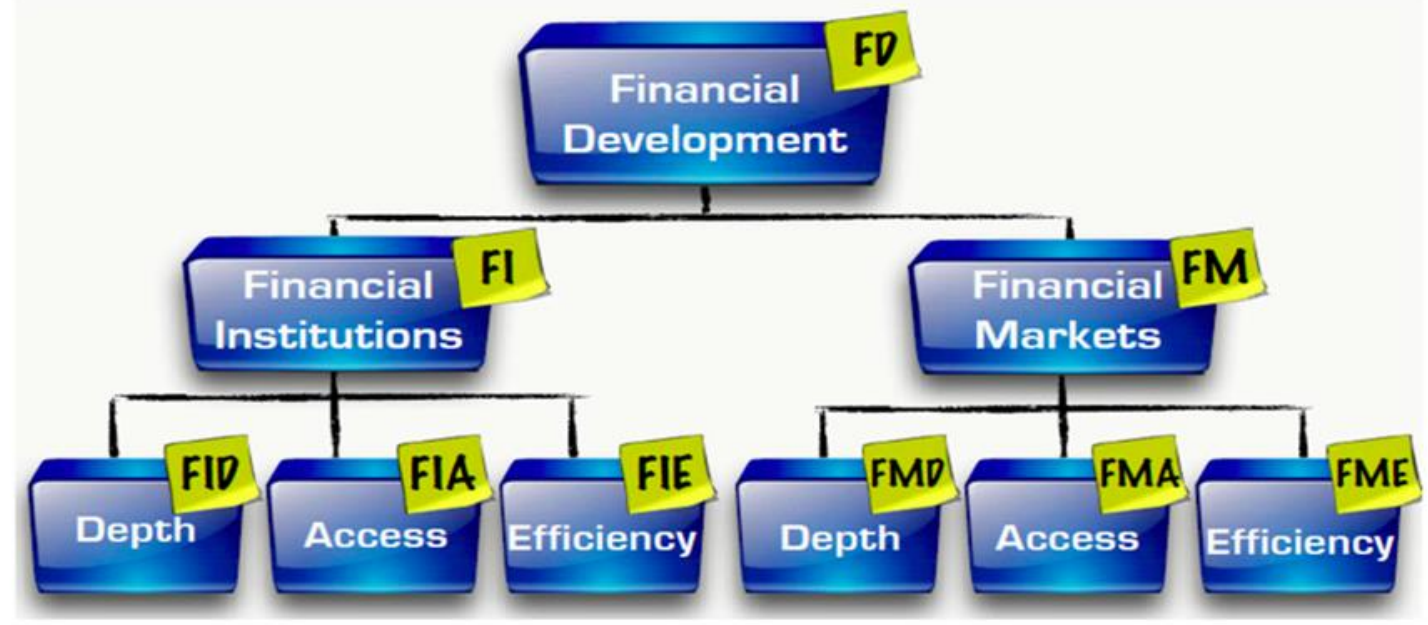

Hình 2.1 Bộ chỉ số FD đo lường phát triển tài chính của IMF

Nguồn: IMF, dựa trên nghiên cứu của Cihak và cộng sụ (2012)

Theo các tác giả xây dựng bộ chỉ số này, đối với các quốc gia thu nhập thấp, hoặc đang phát triển, dữ liệu trước năm 2004 thường không được ghi nhận, hoặc thị trường chứng khoán quốc gia của họ chưa phát triển nên không có số liệu. Trường hợp bị thiếu số liệu trong một năm thì giá trị được ghi nhận bằng với giá trị của năm quan sát gần nhất với nó (ví dụ thiếu năm 2013 thì lấy giá trị bằng giá trị năm 2012) hoặc dùng kỹ thuật nối số liệu (splicing) theo xu hướng tốc độ tăng trưởng trung bình của các chuỗi số liệu khác cùng loại có thể tiếp cận được. Trường hợp dữ liệu về quốc gia đó hoàn toàn không có (ví dụ do thị trường chứng khoán chưa phát triển) thì mức 
điểm đánh giá cho quốc gia đó bằng 0 , hàm ý rằng thị trường không tồn tại, hoặc mức độ tiếp cận, mức độ hiệu quả của thị trường rất kém.

Mặc dù thể hiện một cách tiếp cận mới để đo lường mức độ phát triển tài chính nhưng bộ chỉ số này vẫn chưa hoàn chỉnh, cụ thể là: theo Cihak và cộng sự (2012) thì hệ thống tài chính có đến bốn phương diện nên được phản ánh, ngoài độ sâu, khả năng tiếp cận, tính hiệu quả thì còn cần đánh giá về tính ổn định (Stability) nhưng các tác giả trên chưa tiếp cận được dữ liệu này của các nước.

Bộ chỉ số này là vẫn đang là một dự án đang trong giai đoạn thử nghiệm của IMF còn đang được đóng góp ý kiến, nhiều chỉ tiêu phụ để đo lường của một số quốc gia bị thiếu dữ liệu thì được đánh đồng với mức điểm số bằng 0 , tương đương trường hợp kém phát triển. Cách tiếp cận và đánh giá này là chưa hợp lý.

Bộ chỉ số FD này được trình bày ở đây với mục đích thấy được xu hướng mới và những nỗ lực hiện nay của giới chuyên gia nhằm đo lường mức độ phát triển tài chính, nhưng bởi vì nó vẫn đang còn cần được tiếp tục hoàn thiện theo các ý kiến góp ý của các chuyên gia, cho nên trong luận án này không sử dụng cách đo lường FD nói trên.

\subsection{Vai trò của phát triển tài chính trong các lý thuyết tăng trưởng kinh tế}

Trước thế kỷ XVIII, các nhà kinh tế học không chú ý nhiều đến tăng trưởng kinh tế vì họ cho rằng thu nhập bình quân đầu người luôn luôn ở mức đủ sống. Thậm chí trong giai đoạn này, trường phái kinh tế học trọng nông còn cho rằng tăng trưởng chỉ có được trong khu vực nông nghiệp bởi vì chỉ có khai thác đất đai mới có thể tạo ra sản phẩm thặng dư, còn ngành chế tạo không thể tạo ra tăng trưởng kinh tế. Theo thời gian, các nước ngày càng phát triển, dân số ngày càng tăng gây áp lực lên nền kinh tế, lợi tức trong khu vực nông nghiệp giảm dần và thấp hơn so với năng suất của khu vực công nghiệp. Lúc này, các nhà kinh tế học đã nhận thấy tầm quan trọng của các nghiên cứu về tăng trưởng kinh tế nên một loạt các mô hình tăng trưởng kinh tế và trường phái lý thuyết đã ra đời, được trình bày tóm tắt trong bảng 2.1 
Bảng 2.1 Tóm lược các lý thuyết về tăng trưởng kinh tế

\begin{tabular}{|c|c|c|}
\hline $\begin{array}{l}\text { Trường } \\
\text { nhái }\end{array}$ & Nội dung & Tác giả tiêu biểu \\
\hline \multirow[t]{2}{*}{ Cổ điển } & $\begin{array}{l}\text { - Quá trình tích lũy tư bản (vốn vật chất) } \\
\text { tạo ra tăng trưởng kinh tế. } \\
\text { - Tiến bộ công nghệ, các nhân tố xã hội } \\
\text { (tự do văn hóa) và thể chế cũng giữ vai } \\
\text { trò quan trọng trong quá trình phát triển } \\
\text { kinh tế của một nước. }\end{array}$ & Adam Smith (1776) \\
\hline & $\begin{array}{l}\text { - Giới hạn đối với tăng trưởng kinh tế là } \\
\text { do các nguồn tài nguyên thiên nhiên có } \\
\text { giới hạn. }\end{array}$ & David Ricardo (1817) \\
\hline $\begin{array}{l}\text { Trường phái } \\
\text { Keynes }\end{array}$ & $\begin{array}{l}\text { - Chính phủ cần chủ động trong việc } \\
\text { quản lý và duy trì tăng trưởng kinh tế. }\end{array}$ & Keynes (1936) \\
\hline $\begin{array}{l}\text { Mô hình } \\
\text { Harrod - } \\
\text { Domar }\end{array}$ & $\begin{array}{l}\text { - Trọng tâm là hàm sản xuất với hệ số cố } \\
\text { định và hàm hiệu suất không đổi theo } \\
\text { quy mô. } \\
\text { - Mọi nền kinh tế đều phải dành một tỷ } \\
\text { lệ thu nhập nhất định để bù đắp những } \\
\text { hao mòn của trữ lượng vốn đã đầu tư. } \\
\text { Nếu nền kinh tế muốn thúc đẩy tăng } \\
\text { trưởng thì tất yếu phải có đầu tư mới. } \\
\text { - Nhấn mạnh vai trò thiết yếu của tiết } \\
\text { kiệm và hiệu quả của vốn đầu tư đối } \\
\text { với tăng trưởng kinh tế. }\end{array}$ & $\begin{array}{l}\text { Harrod, R.F(1939) } \\
\text { Domar, E. (1946) }\end{array}$ \\
\hline $\begin{array}{l}\text { Mô hình } \\
\text { tăng trưởng } \\
\text { Tân cổ điển } \\
\text { (Solow - } \\
\text { Swan; tăng } \\
\text { trưởng } \\
\text { ngoại sinh) }\end{array}$ & $\begin{array}{l}\text { - Tăng trưởng kinh tế không liên quan } \\
\text { đến các nhân tố bên trong, mà sẽ hội tụ } \\
\text { về một tốc độ nhất định ở trạng thái bền } \\
\text { vững. } \\
\text { - Tiết kiệm, tăng dân số, tiến bộ công } \\
\text { nghệ (là các yếu tố ngoại sinh) ảnh } \\
\text { hưởng đến mức sản lượng và tốc độ } \\
\text { tăng trưởng kinh tế. }\end{array}$ & $\begin{array}{l}\text { Solow (1956), } \\
\text { và Swan (1956) }\end{array}$ \\
\hline
\end{tabular}




\begin{tabular}{|c|c|c|}
\hline $\begin{array}{l}\text { Mô hình } \\
\text { tăng trưởng } \\
\text { nội sinh }\end{array}$ & $\begin{array}{l}\text { - Nhân tố thúc đẩy tăng trưởng dài hạn } \\
\text { là nội sinh (được hình thành ngay trong } \\
\text { quá trình tăng trưởng) dẫn tới sự tăng } \\
\text { trưởng liên tục của các nền kinh tế. } \\
\text { - Có hai nhân tố nội sinh chủ yếu: vốn } \\
\text { vật chất; kiến thức và vốn con người } \\
\text { - Chính sách của chính phủ có thể tác } \\
\text { động tới tốc độ tăng trưởng dài hạn. }\end{array}$ & $\begin{array}{l}\text { Arrow (1962): Mô hình } \\
\text { Learning-by-doing. } \\
\text { Romer (1990): Mô hình } \\
\text { R\&D. Mankiw, Romer } \\
\text { và Weil (1992): Mô } \\
\text { hình Human Capital } \\
\text { Barro (1991): Mô hình } \\
\text { AK. Lucas (1988): Mô } \\
\text { hình Learning-or- } \\
\text { Doing }\end{array}$ \\
\hline
\end{tabular}

Nguồn: Tác giả tổng hợp

Qua bảng lược khảo trên có thể thấy dù rằng các trường phái lý thuyết về tăng trưởng kinh tế có những lập luận khác biệt nhau nhưng đều hướng đến làm rõ các nhân tố nào tác động và các giới hạn đối với tăng trưởng. Theo thời gian, các mô hình tăng trưởng kinh tế ngày càng được mở rộng hơn và phân tích lượng hóa sâu sắc hơn, thích nghi với những biến chuyển trong bối cảnh kinh tế-chính trị toàn cầu nhưng ngay từ những mô hình cổ điển của Adam Smith và David Ricardo cho đến những mô hình tăng trưởng nội sinh thời hiện đại ngày nay thì nhân tố nguồn vốn (capital) vẫn là một yếu tố luôn xuất hiện trong các phân tích của các nhà kinh tế học.

Adam Smith (1776) và David Ricardo (1817) trong các luận điểm của mình đã nhấn mạnh rằng: tích lũy vốn là động cơ, là nguồn gốc để tạo nên sự tăng trưởng kinh tế. Nhờ có nguồn vốn (capital) mà nhà tư bản có thể đầu tư cho công xưởng, nguyên vật liệu, dụng cụ lao động, trả lương công nhân, nhờ đó thúc đẩy phân công lao động và gia tăng năng suất lao động, tạo ra sự tăng trưởng kinh tế. Cũng như Adam Smith, lý thuyết tăng trưởng của David Ricardo cũng cho rằng sự tích lũy vốn tư bản ở các ngành công nghiệp hiện đại giữ vai trò quan trọng thúc đẩy tăng trưởng kinh tế. Các nhà kinh tế học cổ điển đều có điểm chung là đã thấy được tầm quan trọng của sự tích lũy vốn tư bản cao độ dựa trên tiết kiệm và đầu tư cao chính là nguồn gốc của tăng trưởng kinh tế. Mặc dù các tư tưởng này đã cách đây khá lâu, mang tính mơ hồ, sơ khai nhưng đã tạo ra các tiền đề về nhận thức. Vì vậy ngày nay, bên cạnh 
các yếu tố cơ bản khác, vốn vật chất (capital) là yếu tố không thể thiếu trong các mô hình tăng trưởng kinh tế hiện đại.

Tiếp nối trong lịch sử của các học thuyết, mô hình tăng trưởng của Harrod Domar, dựa vào tư tưởng của Keynes (1936) về vai trò của vốn đầu tư trong tăng trưởng kinh tế, đã tập trung phân tích tăng trưởng trong mối quan hệ với tiết kiệm và đầu tư, nhấn mạnh vào vai trò của tích lũy vốn trong quá trình tăng trưởng. Hàm sản xuất được xây dựng trong mô hình Harrod - Domar ở một dạng thức rất rõ ràng: sản lượng đầu ra $(\mathrm{Y})$ là một hàm tuyến tính với vốn $(\mathrm{K})$ :

$$
Y=\frac{K}{v}
$$

Từ đó suy ra rằng, sự thay đổi trong sản lượng đầu ra $(\mathrm{Y})$, hay là mức tăng trưởng kinh tế, là do sự thay đổi trong vốn:

$$
\Delta \mathrm{Y}=\frac{\Delta \mathrm{K}}{\mathrm{V}}
$$

Mô hình Harrod-Domar nói lên rằng tốc độ tăng trưởng của GDP được xác định đồng thời bởi tỷ lệ tiết kiệm và hệ số phản ánh mức độ hiệu quả của đầu tư (ICOR). Theo đó, để tăng trưởng thì các nền kinh tế phải tiết kiệm và đầu tư một phần thu nhập của mình. Tuy nhiên, hai nhà kinh tế học này cũng chỉ dừng ở việc nhấn mạnh vai trò thiết yếu của tiết kiệm và hiệu quả của vốn đầu tư đối với tăng trưởng kinh tế. Trong bối cảnh thời kỳ đầu phát triển của kinh tế học, hai ông chưa làm rõ bằng cách nào để huy động tiết kiệm một cách hiệu quả, đồng vốn nên luân chuyển thế nào từ nơi nhàn rỗi sang đầu tư sao cho đạt hiệu suất cao. Harrod-Domar giả định trong mô hình của mình rằng tiết kiệm được chuyển sang đầu tư một cách dễ dàng. Một số tài liệu trước đây phê phán giả định này của mô hình Harrod-Domar là phi lý, cho rằng cách xem xét tăng trưởng kinh tế dài hạn này là sai lầm (Solow, 1994). Mặc dù vậy, ngày nay khi nhìn nhận ở khía cạnh phát triển xã hội thời hiện đại thì các luận điểm của Harrod và Domar vẫn có những ý nghĩa làm tiền đề cho các phân tích đi sau, đó là muốn tăng trưởng kinh tế, nhất thiết phải tiết kiệm thu nhập và tái đầu tư 
sao cho đồng vốn được sử dụng có hiệu quả, hàm ý hướng đến hệ thống tài chính trong nền kinh tế cần phải được phát triển một cách hiệu quả.

King và Levine (1993a) chỉ ra rằng tốc độ tích lũy vốn và hiệu quả sử dụng vốn được tăng cường bởi sự phát triển của các dịch vụ tài chính. Một hệ thống tài chính hoạt động tốt có thể thúc đẩy tăng trưởng kinh tế không chỉ bằng cách huy động vốn từ tiết kiệm cho đầu tư, mà quan trọng hơn là phân bổ vốn một cách hiệu quả, từ đó cải thiện năng suất của nền kinh tế.

Tiếp nối sau mô hình Harrod-Domar là sự ra đời của lý thuyết tăng trưởng của Solow và Swan (1956), hay còn gọi là mô hình tăng trưởng Tân cổ điển, dù không đi sâu phân tích về vốn nhưng đây vẫn là yếu tố giữ vai trò quan trọng trong phương trình tăng trưởng. Nếu như mô hình Harrod-Domar chỉ xét đến vai trò của vốn sản xuất thông qua tiết kiệm và đầu tư thì mô hình Solow-Swan (gọi tắt là mô hình Solow) đưa thêm nhân tố lao động và tiến bộ công nghệ vào phương trình tăng trưởng. Nền kinh tế kết hợp vốn, lao động, và kiến thức để sản xuất ra sản lượng. Ngày nay chúng ta hiểu rằng trong nền kinh tế, muốn tăng cường các tiến bộ công nghệ để thúc đẩy tăng trưởng sản lượng và phát triển xã hội đòi hỏi phải có vốn đầu tư đáng kể, lượng vốn đầu tư cũng phải gia tăng phù hợp với sự gia tăng của lao động, muốn vậy các quốc gia cần một hệ thống tài chính phát triển vững bền cả chiều rộng lẫn chiều sâu. Mức độ phát triển tài chính càng cao cho thấy khu vực tài chính càng thực hiện tốt chức năng của nó, thể hiện tính hiệu quả trong việc huy động vốn và phân bổ vốn đem lại tính hữu ích cao nhất cho đồng vốn đầu tư. Như vậy, sự phát triển của khu vực tài chính được xem là một chất xúc tác chính yếu đóng góp tích cực cho sự tăng trưởng của nền kinh tế.

Đặc biệt, đến thế kỷ XX với sự ra đời của các lý thuyết tăng trưởng kinh tế nội sinh thì vấn đề về ảnh hưởng của sự phát triển tài chính lên tăng trưởng kinh tế một lần nữa thu hút mạnh mẽ sự chú ý của các nhà nghiên cứu. Các nhà kinh tế học tiêu biểu cho trường phái này như Lucas (1988), Barro (1991), Mankiw, Romer và Weil (1992) cho rằng vốn cần được hiểu theo nghĩa rộng, bao gồm cả vốn vật chất (capital) 
và vốn con người (human capital), nhờ đó có thể tăng khả năng giải thích sự chênh lệch bình quân đầu người giữa các quốc gia dựa trên vốn. Dù mở rộng thêm quan điểm về vốn, một lần nữa, trong các mô hình tăng trưởng hiện đại này, vốn vẫn là yếu tố thiết yếu, cho thấy vai trò quan trọng của tích lũy vốn thông qua hệ thống tài chính của nền kinh tế. Levine (2005) đánh giá rằng sự phát triển tài chính tác động đến quá trình tích tụ vốn vật chất cũng như vốn con người, và tác động đến năng suất nhân tố tổng hợp (Total Factor Productivity). Đây chính là ba nhân tố cơ bản tác động đến tăng trưởng kinh tế. Chính vì vậy, xuất hiện nhiều nghiên cứu thực nghiệm tập trung vào đánh giá vai trò của phát triển tài chính đối với tăng trưởng kinh tế.

Ngày nay, không chỉ có các nhân tố đã được đề cập trong lý thuyết cổ điển như Lao động, Vốn vật chất là quan trọng trong các mô hình tăng trưởng kinh tế mà Phát triển tài chính, Vốn con người, Kỹ thuật, Công nghệ, và các nhân tố ngoại sinh khác đã trở thành tâm điểm cho các thảo luận về tăng trưởng kinh tế. Phần tiếp theo sẽ trình bày các bằng chứng thực nghiệm về ảnh hưởng của tích lũy vốn trong nền kinh tế thông qua sự phát triển của hệ thống tài chính đã tác động ra sao đến tăng trưởng kinh tế quốc gia.

\subsection{Bằng chứng thực nghiệm tác động của Phát triển tài chính đến Tăng trưởng kinh tế}

Tác động của sự phát triển tài chính lên tăng trưởng kinh tế đã thu hút mạnh mẽ sự chú ý của các nhà nghiên cứu. Mặc dù đều đồng tình rằng phát triển tài chính có vai trò quan trọng đối với tăng trưởng kinh tế nhưng nhiều học giả trong các tài liệu nghiên cứu trước lại đưa ra các kết luận thực nghiệm khác nhau liên quan đến cách thức và mức độ tác động của nhân tố này, thậm chí xuất hiện nhiều quan điểm trái chiều nhau.

Trước đây với các bằng chứng thực nghiệm ủng hộ, các nhà nghiên cứu xác định rằng hệ thống tài chính càng phát triển thì càng thúc đẩy tăng trưởng kinh tế. Đây là nhóm quan điểm nhận được nhiều sự đồng thuận của các nhà nghiên cứu từ trước cho đến thời gian gần đây. Mặc dù vậy, Lucas (1988) tuyên bố rằng các nhà 
kinh tế học đang đề cao thái quá vai trò của các nhân tố tài chính lên tăng trưởng kinh tế. Một số tác giả còn tìm thấy bằng chứng ngược lại cho thấy sự phát triển tài chính gây ra tác động tiêu cực và cản trở đối với tăng trưởng kinh tế, hoặc cho rằng không đủ bằng chứng để xác nhận tác động tích cực của nhân tố này đến tăng trưởng. Nhìn chung, những kết quả nghiên cứu thực nghiệm trước đây trên thế giới có thể được phân chia thành hai xu hướng chính như sau:

(1) Sự phát triển tài chính ảnh hưởng tuyến tính và tác động tích cực lên tăng trưởng kinh tế.

(2) Mối quan hệ giữa phát triển tài chính và tăng trưởng kinh tế là phi tuyến, vì thế trong phạm vi nào đó, sự phát triển tài chính thay đổi ảnh hưởng từ tích cực thành tiêu cực lên tăng trưởng kinh tế.

Phần tiếp theo của luận án trình bày chi tiết về các bằng chứng thực nghiệm của hai xu hướng nói trên.

\subsubsection{Tác động tích cực của Phát triển tài chính đến tăng trưởng kinh tế}

Đây là xu hướng được nhiều sự đồng thuận và chiếm ưu thế chủ đạo trong các tài liệu nghiên cứu trước đây. Những người theo quan điểm này cho rằng hệ thống tài chính kém phát triển làm hạn chế tăng trưởng kinh tế. Do vậy, chính sách của chính phủ phải hướng tới khuyến khích sự phát triển của hệ thống tài chính. Nhiều công trình nghiên cứu thực nghiệm của các học giả uy tín đã chứng thực, xác nhận rằng có một mối tương quan dương trong dài hạn giữa chỉ số thể hiện sự phát triển tài chính và tăng trưởng kinh tế như nghiên cứu của Schumeter và Opie (1934); Gurley và Shaw (1955); McKinnon (1973), Shaw (1973), và nhiều công trình sau đó cũng đồng ý với quan điểm này như nghiên cứu của King và Levine (1993a,b), Levine (1997, 2003), Rajan và Zingales (1998), Levine và cộng sự (2000), Beck và Levine (2004), Beck và cộng sự $(2000,2005)$. Các học giả này cho rằng phát triển tài chính liên quan đến việc tích lũy vốn, chính là động lực cho tăng trưởng kinh tế theo quan điểm của lý thuyết tăng trưởng Tân cổ điển và lý thuyết tăng trưởng nội sinh. 
Schumpeter và Opie (1934) giải thích rằng sự phát triển tài chính thể hiện thông qua việc gia tăng về quy mô cũng như chất lượng của các tổ chức tài chính sẽ thúc đẩy tăng trưởng kinh tế. Cụ thể, với số lượng các tổ chức tài chính nhiều hơn kèm theo đó là sự cải thiện về năng lực làm việc, quản lí, cũng như quá trình liên kết mạnh mẽ hơn giữa các tổ chức tài chính sẽ giúp cho việc xem xét, đánh giá những khoản đầu tư trong nền kinh tế được toàn diện, xác định được những khoản đầu tư hiệu quả nhất. Nguồn vốn tài trợ thông qua mạng lưới rộng khắp của các tổ chức tài chính sẽ được chu chuyển đến những khoản đầu tư hiệu quả này, nhờ vậy đảm bảo khả năng sử dụng tối đa các nguồn lực có sẵn từ các chủ thể trong nền kinh tế cho tăng trưởng kinh tế.

Patrick (1966) đã phát triển ý tưởng "cung - đi trước" và "cầu - theo sau" liên quan đến phát triển tài chính và đây cũng là những căn cứ lý thuyết quan trọng cho những nghiên cứu tiếp sau. Ý tưởng "cung - đi trước" nói đến vai trò đầu vào của các tổ chức tài chính trong việc thực hiện chức năng chuyển dịch nguồn lực giữa các khu vực trong nền kinh tế. Ở đây, do được chuyên môn hóa và cải thiện khả năng quản lí cũng như thành thạo nghiệp vụ, các tổ chức trung gian đáp ứng đầy đủ, chính xác, kịp thời với nhu cầu vốn của các khu vực trong nền kinh tế, cũng như chu chuyển nguồn vốn từ các ngành truyền thống không tăng trưởng như nông nghiệp, công nghiệp nặng, khai khoáng... sang các ngành hiện đại với khả năng tăng trưởng cao hơn như công nghệ thông tin và các lĩnh vực dịch vụ. Quan điểm này tương đồng với ý tưởng của Gurly và Shaw (1955), GoldSmith (1969), những học giả này cho rằng phát triển tài chính mà cụ thể là sự mở rộng, hoàn thiện của thị trường tài chính sẽ thúc đẩy tăng trưởng kinh tế bằng cách huy động nguồn vốn tiết kiệm để tài trợ cho những khoản đầu tư một cách hiệu quả nhất. Về ý tưởng "cầu - theo sau" có thể hiểu là khi có sự phát triển tài chính, các sản phẩm tài chính như các khoản vay, tiền gửi, bảo hiểm... và các dịch vụ tài chính như môi giới, xếp hạng sẽ đa dạng hơn về cả khía cạnh giá trị và thời hạn cũng như tăng độ tin cậy, phù hợp với những đòi hỏi khác nhau của những chủ thể trên thị trường. Điều này thúc đẩy các chủ thể tham gia vào nền kinh tế nhiều hơn với cả vai trò cung cấp vốn hay sử dụng vốn, nhờ vậy mà 
các nguồn vốn trong nền kinh tế được khai thác tối đa, góp phần gia tăng tốc độ tăng trưởng kinh tế. Ủng hộ cho quan điểm này, Mckinnon (1973) và Shaw (1973) cho rằng những biện pháp hạn chế của chính phủ can thiệp vào hệ thống ngân hàng làm ảnh hưởng tiêu cực đến sự phát triển tài chính như áp dụng trần lãi suất, yêu cầu dự trữ bắt buộc cao và các chương trình tín dụng chỉ định sẽ làm giảm tính linh hoạt, đa dạng của các sản phẩm, dịch vụ tài chính, gây tồn đọng vốn, do đó tác động bất lợi đến tốc độ tăng trưởng kinh tế.

Hầu hết các nghiên cứu đã tiến hành kiểm nghiệm sự ảnh hưởng và vai trò của phát triển tài chính lên tăng trưởng kinh tế là đều dựa trên các khung lý thuyết nền tảng là lý thuyết tăng trưởng kinh tế Tân cổ điển và các lý thuyết tăng trưởng nội sinh. Trong trường phái lý thuyết tăng trưởng nội sinh, GreenWood và Jovanovic (1990) đề cao tác động tích cực của phát triển tài chính đối với tăng trưởng kinh tế khi cho rằng sự cải thiện về chất lượng trong hoạt động của các trung gian tài chính sẽ góp phần tạo ra tỷ suất sinh lợi cao hơn, thu hút nhiều hơn những nhà đầu tư tham gia vào thị trường, cung cấp nguồn vốn cho các khu vực của nền kinh tế. Tương tự, Bencivenga và Smith (1991) nhận định rằng sự phát triển tài chính thể hiện qua việc đa dạng hóa các sản phẩm, dịch vụ tài chính đã cho phép các chủ thể trong nền kinh tế dùng những khoản tiết kiệm của mình để đầu tư vào các sản phẩm cũng như sử dụng các dịch vụ tài chính phù hợp với tỷ suất sinh lợi đòi hỏi. Bên cạnh đó, sự gia tăng về số lượng các sản phẩm tài chính cũng cho phép những nhà đầu tư đa dạng hóa danh mục của họ để giảm thiểu rủi ro, gắn liền với nhu cầu về tính thanh khoản, nhờ vậy thu hút nhiều hơn những nguồn lực để đầu tư phát triển kinh tế.

King và Levine (1993a) tìm thấy kết luận rằng mức độ phát triển tài chính càng cao thì tương quan có ý nghĩa thống kê và vững chắc với mức độ tăng trưởng kinh tế nhanh chóng ở hiện tại và cả trong tương lai nhờ vào khả năng tích lũy vốn vật chất và cải thiện tính hiệu quả của nền kinh tế. Từ các kết quả này, hai nhà nghiên cứu kết luận rằng mối quan hệ giữa phát triển tài chính và tăng trưởng kinh tế không chỉ là sự tương quan tạm thời mà phát triển tài chính là nhân tố dẫn dắt quan trọng cho sự tăng trưởng kinh tế. 
Mối quan hệ tương quan thuận giữa phát triển tài chính và tăng trưởng kinh tế được ủng hộ mạnh mẽ hơn bởi các nghiên cứu của các học giả trong giai đoạn thế kỷ 20 như Levine (1997), Levine và Zervos (1998) khi họ tìm thấy rằng mức độ phát triển tài chính là một chỉ báo tốt để dự báo cho tăng trưởng kinh tế trong tương lai. Levine và Zervos (1998) dùng phương pháp hồi quy trên dữ liệu chéo của 41 quốc gia trong giai đoạn 1976-1993 và kết quả cho thấy rằng thị trường chứng khoán có mối tương quan tích cực lên thành quả hoạt động kinh tế thực, và mối tương quan này đặc biệt mạnh mẽ hơn tại các nước đang phát triển. Hai nhà nghiên cứu này thậm chí còn chỉ ra rằng các thị trường cổ phiếu phát triển tốt có thể cung cấp nhiều loại hình dịch vụ tài chính còn tốt hơn hệ thống ngân hàng, cải thiện khả năng của nền kinh tế trong việc huy động vốn và đa dạng hóa để giảm thiểu rủi ro, do đó cung cấp thêm động lực và sự thúc đẩy cho đầu tư và tăng trưởng kinh tế còn mạnh mẽ hơn so với tác động này từ hệ thống ngân hàng. Từ đó họ kết luận rằng "sự phát triển của thị trường chứng khoán giải thích cho mức độ tăng trưởng kinh tế trong tương lai”. Tuy nhiên kết luận này được tìm thấy cách nay khá lâu và dựa trên kỹ thuật hồi quy thời kỳ đó còn lạc hậu là hồi quy trên dữ liệu chéo, nên đây cũng chính là vấn đề bị phê bình nhiều trong các nghiên cứu của thời kỳ sau.

Levine là học giả có nhiều nghiên cứu về chủ đề phát triển tài chính và tăng trưởng kinh tế công bố trên các tạp chí hàng đầu. Trong Levine (1997), ông đã giải thích chi tiết và rõ ràng hệ thống tài chính tác động thế nào đến tăng trưởng kinh tế, và bản thân nó chịu ảnh hưởng ngược lại từ tăng trưởng kinh tế ra sao. Dùng phương pháp tiếp cận chức năng để tìm hiểu vai trò của hệ thống tài chính đối với tăng trưởng kinh tế, ông cho rằng các chi phí để tìm kiếm thông tin và chi phí giao dịch đã khuyến khích sự hiện diện của các thị trường tài chính và các định chế tài chính. Định chế tài chính và thị trường tài chính trong quá trình thực hiện các chức năng của chúng đã sử dụng nguồn lực để tìm kiếm các dự án khả thi, xem xét và giám sát các nhà quản lý, có những biện pháp để quản trị rủi ro và giúp cho các giao dịch được tiến hành thuận lợi hơn. Ông nhấn mạnh thêm rằng nếu mô hình phân tích vai trò của các chứng khoán đối với việc phân bổ rủi ro một cách tối ưu của Arrow (1964) bổ sung thêm 
điều kiện giả định là không có chi phí giao dịch và chi phí thông tin thì lúc đó mới không cần có hệ thống tài chính. Lập luận này của Levine cho thấy ông đề cao ảnh hưởng tích cực của phát triển hệ thống tài chính đến tăng trưởng kinh tế bởi vì ông cho rằng các thị trường tài chính và định chế tài chính có thể giúp cải thiện các rắc rối gây ra bởi chi phí giao dịch và chi phí thông tin. Trên nền tảng phát triển tiếp từ nhiều tài liệu nghiên cứu trước về tài chính và tăng trưởng, Levine (1997) cụ thể hóa năm chức năng của hệ thống tài chính đó là:

$\checkmark$ Tạo thuận lợi cho các giao dịch, phòng ngừa rủi ro, đa đạng hóa đầu tư, chia sẻ rủi ro giữa các đối tượng tham gia thị trường.

$\checkmark$ Phân bổ các nguồn lực

$\checkmark$ Giám sát các nhà quản lý và kiểm soát hoạt động các doanh nghiệp

$\checkmark$ Huy động tiết kiệm

$\checkmark$ Tạo thuận lợi cho việc trao đổi hàng hóa và dịch vụ.

Thông qua năm chức năng trên, Levine giải thích rằng sự phát triển tài chính tác động đến tăng trưởng của nền kinh tế thông qua hai kênh truyền dẫn là tích lũy vốn và đổi mới công nghệ. Với kênh truyền dẫn là tích lũy vốn, sự phát triển của hệ thống tài chính ảnh hưởng đến sự tăng trưởng đều đặn của nền kinh tế bằng cách tác động đến tỷ lệ hình thành vốn thông qua sự thay đổi tỷ lệ tiết kiệm, hoặc tái phân bổ tiết kiệm giữa các lĩnh vực khác nhau làm gia tăng vốn một cách hiệu quả. Còn đối với kênh truyền dẫn là đổi mới công nghệ, sự phát triển của hệ thống tài chính làm thay đổi tốc độ đổi mới công nghệ.

Về sau, các nhà nghiên cứu còn sử dụng các kỹ thuật ước lượng kết quả hồi quy khác nhau như Arestis và Demetriades (1997) áp dụng phân tích nghiệm đơn vị và phương pháp ước lượng VAR trên mẫu gồm 2 nước là Mỹ và Đức, tìm thấy kết quả là có mối quan hệ dương giữa thu nhập thực bình quân đầu người với sự phát triển của hệ thống ngân hàng. Levine (2005) nghiên cứu và kết luận rằng các quốc gia có hệ thống ngân hàng và thị trường tài chính thực hiện chức năng tốt hơn thì nền kinh tế quốc gia đó tăng trưởng nhanh hơn. Phát triển tài chính tác động đến sự tăng trưởng kinh tế thông qua cơ chế làm giảm bớt những khó khăn trở ngại mà những 
điều kiện hạn chế tài chính từ bên ngoài gây ra cho các doanh nghiệp, nhờ đó mở rộng và phát triển các ngành sản xuất. Xu (2000) tìm thấy bằng chứng mạnh mẽ rằng sự phát triển tài chính thông qua các kênh đầu tư thì có ảnh hưởng tích cực lên tăng trưởng kinh tế. Nguyên nhân là do khi có sự phát triển tài chính tức là sự cải thiện về số lượng cũng như chất lượng các trung gian tài chính, những trung gian này sẽ có điều kiện để thu thập cũng như phân tích thông tin thị trường một cách chính xác hơn, nhờ đó nguồn ngân quỹ thông qua các trung gian tài chính sẽ được phân bổ tới những khu vực sử dụng hiệu quả nhất, làm tăng hiệu quả đầu tư và thúc đẩy tăng trưởng kinh tế. Johannes và cộng sự (2011) tìm thấy mối quan hệ tích cực dài hạn giữa phát triển tài chính và tăng trưởng kinh tế khi nghiên cứu dữ liệu chuỗi thời gian về Cameroon giai đoạn 1970-2005. Kết luận tương tự cũng tìm thấy trên mẫu về Cameroon trong nghiên cứu của Puatwoe và Piabuo (2017) với phương pháp ARDL. Shun-Jen và cộng sự (2013) cho thấy rằng các biến đại diện cho phát triển tài chính thì có tác động định hướng cho tăng trưởng kinh tế ở một vài nước Châu Á, đặc biệt là Trung Quốc. Sử dụng phương pháp ARDL trên mẫu nghiên cứu về Ấn Độ trong giai đoạn 19822012, Sehrawat và Giri (2014) tìm thấy kết quả ủng hộ lập luận về tác động tích cực của phát triển tài chính. Ủng hộ cho xu hướng quan điểm này gần đây hơn có kết quả thực nghiệm từ nghiên cứu của Durusu và cộng sự (2016) phân tích trên dữ liệu bảng 40 quốc gia giai đoạn 1989-2011; Zarrouk và cộng sự (2016) phân tích với mẫu là Các Tiểu vương quốc Ả Rập Thống Nhất (UAE) trong khoảng thời gian từ 19902012.

\subsubsection{Quan điểm hoài nghi về vai trò thúc đẩy của phát triển tài chính}

Trái với quan điểm của các tác giả đã nêu trên, Chandavarkar (1992) cho rằng chính phủ hoàn toàn không cần chú ý đến phát triển tài chính, không tìm thấy mối quan hệ nhân quả giữa tăng trưởng kinh tế và phát triển tài chính, thậm chí sự phát triển tài chính còn có thể gây hại cho tăng trưởng và phân phối thu nhập. Lucas (1988) lập luận rằng hệ thống tài chính chỉ có một vai trò rất nhỏ trong quá trình phát triển của khu vực sản xuất, hệ thống tài chính chỉ tạo ra cơ hội cho khu vực tư nhân tìm kiếm lợi nhuận hoặc họ sẽ bị thua lỗ khi tham gia trên thị trường tài chính. Shan và 
cộng sự (2001) thấy rằng trong mẫu nghiên cứu bao gồm chín nước OECD và Trung Quốc, phát triển tài chính không "dẫn" đến tăng trưởng kinh tế. Deidda và Fattouh (2002) đã xem xét mối quan hệ giữa phát triển tài chính và tăng trưởng kinh tế trên mẫu dữ liệu khá lớn gồm 119 quốc gia phát triển và đang phát triển giai đoạn 19601989 bằng phương pháp hồi quy ngưỡng của Hansen (2000) trên dữ liệu chéo. Bước đầu, các tác giả này tìm thấy rằng phát triển tài chính là nhân tố quyết định có ý nghĩa thống kê lên tăng trưởng kinh tế ở nhóm nước có thu nhập cao nhưng lại không đạt ý nghĩa thống kê ở nhóm nước có thu nhập thấp. Các tác giả này hoài nghi về mối quan hệ giữa phát triển tài chính và tăng trưởng kinh tế không phải là tuyến tính. Khan và Senhadji (2003) tìm thấy bằng chứng rằng hệ số hồi quy của biến đại diện cho phát triển tài chính lên tăng trưởng kinh tế là không có ý nghĩa thống kê; đồng thời cũng tìm thấy rằng trong khi sự phát triển tài chính có thể diễn ra một cách chậm chạp ở một số quốc gia, tăng trưởng kinh tế vẫn gia tăng nhanh hơn, do đó hai nhà nghiên cứu này kết luận không có sự ảnh hưởng từ phát triển tài chính lên tăng trưởng kinh tế. Tương tự, Andersen và Tarp (2003) kết luận rằng không có bằng chứng rõ ràng về mối quan hệ giữa tài chính và phát triển kinh tế.

Số lượng các nghiên cứu thực nghiệm theo xu hướng quan điểm này không nhiều; tuy nhiên từ những hoài nghi của nhóm các nhà nghiên cứu này rằng liệu phát triển tài chính có thực sự thúc đẩy cho tăng trưởng kinh tế hay không đã đặt ra tiền đề để các nghiên cứu thực nghiệm tiếp nối làm rõ vấn đề hơn khi chỉ ra rằng phát triển tài chính ảnh hưởng tích cực lên tăng trưởng kinh tế nhưng tác động của nó lại có thể đổi chiều thành ảnh hưởng tiêu cực lên tăng trưởng khi nền kinh tế phát triển hệ thống tài chính quá mức.

\subsubsection{Quan hệ phi tuyến giữa Phát triển tài chính và Tăng trưởng kinh tế}

Gần đây, sau khủng hoảng kinh tế toàn cầu 2008, xuất hiện những giải thích rõ ràng hơn về ảnh hưởng tiêu cực của sự phát triển hệ thống tài chính khi các nhà nghiên cứu chỉ ra rằng tác động của phát triển tài chính đến tăng trưởng kinh tế có thể không phải là tuyến tính, vì thế trong phạm vi nào đó, sự phát triển tài chính có 
ảnh hưởng tích cực lên tăng trưởng kinh tế nhưng vượt qua một giá trị ngưỡng, tác động phát triển tài chính sẽ thay đổi và gây ảnh hưởng tiêu cực lên tăng trưởng kinh tế (Cecchetti và Kharroubi, 2012, Arcand và cộng sự, 2012). Cecchetti và Kharroubi (2012) đã tìm thấy rằng khu vực tài chính càng phát triển nhanh thì tổng thể nền kinh tế lại tăng trưởng chậm lại. Họ lập luận rằng hiện tượng này xảy ra bởi vì khu vực tài chính đã cạnh tranh nguồn lực khan hiếm với phần còn lại của nền kinh tế, dẫn đến là tài chính càng tăng trưởng mạnh thì các ngành còn lại bị thiệt hại, cho nên nhìn chung không thúc đẩy tăng trưởng kinh tế. Quan điểm này được sự ủng hộ bởi nhiều bằng chứng thực nghiệm của các nhà nghiên cứu sau đó, cụ thể như:

Rioja và Valev (2004a) nghiên cứu trên dữ liệu bảng mẫu gồm 74 quốc gia phát triển và đang phát triển giai đoạn từ năm 1961 đến 1995 với dữ liệu tính trung bình theo chu kỳ 5 năm. Hai tác giả này sử dụng phương pháp Dynamic panel Generalized Method of Moments (GMM dành cho bảng động) là phương pháp ước lượng hồi quy hiện đại. Họ tìm thấy rằng phát triển tài chính tạo ra tác động tích cực lên tăng trưởng kinh tế chỉ khi nào nó đạt đến một mức độ nào đó, gọi là ngưỡng phát triển tài chính, mà dưới mức này thì tác động lại không chắc là tốt. Hai nhà nghiên cứu chia mẫu ra thành 3 nhóm nước có mức độ phát triển tài chính thấp, trung bình, và cao và kết quả thực nghiệm xác nhận rằng mức độ của phát triển tài chính giữ một vai trò quan trọng trong việc định hình ảnh hưởng của nó lên tăng trưởng kinh tế. Điều này có nghĩa là: đối với các quốc gia có mức độ phát triển tài chính trung bình, sự lớn mạnh của hệ thống tài chính có tác động tích cực lên tăng trưởng kinh tế; trong khi ở các nước đã có mức độ phát triển tài chính cao thì sự tác động này vẫn là tích cực nhưng mức độ ảnh hưởng thấp hơn. Tuy nhiên, đối với các nước có mức độ phát triển tài chính thấp thì vai trò thúc đẩy tăng trưởng kinh tế của hệ thống tài chính không đạt ý nghĩa thống kê. Trong cùng năm 2004, Rioja và Valev (2004b) lại tiếp tục công bố một nghiên cứu tương tự nhưng phân chia các nước trong mẫu theo thu nhập: cao, trung bình, thấp. Kết quả thực nghiệm cho thấy rằng ở các nền kinh tế thuộc nhóm nước thu nhập thấp thì không tìm thấy mối quan hệ có ý nghĩa giữa phát triển tài chính và tăng trưởng kinh tế; trong khi phát triển tài chính có tác động dương 
có ý nghĩa thống kê lên tăng trưởng của các nước có thu nhập trung bình, nhưng mức ý nghĩa lại yếu ở nhóm các nước có thu nhập cao. Hai tác giả đưa ra lý giải nguyên nhân của sự khác biệt này là do đối với những quốc gia có thu nhập thấp, sự phát triển tài chính chủ yếu góp phần gia tăng việc tích lũy vốn, trong khi ở những quốc gia có thu nhập trung bình và thu nhập cao, sự phát triển tài chính không chỉ giúp tích lũy vốn mà còn tăng cường sự tăng trưởng năng suất dựa trên việc phân bổ vốn vào lĩnh vực $\mathrm{R} \& \mathrm{D}$, nhờ vậy mà thúc đẩy tăng trưởng kinh tế một cách mạnh mẽ hơn nhưng các tác giả lại không lý giải được vì sao mức ý nghĩa thống kê lại yếu trong nhóm các nước có thu nhập cao.

Shen và Lee (2006) nghiên cứu dữ liệu bảng trên mẫu gồm 48 nước phát triển và đang phát triển với khoảng thời gian rộng hơn (1976-2001) cũng tìm thấy kết quả về mối quan hệ phi tuyến tính giữa phát triển tài chính và tăng trưởng kinh tế, mối quan hệ dạng chữ $\mathrm{U}$ ngược của hai đại lượng này, theo các tác giả hàm ý rằng mức độ phát triển tài chính càng cao thì sẽ có khuynh hướng gây cản trở tăng trưởng kinh tế. Ưu điểm của nghiên cứu này là nỗ lực đo lường sự phát triển tài chính trên cả hai khía cạnh là biến số thể hiện thị trường chứng khoán và biến số thể hiện hệ thống ngân hàng. Tuy nhiên, kết quả nghiên cứu này bị hoài nghi về tính vững của kết luận bởi vì hai tác giả này sử dụng phương pháp ước lượng Pooled OLS trên dữ liệu bảng. Việc sử dụng phương pháp Pooled OLS ở đây có nhược điểm là khó có thể thỏa năm giả định cần thiết. Ngoài ra, các nhà nghiên cứu này cũng nhận thấy rằng mối quan hệ phi tuyến dạng chữ $U$ ngược này thì yếu khi đo lường sự phát triển tài chính dựa trên mức độ phát triển của hệ thống ngân hàng.

Cùng ý tưởng với các tác giả trên, Ergungor (2008) nghiên cứu 46 nước phát triển và đang phát triển cũng trên dữ liệu chéo (lấy trung bình từ năm 1980-1995) bằng phương pháp mới hơn là 2SLS kèm xử lý phương sai thay đổi để đạt tính vững của ước lượng. Mối quan hệ phi tuyến tính giữa phát triển tài chính và tăng trưởng kinh tế được tìm thấy. 
Loayza và Ranciere (2006) phân biệt tác động ngắn hạn và dài hạn của phát triển tài chính đối với tăng trưởng kinh tế bằng cách sử dụng dữ liệu hàng năm trong giai đoạn 1960 - 2000 cho 75 quốc gia. Họ dùng mô hình ECM cho dữ liệu bảng (Error-correction model) để ước lượng theo phương pháp Pooled Mean Group (gộp trung bình nhóm). Kết quả là tồn tại mối quan hệ dương đạt ý nghĩa thống kê trong dài hạn giữa phát triển tài chính và tăng trưởng kinh tế, tuy nhiên trong ngắn hạn mối quan hệ này lại là âm đạt ý nghĩa thống kê. Họ cho rằng tác động âm trong ngắn hạn có thể là do tính không đồng nhất trong mẫu các quốc gia và do sự biến động cao của chu kì kinh tế. Mặc dù vậy, họ không đồng thuận với giả thuyết rằng có một tác động không đơn điệu của độ sâu tài chính lên tăng trưởng kinh tế.

Cũng nghiên cứu về tác động của phát triển tài chính lên tăng trưởng và phân chia các nước theo thu nhập nhưng kết quả nghiên cứu của De Gregorio và Guidotti (1995), Huang và Lin (2009) lại khác biệt. Họ tìm thấy rằng tác động dương của phát triển tài chính đến tăng trưởng kinh tế ở nhóm các nước có thu nhập thấp và thu nhập trung bình thì có ý nghĩa thống kê cao hơn so với nhóm nước thu nhập cao. Huang và Lin (2009) xem xét một mẫu 71 quốc gia có thu nhập cao và thu nhập thấp giai đoạn 1960 - 1995, dùng phương pháp hồi quy ngưỡng với biến công cụ nhưng trên dữ liệu chéo. Dùng biến công cụ là một phương pháp tốt để xử lý nội sinh nhưng tác giả chỉ làm được trên dữ liệu chéo, vì thế tác giả lấy giá trị trung bình từ 1960-1995. Việc lấy số trung bình duy nhất trong một khoảng thời gian dài như vậy đã làm triệt tiêu các biến động cần quan sát trong giai đoạn này.

Vấn đề nảy sinh ở đây chính là sự mâu thuẫn trong các kết luận tìm thấy. Khan và Senhadji (2003); Chuah và Thai (2004) đã nêu rằng những kết luận dựa trên việc phân tích dữ liệu chéo là không đáng tin cậy và vi phạm những vấn đề về kinh tế lượng bởi vì những kết quả theo phương pháp này là rất nhạy cảm đối với mẫu các quốc gia được chọn: sẽ là không thích hợp khi kết luận chung cho tất cả các quốc gia khác nhau như một thể đồng nhất. Bên cạnh đó, việc chỉ sử dụng dữ liệu chéo đã không khai thác được ý nghĩa của sự biến động theo thời gian của dữ liệu. Vấn đề về quan hệ nhân quả không được giải quyết một cách cụ thể trong một số nghiên cứu dữ 
liệu chéo. Ngoài ra, việc sử dụng biến công cụ là không thể giải quyết được vấn đề nội sinh khi dữ liệu được được tính trung bình qua thời gian dài (Ericsson và cộng sự, 2001). Dũ liệu chuỗi thời gian cũng không giải quyết những rắc rối này (Christopoulos và Tsionas, 2004). Các vấn đề trên đòi hỏi cải tiến phương pháp tiếp cận dữ liệu, do đó các nhà nghiên cứu về sau đa số thực hiện trên dữ liệu bảng.

Cecchetti và Kharroubi (2012) nghiên cứu trên dữ liệu bảng của 50 quốc gia phát triển và nền kinh tế mới nổi giai đoạn 1980-2009 với phương pháp Pooled OLS nhưng có xử lý robust standard errors. Kết quả tìm thấy là tác động của sự phát triển khu vực tài chính lên tăng trưởng sản lượng có dạng chữ U ngược. Tín dụng dành cho khu vực tư nhân - một chỉ số đại diện cho sự phát triển tài chính -vượt quá 90\% GDP thì sự phát triển sẽ trở thành lực cản đối với tăng trưởng kinh tế. Nguyên nhân được các tác giả này giải thích là do quá tập trung cho sự phát triển tài chính, cụ thể ở đây là sự gia tăng quá mức số lượng các ngân hàng trong hệ thống tài chính, sẽ gây nên sự cạnh tranh về các nguồn lực bao gồm cả nguồn vốn, nhân lực, khoa học kĩ thuật giữa khu vực tài chính với những thành phần còn lại của nền kinh tế, dẫn đến sự thiếu hụt nguồn lực cho các lĩnh vực sản xuất, kết quả cuối cùng là sự đi xuống của toàn nền kinh tế bộ.

Tác động phi tuyến cũng được ghi nhận bởi Arcand và cộng sự (2012). Sử dụng nhiều bộ dữ liệu khác nhau theo quốc gia và theo ngành, và phương pháp ước lượng bán tham số (semi-parametric estimations), kết quả cho thấy mối tương quan âm xuất hiện giữa phát triển tài chính và tăng trưởng kinh tế khi tỷ lệ tín dụng tư nhân trên GDP vượt quá $110 \%$ đối với các quốc gia có thu nhập cao, khi đó phát triển tài chính lại gây ra tác động phá hủy đối với nền kinh tế. Những học giả này cho rằng tác động tiêu cực của việc "quá nhiều tài chính" là do sự phát triển quá mức của khu vực tài chính sẽ dẫn tới việc phân bổ sai các nguồn lực trong nền kinh tế, chủ yếu đầu tư vào khu vực tài chính mà bỏ quên những lĩnh vực khác, ngoài ra sự phát triển tài chính quá mức có thể dẫn đến sự tăng trưởng tín dụng một cách nhanh chóng, mất kiểm soát là nguyên nhân gây bất ổn kinh tế vĩ mô, nguy cơ cho một cuộc khủng hoảng tài chính. 
Ngoài hai nghiên cứu nổi bật nêu trên của Arcand và cộng sự (2012), Cecchetti và Kharroubi (2012), có nhiều nghiên cứu thực nghiệm khác cũng ủng hộ cho lập luận về mối quan hệ phi tuyến giữa phát triển tài chính và tăng trưởng kinh tế. Law, Azman-Saini, và Ibrahim (2013) xác định một ngưỡng giới hạn trong mối quan hệ giữa tài chính và tăng trưởng tạo ra bởi chất lượng thể chế quốc gia. Sử dụng dữ liệu trong giai đoạn 1980-2008, kết quả nghiên cứu của họ tìm thấy rằng khi thể chế vượt qua ngưỡng giới hạn thì phát triển tài chính mới có tác dụng thúc đẩy sự tăng trưởng kinh tế.

Cũng giải quyết những câu hỏi tương tự như Loayza và Ranciere (2006) nhưng sử dụng cách tiếp cận khác hơn, Rousseau và Wachtel (2011) dùng dữ liệu bảng chứng minh rằng tác động của độ sâu tài chính đối với tăng trưởng trong giai đoạn 1990-2004 thì yếu hơn so với giai đoạn 1960-1989. Họ thừa nhận rằng, sự tăng trưởng nhanh chóng của tín dụng và sự lan nhanh của tự do hóa trong những năm chín mươi dẫn đến áp lực lạm phát, đồng thời làm suy yếu hệ thống ngân hàng dẫn đến gây ra cuộc khủng hoảng tài chính, điều này chính là nguyên nhân cho "sự biến mất hiệu ứng tích cực của phát triển tài chính". Từ góc độ chính sách, cần phải có những cải cách trong khu vực tài chính cùng với xây dựng các quy định sao cho phù hợp với độ sâu tài chính.

Năm 2014 tập trung nhiều công trình nghiên cứu liên quan đến quan hệ phi tuyến giữa tài chính và tăng trưởng. Law và Singh (2014) cũng đặt ra vấn đề liệu phát triển tài chính có gây cản trở đối với tăng trưởng kinh tế sau khi sự phát triển tài chính của một quốc gia đạt đến một ngưỡng nhất định hay không. Sử dụng phương pháp hồi quy ngưỡng với bảng động gồm 87 quốc gia phát triển và đang phát triển giai đoạn 1980 - 2010, họ tìm thấy một giá trị ngưỡng của tín dụng tư nhân là 4,482, tức là $88 \%$ so với GDP, cung tiền mở rộng M3 có giá trị ngưỡng là 4,514\%, tức là $91 \%$ GDP, tín dụng trong nước là 4,595, tức là 99\% GDP. Khi vượt qua các giá trị ngưỡng này, sự phát triển hơn nữa của hệ thống tài chính trở nên không có lợi cho nền kinh tế. 
Owen và Temesvary (2014) đóng góp vào chủ đề này bằng kết quả thực nghiệm chứng minh rằng ảnh hưởng của tài chính ngân hàng lên tăng trưởng thì không đồng nhất giữa các quốc gia và giữa các loại hình tín dụng ngân hàng (tức là ngân hàng nội địa và ngân hàng nước ngoài). Tính không đồng nhất này được nắm bắt thông qua việc phân nhóm các quốc gia lại với nhau dựa trên phân phối có điều kiện của tốc độ tăng trưởng. Cụ thể, họ phát hiện ra rằng các đặc tính quốc gia như mức độ phát triển của thị trường chứng khoán, mức độ chặt chẽ của các quy định pháp luật, và sự phát triển của khu vực ngân hàng biến động đáng kể giữa các quốc gia và ảnh hưởng đến hiệu quả thúc đẩy của tín dụng ngân hàng lên tăng trưởng. Kết luận này cũng tương đồng với những nhận định của Rajan và Zingales (1998) khi hai tác giả này tìm thấy rằng phát triển tài chính làm giảm chi phí của các nguồn tài trợ bên ngoài cho doanh nghiệp, do đó ở các nước càng phát triển hệ thống tài chính thì những ngành phụ thuộc nhiều vào nguồn tài trợ bên ngoài sẽ càng đạt thành quả tốt hơn.

Có thể thấy, nghiên cứu về mối quan hệ giữa tài chính và tăng trưởng tìm thấy nhiều kết luận phức tạp và không hẳn là đồng thuận với nhau. Trong nỗ lực tìm kiếm sự gỡ rối cho các quan điểm phức tạp nói trên, Beck, Degryse và Kneer (2014) tìm hiểu tác động từ qui mô và mức độ của các trung gian tài chính lên tăng trưởng GDP bình quân đầu người và sự biến động của tăng trưởng, với mẫu quan sát 77 quốc gia trong giai đoạn 1980-2007. Họ thấy rằng trong dài hạn, sự phát triển của các trung gian tài chính làm tăng tốc độ tăng trưởng GDP và làm giảm sự biến động của tăng trưởng. Quan trọng hơn, trong trung hạn, một khu vực tài chính phát triển mạnh mẽ ở các quốc gia có thu nhập cao sẽ kích thích tăng trưởng kinh tế nhưng cái giá phải đánh đổi là mức độ biến động cao của nền kinh tế; trong khi đó ở các quốc gia có thu nhập thấp thì hoạt động của khu vực tài chính lại giúp bình ổn nền kinh tế.

Samargandi và cộng sự (2015) sử dụng mô hình tự hồi quy có độ trễ (ARDL) để khắc phục vấn đề tính không đồng nhất trong dữ liệu bảng, xem xét ảnh hưởng của phát triển tài chính đến tăng trưởng cả trong dài hạn lẫn trong ngắn hạn. Theo các tác giả này lập luận, hệ thống tài chính của các quốc gia phát triển tiên tiến thì có khả 
năng hỗ trợ một cách hiệu quả cho sự huy động vốn trong các trạng thái giữa thặng dư và thâm hụt, điều này cuối cùng sẽ dẫn đến sự tăng trưởng kinh tế. Trái lại, đối với các nước đang phát triển với những đặc điểm truyền thống là nền kinh tế kém phát triển hơn, hệ thống tài chính hoạt động kém hiệu quả hơn, quy mô và mức độ hiệu quả của các trung gian tài chính thấp hơn cho nên mối quan hệ giữa tài chính và tăng trưởng là không xác định được (Kar, Nazlioglu, và Agir, 2011). Vì vậy, họ chọn mẫu nghiên cứu là 52 quốc gia có thu nhập trung bình. Kết quả nghiên cứu của họ một lần nữa xác nhận mối quan hệ giữa tài chính và tăng trưởng không nhất thiết là tuyến tính cả trong dài hạn lẫn trong ngắn hạn. Hơn thế nữa, kết quả còn khẳng định tài chính không chỉ tác động dương đến tăng trưởng như các quan điểm trước đây, mà khi vượt qua giá trị ngưỡng thì sự phát triển tài chính tạo ra một tác động âm lên tăng trưởng của nền kinh tế.

\subsubsection{Nghiên cứu thực nghiệm ở các nước châu Á}

Số lượng các nghiên cứu thực nghiệm công bố chính thức về chủ đề này trên mẫu các nước châu Á là khá ít ỏi. Ang (2009) nghiên cứu vai trò của các trung gian tài chính đối với sự tăng trưởng kinh tế của Malaysia. Tác giả nhận thấy càng phát triển tài chính thì càng thúc đẩy tăng trưởng kinh tế và điều này có ý nghĩa thống kê với nền kinh tế Malaysia - một nền kinh tế tăng trưởng nhanh và có nhiều cải cách đối với khu vực tài chính. Tác giả cũng cho thấy một số can thiệp của chính phủ gây ra tác động cản trở đối với phát triển tài chính; trái lại các chính sách như kiểm soát lãi suất, tăng dự trữ bắt buộc, các chương trình tín dụng trực tiếp thì lại tác động tích cực đối với phát triển tài chính. Theo tác giả, cơ chế tương tác giữa phát triển tài chính và tăng trưởng kinh tế cùng với sự đổi mới phát triển tài chính sẽ dẫn đến tăng sản lượng của nền kinh tế thông qua thúc đẩy tiết kiệm tư nhân và đầu tư tư nhân.

Jeanneney và cộng sự (2006) nghiên cứu trên dữ liệu về Trung Quốc giai đoạn 1993-2001, sử dụng phương pháp system - GMM đã tìm thấy kết luận là sự phát triển của khu vực tài chính có tác động dương đến tăng trưởng sản lượng của nền kinh tế. Kết luận này tương đồng với kết quả trong nghiên cứu của Wong và Zhou (2010) 
dùng phương pháp hồi quy dữ liệu bảng trên mẫu 3 quốc gia châu Á là Hong Kong, China, Nhật Bản so sánh với Mỹ và Anh thời kỳ trước khủng hoảng (1988-2008).

Estrada và cộng sự (2010) nghiên cứu mối liên hệ giữa phát triển tài chính và tăng trưởng kinh tế tại các nước châu Á đang phát triển trên mẫu gồm 116 quốc gia, trong đó có 22 nước đã là thành viên của Ngân hàng Phát triển châu Á (ADB) trong giai đoạn 1987-2008. Năm 1997-1998 bị loại ra khỏi mẫu quan sát vì lý do đây là khoảng thời gian xảy ra khủng hoảng tài chính châu Á. Dữ liệu được nghiên cứu theo từng giai đoạn 5 năm: 1987-1991, 1992-1996, 1999-2003, 2004-2008, tuy nhiên một số quốc gia dữ liệu bị hạn chế không thu thập được nên bảng dữ liệu không cân đối (unbalanced panel data). Điều này cũng góp phần làm hạn chế kết quả nghiên cứu. Các tác giả đưa ra kết luận rằng, đối với tất cả các thước đo tài chính đều tìm thấy mối tương quan tích cực có ý nghĩa thống kê của phát triển tài chính lên tăng trưởng GDP bình quân đầu người. Hơn thế nữa, kết quả các mô hình ước lượng đều cho thấy độ sâu tài chính càng lớn (thông qua đo lường bằng nợ thanh khoản - liquid liabilities) thì càng thúc đẩy tăng trưởng kinh tế. Hai thước đo còn lại là tín dụng của ngân hàng thương mại và quy mô vốn hóa của thị trường chứng khoán cũng đều thể hiện tác động tích cực của phát triển tài chính lên tăng trưởng kinh tế. Từ đó, các tác giả đề xuất rằng các nhà hoạch định chính sách cần ưu tiên nỗ lực làm tăng độ sâu tài chính trong tổng thể các chiến lược phát triển cân đối toàn nền kinh tế. Đặc biệt, theo các tác giả này, đối với các quốc gia châu Á đang phát triển thì hệ thống tài chính giữ một vai trò chính yếu, nhất là trong thời kỳ hậu khủng hoảng bởi vì nó giúp cải thiện hiệu quả đầu tư, đóng góp vào sự gia tăng sản lượng của nền kinh tế.

Singapore là một nước châu Á, xuất hiện trong mẫu nghiên cứu gồm 5 quốc gia Barbados, Jamaica, Singapore, Trinidad, và Tobago của Iyare và Moore (2011) giai đoạn 1960-2003. Các nhà nghiên cứu này dùng phân tích nhân quả Granger và kiểm định đồng tích hợp Johansen cũng tìm thấy kết quả về vai trò thúc đẩy tích cực của phát triển tài chính đối với tăng trưởng. Các kết quả tương đồng cũng xuất hiện trong nghiên cứu hiếm hoi về các quốc gia châu Á như Jalil và Feridun (2011) sử dụng dữ liệu về nền kinh tế Pakistan giai đoạn 1975-2008 với phương pháp ước lượng 
ARDL cùng với bound testing, hay nghiên cứu của Nisanci và cộng sự (2011) dùng hồi quy dữ liệu bảng cho mẫu 8 nước Bangladesh, Egypt, Indonesia, Iran, Malaysia, Nigeria, Pakistan và Turkey (1974-2007).

Đối với Việt Nam, Anwar và Nguyen (2011) nghiên cứu dữ liệu bảng số liệu 61 tỉnh thành của Việt Nam trong giai đoạn 1997-2006 để xem xét mối liên hệ giữa phát triển tài chính và tăng trưởng kinh tế. Dựa trên phân tích về lý thuyết tăng trưởng nội sinh, kết quả nghiên cứu này cho thấy phát triển tài chính đóng góp cho tăng trưởng kinh tế tại Việt Nam. Tỷ lệ tín dụng trên GPP (Gross Provincial Product) càng cao thì càng thúc đẩy tăng trưởng kinh tế. Khi thay thế các thước đo khác của mức độ phát triển tài chính, các tác giả cũng vẫn ủng hộ cho lập luận rằng càng phát triển tài chính càng có lợi. Bên cạnh đó, họ còn cho rằng tác động của dòng vốn đầu tư nước ngoài (FDI) lên tăng trưởng kinh tế sẽ càng mạnh mẽ hơn nếu nhiều nguồn lực được đầu tư hơn cho việc phát triển thị trường tài chính.

Việt Nam là một nền kinh tế nhỏ chưa thu hút nhiều sự quan tâm của thế giới nên các nghiên cứu trên bộ dữ liệu Việt Nam phần lớn được thực hiện dưới dạng các đề tài nghiên cứu nhỏ trong nước, thường dựa trên cơ sở mối quan hệ tuyến tính khi phân tích phát triển tài chính và tăng trưởng kinh tế, hoặc chỉ phân tích một cách độc lập một trong hai khía cạnh: sự phát triển của khu vực ngân hàng, sự phát triển của thị trường chứng khoán. Đa số các nghiên cứu không có dữ liệu với độ dài đủ để phân tích. Năm 2016, hai tác giả Hoàng Thị Phương Anh và Đinh Tấn Danh, đã nỗ lực bổ sung vào các nghiên cứu về chủ đề này bằng nghiên cứu thực nghiệm trong nước, sử dụng mô hình DOLS (Dynamic OLS) để xem xét mối quan hệ giữa phát triển tài chính và phát triển kinh tế. Sử dụng dữ liệu của 29 quốc gia trong khu vực châu Á từ năm 1996-2013, kết quả nghiên cứu thực nghiệm của các tác giả này cho thấy phát triển tài chính có tác động tích cực lên phát triển kinh tế và mối quan hệ này thì mạnh mẽ hơn tại các quốc gia có thu nhập cao. Ngoài ra, mối quan hệ giữa phát triển tài chính và phát triển kinh tế sẽ yếu đi nếu như mất cân đối giữa phát triển tài chính và tăng trưởng kinh tế. Thậm chí phát triển tài chính có thể làm giảm tăng trưởng kinh tế nếu tốc độ phát triển lĩnh vực tài chính nhanh hơn tốc độ tăng trưởng kinh tế. Tuy 
nhiên, do hạn chế về dữ liệu nên bài nghiên cứu này cũng chưa kiểm tra hết các nhân tố khác có tác động đến mối quan hệ tài chính và kinh tế. Các nghiên cứu thực nghiệm về mối quan hệ giữa phát triển tài chính và tăng trưởng kinh tế tại Việt Nam chưa được công bố quốc tế, ngoại trừ nghiên cứu của Anwar và Nguyen (2011). Chủ đề này trong bối cảnh thực tế của Việt Nam được đề cập chủ yếu về mặt lý luận như Phạm Minh Chính và Vương Quân Hoàng (2009), Vương Quân Hoàng (2010); Vương Quân Hoàng, Phạm Minh Chính và Trần Trí Dũng (2010). Trong một bài viết đáng chú ý gần đây phân tích về vai trò của hệ thống tài chính Việt Nam đối với tăng trưởng kinh tế giai đoạn 2016 -2020 của tác giả Trương Văn Phước (2017), hiện là Quyền Chủ tịch Ủy ban Giám sát Tài chính Quốc gia Việt Nam và là một trong 16 thành viên trong Tổ Tư vấn Kinh tế_nhiệm kỳ 2016-2021, ông khẳng định hệ thống tài chính, với vai trò huyết mạch của nền kinh tế, đòi hỏi phải phát triển ở mức độ sâu hơn, hiện đại hơn, song vẫn đảm bảo tính an toàn, lành mạnh trước những biến động của thị trường tài chính toàn cầu. Tuy nhiên các phân tích trong bài viết này cũng được trình bày dưới dạng lý luận, không phải là bằng chứng thực nghiệm.

\section{Khoảng trống nghiên cứu:}

Qua việc tổng lược các tài liệu nghiên cứu thực nghiệm trước đây có thể thấy rằng các nền kinh tế châu Á chưa thực sự được nghiên cứu đúng mức và đầy đủ mặc dù nơi đây có nhiều nền kinh tế mới nổi đang thu hút sự quan tâm của giới đầu tư thế giới. Mẫu nghiên cứu của các học giả tập trung nhiều vào các nền kinh tế châu Âu với đặc thù văn hóa-xã hội, kinh tế, chính trị không giống như các nước châu Á. Cho nên, các kết luận tìm thấy từ mẫu các nước châu Âu có thể không phù hợp để áp dụng tại các nước châu Á, cho các quốc gia có thể chế chính trị khác biệt như Trung Quốc, Việt Nam. Quan điểm của các nhà kinh tế học lẫn các chuyên gia tài chính thế giới về vai trò và ảnh hưởng của phát triển tài chính lên tăng trưởng kinh tế lại không thống nhất với nhau. Cả hai trường phái quan điểm về mối quan hệ giữa phát triển tài chính và tăng trưởng kinh tế đều có những bằng chứng hết sức thuyết phục nhưng xuất hiện nhiều quan điểm hoài nghi, trái chiều lẫn nhau. Quy mô và sự tăng trưởng của khối ngành tài chính trong nền kinh tế ảnh hưởng tích cực hay tiêu cực lên tăng 
trưởng kinh tế là vấn đề cần phải được kiểm định lại để có câu trả lời xác đáng hơn. Liệu có tồn tại một mức ngưỡng của sự phát triển tài chính mà nếu vượt qua mức này thì các lợi ích mà phát triển tài chính đem lại cho nền kinh tế sẽ bắt đầu giảm đi và các thiệt hại mà hệ thống tài chính gây ra bắt đầu tăng lên? Các nghiên cứu mới gần đây đặt ra vấn đề cần xem xét lại chính xác hơn tác động này có thực sự là luôn tích cực hay không. Điều này dẫn đến nhu cầu cần đánh giá lại vai trò của phát triển tài chính đối với tăng trưởng kinh tế trong bối cảnh hiện đại, cũng chính là một trong các khoảng trống nghiên cứu của luận án.

Hơn nữa, mức độ tác động của phát triển tài chính lên tăng trưởng kinh tế có sự khác biệt giữa nhóm nước khác nhau về mức thu nhập và trình độ phát triển (Deidda và Fattouh, 2002; Beck, Degryse và Kneer, 2014) cho thấy chính sách phát triển hệ thống tài chính cần phù hợp với bối cảnh của nền kinh tế. Quốc gia đang phát triển có những yếu tố thuận lợi nhưng cũng có những thách thức khó khăn, không giống với quốc gia đã có trình độ phát triển cao. Tuy nhiên các nghiên cứu trước đây chỉ thực nghiệm đơn lẻ với từng nhóm nước chứ chưa kết hợp so sánh để đề ra chính sách giải pháp thích hợp.

Sự mâu thuẫn trong các kết luận tìm thấy về mối quan hệ giữa phát triển tài chính và tăng trưởng kinh tế, sự thay đổi của bối cảnh thế giới sau khủng hoảng, cũng như sự quan tâm chưa đầy đủ về các nền kinh tế châu Á - trong đó có Việt Nam đã dẫn đến khoảng trống nghiên cứu và nhu cầu cần thiết làm sáng tỏ, kiểm định lại tác động thực sự của phát triển tài chính lên tăng trưởng kinh tế với mẫu dành cho các quốc gia châu Á, xem xét cả nhân tố thu nhập và những đặc thù của các nền kinh tế mới nổi và đang phát triển. Nghiên cứu này kỳ vọng đóng góp thêm cho học thuật những hiểu biết hơn về các nền kinh tế châu Á trong bối cảnh mới. 


\section{Kết luận chương 2}

Tóm lại, chương này tổng lược khung lý thuyết, khái niệm, và bằng chứng thực nghiệm liên quan đến tác động của phát triển tài chính đến tăng trưởng kinh tế. Các lý thuyết tăng trưởng kinh tế đều cho rằng vốn là thành tố quan trọng của tăng trưởng kinh tế dài hạn. Trên cơ sở nền tảng này, nhiều nhà nghiên cứu trên thế giới với các công trình nghiên cứu uy tín đã chỉ ra rằng sự phát triển của hệ thống tài chính ảnh hưởng tích cực đến tăng trưởng kinh tế. Tuy nhiên, thời gian gần đây, các nghiên cứu lại chỉ ra rằng trong phạm vi nào đó, sự phát triển tài chính có ảnh hưởng tiêu cực lên tăng trưởng kinh tế. Các nghiên cứu theo xu hướng phân tích mới là xác định mức ngưỡng phát triển tối ưu cho hệ thống tài chính sao cho thúc đẩy tăng trưởng kinh tế trong dài hạn, bởi vì quan điểm mới của các học giả là sự phát triển tài chính chỉ nên đạt đến mức độ nào đó. Khi vượt qua qua mức này thì các lợi ích mà phát triển tài chính đem lại cho nền kinh tế sẽ bắt đầu giảm đi và các thiệt hại mà hệ thống tài chính gây ra bắt đầu tăng lên. Tuy nhiên số lượng nghiên cứu thực nghiệm triển khai theo xu hướng mới này chưa đủ nhiều để mang tính thuyết phục cao. Không có mô hình nào hay lý thuyết nào tốt nhất cho mọi quốc gia, phù hợp nhất cho mọi thời kỳ. Chính những bất đồng và tranh luận đang tiếp diễn đã tạo ra các khoảng trống dành cho các nhà nghiên cứu tiếp tục thực nghiệm. Các lập luận và quan điểm khác nhau giữa các học giả cũng chính là một khoảng trống nghiên cứu tạo động lực cho việc thực hiện nghiên cứu của luận án này. 


\section{CHUOONG 3 PHƯƠNG PHÁP NGHIÊN CÚU}

Trên cơ sở khoảng trống nghiên cứu đã trình bày ở chương 2 , mục tiêu nghiên cứu của luận án là kiểm định các tác động của sự phát triển tài chính lên tăng trưởng kinh tế tại các quốc gia châu Á, từ đó đề xuất các giải pháp định hướng phát triển hệ thống tài chính cho các quốc gia châu Á hướng tới duy trì sự tăng trưởng kinh tế trong dài hạn.

Để thực hiện mục tiêu nghiên cứu nói trên, các câu hỏi nghiên cứu sau đây được xây dựng:

\subsection{Câu hỏi nghiên cứu và giả thuyết nghiên cứu}

Câu hỏi nghiên cứu 1): Giá trị nguỡng của mức độ phát triển tài chính là bao nhiêu?

Câu hỏi này sẽ đáp ứng mục tiêu nghiên cứu cụ thể thứ nhất là: xác định giá trị điểm chuyển tiếp (hay còn gọi là giá trị ngưỡng - threshold value) của phát triển tài chính trong mẫu cụ thể các quốc gia châu Á; làm rõ các kết luận còn gây nhiều tranh cãi cho đến ngày nay là: trong các nền kinh tế châu Á, liệu có thật sự xuất hiện điểm chuyển tiếp của phát triển tài chính hay không, mà khi vượt qua điểm này thì tác động của phát triển tài chính lên tăng trưởng kinh tế có sự thay đổi.

Luận án sử dụng 6 chỉ tiêu đo lường mức độ phát triển tài chính để có thể phản ánh đa diện thực trạng của hệ thống tài chính, đó là:

- Tín dụng dành cho khu vực tư nhân trên GDP;

- Tín dụng trong nước trên GDP;

- Nợ thanh khoản trên GDP;

Đây là ba chỉ tiêu phản ánh về mức độ phát triển của hệ thống ngân hàng, là thành phần chủ đạo trong hệ thống tài chính các nước châu Á. Ngoài ra, sự phát triển của thị trường tài chính - là bộ phận không thể tách rời của hệ thống tài chính các nước trong thời kỳ hiện đại - được thể hiện thông qua ba chỉ tiêu khác, bao gồm: 
- Quy mô vốn hóa của thị trường chứng khoán trên GDP

- Tỷ suất sinh lợi của thị trường chứng khoán

- Quy mô giao dịch của TTCK trên GDP

Vì vậy, câu hỏi nghiên cứu lớn nêu trên sẽ được triển khai cụ thể là:

Câu hỏi 1-1: Giá trị nguõng của tín dụng dành cho khu vục tư nhân tại các nuớc châu Á là bao nhiêu \% so với GDP?

Câu hỏi 1-2: Giá trị nguõng của tín dụng trong nuớc tại các nuớc châu Á là bao nhiêu \% so với GDP?

Câu hỏi 1-3: Giá trị nguõng của nợ thanh khoản tại các nước châu Á là bao nhiêu \% so với GDP?

Câu hỏi 1-4: Giá trị nguõng của quy mô vốn hóa thị truờng chưng khoán tại các nuớc châu Á là bao nhiêu \% so với GDP?

Câu hỏi 1-5: Tại điểm chuyển tiếp, tỷ suất sinh lợi của thị truờng chứng khoán các nước châu Á là bao nhiêu \%?

Câu hỏi 1-6: Giá trị nguỡng của quy mô giao dịch thị trương chứng khoán tại các nuoóc châu Á là bao nhiêu \% so với GDP?

Theo các nghiên cứu thực nghiệm trong thời gian gần đây được trình bày trong chương 2 , phát triển tài chính không chỉ tác động dương mà còn có thể gây ra tác động âm lên tăng trưởng của nền kinh tế tại các miền giá trị khác nhau của biến số đo lường sự phát triển tài chính. Nói cách khác, mối quan hệ giữa phát triển tài chính và tăng trưởng kinh tế là phi tuyến tính và xuất hiện giá trị ngưỡng, hay còn gọi là điểm chuyển tiếp, của phát triển tài chính mà khi vượt qua ngưỡng này, tác động gây ra bởi phát triển tài chính thay đổi so với trước đó như lập luận của Shen và Lee (2006), Ergungor (2008), Cecchetti và Kharroubi (2012), Arcand và cộng sự (2012), Law và Singh (2014). Do đó, giả thuyết nghiên cứu $\mathrm{H}_{1}$ được xây dựng là: 
Giả thuyết $\mathbf{H}_{1}$ Tồn tại một giá trị ngưỡng của phát triển tài chính, mà trước và sau giá trị ngưỡng này, tác động của phát triển tài chính lên tăng trưởng kinh tế có thay đổi.

Bên cạnh việc xác định mức giá trị ngưỡng đối với phát triển tài chính thông qua sáu chỉ tiêu cụ thể, luận án cũng kỳ vọng sẽ chi tiết hóa, làm rõ chiều tác động và mức độ ảnh hưởng cụ thể của nhân tố sự phát triển tài chính lên tăng trưởng kinh tế như các tài liệu nghiên cứu trước đã đề cập (Cecchetti và Kharroubi, 2012; Arcand và cộng sự, 2012; Law và Singh, 2014; Samargandi và cộng sự, 2015). Vì vậy, hai câu hỏi nghiên cứu cùng với giả thuyết nghiên cứu tiếp theo là:

Câu hỏi nghiên cúu 2) Trước giá trị ngương, Phát triển tài chính tác động như thế nào lên tăng trưởng kinh tế của các quốc gia châu Á?

Giả thuyết $\mathbf{H}_{2}$ : Trước giá trị ngưỡng, Phát triển tài chính tác động tích cực đến tăng trưởng kinh tế của các quốc gia châu Á

Câu hỏi nghiên cứu 3) Sau giá trị ngương, Phát triển tài chính tác động nhu thế nào lên tăng trương kinh tế của các quốc gia châu Á?

Giả thuyết $\mathbf{H}_{3}$ : Khi vượt qua giá trị ngưỡng thì Phát triển tài chính tác động tiêu cực lên tăng trưởng kinh tế của các quốc gia châu Á

Phân tích định lượng được sử dụng để kiểm định ba giả thuyết nghiên cứu nói trên, làm rõ khi hệ thống tài chính quốc gia ở các mức độ phát triển khác nhau thì tác động của phát triển tài chính lên tăng trưởng kinh tế như thế nào.

Từ kết quả thực nghiệm về mối quan hệ trong dài hạn của phát triển tài chính và tăng trưởng kinh tế, kết hợp với thực trạng tại các nước châu Á, tác giả của luận án thực hiện đề xuất các giải pháp về mặt chính sách để phát triển hệ thống tài chính hướng tới mục tiêu tăng trưởng kinh tế trong dài hạn.

\subsection{Dũ̃ liệu nghiên cứu}

Mẫu nghiên cứu gồm 33 quốc gia châu Á phát triển và đang phát triển trong giai đoạn 2004-2016. Khoảng thời gian phân tích này được lựa chọn vì những lý do sau đây: 
- Thứ nhất, trước năm 2008, không chỉ các nhà kinh tế học mà ngay cả các nhà hoạch định chính sách của các chính phủ đều tin tưởng rằng hệ thống tài chính càng phát triển cả chiều rộng lẫn chiều sâu sẽ là một tiền đề không thể thiếu nếu muốn đạt được tăng trưởng của nền kinh tế. Hơn thế nữa, đa số các nền kinh tế châu Á được phân loại là các nền kinh tế mới nổi. Các số liệu thống kê đã chỉ ra rằng, mặc dù hệ thống tài chính của các nước này đã phát triển khá mạnh mẽ trong những thập niên gần đây nhưng độ phát triển vẫn còn thấp so với các nền kinh tế đã phát triển (Sahay và cộng sự, 2015). Điều này hàm ý rằng các quốc gia châu Á vẫn cần phát triển hệ thống tài chính của họ thêm nữa để đạt sự tăng trưởng kinh tế như mong đợi. Tuy nhiên năm 2008 có một biến cố quan trọng là khủng hoảng tài chính thế giới, xuất phát ngay từ chính những nền kinh tế mạnh và có hệ thống tài chính đã phát triển đến độ phức tạp là Mỹ, sau đó lan rộng ra toàn cầu, và các quốc gia châu Á cũng không tránh khỏi bị ảnh hưởng và thiệt hại nghiêm trọng. Cuộc khủng hoảng này là một hồi chuông cảnh báo và đã đặt ra một câu hỏi chính đáng rằng: có phải hệ thống tài chính phát triển quá cao, quá nhiều sẽ gây ra rủi ro và tổn thương cho nền kinh tế hay không. Vì thế, tác giả luận án này lựa chọn khung thời gian nghiên cứu bao gồm giai đoạn trước, trong, và sau khủng hoảng 2008 để phân tích với kỳ vọng có thể rút ra bài học kinh nghiệm và hướng phát triển phù hợp cho các nước châu Á.

- Thư hai, đặc thù của phần lớn các nước trong mẫu nghiên cứu về châu Á là các nền kinh tế còn non trẻ và đang phát triển. Vì thế, trước năm 2004, dữ liệu về hệ thống tài chính của họ không được ghi nhận đầy đủ, hoặc họ chưa phát triển. Ngoài ra, một trong các biến chính của bài nghiên cứu này là Tỷ số Nợ thanh khoản trên GDP (Liquid liabilities to GDP) được thu thập từ bộ dữ liệu Global Financial Development Data của Ngân hàng Thế giới (World Bank) cho đến nay cũng chỉ có dữ liệu đến năm 2016. Đây là những lý do khách quan khiến cho khung thời gian nghiên cứu chỉ đến năm 2016.

Bên cạnh đó, mặc dù châu Á gồm 50 quốc gia nhưng một số nước châu Á do điều kiện khách quan không thể tiếp cận số liệu nên không đưa vào mẫu quan sát. Russia thường được xem xét khi đề cập đến các nền kinh tế thuộc châu Âu. Tuy nhiên 
trong thực tế, Russia là quốc gia có vùng lãnh thổ trải dài châu Á và châu Âu, trong đó chiếm toàn bộ phần phía Bắc châu Á. Về mặt địa lý, Russia được công nhận thuộc châu Á, do đó cũng được đưa vào mẫu nghiên cứu của luận án này. Ngoài ra, khi phân tích về mức độ phát triển tài chính trên phương diện thị trường tài chính, mẫu phải loại trừ trường hợp Brunei, Maldives, Cambodia, Myanmar, Taijikistan vì các quốc gia này không có thị trường chứng khoán; và loại trừ Armenia, Bangladesh, Kuwait, Kyrgyz Republic, Nepal, Mongolia do không có dữ liệu từ năm 2013-2016. (Phương pháp hồi quy ngưỡng trên Fixed Effect đòi hỏi dữ liệu phải là dạng bảng cân bằng - balanced panel). Vì thế các phân tích dựa trên số liệu thị trường chứng khoán chỉ còn 22 quốc gia trong giai đoạn 2004-2016.

Dữ liệu được thu thập từ các tổ chức quốc tế uy tín là bộ dữ liệu World Development Indicators (WDI), Global Financial Development Database (GFDD), và World Governance Indicators (WGI) của World Bank, Thống kê của Quỹ tiền tệ quốc tế IMF, Chương trình Phát triển Liên Hiệp Quốc (UNDP).

Bảng 3.1 trình bày 33 quốc gia trong mẫu nghiên cứu còn được chia thành hai sub-sample (mẫu phụ) dựa trên Tiêu chuẩn phân nhóm quốc gia theo GNI bình quân đầu người của World Bank gần đây nhất là năm 2017, được tính từ đơn vị nội tệ chuyển đổi sang đô-la Mỹ. Các nước trên thế giới được chia thành 4 nhóm như sau:

Nhóm thu nhập thấp:

Nhóm thu nhập trung bình thấp: GNI bình quân đầu người từ $996 \$-3895 \$$

Nhóm thu nhập trung bình cao: GNI bình quân đầu người từ 3896 - $12055 \$$

Nhóm thu nhập cao:
GNI bình quân đầu người $\leq 995 \$$

GNI bình quân đầu người $\geq 12056 \$$

Đối chiếu với tiêu chuẩn trên thì trong mẫu nghiên cứu của luận án này không có nước nào thuộc nhóm thu nhập thấp.

Các nước trong mẫu được phân chia ra hai mẫu phụ: Nhóm 1(ký hiệu: Nhóm High income) gồm có 20 nước, là các nước có thu nhập cao và trung bình cao, tức là có GNI bình quân đầu người từ $3896 \$$ trở lên. Nhóm 2 (ký hiệu: Nhóm Middle 
income) gồm có 13 nước, là các nước có thu nhập trung bình thấp, tức là GNI bình quân đầu người từ $996 \$-3895 \$$.

Bảng 3.1 Phân loại các nước trong mẫu theo thu nhập

\begin{tabular}{|lll|ll|}
\hline \multicolumn{2}{|c|}{ Nhóm 1: High income (20 nước) } & \multicolumn{2}{c|}{ Nhóm 2: Middle income (13 nước) } \\
\hline Bahrain & Kazakhstan & Armenia* & India & Nepa** \\
China & Saudia Arab & Brunei* & Indonesia & Bangladesh* \\
Iran & Malaysia & Kuwait* & Pakistan & Cambodia* \\
Israel & Singapore & Maldives* & Phillipines & Kyrgyz Republic* \\
Japan & South Korea & Turkey & Sri Lanka & Mongolia* \\
Jordan & Qatar & UAE & Vietnam & Myanmar* \\
Russia & Thailand & & & Taijikistan* \\
\hline
\end{tabular}

Nguồn: Tiêu chuẩn phân nhóm quốc gia theo GNI bình quân đầu người (World Bank)

Việc phân chia ra hai mẫu phụ có hai mục đích: thứ nhất là bổ sung vào khoảng trống của các nghiên cứu trước đây, thứ hai là kiểm nghiệm các kết luận tìm thấy trong toàn mẫu đã được đề cập ở phần trên có khác biệt gì không khi bối cảnh các nước nghiên cứu khác biệt nhau về thu nhập. Nếu các kết quả là nhất quán trong toàn mẫu cũng như trong các mẫu phụ thì kết luận tìm thấy được gia tăng tính vững và độ tin cậy.

\subsection{Mô hình nghiên cứu}

Như đã phân tích ở chương 2 , lý thuyết tăng trưởng nội sinh cho rằng phát triển tài chính thông qua quá trình mở rộng, gia tăng về quy mô và chất lượng của trung gian tài chính và các sản phẩm tài chính đã tạo điều kiện để có thể huy động tiết kiệm, phân bổ nguồn lực để đầu tư hiệu quả nhất; cùng với đó là giảm thông tin giao dịch; chi phí giám sát; đa dạng hóa rủi ro; cuối cùng là tạo ra những điều kiện thuận lợi cho việc trao đổi hàng hóa dịch vụ; tích tụ nhanh chóng hơn cả về nguồn vốn vật chất lẫn con người. Vì vậy, phát triển tài chính là một biến số quan trọng 
trong mô hình tăng trưởng kinh tế, phản ánh những thay đổi trong mức sản lượng quốc gia.

Do đó, trên nền tảng lý thuyết tăng trưởng nội sinh, kế thừa và phát triển mô hình nghiên cứu theo King và Levine (1993 a,b) luận án thực hiện phân tích mối quan hệ trong dài hạn giữa phát triển tài chính và tăng trưởng kinh tế theo mô hình sau đây:

$$
G R O W T H_{i t}=\beta F D_{i t}+\gamma X_{i t}+\varepsilon_{i t} \quad \text { (phương trình 3.1) }
$$

Trong đó GROWTH $H_{i t}$ đại diện cho tỷ lệ tăng trưởng kinh tế

FD it đại diện cho mức độ phát triển tài chính của quốc gia, đo lường bằng năm chỉ tiêu dựa trên dữ liệu ngân hàng và dữ liệu thị trường chứng khoán.

X là tập hợp các biến kiểm soát, là các nhân tố ảnh hưởng khác đến tăng trưởng kinh tế mà lý thuyết đã đề cập bao gồm: biến income đại diện cho nhân tố thu nhập, biến invest thể hiện nhân tố đầu tư, nhân tố lao động được thể hiện qua biến pop là chỉ tiêu tốc độ tăng dân số, nguồn vốn con người (human capital) được thể hiện bằng biến mys đo lường số năm đi học trung bình của người dân. Biến income $e_{i t-1}$ được đưa vào mô hình để phân tích bởi vì các nước thu nhập thấp (đang phát triển) có xu hướng có tốc độ tăng trưởng trung bình cao hơn so với các nước thu nhập cao nhưng tác động này có độ trễ, tức là thu nhập bình quân đầu người năm trước tác động đến tốc độ tăng GDP năm nay.

$\varepsilon_{i t}$ là phần sai số trong mô hình. i $=1, \ldots, \mathrm{N}$ là chỉ số thể hiện quốc gia. $\mathrm{t}=$ $1, \ldots, \mathrm{T}$ là chỉ số đại diện cho thời gian (năm).

Để có thể nắm bắt được tác động thay đổi của phát triển tài chính khi vượt qua ngưỡng, theo Law và Singh (2014) phương trình (3.1) cần được mở rộng thêm với hàm chỉ mục $\mathrm{I}($.) sẽ nhận giá trị = 1 nếu biểu thức trong ngoặc là đúng, và nhận giá trị $=0$ trong trường hợp ngược lại. Do đó phương trình (3.1) được phát triển thành phương trình (3.2) sau đây:

$$
\begin{array}{r}
\text { GROWTH } H_{i t}=\mu_{i}+\beta_{1} F D_{i t} I\left(F D_{i t} \leq \lambda\right)+\delta_{1} I\left(F D_{i t} \leq \lambda\right)+\beta_{2} F D_{i t} I\left(F D_{i t}>\lambda\right)+ \\
\gamma X_{i t}+\theta_{t+} \varepsilon_{i t}
\end{array}
$$


Trong đó:

$\mathrm{i}=1, \ldots, \mathrm{N}$ là chỉ số thể hiện quốc gia.

$\mathrm{t}=1, \ldots, \mathrm{T}$ là chỉ số đại diện cho thời gian.

$\mu_{\mathrm{i}}$ là hiệu ứng cố định theo từng quốc gia. $\theta_{t}$ là hiệu ứng thời gian. Mức độ phát triển tài chính được thể hiện qua biến FD là biến có ngưỡng (threshold variable) được dùng trong mô hình với vai trò là biến giải thích vừa dùng để phân chia các quan sát thành hai miền tác động.

$\lambda$ là tham số của ngưỡng, và giá trị này không biết trước.

I(.) là hàm chỉ mục, sẽ nhận giá trị = 1 nếu biểu thức trong ngoặc là đúng, và nhận giá trị $=0$ trong trường hợp ngược lại. Nhờ vậy các quan sát sẽ đưa chia vào hai miền tác động tùy thuộc giá trị của biến FD lớn hơn hay nhỏ hơn giá trị tham số ngưỡng $\lambda$.

Một cách diễn đạt khác của hàm chỉ mục này là:

$$
\begin{aligned}
& \text { GROWTH } H_{i t}=\mu_{i}+\delta_{1}+\beta_{1} F D_{i t}+\gamma X_{i t}+\theta_{t+} \varepsilon_{i t} \quad \text { khi } F D_{i t} \leq \lambda \\
& \text { GROWTH }_{i t}=\mu_{i}+\beta_{2} F D_{i t}+\gamma X_{i t}+\theta_{t+} \varepsilon_{i t} \quad \text { khi } F D_{i t}>\lambda
\end{aligned}
$$

Hàm chỉ mục này sẽ chia tác động của biến giải thích lên biến phụ thuộc thành 2 miền tác động (regime) khác nhau, chúng phân biệt với nhau bởi hệ số tương quan khác nhau là $\beta_{1}$ và $\beta_{2}$. $\delta_{1}$ là hệ số chặn, giống nhau với tất cả các quốc gia. Mô hình hồi quy ngưỡng này giúp nắm bắt tác động của phát triển tài chính (biến FD) lên tăng trưởng (biến GROWTH) thay đổi ra sao khi giá trị của biến FD thấp hơn hoặc cao hơn tham số ngưỡng $\lambda$ chưa biết trước.

$\mathrm{X}_{\mathrm{it}}$ là vector $\mathrm{m}$ chiều của các biến kiểm soát.

Để xác định kết quả của mô hình nghiên cứu, luận án sử dụng phương pháp ước lượng hồi quy ngưỡng cho dữ liệu bảng được đề xuất ban đầu bởi Hansen (1999) và sau đó được Wang (2015) phát triển trên phần mềm Stata là Mô hình Hồi quy ngưỡng với Fixed Effect (Fixed Effect Panel Threshold Model). 
Để củng cố cho tính vững của kết quả ước lượng, luận án thực hiện lần lượt thêm các biến giải thích khác vào mô hình hồi quy, bao gồm biến tradeop đại diện cho độ mở thương mại, biến infla đại diện cho yếu tố lạm phát trong nền kinh tế, biến inst phản ánh đánh giá về nhân tố thể chế.

Theo Thai-Ha Le và cộng sự (2016), chất lượng thể chế chính trị tốt hơn sẽ thúc đẩy sự phát triển của khu vực tài chính và qua đó thúc đẩy tăng trưởng kinh tế tại các nền kinh tế đang phát triển châu Á. Các nhà nghiên cứu này cũng kết luận rằng độ mở thương mại là yếu tố quan trọng tác động đến tăng trưởng kinh tế của các nền kinh tế phát triển cao.

Chi tiêu chính phủ cũng là nhân tố tác động đến tăng trưởng kinh tế, ảnh hưởng đến giá trị GDP của một quốc gia, đồng thời phản ánh được qui mô, phạm vi của hàng hóa công cộng do chính phủ cung cấp cũng như cho thấy tác động bóp méo của chi tiêu công và thuế. Nhiều nghiên cứu lý thuyết lẫn thực nghiệm đã phân tích vai trò của chi tiêu chính phủ đến nền kinh tế. Do đó, biến goexp đại diện cho chi tiêu chính cũng được thêm vào mô hình nghiên cứu làm biến kiểm soát.

Các biện pháp khác nhằm kiểm tra tính vững của kết quả tìm được cũng được thực hiện trong luận án này bao gồm thay thế cách đo lường biến số, phân chia mẫu nghiên cứu thành hai mẫu phụ để kiểm định lại kết quả, dùng phương pháp ước lượng system - GMM theo Arellano và Bond (1991) với biến giả và biến tương tác như là một phương pháp phân tích thay thế cho phương pháp ước lượng hồi quy ngưỡng.

\subsection{Các biến số trong mô hình}

\subsubsection{Biến phụ thuộc (Tăng trưởng kinh tế - GROWTH)}

Biến phụ thuộc trong nghiên cứu này là Tăng trưởng kinh tế (ký hiệu biến: GROWTH $_{\mathrm{it}}$ ). Tăng trưởng kinh tế được định nghĩa là sự gia tăng về năng lực sản xuất cũng như cung ứng hàng hóa - dịch vụ của nền kinh tế trong một khoảng thời gian nhất định. Trên thế giới, có rất nhiều thước đo được sử dụng để đo lường biến số kinh tế này chẳng hạn như tốc độ tăng GDP thực, tốc độ tăng GDP danh nghĩa, tốc độ tăng GNP...v.v. 
Ở đây, tốc độ tăng trưởng GDP thực hằng năm được lựa chọn làm đại diện cho sự tăng trưởng kinh tế (theo Samargandi và cộng sự, 2015) . Việc lựa chọn này mang lại nhiều ưu điểm. Trước hết, theo định nghĩa, GDP chính là giá trị tính bằng tiền của tất cả sản phẩm và dịch vụ cuối cùng được sản xuất ra trong phạm vi một lãnh thổ trong một khoảng thời gian nhất định, vì thế dựa vào GDP của một quốc gia có thể đánh giá được phần nào năng lực hiện tại của nền kinh tế. Hơn nữa, sử dụng tốc độ tăng GDP thực giúp loại bỏ những tác động của lạm phát hay sự thay đổi của chỉ số giá, nhờ đó thể hiện một cách tốt hơn cũng như chân thực hơn những sự thay đổi xảy ra trong nền kinh tế. Law và Singh (2014) trong nghiên cứu của mình chọn khung thời gian là 5 năm để tính giá trị trung bình cho các biến. Do đặc trưng của mẫu trong nghiên cứu này ít kỳ quan sát, hơn nữa là chuỗi dữ liệu trong nghiên cứu này ít có tính chu kỳ. Vì vậy, trong luận án này, tác giả luận án sử dụng dữ liệu theo tần suất năm mà không tính trung bình 5 năm để làm trơn dữ liệu như các tác giả đi trước.

Theo khung lý thuyết về các mô hình tăng trưởng kinh tế, tăng trưởng chịu tác động của các nhân tố: lao động (dân số), vốn vật chất, kiến thức và vốn con người, tự do hóa thương mại, thể chế, thu nhập, và các nhân tố khác như đầu tư, tích lũy vốn, lạm phát, trình độ công nghệ, ...

\subsubsection{Biến độc lập (Phát triển tài chính - FD)}

Biến độc lập chính trong nghiên cứu này là Phát triển tài chính được đo lường bằng nhiều chỉ số để phản ánh sự phát triển đa diện của hệ thống tài chính. Ký hiệu là $\mathrm{FD}_{\mathrm{it}-1}$

Theo các tài liệu nghiên cứu trong thời gian gần đây, Phát triển tài chính cần đạt đến một mức tối ưu mà vượt qua mức này thì nó lại cản trở tăng trưởng kinh tế, nghĩa là sẽ tồn tại một điểm chuyển tiếp mà tác động của Phát triển tài chính sẽ đổi chiều. Vì vậy đây là biến tạo ra giá trị tham số ngưỡng, và cũng là biến có sự thay đổi tác động lên biến phụ thuộc GROWTH trong mô hình hồi quy.

Lần lượt các phương trình hồi quy ngưỡng được thực hiện với các cách đo lường khác nhau cho biến FD. Kết quả nghiên cứu đạt được nhất quán dù đo lường 
FD bằng chỉ số nào sẽ là bằng chứng về tính vững của kết luận. Các chỉ số đo lường FD được thực hiện trong nghiên cứu này bao gồm:

$\checkmark$ Tỷ số tín dụng cho khu vực tư nhân trên GDP, ký hiệu là privatecre

$\checkmark$ Tỷ số Nợ thanh khoản trên GDP, ký hiệu là liq

$\checkmark$ Tỷ số tín dụng trong nước trên GDP, ký hiệu là domescre

Ba chỉ tiêu nói trên là cách đo lường Phát triển tài chính dựa trên mức độ phát triển của khu vực ngân hàng (bank-based), là thành phần dẫn dắt chủ đạo trong hệ thống tài chính các nước châu Á đang phát triển.

Ngoài ra, để phản ánh đa diện sự phát triển của hệ thống tài chính theo xu hướng tương lai, các phương trình hồi quy được ước lượng với cách đo lường Phát triển tài chính dựa trên mức độ phát triển của thị trường tài chính, thông qua các chỉ số về thị trường chứng khoán bao gồm:

$\checkmark$ Tỷ số Quy mô vốn hóa thị trường chứng khoán trên GDP, để phản ánh độ sâu của thị trường tài chính, ký hiệu là sm_capliz.

$\checkmark$ Tỷ số sinh lợi của thị trường chứng khoán, để phản ánh tính hiệu quả của thị trường tài chính, ký hiệu là sm_turnover.

$\checkmark$ Tỷ số Quy mô giao dịch của TTCK trên GDP, cũng thể hiện độ sâu của thị trường tài chính, ký hiệu là sm_trade

\subsubsection{Các biến kiểm soát}

Việc xem xét các biến kiểm soát sau đây đại diện cho các nhân tố tác động đến tăng trưởng kinh tế là dựa trên lý thuyết tăng trưởng nội sinh. Cụ thể như sau:

- Dân số: Đây là nhân tố hình thành lao động trong nền kinh tế cũng như nguồn vốn về tri thức và con người. Nhân tố này được phản ánh bằng Tỷ lệ gia tăng dân số hàng năm của các quốc gia, ký hiệu là pop (Law và Singh, 2014). Chỉ số này thể hiện mức thay đổi dân số của một quốc gia và có thể được xem là đại diện cho nguồn vốn con người ở quốc gia đó. Đối với những quốc gia đang phát triển trong 
đó có Việt Nam, khi mà trình độ phát triển khoa học - công nghệ còn chưa cao thì số lượng cũng như chất lượng của lực lượng lao động sẽ đóng vai trò quyết định đến năng lực sản xuất của nền kinh tế. Nhiều nghiên cứu đi trước cho thấy rằng quy mô, tốc độ gia tăng dân số và tăng trưởng kinh tế có mối quan hệ chặt chẽ với nhau. Tuy nhiên mối quan hệ giữa hai biến số này còn tùy thuộc vào đặc điểm của các quốc gia đang xem xét cũng như sự thay đổi của từng yếu tố. Ở các nước đang phát triển, quy mô dân số lớn, tăng nhanh với chi phí giáo dục, phúc lợi xã hội, y tế thì quá trình tăng dân số sẽ ảnh hưởng tiêu cực đến tăng trưởng kinh tế. Ngoài ra, Mankiw và cộng sự (1992) còn cho rằng tốc độ tăng dân số cao hơn tăng trưởng kinh tế còn khiến cho vốn có sẵn phải dàn trải mỏng hơn, ảnh hưởng tiêu cực lên tăng trưởng. Tuy nhiên, ở một khía cạnh khác, không thể phủ nhận rằng, tăng dân số là điều kiện tạo ra một nguồn lao động trẻ, dồi dào, ham học hỏi, thích ứng nhanh với những thay đổi, điều này lại góp một phần không hề nhỏ trong việc thúc đẩy tăng trưởng. Cùng với đó, dân số tăng lên kéo theo nhu cầu vật phẩm tiêu dùng và dịch vụ tăng lên kích thích sản xuất phát triển kinh tế. Do đó, kì vọng dấu của mối quan hệ giữa dân số và tăng trưởng kinh tế là $(+/-)$.

- Thu nhập: được thể hiện qua chỉ tiêu GDP bình quân đầu người, ký hiệu là income. Thu nhập được các lý thuyết tăng trưởng đánh giá là một nhân tố ảnh hưởng quan trọng lên mối quan hệ giữa tăng trưởng kinh tế và phát triển tài chính, thể hiện mức độ phát triển của nền kinh tế. Ở những quốc gia có thu nhập trung bình và thu nhập cao, sự phát triển tài chính không chỉ giúp tích lũy vốn mà còn tăng cường sự tăng trưởng năng suất nhờ vậy mà thúc đẩy nền kinh tế tăng trưởng (Rioja và Valev, 2004b). Beck, Degryse, và Kneer (2014) cũng đồng quan điểm về mối tương quan dương này với Rioja và Valev. Nhưng Law và Singh (2014) lại tìm thấy mối tương quan này là âm. Trong trung hạn, số liệu thực tế cho thấy các nước đang phát triển và thị trường mới nổi thì tốc độ tăng trưởng kinh tế nhanh hơn so với các nước đã phát triển, nghĩa là thu nhập bình quân đầu người càng cao thì tốc độ tăng trưởng kinh tế chậm lại (Weicheng Lian và cộng sự, 2019). Do 
đó để xem xét tác động của nhân tố này, ngoài biến incomeit thì cũng xem xét biến

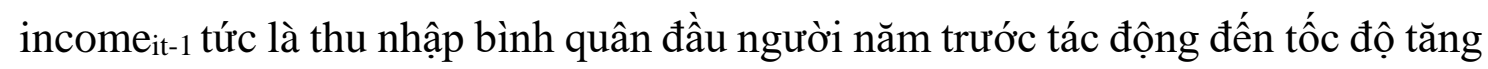
GDP năm nay. Vấn đề đa cộng tuyến giữa biến income it và biến trễ 1 chu kỳ của nó incomeit-1 nếu có cũng không gây hại cho mô hình bởi vì kết quả hồi quy, các biến vẫn đạt ý nghĩa thống kê. Ngoài ra, biến thu nhập cũng chỉ là biến kiểm soát, không phải là biến chính. Kỳ vọng về dấu của hệ số tương quan là (+/-)

- Đầu tư: được thể hiện qua chỉ tiêu Tỷ số đầu tư vốn gộp trên GDP (Gross capital formation \% of GDP), hay còn có tên gọi là Tỷ lệ đầu tu nội địa gộp, ký hiệu là invest. Chỉ số này cho biết sự đầu tư vào nhà ở cũng như đầu tư vào các yếu tố khác như đường xá, dinh thự, cầu cống, đường sắt, mạng lưới điện, trang bị máy móc...v.v. từ đó có thể xác định tiềm năng tăng trưởng tương lai của nền kinh tế. Đây được xem như là một nhân tố đóng vai trò quan trọng trong các mô hình tăng trưởng, đặc biệt với những quốc gia đang phát triển như Việt Nam. Do đó, dấu của mối quan hệ cũng được kỳ vọng là (+).

- Tự do hóa thương mại: được thể hiện qua chỉ số Độ mở thương mại \% so với $G D P$, ký hiệu là tradeop. Chỉ số này cho biết tổng lượng hàng hóa và dịch vụ thông qua xuất nhập khẩu chiếm bao nhiêu phần trong tổng sản phẩm quốc nội. Nhắc lại công thức tính GDP: tổng sản phẩm quốc nội = tiêu dùng + đầu tư + chi tiêu của chính phủ + xuất khẩu - nhập khẩu, như vậy, có thể thấy rằng giá trị xuất khẩu và nhập khẩu có ảnh hưởng rất lớn đến sự thay đổi của GDP hay nói cách khác chính là tác động lên tăng trưởng kinh tế. Ngoài ra, giá trị hàng hóa xuất nhập khẩu còn đại diện cho sự mở cửa - tự do hóa thương mại, một nhân tố có ảnh hưởng đến tăng trưởng kinh tế của các quốc gia nhất là trong giai đoạn toàn cầu hóa một cách mạnh mẽ như hiện nay. Tương tự, biến tradeop được kì vọng thể hiện tương quan dương với tăng trưởng kinh tế.

- Lạm phát: được phản ánh bằng chi số lạm phát tính theo CPI với năm gốc là năm 2010, ký hiệu là infla. Lạm phát được kì vọng gây tác động tiêu cực, dấu (-) lên tăng trưởng vì nó là dấu hiệu cho những bất ổn trong nền kinh tế. Giá cả gia 
tăng vì lạm phát sẽ ảnh hưởng tiêu cực đến sản lượng của các ngành nghề và khu vực kinh tế.

- Thể chế: phản ánh thể chế chính trị quốc gia. Trong bộ chỉ số World Governance Indicators, tổ chức quốc tế World Bank đã đánh giá về thể chế của từng quốc gia trên sáu phương diện là: Mức độ kiểm soát tham nhũng, Mức độ hiệu quả của chính quyền, Sự ổn định chính trị và không có tình trạng bạo lực hay khủng bố, Chất luợng của các chính sách ban hành bởi chính quyền, Luật pháp, Quyền tự do ngôn luận và trách nhiệm giải trình. Mức điểm số đánh giá của cả sáu chỉ tiêu này đều được chuẩn hóa theo phân phối chuẩn, các giá trị phân bổ trong vùng (2,5; 2,5) Biến phản ánh môi trường thể chế chính trị trong nghiên cứu này được ký hiệu là inst, là giá trị trung bình mức điểm của sáu chỉ tiêu nói trên. Acemoglu và Robinson (2008) cho rằng sự khác biệt về thể chế là nguyên nhân dẫn đến khác biệt về tăng trưởng kinh tế giữa các quốc gia. Thể chế tốt sẽ giúp định hình chính sách và luật lệ tốt hơn, hỗ trợ cho các hoạt động kinh tế, giúp phân bổ nguồn lực trong nền kinh tế hiệu quả hơn. Do đó, biến inst được kỳ vọng có tương quan (+) với biến phụ thuộc.

- Chi tiêu của chính phủ: được đo lường bằng tỷ lẹ \% chi tiêu của chính phủ so với $G D P$, ký hiệu là goexp. Chỉ số này đo lường tổng mức chi tiêu cuối cùng của chính phủ bao gồm tất cả các khoản chi thường xuyên của chính phủ để mua bán hàng hóa - dịch vụ, chi tiền lương cho cán bộ - công chức, cũng như chi tiêu cho quốc phòng - an ninh quốc gia. Các nghiên cứu trước đây về vai trò của chi tiêu chính phủ đến nền kinh tế có thể được phân chia thành hai nhóm chính: nhóm thứ nhất lập luận rằng tăng chi tiêu chính phủ cùng với gia tăng hàng hóa công sẽ tạo thêm công ăn việc làm, tăng sức mua của người dân, ổn định xã hội, thông qua đó tác động tích cực lên tăng trưởng kinh tế (Kelly, 1997; Alexious, 2007; Gitana và cộng sự, 2018). Nhóm thư hai thì cho rằng tăng chi tiêu chính phủ sẽ làm chậm sự tăng trưởng kinh tế (Knoop, 1999; Wahab, 2004; Mitchell, 2005). Do đó, tương quan của biến số này với biến phụ thuộc có thể là (+) hoặc (-). 
- Nguồn vốn con người: trong nghiên cứu này, nguồn vốn con người được đo lường bằng hai cách:

- Số năm đi học trung bình, ký hiệu là mys

- Chỉ số phát triển con người (Human Development Index) được công bố bởi UNDP (Chương trình Phát triển Liên Hiệp Quốc), ký hiệu là hci

Các mô hình lý thuyết và tài liệu nghiên cứu trước đã chỉ ra tầm quan trọng của nguồn vốn con người trong thúc đẩy tăng trưởng kinh tế dài hạn. Một vấn đề đặt ra ở đây là đo lường vốn nhân lực, hay còn gọi là vốn con người, như thế nào. Đây thật sự là một vấn đề phức tạp và khó đo lường bởi vì vốn con người là một khái niệm rộng đề cập đến năng lực của một cá nhân, cả về thể chất lẫn tinh thần. Kiến thức và kỹ năng của con người được tích lũy trong suốt cuộc đời, là quá trình học tập từ trường lớp chính thức đến không chính thức. Có ba phương pháp mà những nhà kinh tế thường sử dụng để đo lường nguồn vốn nhân lực trong các nghiên cứu đó là:

(1) Số năm đi học trung bình. Đây là phương pháp phổ biến để đo lường nguồn vốn con người trong nhiều nghiên cứu trước đây như Barro và Lee (1993), Benhabid và Spiegel (1994), Krueger và Lindahl (2001), Cohen và Soto (2007), Portela và cộng sự (2004). Ủu điểm của phương pháp này là số liệu có thể tiếp cận đầy đủ, có thể phân tích và so sánh giữa các quốc gia. Nhược điểm là chưa thể đại diện đầy đủ cho toàn bộ ý nghĩa về khái niệm nguồn vốn nhân lực.

(2) Thực hiện những cuộc kiểm tra trực tiếp để biết được năng lực, kỹ năng, và kiến thức có liên quan đến hoạt động kinh tế của một cá nhân tại một thời điểm nào đó. Ví dụ Hanushek và Kimko (2000) dùng điểm thi quốc tế về khoa học, toán, đọc hiểu của sinh viên tại 43 quốc gia để làm thước đo và xác nhận rằng vốn nhân lực có vai trò tích cực đối với tăng trưởng. Tuy nhiên sự phức tạp ở đây là khó xác định phải đo lường yếu tố nào bởi vì vốn nhân lực bao gồm nhiều khía cạnh, có những thuộc tính mà ta không thể đo lường thành giá trị gộp, ví dụ như thái độ, động cơ. 
(3) Đo lường một cách gián tiếp thông qua thu nhập của người lao động. Phương pháp này dựa trên giả định rằng thu nhập mà cá nhân có được là một biến số thể hiện giá trị thị trường của vốn nhân lực. Một người có thu nhập cao được suy diễn là do họ có vốn nhân lực cao. Với phương pháp này, các nhà nghiên cứu lượng hóa vốn nhân lực bằng tiền với lập luận là năng suất lao động cao dẫn đến thu nhập cao, mà năng suất khác nhau là do giáo dục hoặc kỹ năng khác nhau. Trong thực tế, mối quan hệ này không phải lúc nào cũng đúng.

Mặc dù còn nhiều tranh cãi về các phương pháp đo lường nói trên, luận án chọn thực hiện đo lường biến nguồn vốn con người bằng chỉ tiêu "Số năm đi học trung bình" để khai thác ưu điểm của phương pháp này là nguồn dữ liệu đầy đủ và có thể phân tích và so sánh giữa các quốc gia trong mẫu. Các nhà nghiên cứu kỳ vọng số năm đi học đại diện cho chất lượng giáo dục. Số năm đi học càng cao thì vốn con người tăng lên, về mặt lý thuyết sẽ tạo ra tăng trưởng kinh tế cao hơn, kì vọng dấu (+) cho mối tương quan.

Ngoài ra còn thực hiện đo lường bằng Chỉ số phát triển con người (Human Development Index) được công bố bởi UNDP (Chương trình Phát triển Liên Hiệp Quốc). Số năm đi học trung bình là trung bình số năm hoàn tất việc đi học thực tế của những người từ 25 tuổi trở lên với cách tính toán là chuyển đổi trình độ học vấn đạt được, sử dụng khoảng thời gian chính thức đến trường của mỗi cấp độ đào tạo. Dữ liệu này của UNDP được thu thập từ thống kê chính thức của UNESCO và tính toán theo phương pháp của Barro và Lee (2013). Bảng 3.2 trình bày tóm tắt về các biến số trong mô hình nghiên cứu. 
Bảng 3.2 Tóm tắt các biến số trong mô hình nghiên cứu

\begin{tabular}{|c|c|c|c|c|c|}
\hline & Nhân tố & Ký hiệu biến & Nội dung & Đơn vị & Nguồn \\
\hline $\begin{array}{l}\text { Biến } \\
\text { phụ } \\
\text { thộc }\end{array}$ & $\begin{array}{l}\text { Tăng } \\
\text { trưởng } \\
\text { kinh tế }\end{array}$ & GROWTH & $\begin{array}{l}\text { tốc độ tăng trưởng GDP thực } \\
\text { hằng năm }\end{array}$ & $\%$ & WDI \\
\hline \multirow{6}{*}{$\begin{array}{l}\text { Biến } \\
\text { độc } \\
\text { lập }\end{array}$} & \multirow{6}{*}{$\begin{array}{l}\text { Phát } \\
\text { triển } \\
\text { tài } \\
\text { chính }\end{array}$} & privatecre & $\begin{array}{l}\text { Tỷ số tín dụng cho khu vực tư } \\
\text { nhân trên GDP }\end{array}$ & $\%$ & WDI \\
\hline & & domescre & $\begin{array}{l}\text { Tỷ số tín dụng trong nước } \\
\text { trên GDP }\end{array}$ & $\%$ & WDI \\
\hline & & liq & Nợ thanh khoản trên GDP & $\%$ & GFDD \\
\hline & & sm_capliz & $\begin{array}{l}\text { Tỷ số Quy mô vốn hóa của } \\
\text { TTCK trên GDP }\end{array}$ & $\%$ & GFDD \\
\hline & & sm_turnover & $\begin{array}{l}\text { Tỷ số sinh lợi của thị trường } \\
\text { chứng khoán }\end{array}$ & $\%$ & GFDD \\
\hline & & sm_trade & $\begin{array}{l}\text { Tỷ số Quy mô giao dịch của } \\
\text { TTCK trên GDP }\end{array}$ & $\%$ & GFDD \\
\hline \multirow{8}{*}{$\begin{array}{l}\text { Biến } \\
\text { kiểm } \\
\text { soát }\end{array}$} & Dân số & pop & $\begin{array}{l}\text { Tỷ lệ gia tăng dân số hàng } \\
\text { năm }\end{array}$ & $\%$ & WDI \\
\hline & $\begin{array}{l}\text { Thu } \\
\text { nhập }\end{array}$ & income & GDP bình quân đầu người & & WDI \\
\hline & Đầu tư & invest & $\begin{array}{l}\text { Tỷ số đầu tư vốn gộp trên } \\
\text { GDP }\end{array}$ & $\%$ & WDI \\
\hline & $\begin{array}{l}\text { Thương } \\
\text { mại }\end{array}$ & tradeop & $\begin{array}{l}\text { Độ mở thương mại \% so với } \\
\text { GDP }\end{array}$ & $\%$ & WDI \\
\hline & $\begin{array}{l}\text { Lạm } \\
\text { phát }\end{array}$ & infla & chỉ số lạm phát tính theo CPI & $\%$ & WDI \\
\hline & Thể chế & inst & $\begin{array}{l}\text { Điểm số trung bình trên } 6 \\
\text { phương diện }\end{array}$ & & WGI \\
\hline & \multirow{2}{*}{$\begin{array}{l}\text { Vốn con } \\
\text { người }\end{array}$} & mys & Số năm đi học trung bình & năm & UNDP \\
\hline & & hci & Chỉ số phát triển con người & & UNDP \\
\hline
\end{tabular}

\subsection{Phương pháp ước lượng}

Phần này trình bày khuôn khổ chung cho việc phân tích dữ liệu bảng, thảo luận và so sánh những phương pháp thường được sử dụng để phân tích loại dữ liệu này.

Các tài liệu nghiên cứu trước ở chương 2 cho thấy các nghiên cứu thực nghiệm về mối quan hệ này đã được các nhà nghiên cứu tiến hành bằng nhiều phương pháp 
ước lượng đa dạng. Trong thời kỳ đầu, khi kinh tế lượng còn chưa phát triển như ngày nay, phương pháp chủ đạo mà các nghiên cứu sử dụng chỉ đơn giản là hồi quy OLS trên dữ liệu chéo. Những nghiên cứu trong giai đoạn này sử dụng dữ liệu chéo theo quốc gia với phương pháp hồi quy bình phương nhỏ nhất (OLS) đã thừa nhận rằng có mối quan hệ dương giữa phát triển tài chính và tăng trưởng kinh tế. Tuy nhiên, phương pháp hồi quy OLS là cách ước lượng tốt nhất chỉ khi nào các giả định của nó được thỏa mãn. Các nghiên cứu thời kỳ này chưa đảm bảo được việc thỏa năm giả định của phương pháp OLS. Hơn nữa, dù sau này có những nghiên cứu đã cải tiến phương pháp ước lượng như Ergungor (2008) nghiên cứu cho 46 nước phát triển và đang phát triển với phương pháp mới hơn là 2 SLS nhưng vẫn sử dụng dữ liệu chéo bằng cách lấy trung bình từ năm 1980-1995. Những kết luận dựa trên việc phân tích dữ liệu chéo (cross-sectional data) thì nhạy cảm đối với mẫu các quốc gia được chọn: sẽ là không thích hợp khi kết luận chung cho tất cả các quốc gia khác nhau như một thể đồng nhất (Khan và Senhadji, 2003; Chuah và Thai, 2004). Việc chỉ sử dụng dữ liệu chéo đã không khai thác được ý nghĩa của sự biến động theo thời gian của dữ liệu. Vấn đề về quan hệ nhân quả không được giải quyết một cách cụ thể trong một số nghiên cứu dữ liệu chéo (Khan và Senhadji, 2003). Bên cạnh đó, việc sử dụng biến công cụ là không thể giải quyết được vấn đề nội sinh khi dữ liệu được được tính trung bình qua thời gian dài (Ericsson và cộng sự, 2001). Những hạn chế nói trên của việc dùng dữ liệu chéo và phương pháp ước lượng hồi quy đơn giản làm cho các kết luận tìm thấy có thể bị hoài nghi.

Về sau, khi kinh tế lượng ngày càng phát triển và chủ đề phát triển tài chính thu hút sự quan tâm của nhiều học giả thì nhiều bằng chứng thực nghiệm với phương pháp ước lượng khác nhau được thực hiện, sử dụng dữ liệu chuỗi thời gian. Đơn cử như Arestis và Demetriades (1997) áp dụng phân tích nghiệm đơn vị và phương pháp ước lượng VAR cho hai nước là Đức và Mỹ; Puatwoe và Piabuo (2017) với phương pháp ARDL nghiên cứu cho một quốc gia là Cameroon. Những phương pháp này đều là những phương pháp ước lượng có ưu điểm trong kỹ thuật phân tích nhưng đòi hỏi chuỗi dữ liệu phải đủ lớn, có độ dài thời gian đủ nhiều thì kết quả phân tích mới có ý 
nghĩa. Đây cũng là lý do mà các tác giả trên cũng chỉ giới hạn phân tích cho một số quốc gia vì tính phức tạp của mô hình. Để khắc phục những hạn chế do sử dụng dữ liệu chéo và dữ liệu chuỗi thời gian, dữ liệu bảng là dạng dữ liệu được đề xuất trong các nghiên cứu sau này như Rioja và Valev (2004a) nghiên cứu trên dữ liệu bảng và sử dụng phương pháp GMM; Loayza và Ranciere (2006) dùng mô hình Errorcorrection model (ECM) cho dũ̃ liệu bảng để ước lượng theo phương pháp Pooled Mean Group (gộp trung bình nhóm). Phương pháp Pooled Mean Group được đề xuất bởi Perasan và Smith (1995) là một phương pháp tốt cho kết quả ước lượng các tham số có giá trị trung bình nhất quán và không cần xét đến tính đồng nhất có thể có giữa các nhóm. Tuy nhiên phương pháp này đòi hỏi một cỡ mẫu lớn nên không phù hợp với đối tượng và mẫu nghiên cứu của luận án này.

\subsubsection{Phương pháp hồi quy ngưỡng dành cho dữ liệu bảng}

Xuất phát từ mục tiêu của nghiên cứu này là kiểm định tác động của phát triển tài chính lên tăng trưởng kinh tế tại nhiều quốc gia châu Á, cần phải phân tích trên dữ liệu của nhiều quốc gia và trong một khoảng thời gian nhiều năm mới nắm bắt được chính xác các tác động thật sự trong mối quan hệ giữa hai nhân tố nói trên. Vì vậy, dữ liệu bảng và mô hình hồi quy ngưỡng trên dữ liệu bảng (Panel Threshold Regression) của Hansen (1999) được lựa chọn sử dụng trong luận án này để phục vụ cho phân tích. Ủu điểm của phương pháp này là đơn giản nhưng xác định cụ thể giá trị của ngưỡng trong mối quan hệ phi tuyến.

Trong các tài liệu nghiên cứu trước đây, một số tác giả thể hiện quan hệ phi tuyến bằng phương trình hồi quy bậc hai như Cecchetti và Kharouroubi (2012), hay Samargandi và cộng sự (2015). Tuy nhiên cần làm rõ là: mối quan hệ phi tuyến không nhất thiết phải có dạng thức của hàm bậc hai $\mathrm{X}^{2}$. Tuyến tính là một thuật ngữ xuất phát từ tiếng La-tinh, có nghĩa là "có liên quan hoặc tương tự một đường thẳng”, thông thường được dùng để mô tả mối quan hệ giữa hai đại lượng có thể biểu diễn trên đồ thị là một đường thẳng. Thuật ngữ "phi tuyến" được dùng với ý nghĩa là đồ thị biểu diễn mối quan hệ giữa hai đại lượng không phải là đường thẳng, mà có xuất 
hiện điểm chuyển tiếp (hay còn gọi là giá trị ngưỡng - threshold) và tác động giữa các biến số có sự thay đổi đáng kể. Sự thay đổi ở đây có thể hiểu là đổi chiều tác động, hoặc không thay đổi chiều tác động nhưng có thay đổi mức độ tác động.

Mô hình ngưỡng (threshold model) được sử dụng trong các nghiên cứu thuộc nhiều lĩnh vực khác nhau. Ý tưởng tổng quát của mô hình ngưỡng đó là một quá trình mà tác động của biến độc lập lên biến phụ thuộc sẽ khi các giá trị của biến độc lập vượt quá một ngưỡng nhất định, nói cách khác tác động của biến số này lên biến phụ thuộc sẽ khác nhau trong trường hợp các giá trị lớn hơn ngưỡng so với khi chúng ở dưới ngưỡng.

Ngày nay mô hình ngưỡng được sử dụng rộng rãi trong các phân tích tài chính và phân tích vĩ mô bởi vì sự đơn giản và rõ ràng trong hàm ý chính sách. Tuy nhiên, với những mô hình này thì việc ước lượng và suy diễn là khá phức tạp bởi sự tồn tại của các tham số nhiễu. Để khắc phục vấn đề này, Hansen (1999) đề xuất một mô hình ngưỡng với ước lượng tác động cố định. Thực chất, kỹ thuật hồi quy ngưỡng này đã từng được Hansen giới thiệu lần đầu năm 1996 nhưng lúc đó ông sử dụng dữ liệu chéo (cross-sectional data). Nhược điểm của dữ liệu chéo là không phản ánh được sự khác biệt của các chủ thể nghiên cứu theo thời gian nên làm giảm hiệu lực của kết luận nghiên cứu. Mô hình Panel Threshold Regression do Hansen (1999) đề xuất dùng cho dữ liệu bảng đã cải tiến hơn so với dữ liệu chéo, có thể phân tách các quan sát đơn lẻ trong mẫu thành các miền tác động dựa trên giá trị của một biến quan sát được, ước lượng giá trị ngưỡng bằng phương pháp bình phương nhỏ nhất (Least squares estimation) và các hệ số góc của hàm hồi quy được tính toán theo phép biến đổi tác động cố định (Fixed Effect).

Lý thuyết suy luận tiệm cận không chuẩn tắc được Hansen phát triển cho phép xây dựng khoảng tin cậy và kiểm định các giả thuyết. Phát triển dựa trên ý tưởng nền tảng của Hansen (1999), Wang (2015) giới thiệu trên phần mềm Stata mô hình hồi quy ngưỡng Fixed Effect trên dữ liệu bảng cân bằng. Với những ưu điểm trội hơn của dữ liệu bảng so với dữ liệu chéo và dữ liệu chuỗi thời gian, ngày nay phương pháp 
ước lượng hồi quy ngưỡng này được sử dụng rộng rãi trong các phân tích kinh tế vĩ mô và tài chính bởi tính đơn giản trong ứng dụng và ý nghĩa kinh tế mà nó đem lại. Phương pháp hồi quy ngưỡng từng được một số nhà nghiên cứu sử dụng trong phân tích của họ như Rosseau và Wachtel (2002), Girma (2005).

Mô hình hồi quy ngưỡng trên dữ liệu bảng được trình bày như sau:

Dữ liệu quan sát là dạng bảng cân bằng với tập hợp giá trị của ba biến số $\mathrm{y}_{\mathrm{it}}$, $\mathrm{q}_{\mathrm{it}}, \mathrm{x}_{\mathrm{it}}$ với $1 \leq \mathrm{i} \leq \mathrm{n} \quad 1 \leq \mathrm{t} \leq \mathrm{T}$

i là chỉ số đại diện cho từng cá thể trong mẫu và $t$ là chỉ mục thời gian. Biến phụ thuộc là $y_{i t}$ và biến có ngưỡng là $q_{i t}$. $x_{i t}$ là vector $k$ chiều các hệ số hồi quy. Phương trình hồi quy có cấu trúc thay đổi được trình bày như sau:

$$
y_{i t}=\mu_{i}+\beta_{1}^{\prime} x_{i t} I\left(q_{i t} \leqslant \gamma\right)+\beta_{2}^{\prime} x_{i t} I\left(q_{i t}>\gamma\right)+e_{i t} .
$$

Trong đó I(.) là hàm chỉ mục. Một cách trình bày dạng khác của phương trình (1) là:

$$
y_{i t}= \begin{cases}\mu_{i}+\beta_{1}^{\prime} x_{i t}+e_{i t}, & q_{i t} \leqslant \gamma \\ \mu_{i}+\beta_{2}^{\prime} x_{i t}+e_{i t}, & q_{i t}>\gamma\end{cases}
$$

Với vector $\mathrm{x}_{\mathrm{it}}$ là:

$$
\begin{aligned}
& x_{i t}(\gamma)=\left(\begin{array}{l}
x_{i t} I\left(q_{i t} \leqslant \gamma\right) \\
x_{i t} I\left(q_{i t}>\gamma\right)
\end{array}\right) \\
& \beta=\left(\begin{array}{ll}
\beta_{1}^{\prime} & \beta_{2}^{\prime}
\end{array}\right)^{\prime}
\end{aligned}
$$

Vì vậy phương trình (1) tương đương với:

$$
y_{i t}=\mu_{i}+\beta^{\prime} x_{i t}(\gamma)+e_{i t} .
$$

Các quan sát được chia vào hai miền tác động (regime) phụ thuộc vào giá trị của biến qit lớn hơn hay nhỏ hơn giá trị của ngưỡng $\gamma$. Hai regime này phân biệt với nhau bởi hệ số góc $\beta_{1} \beta_{2}$ khác nhau. Sai số e $i$ được giả định có phân phối độc lập và đồng nhất 
với giá trị trung bình bằng 0 và phương sai xác định. Giả định này hàm ý loại bỏ các biến phụ thuộc có độ trễ ra khỏi tập hợp xit.

Phương pháp ước lương Least squares: cách thức loại trừ tác động riêng lẻ là phương pháp khử trung bình theo đối tượng (individual - specific means):

Phương trình (1) trình bày theo từng chỉ số thời gian $\mathrm{t}$ sẽ tạo ra hàm hồi quy thành phần là:

$$
\bar{y}_{i}=\mu_{i}+\beta^{\prime} \bar{x}_{i}(\gamma)+\bar{e}_{i}
$$

Trong đó:

$$
\begin{aligned}
\bar{y}_{i}=T^{-1} \sum_{t=1}^{T} y_{i t}, \bar{e}_{i}=T^{-1} \sum_{t=1}^{T} e_{i t}, \\
\bar{x}_{i}(\gamma)=\frac{1}{T} \sum_{t=1}^{T} x_{i t}(\gamma) \\
=\left(\begin{array}{l}
\frac{1}{T} \sum_{t=1}^{T} x_{i t} I\left(q_{i t} \leqslant \gamma\right) \\
\frac{1}{T} \sum_{t=1}^{T} x_{i t} I\left(q_{i t}>\gamma\right)
\end{array}\right) .
\end{aligned}
$$

Lấy phương trình (2) trừ cho phương trình (3) ta có:

$$
y_{i t}^{*}=\beta^{\prime} x_{i t}^{*}(\gamma)+e_{i t}^{*}
$$

Trong đó:

$$
\begin{gathered}
y_{i t}^{*}=y_{i t}-\bar{y}_{i}, \\
x_{i t}^{*}(\gamma)=x_{i t}(\gamma)-\bar{x}_{i}(\gamma), \\
e_{i t}^{*}=e_{i t}-\bar{e}_{i} .
\end{gathered}
$$

Xét: 


$$
y_{i}^{*}=\left[\begin{array}{c}
y_{i 2}^{*} \\
\vdots \\
y_{i T}^{*}
\end{array}\right], \quad x_{i}^{*}(\gamma)=\left[\begin{array}{c}
x_{i 2}^{*}(\gamma)^{\prime} \\
\vdots \\
x_{i T}^{*}(\gamma)^{\prime}
\end{array}\right], \quad e_{i}^{*}=\left[\begin{array}{c}
e_{i 2}^{*} \\
\vdots \\
e_{i T}^{*}
\end{array}\right]
$$

Phương trình (4) được viết lại là:

$$
Y^{*}=X^{*}(\gamma) \beta+e^{*}
$$

Với bất kỳ giá trị $\gamma$ cho trước, hệ số góc $\beta$ có thể ước lượng được bằng OLS, tức là:

$$
\hat{\beta}(\gamma)=\left(X^{*}(\gamma)^{\prime} X^{*}(\gamma)\right)^{-1} X^{*}(\gamma)^{\prime} Y^{*} .
$$

Vector phần dư của hồi quy là:

$$
\hat{e}^{*}(\gamma)=Y^{*}-X^{*}(\gamma) \hat{\beta}(\gamma)
$$

Tổng bình phương sai số là:

$$
\begin{aligned}
& S_{1}(\gamma)=\hat{e}^{*}(\gamma)^{\prime} \hat{e}^{*}(\gamma) \\
& =Y^{*}\left(I-X^{*}(\gamma)^{\prime}\left(X^{*}(\gamma)^{\prime} X^{*}(\gamma)\right)^{-1} X^{*}(\gamma)^{\prime}\right) Y^{*} .
\end{aligned}
$$

Chan (1993) và Hansen (1999) đề xuất ước lượng giá trị ngưỡng bằng phương pháp Least squares là cách dễ dàng nhất để đạt tổng bình phương sai số là bé nhất:

$$
\hat{\gamma}=\underset{\gamma}{\operatorname{argmin}} S_{1}(\gamma) \text {. }
$$

Khi đã tính được $\gamma$ thì hệ số góc:

$$
\hat{\beta}=\hat{\beta}(\hat{\gamma}) .
$$

Vector phần dư là:

$$
\hat{e}^{*}=\hat{e}^{*}(\hat{\gamma})
$$

Phương sai của phần dư là: 


$$
\hat{\sigma}^{2}=\frac{1}{n(T-1)} \hat{e}^{*^{\prime}} \hat{e}^{*}=\frac{1}{n(T-1)} S_{1}(\hat{\gamma})
$$

Hansen (1999) đề xuất dùng phương pháp ước lượng bootstrap để kiểm định giả thuyết Ho là không tồn tại ngưỡng. Nếu p-value $<\alpha$ thì Ho bị bác bỏ, chứng tỏ giá trị ngưỡng có tồn tại, mối quan hệ là phi tuyến.

\subsubsection{Phương pháp hồi quy GMM}

Bên cạnh đó, sau khi xác định được giá trị của ngưỡng của biến FD, biến giả thred sử dụng để phân chia các quan sát thành hai regime: các quan sát trên điểm ngưỡng và các quan sát dưới điểm ngưỡng. Biến tương tác giữa biến giả thred và biến $F D$ - ký hiệu là biến $\mathrm{tt}$ - được bổ sung vào phương trình và thực hiện ước lượng hồi quy bằng phương pháp system - GMM theo Arellano và Bond (1991) trên dữ liệu bảng động để phân tích tác động của phát triển tài chính lên tăng trưởng kinh tế trước và sau điểm chuyển tiếp. Vì vậy, phương trình sẽ được viết lại dưới dạng sau đây:

GROWTH $H_{i t}=\beta_{0}+\beta_{1} F D_{i t}+\beta_{2} t t_{i t}+\beta_{k} X k_{i t}+\theta_{t+} \varepsilon_{i t} \quad$ (phương trình 3.3)

Hệ số hồi quy $\beta_{1}$ của biến FD thể hiện tác động của phát triển tài chính đến tăng trưởng kinh tế trong miền giá trị trước ngưỡng của FD.

Hệ số hồi quy $\beta_{2}$ của biến tương tác là chênh lệch hệ số góc của biến FD sau ngưỡng và trước ngưỡng. Do đó, tác động của phát triển tài chính đến tăng trưởng kinh tế trong miền giá trị sau ngưỡng của $\mathrm{FD}$ (ký hiệu là $\left.\beta^{*}\right)$ bằng $\left(\beta_{1}+\beta_{2}\right)$

$\mathrm{Xk}_{\mathrm{it}}$ là vector các biến kiểm soát gồm biến pop, income, invest, tradeoop, infla, goexp, inst, và biến thể hiện về nguồn vốn con người (biến mys, hoặc biến hci).

Việc áp dụng phương pháp system - GMM để ước lượng phương trình (3.3) góp phần giải quyết các vấn đề có thể phát sinh trong hồi quy dữ liệu bảng như vấn đề nội sinh, phương sai thay đổi, và tự tương quan.

Ưu điểm của mô hình GMM trên dữ liệu bảng so với mô hình ước lượng biến công cụ đó là mô hình GMM dễ dàng chọn các biến công cụ hơn, có thể sử dụng biến 
trễ của biến bị nội sinh làm biến công cụ; cũng thể hiện hàm ý tương lai không tác động ngược lại quá khứ. Hơn nữa, ước lượng GMM được giới thiệu bởi Arellano và Bond (1991) phù hợp với các dữ liệu bảng có số lượng quốc gia $\mathrm{N}$ trong mẫu quan sát lớn hơn so với với chuỗi thời gian $\mathrm{T}$ ghi nhận. Ngoài ra, việc sử dụng phương pháp system - GMM như là một phương pháp phân tích thay thế để trả lời cho cùng một vấn đề nghiên cứu cũng là một trong các cách thức để xem xét kết quả nghiên cứu đạt được của luận án có nhất quán và vững hay không. Ước lượng system - GMM có hiệu quả hơn trong các trường hợp mẫu nhỏ

Arellano và Bond (1991) đã đề nghị hai kiểm định chủ chốt để kiểm tra tính hiệu lực của mô hình GMM. Kiểm định đầu tiên đó là kiểm định Sargan hoặc kiểm định Hansen cho tính hiệu lực (Overidentification) của mô hình. Kiểm định thứ hai được sử dụng đó là kiểm định Arellano-Bond nhằm kiểm định cho sự tự tương quan. Lệnh xtabond2 được giới thiệu bởi Roodman (2009) được sử dụng trong Stata15 để thực hiện ước lượng system-GMM.

Khi ước lượng bằng system - GMM, luận án cũng thực hiện kiểm định giả thuyết Ho: không có tác động của biến FD lên biến phu thuộc, khi FD vuợt qua giá trị nguỡng. Tức là kiểm định giả thuyết Ho: $\beta^{*}=0$

Một cách viết khác của giả thuyết Ho là:

$$
\text { Ho: }\left(\beta_{1}+\beta_{2}=0\right)
$$

Giả thuyết Ho này bị bác bỏ khi p-value $<\alpha$, thì sự tồn tại của giá trị ngưỡng được xác nhận, hay nói cách khác là xác nhận có mối quan hệ phi tuyến giữa phát triển tài chính và tăng trưởng kinh tế. 


\section{Kết luận chương 3}

Chương này trình bày về việc các câu hỏi nghiên cứu và giả thuyết nghiên cứu được giải quyết như thế nào thông qua việc phân tích số liệu thứ cấp trên mẫu nghiên cứu về 33 quốc gia châu Á trong giai đoạn 2004-2016. Phương pháp nghiên cứu mà luận án sử dụng để phân tích mối quan hệ phi tuyến giữa phát triển tài chính và tăng trưởng kinh tế là hồi quy ngưỡng với Fixed Effect cho dữ liệu bảng được đề xuất bởi Hansen (1999) và được giới thiệu trên Stata bởi Wang (2015).

Bên cạnh đó, để củng cố cho các kết luận tìm thấy, biến giả và biến tương tác được sử dụng trong phương trình hồi quy ước lượng bằng phương pháp system-GMM theo Arellano và Bond (1991) và được giới thiệu bởi Roodman (2009) như là một phương pháp phân tích thay thế, đồng thời xử lý nguy cơ về vấn đề nội sinh trong các bộ dữ liệu về tài chính có thể xảy ra.

Ngoài cách dùng phương pháp ước lượng thay thế khác, các kiểm định khác cho tính vững của kết quả được thực hiện thông qua việc thay thế cách đo lường biến số, phân tích trên mẫu phụ (sub-sample).

Trong chương kế tiếp, các kết quả thực nghiệm ghi nhận được bằng các phương pháp nói trên sẽ được phân tích và thảo luận, từ đó đề xuất các hàm ý về mặt chính sách phát triển cho tài chính quốc gia. 


\section{CHƯONG 4 KÊTT QUẢ NGHIÊN CÚU}

\subsection{Thống kê mô tả}

Mẫu nghiên cứu gồm 33 nền kinh tế châu Á trong giai đoạn từ 2004-2016 tạo thành dữ liệu bảng cân bằng (balanced panel) với các thống kê được ghi nhận như sau:

Bảng 4.1 Thống kê mô tả toàn mẫu

\begin{tabular}{|l|c|r|r|r|r|}
\hline Biến & Số quan sát & Trung bình & Độ lệch chuẩn & GT nhỏ nhất & \multicolumn{1}{|c|}{ GT lớn nhất } \\
\hline growth & 429 & 5,377195 & 4,277762 & $-14,15$ & 26,1702 \\
\hline pop & 429 & 2,033399 & 2,440679 & $-0,8638$ & 16,3316 \\
\hline income & 429 & 14055,7 & 17567,18 & 491,6975 & 72670,96 \\
\hline invest & 429 & 27,51565 & 7,944809 & 10,3775 & 58,1507 \\
\hline tradeop & 429 & 94,68592 & 66,81454 & 0,1674 & 441,6038 \\
\hline infla & 429 & 5,938118 & 5,431072 & $-4,8633$ & 39,2664 \\
\hline goexp & 429 & 13,68105 & 5,038939 & 3,4603 & 30,0035 \\
\hline inst & 429 & $-0,2190224$ & 0,6902128 & $-1,7516$ & 1,5922 \\
\hline mys & 429 & 8,415385 & 2,579076 & 2,7 & 12,8 \\
\hline hci & 429 & 2,55965 & 0,597483 & & 3,71 \\
\hline privatecre & 429 & 58,65262 & 39,22993 & 3,1211 & 173,537 \\
\hline domescre & 429 & 71,82900 & 59,13059 & $-10,1518$ & 345,7219 \\
\hline liquid & 429 & 65,41786 & 42,66564 & 6,7058 & 217,702 \\
\hline
\end{tabular}

Nguồn: Tác giả tính toán

Kết quả thống kê cho thấy các nền kinh tế châu Á trong mẫu nghiên cứu có tốc độ tăng trưởng kinh tế trung bình khoảng 5,37\% với giá trị cao nhất ghi nhận lên đến 26,17\%. So với khu vực các nước đã phát triển châu Âu và châu Mỹ thì tốc độ tăng trưởng này là khá cao vì trong mẫu có nhiều nền kinh tế mới nổi như Trung Quốc, Nhật Bản, Ân Độ, Indonesia, Hàn Quốc, Thổ Nhĩ Kỳ, Iran, Saudi Arab, Russia, Singapore, Thái Lan có tốc độ tăng trưởng nhanh vượt bậc trong thời kỳ hiện đại. Tuy 
nhiên trong giai đoạn nghiên cứu cũng có năm 2008 khủng hoảng tài chính xảy ra trên toàn cầu, vì thế không tránh khỏi một số thị trường không giữ vững được tốc độ tăng trưởng cao như trước, thậm chí còn giảm đến mức -14,15\% (Armenia năm 2009). Thu nhập bình quân đầu người của các nền kinh tế trong mẫu nghiên cứu là 14 055,7 USD/năm.

Các quốc gia châu Á trong mẫu đa số là các nền kinh tế mới nổi nên có độ mở thương mại cao, chiếm trung bình 94,69\% GDP. Mức độ tự do hóa thương mại cao này đem lại cơ hội và thúc đẩy tăng trưởng cho nền kinh tế, tuy nhiên khi có các cú sốc bất thường về kinh tế vĩ mô trên thế giới thì các nền kinh tế châu Á này cũng là đối tượng hấp thu các tác động tiêu cực của các cú sốc khá lớn.

Bảng 4.2 Thống kê các chỉ tiêu Phát triển tài chính toàn mẫu

\begin{tabular}{|l|c|r|r|r|r|}
\hline \multicolumn{1}{|c|}{ Biến } & $\begin{array}{c}\text { Số quan } \\
\text { sát }\end{array}$ & Trung bình & \multicolumn{1}{c|}{$\begin{array}{c}\text { Độ lệch } \\
\text { chuẩn }\end{array}$} & GT nhỏ nhất & GT lớn nhất \\
\hline privatecre & 429 & 58,65262 & 39,22993 & 3,1211 & 173,537 \\
\hline domescre & 429 & 71,82900 & 59,13059 & $-10,1518$ & 345,7219 \\
\hline liquid & 429 & 65,41786 & 42,66564 & 6,7058 & 217,702 \\
\hline sm_capliz & 286 & 68,11876 & 51,33095 & 0,4086 & 260,408 \\
\hline sm_turnover & 286 & 67,09454 & 72,28417 & 0,839 & 556,912 \\
\hline sm_traded & 286 & 44,07054 & 50,39478 & 0,079 & 331,271 \\
\hline
\end{tabular}

Nguồn: Tác giả tính toán

Về các chỉ tiêu phản ánh sự phát triển của hệ thống tài chính cho thấy các quốc gia trong mẫu đang trong giai đoạn thúc đẩy sự phát triển tài chính. Tỷ số tín dụng cung ứng cho khu vực tư nhân chiếm trung bình 58,65\% so với GDP, tín dụng trong nước chiếm trung bình là 71,83\% GDP, nợ thanh khoản hay cung tiền mở rộng M3 chiếm trung bình là 65,42\% GDP. Đặc biệt, trong mẫu có quốc gia Ả Rập Saudi (Saudi Arabia) năm 2008, 2010-2013 có giá trị tín dụng trong nước nhỏ hơn 0.

Trong mẫu nghiên cứu này, có 5 quốc gia hoàn toàn chưa có thị trường chứng khoán, đó là Brunei, Cambodia, Maldives, Myanmar, và Taijikistan. Brunei mặc dù 
được xếp vào nhóm nước thu nhập cao trên thế giới và tăng trưởng chủ yếu nhờ thu nhập từ tài nguyên là dầu mỏ, nhưng vẫn chưa phát triển thị trường chứng khoán. Maldives là đảo quốc, là quốc gia nhỏ nhất châu Á về dân số và tập trung phát triển về du lịch. Ba nước còn lại thuộc nhóm nước nghèo và chậm phát triển. Sáu quốc gia khác là Armenia, Bangladesh, Kuwait, Kyrgyz Republic, Nepal, Mongolia không có dữ liệu từ năm 2013-2016. Vì vậy dữ liệu về TTCK chỉ còn 286 quan sát.

Về sự phát triển của thị trường tài chính, thể hiện qua các chỉ tiêu đo lường thị trường chứng khoán, các nước trong mẫu có quy mô vốn hóa trung bình chiếm 68,12\% so với GDP; tỷ suất sinh lợi của TTCK trung bình là 67,09\%; quy mô tổng giá trị giao dịch của TTCK trung bình là 44,07\% so với GDP.

Trong mẫu có nhiều nước thể hiện tăng trưởng nóng đối với TTCK nên giá trị cao nhất trong mẫu gấp đôi so với GDP $(260,4 \%)$ như Jordan quy mô vốn hóa cao liên tục từ 2004 -2011 với quy mô năm 2007 lên đến 230,83\%; Malaysia từ 20042016 quy mô vốn hóa luôn trên 100\% so với GDP (từ 115,3\% đến 148,54\%).

Phần lớn các nước trong mẫu có giá trị vốn hóa thị trường trong giai đoạn 2007-2008 đều trên 100\% so với GDP như Bahrain năm 2006-2007 là 112,52\%; Indonesia 2007 là 113,33\%, Qatar năm 2007 là 112,67\%, ..

Singapore, Nhật, Hàn Quốc, Thái Lan là những quốc gia có TTCK phát triển mạnh liên tục, từ 2004-2016 quy mô vốn hóa của các thị trường này thường cao hơn trên mức trung bình của mẫu, trên $80 \%$ so với GDP. Đặc biệt Singapore từ năm 20042016 luôn có mức quy mô vốn hóa TTCK từ 163,05\% - 260,4\% là quốc gia đạt giá trị cao nhất về quy mô vốn hóa TTCK. Việt Nam có TTCK mới phát triển nên quy mô còn nhỏ bé với mức trung bình chỉ có 16,1\% cho cả giai đoạn 2004-2016 nhưng năm 2007 cũng tăng trưởng nóng ở mức 18,04\%.

Bảng 4.3 trình bày Ma trận tương quan giữa các biến số, cho thấy không có hiện tượng đa cộng tuyến nghiêm trọng giữa các biến trong mô hình. 
Bảng 4.3 Ma trận tương quan giữa các biến trong mô hình nghiên cứu

\begin{tabular}{|c|c|c|c|c|c|c|c|c|c|c|c|c|}
\hline & growth & privatecre & domescre & liq & pop & income & invest & tradeop & infla & goexp & inst & mys \\
\hline growth & 1 & & & & & & & & & & & \\
\hline privatecre & $-0,1977$ & 1 & & & & & & & & & & \\
\hline domescre & $-0,1929$ & 0,8997 & 1 & & & & & & & & & \\
\hline liq & $-0,1717$ & 0,8753 & 0,8752 & 1 & & & & & & & & \\
\hline pop & 0,1952 & $-0,1072$ & $-0,1291$ & $-0,0687$ & 1 & & & & & & & \\
\hline income & $-0,0660$ & 0,3321 & 0,3188 & 0,3203 & 0,5399 & 1 & & & & & & \\
\hline invest & 0,2217 & 0,1479 & 0,0740 & 0,1295 & $-0,0143$ & $-0,1092$ & 1 & & & & & \\
\hline tradeop & 0,0148 & 0,2710 & 0,0367 & 0,2127 & 0,2001 & 0,3083 & $-0,0991$ & 1 & & & & \\
\hline infla & 0,1334 & $-0,3725$ & $-0,3385$ & $-0,3892$ & $-0,0180$ & $-0,3210$ & 0,2001 & $-0,2113$ & 1 & & & \\
\hline goexp & $-0,2627$ & 0,1492 & 0,1571 & 0,1990 & 0,0139 & 0,3007 & $-0,1447$ & $-0,0491$ & $-0,2837$ & 1 & & \\
\hline inst & $-0,1601$ & 0,6066 & 0,5429 & 0,5485 & 0,2329 & 0,7652 & $-0,0450$ & 0,4993 & $-0,4946$ & 0,2816 & 1 & \\
\hline mys & $-0,1805$ & 0,2892 & 0,2388 & 0,1891 & $-0,0111$ & 0,3561 & 0,0154 & 0,1817 & $-0,1932$ & 0,3535 & 0,4971 & 1 \\
\hline
\end{tabular}




\subsection{Phân tích tác động phi tuyến của phát triển tài chính đến tăng trưởng kinh tế trên dữ liệu về ngân hàng}

Tiếp theo, để thực hiện mục tiêu nghiên cứu, luận án sẽ lần lượt phân tích trên phương diện các chỉ tiêu đo lường dựa trên mức độ phát triển của khu vực ngân hàng, sau đó sẽ tiếp tục mở rộng sang các chỉ tiêu phản ánh sự phát triển của thị trường tài chính. Bối cảnh các nền kinh tế đang phát triển châu Á đang tồn tại thực trạng là nhiều quốc gia chưa hình thành thị trường chứng khoán, các nền kinh tế châu Á chủ yếu tăng trưởng cùng với sự phát triển của hệ thống ngân hàng. Vì vậy, sự phát triển của hệ thống ngân hàng giữ vai trò tác động lớn trong hệ thống tài chính, nên các phân tích trong luận án này sẽ tập trung đánh giá trên các chỉ tiêu đo lường của khu vực ngân hàng.

\subsubsection{Kết quả hồi quy ngưỡng}

\subsubsection{Tín dụng cho khu vục tư nhân}

Chỉ số đo lường thứ nhất đại diện cho Phát triển tài chính là tỷ lệ Tín dụng cho khu vực tư nhân so với GDP được thực hiện hồi quy ngưỡng Fixed Effect với kết quả được trình bày trong bảng 4.4. Mô hình (1a) là kết quả hồi quy giữa biến phụ thuộc Growth, biến FD, và các biến kiểm soát gồm: pop, income, invest, mys.

Mô hình (2a), (3a), (4a), (5a) là lần lượt bổ sung thêm biến kiểm soát tradeop, infla, goexp, inst. Mô hình (6a) là thay cách đo lường biến nguồn vốn con người thông qua số năm đi học trung bình (biến mys) bằng chỉ số phát triển con người (biến hci).

Kiểm định sự tồn tại của ngưỡng được thực hiện, kết quả được trình bày trong bảng 4.5 
Bảng 4.4 Kết quả hồi quy ngưỡng với FD đo lường bằng Tín dụng cho khu vực tư nhân/GDP

\begin{tabular}{|c|c|c|c|c|c|c|}
\hline & Mô hình 1a & Mô hình 2a & Mô hình 3a & Mô hình 4a & Mô hình 5a & Mô hình 6a \\
\hline $\begin{array}{l}\text { Giá trị } \\
\text { ngưỡng } \\
\text { (KTC 95\%) }\end{array}$ & $\begin{array}{l}\mathbf{8 , 9 7 6 2} \\
(8,4427 \\
9,3103)\end{array}$ & $\begin{array}{r}\mathbf{8 , 9 7 6 2} \\
(8,4427 \\
9,3103)\end{array}$ & $\begin{array}{l}\quad \mathbf{8 , 9 7 6 2} \\
(8,4427 \\
9,3103)\end{array}$ & $\begin{array}{r}\mathbf{8 , 9 7 6 2} \\
(8,4427 ; \\
9,3103)\end{array}$ & $\begin{array}{r}\mathbf{8 , 9 7 6 2} \\
(8,4427 \\
9,3103)\end{array}$ & $\begin{array}{r}\mathbf{8 , 9 7 6 2} \\
(8,4427 \\
9,3103)\end{array}$ \\
\hline Trước ngưỡng & $\begin{array}{r}\mathbf{0 , 6 0 0} * * * \\
(0,000)\end{array}$ & $\begin{array}{r}\mathbf{0 , 6 6 1} * * * \\
(0,000)\end{array}$ & $\begin{array}{r}\mathbf{0 , 6 5 9} * * * \\
(0,000)\end{array}$ & $\begin{array}{r}\mathbf{0 , 6 1 8}^{* * * *} \\
(0,000)\end{array}$ & $\begin{array}{r}\mathbf{0 , 5 9 4} * * * \\
(0,000)\end{array}$ & $\begin{array}{r}\mathbf{0 , 5 9 8} * * * \\
(0,000)\end{array}$ \\
\hline Sau ngưỡng & $\begin{array}{r}-\mathbf{0 , 0 2 9 6} * * \\
(0,039)\end{array}$ & $\begin{array}{l}-\mathbf{0 , 0 2 9 2} * * \\
(-0,040)\end{array}$ & $\begin{array}{r}-\mathbf{0 , 0 2 8 2} * * \\
(0,049)\end{array}$ & $\begin{array}{r}-\mathbf{0 , 0 2 1 5} \\
(0,139)\end{array}$ & $\begin{array}{r}\mathbf{- 0 , 0 2 0 9} \\
(0,152)\end{array}$ & $\begin{array}{r}-\mathbf{0 , 0 2 2 5} \\
(0,102)\end{array}$ \\
\hline pop & $\begin{array}{r}\mathbf{0 , 9 5 4} * * * \\
(0,000)\end{array}$ & $\begin{array}{r}\mathbf{0 , 9 7 8} * * * \\
(0,000)\end{array}$ & $\begin{array}{r}\mathbf{0 , 9 6 6 * * * *} \\
(0,000)\end{array}$ & $\begin{array}{r}\mathbf{0 , 9 0 0 * * * *} \\
(0,000)\end{array}$ & $\begin{array}{r}\mathbf{0 , 8 9 4} * * * \\
(0,000)\end{array}$ & $\begin{array}{r}\mathbf{0 , 9 0 4} * * * \\
(0,000)\end{array}$ \\
\hline income & $\begin{array}{r}\mathbf{0 , 0 0 2 7 4} * * * \\
(0,000)\end{array}$ & $\begin{array}{r}\mathbf{0 , 0 0 2 7 5} * * * \\
(0,000)\end{array}$ & $\begin{array}{r}\mathbf{0 , 0 0 2 7 5} * * * \\
(0,000)\end{array}$ & $\begin{array}{r}\mathbf{0 , 0 0 2 6 7} * * * \\
0,000\end{array}$ & $\begin{array}{r}\mathbf{0 , 0 0 2 6 9} * * * \\
0,000\end{array}$ & $\begin{array}{r}\mathbf{0 , 0 0 2 6 8} * * * \\
0,000\end{array}$ \\
\hline invest & $\begin{array}{r}\mathbf{0 , 1 2 7} * * * \\
(0,000)\end{array}$ & $\begin{array}{r}\mathbf{0 , 1 2 8} * * * \\
(0,000)\end{array}$ & $\begin{array}{r}\mathbf{0 , 1 2 6} * * * * \\
(0,000)\end{array}$ & $\begin{array}{r}\mathbf{0 , 1 3 1} * * * \\
(0,000)\end{array}$ & $\begin{array}{r}\mathbf{0 , 1 3 7 * * * *} \\
(0,000)\end{array}$ & $\begin{array}{r}\mathbf{0 , 1 3 6} * * * * \\
(0,000)\end{array}$ \\
\hline mys & $\begin{array}{r}\mathbf{- 0 , 2 5 3} \\
(0,440)\end{array}$ & $\begin{array}{r}\mathbf{- 0 , 1 6} \\
(0,623)\end{array}$ & $\begin{array}{r}\mathbf{- 0 , 1 5} \\
(0,647)\end{array}$ & $\begin{array}{r}-\mathbf{0 , 0 0 7 3} \\
(0,983)\end{array}$ & $\begin{array}{r}\mathbf{- 0 , 0 3 7 7} \\
(0,911)\end{array}$ & \\
\hline L.income & $\begin{array}{r}-\mathbf{0 , 0 0 2 7} * * * * \\
(0,000)\end{array}$ & $\begin{array}{r}-\mathbf{0 , 0 0 2 7} * * * \\
(0,000)\end{array}$ & $\begin{array}{r}-\mathbf{0 , 0 0 2 7} * * * \\
(0,000)\end{array}$ & $\begin{array}{r}-\mathbf{0 , 0 0 2 6} \mathbf{6}^{* * * *} \\
(0,000)\end{array}$ & $\begin{array}{r}-\mathbf{0 , 0 0 2 6} \mathbf{6}^{* * * *} \\
(0,000)\end{array}$ & $\begin{array}{r}-\mathbf{0 , 0 0 2 6} \mathbf{6}^{* * * *} \\
(0,000)\end{array}$ \\
\hline tradeop & & $\begin{array}{r}\mathbf{0 , 0 2 7 7 * *} \\
(0,012)\end{array}$ & $\begin{array}{r}\mathbf{0 , 0 2 6 0} * * \\
(0,021)\end{array}$ & $\begin{array}{r}\mathbf{0 , 0 2 5 8}^{* *} \\
(0,021)\end{array}$ & $\begin{array}{r}\mathbf{0 , 0 2 6 5 * *} \\
(0,019)\end{array}$ & $\begin{array}{r}\mathbf{0 , 0 2 7 1} * * \\
(0,016)\end{array}$ \\
\hline infla & & & $\begin{array}{l}\mathbf{0 , 0 2 6 9} \\
(0,436)\end{array}$ & $\begin{array}{l}\mathbf{0 , 0 1 8 5} \\
(0,593)\end{array}$ & $\begin{array}{l}\mathbf{0 , 0 1 1 3} \\
(0,756)\end{array}$ & $\begin{array}{l}\mathbf{0 , 0 1 0 7} \\
(0,766)\end{array}$ \\
\hline goexp & & & & $\begin{array}{r}-\mathbf{0 , 1 9 7} * * \\
(0,039)\end{array}$ & $\begin{array}{r}\mathbf{- 0 , 1 9 7 * * *} \\
(0,039)\end{array}$ & $\begin{array}{r}-\mathbf{0 , 2 1 4} * * \\
(0,025)\end{array}$ \\
\hline inst & & & & & $\begin{array}{r}\mathbf{- 1 , 0 1 6} \\
(0,486)\end{array}$ & $\begin{array}{r}\mathbf{- 0 , 8 3 4} \\
(0,568)\end{array}$ \\
\hline hci & & & & & & $\begin{array}{r}\mathbf{0 , 5 2 8} \\
(0,437)\end{array}$ \\
\hline _cons & $\begin{array}{r}2,74 \\
(0,292)\end{array}$ & $\begin{array}{l}-1,585 \\
(0,609)\end{array}$ & $\begin{array}{l}-1,571 \\
(0,612)\end{array}$ & $\begin{array}{r}0,151 \\
(0,962)\end{array}$ & $\begin{array}{l}-0,222 \\
(0,945)\end{array}$ & $\begin{array}{r}-1,372 \\
(0,63)\end{array}$ \\
\hline $\mathrm{N}$ & 396 & 396 & 396 & 396 & 396 & 396 \\
\hline Adj-R ${ }^{2}$ & 0,434 & 0,442 & 0,442 & 0,447 & 0,446 & 0,447 \\
\hline
\end{tabular}

$* \mathrm{p}<0,1, * * \mathrm{p}<0,05, * * * \mathrm{p}<0,01$ 


\section{Bảng 4.5 Kiểm định sự tồn tại của ngưỡng khi FD = Tín dụng cho khu vụ̣c tư nhân/GDP}

\begin{tabular}{|c|c|c|c|c|c|c|c|}
\hline \multicolumn{8}{|c|}{ Threshold estimator $($ level $=95)$} \\
\hline Threshold & Lower & Upper & & & & & \\
\hline 8,9762 & 8,4427 & 9,3103 & & & & & \\
\hline \multicolumn{8}{|c|}{ Threshold effect test $($ bootstrap $=50)$ : } \\
\hline Threshold & RSS & MSE & Fstat & Prob & Crit10 & Crit5 & Crit1 \\
\hline Single & 2654,88 & 6,9137 & 18,53 & 0,04 & 13,6324 & 14,4721 & 25,2301 \\
\hline
\end{tabular}

Nguồn: Tác giả tính toán

Kiểm định về sự tồn tại của ngưỡng (Threshold effect test) với giả thuyết:

$$
\begin{aligned}
& H_{0}: \beta_{1}=\beta_{2} \text { (No threshold effect) } \\
& H_{1}: \beta_{1} \neq \beta_{2}
\end{aligned}
$$

Bảng 4.5 cho thấy kết quả p-value $=0,04<0,05 \rightarrow$ bác bỏ Ho; chứng tỏ có ngưỡng tồn tại, mối quan hệ giữa biến FD và biến phụ thuộc là phi tuyến.

Thực hiện quá trình tương tự khi lần lượt thêm các biến kiểm soát vào mô hình, kiểm định về sự tồn tại của ngưỡng vẫn đạt $\mathrm{p}$-value < 0,05 để xác nhận có một giá trị ngưỡng tồn tại.

Bảng 4.4 cho thấy:

Trong cả 6 phương trình ước lượng, hệ số tương quan $\beta_{1}>0$ đạt ý nghĩa thống kê độ tin cậy $99 \%$, thể hiện tác động tích cực của biến FD trước ngưỡng; và hệ số tương quan $\beta_{2}<0$ đạt ý nghĩa thống kê $99 \%$, thể hiện tác động tiêu cực của biến FD sau ngưỡng, đúng như kỳ vọng.

Kết quả ngưỡng tìm thấy đối với tín dụng cho khu vực tư nhân là 8,9762\% so với GDP, ổn định trong các mô hình khi lần lượt thêm biến kiểm soát vào. Điều này cho thấy giá trị ngưỡng tìm được là đáng tin cậy. Kết quả này đã trả lời cho câu hỏi nghiên cứu 1-1 là: ngưỡng của tín dụng cho khu vực tư nhân là $8,9762 \%$ mà vượt qua 
giá trị này sự phát triển mạnh hơn của khu vực tài chính lại làm cản trở tăng trưởng của nền kinh tế. Cụ thể là:

Khi Tín dụng cho khu vực tư nhân thấp hơn $8,9762 \%$ so với GDP: Phát triển tài chính có tác động thúc đẩy tăng trưởng kinh tế. Trong điều kiện các yếu tố khác không đổi, $1 \%$ tăng thêm trong Tín dụng cho khu vực tư nhân sẽ dẫn đến tăng từ $0,594 \%$ đến $0,661 \%$ trong GDP.

Tuy nhiên khi Tín dụng cho khu vực tư nhân vượt hơn $\mathbf{8 , 9 7 6 2 \%}$ so với GDP: thì Phát triển tài chính lại gây ra tác động tiêu cực lên tăng trưởng kinh tế. Hệ số tương quan của biến Phát triển tài chính lên biến phụ thuộc bị âm có ý nghĩa thống kê với độ tin cậy cao 99\%, hàm ý rằng trong điều kiện các yếu tố khác không đổi, mở rộng tăng thêm $1 \%$ trong Tín dụng cho khu vực tư nhân sẽ làm giảm đi từ $0,0209 \%$ đến $0,0296 \%$ trong tăng trưởng GDP. Điều này có nghĩa là khi vượt qua giá trị ngưỡng, càng mở rộng tín dụng thì nền kinh tế lại bị kìm hãm, bị giảm mức tăng trưởng.

Mặc dù mức giảm này trong tăng trưởng có thể coi là nhỏ so với sự tăng trưởng mạnh mẽ của các nền kinh tế mới nổi châu Á nhưng kết quả này cung cấp bằng chứng thực nghiệm chứng minh rằng phát triển tài chính quá mức là đáng lo ngại. Đây cũng là kết quả có xác thực để các nhà hoạch định chính sách của các nước châu Á tham chiếu khi đưa ra định hướng phát triển tài chính cho quốc gia mình.

Biến kiểm soát pop thể hiện tương quan dương với tăng trưởng kinh tế, đạt ý nghĩa thống kê với độ tin cậy 99\%. Kết quả này cũng phù hợp với thực tiễn của các nước châu Á, nơi mà đa số các nước còn lạc hậu về trình độ khoa học công nghệ và có lực lượng lao động dồi dào, số lượng lực lượng lao động tác động đến năng lực sản xuất của nền kinh tế, nhân tố lao động càng tăng thì GDP càng tăng.

Đối với biến thu nhập (income) và đầu tư (invest), kết quả đều nhất quán ở các phương trình và phản ánh tác động tích cực lên tăng trưởng kinh tế đạt ý nghĩa thống kê. Điều này tương đồng với quan điểm của các mô hình tăng trưởng kinh tế trong lý thuyết, nhất là trong bối cảnh các nước châu Á đang phát triển và thị trường mới nổi. 
Nền kinh tế tăng trưởng đi cùng với biểu hiện tăng mức thu nhập bình quân đầu người trong cùng kỳ, nên mối tương quan là dương.

Đầu tư gia tăng góp phần thúc đẩy sản xuất kinh doanh, hình thành cơ sở hạ tầng, làm tăng trưởng kinh tế. Khi mức đầu tư tích lũy vốn so với GDP tăng $1 \%$ sẽ thúc đẩy tăng trưởng kinh tế gia tăng từ $0,127 \%$ đến $0,137 \%$. Tác động tích cực này của đầu tư rất đáng lưu ý bởi vì nó ảnh hưởng mạnh mẽ lên tăng trưởng kinh tế, đồng thời cũng gián tiếp cho thấy rằng một hệ thống tài chính vận hành tốt và hiệu quả các chức năng của nó thì cũng góp phần tạo điều kiện thuận lợi để gia tăng đầu tư. Như vậy, phát triển tài chính không chỉ trực tiếp có vai trò quan trọng đối với tăng trưởng kinh tế mà còn là nền tảng hỗ trợ cho các nhân tố khác trong nền kinh tế tạo ảnh hưởng tích cực lên tăng trưởng kinh tế.

Bên cạnh đó, biến trễ 1 kỳ của biến income lại thể hiện tương quan âm với tăng trưởng kinh tế nhưng không mâu thuẫn với kết quả của biến income, lý do là vì trong mẫu của nghiên cứu này cũng có các nền kinh tế phát triển như Nhật, Hàn Quốc, Nga,... và thực tiễn đã cho thấy các nước đã phát triển (có mức GDP đầu người kỳ trước cao) thì mức tăng trưởng sẽ chậm lại. Trong các nghiên cứu trước đây liên quan đến nhân tố thu nhập bình quân đầu người và tăng trưởng cũng có kết quả tương đồng về mối quan hệ tỷ lệ nghịch có độ trễ này.

Kết hợp phân tích cùng với biến kiểm soát tradeop thể hiện mức độ tự do hóa thương mại của nền kinh tế, chúng ta tìm thấy kết luận tương đồng với các tài liệu nghiên cứu trước đây, đó là: tự do hóa thương mại càng nhiều (hay độ mở thương mại càng lớn) thì càng thúc đẩy tăng trưởng kinh tế. Hệ số tương quan của biến tradeop đạt mức ý nghĩa $1 \%$ và cho thấy: khi độ mở thương mại so với GDP tăng $1 \%$ sẽ thúc đẩy nền kinh tế tăng trưởng GDP trung bình từ $0,0258 \%$ đến $0,0277 \%$. Tác động tích cực này được ghi nhận cũng phù hợp với thực tiễn của các nền kinh tế đang phát triển châu Á và phù hợp với một số kết quả thực nghiệm trong những nghiên cứu trước đây (Dollar, 1992; Ben-David, 1993; Sachs và Warner, 1995; Harrison, 
1996; Edwards, 1998; Frankel và Romer, 1999; Easterly và Levine, 2001; Irwin và Tervio, 2002; Dollar và Kraay, 2003).

Rõ ràng, với các chính sách khuyến khích tự do hóa thương mại, toàn cầu hóa, cũng như sự liên kết thương mại giữa nhiều quốc gia khác nhau sẽ là điều kiện thuận lợi đối với tăng trưởng kinh tế. Có thể kể đến như thị trường xuất khẩu được mở rộng, tiếp thu được những tiến bộ khoa học công nghệ từ những quốc gia phát triển, thu hút thêm những nhà đầu tư nước ngoài... Đặc biệt, đối với những quốc gia mà trình độ phát triển về kinh tế còn thấp như Việt Nam thì điều này chính là một cơ hội to lớn để hội nhập vào xu thế phát triển chung của nền kinh tế quốc tế. Cũng nhận thấy rằng, các quốc gia trong mẫu có độ mở thương mại cao, chiếm trung bình 94,69\% GDP. Mức độ tự do hóa thương mại cao này đem lại cơ hội và thúc đẩy tăng trưởng cho nền kinh tế, tuy nhiên khi có các cú sốc bất thường về kinh tế vĩ mô trên thế giới thì các nền kinh tế châu Á này nhưng cũng là đối tượng hấp thu các tác động tiêu cực của các cú sốc khá lớn. Mức độ mở cửa nền kinh tế và tự do hóa thương mại cao này cũng góp phần lý giải vì sao khi khủng hoảng tài chính toàn cầu 2008 xảy ra, các nền kinh tế châu Á gánh chịu hậu quả tiêu cực, làm suy giảm đáng kể mức tăng trưởng kinh tế trong năm 2009-2010.

Trong các phương trình, chi tiêu chính phủ thể hiện tác động tiêu cực có ý nghĩa thống kê lên tăng trưởng kinh tế. Kết luận này ngược với những gì tìm thấy tại các nước đã phát triển châu Âu. Điều này có thể được giải thích là bởi vì vốn đầu tư vào cơ sở hạ tầng ở các quốc gia châu Á này chưa thực sự được quản lý hiệu quả, việc đầu tư còn dàn trải, đôi khi sai lệch mục tiêu nên không khuyến khích tăng trưởng kinh tế mà còn làm tiêu hao nguồn lực của quốc gia. Rajkumar và Swaroop (2008) đã chỉ ra rằng với các quốc gia có quản trị công tốt thì chi tiêu chính phủ mới đưa đến các thành quả kinh tế tốt hơn.

Kết luận này là quan trọng đối với các nhà quản lý của chính phủ các quốc gia châu Á đang phát triển trong đó có Việt Nam trong việc hoạch định chiến lược và 
thực hiện xây dựng cơ sở hạ tầng, phải đúng trọng tâm và mục tiêu thì mới có thể là động lực cho tăng trưởng kinh tế.

Bên cạnh vốn vật chất, ngày nay vốn con người đã trở thành yếu tố quan trọng có liên quan đến tăng trưởng của nền kinh tế, tuy nhiên trong các phương trình ước lượng ở bảng 4.4 thì biến mys đo lường bằng số năm đi học trung bình cho kết quả không đạt ý nghĩa thống kê. Law và Singh (2014) nghiên cứu trên 87 quốc gia trên thế giới cũng có kết quả tương tự, là không đạt ý nghĩa thống kê. Có thể là do việc đến trường học của người dân nhiều quốc gia trong mẫu chưa thực sự có hiệu quả nâng cao kiến thức hay kỹ năng cho người lao động, cũng không khuyến khích các ý tưởng đổi mới hay phát triển công nghệ để tăng chất lượng lao động và thúc đẩy hiệu quả sản xuất.

Nỗ lực thay đổi cách đo lường nhân tố này, luận án thực hiện phương trình ước lượng (6a) là thay biến mys bằng biến hci, bởi vì cho đến nay bản thân khái niệm nguồn vốn con người cũng đang được định nghĩa theo nhiều cách khác nhau, cho nên các thước đo đại diện cho nguồn vốn con người cũng như các thành phần cấu thành nên nó cũng khá đa dạng. Biến hci để đại diện cho nhân tố nguồn vốn con người, đo lường bằng chỉ số phát triển con người $\mathrm{HDI}$ của Chương trình phát triển Liên hiệp quốc (UNDP). Nó kết hợp "chỉ số tuổi thọ", "chỉ số giáo dục" và "chỉ số thu nhập”. Nếu tất cả các chỉ số này có xu hướng gia tăng trong một khoảng thời gian dài, thì sẽ được phản ánh trong xu hướng tăng của HDI. Vốn con người được mở rộng nhờ sức khoẻ, giáo dục và chất lượng sống. Các thành phần của HDI có liên quan trực tiếp đến việc hình thành vốn con người của một quốc gia. Kết quả là: biến hci cho thấy tác động cùng chiều với biến tăng trưởng kinh tế nhưng đáng tiếc vẫn không đạt ý nghĩa thống kê, tức là không xác nhận được mối quan hệ của nhân tố này với tăng trưởng kinh tế.

Ngoài biến mys thì biến infla (nhân tố lạm phát) và biến inst (thể chế) cũng không đạt ý nghĩa thống kê. Đây cũng là phần còn hạn chế của nghiên cứu này là 
chưa phân tích được các thể chế chính trị khác biệt như ở Việt Nam hay Trung Quốc có ảnh hưởng gì đến tăng trưởng kinh tế hay không.

\subsubsection{Tín dụng trong nước}

Thay thế cách đo lường biến FD bằng Tỷ số Tín dụng trong nước trên GDP, thực hiện hồi quy ngưỡng và kiểm định tương tự, kết quả được trình bày trong các bảng 4.6 và 4.7

Bảng 4.6 Kiểm định sự tồn tại của ngưỡng khi FD =Tín dụng trong nước /GDP

$$
\begin{aligned}
& \text { Threshold estimator (level }=95) \\
& \text { Threshold Lower Upper } \\
& 8,8641 \quad 8,1817 \quad 9,2651
\end{aligned}
$$

Threshold effect test $($ bootstrap $=30)$ :

Threshold RSS MSE Fstat Prob Crit10 Crit5 Crit1

\begin{tabular}{llllllll} 
Single & 2680.9759 & 6,9817 & 15,65 & 0,0667 & 13,0622 & 22,535 & 32,2470 \\
\hline
\end{tabular}

Nguồn: Tác giả tính toán

Bảng 4.6 cho thấy p-value $=0,0667<0,1 \rightarrow$ bác bỏ Ho; cho thấy tồn tại giá trị ngưỡng. Giá trị ngưỡng của Tín dụng trong nước so với GDP là $8,8641 \%$. Kết quả tồn tại ngưỡng có ý nghĩa thống kê với độ tin cậy $90 \%$ và chỉ có một ngưỡng. 
Trang 93

Bảng 4.7 Kết quả hồi quy ngưỡng với FD = Tín dụng trong nước /GDP

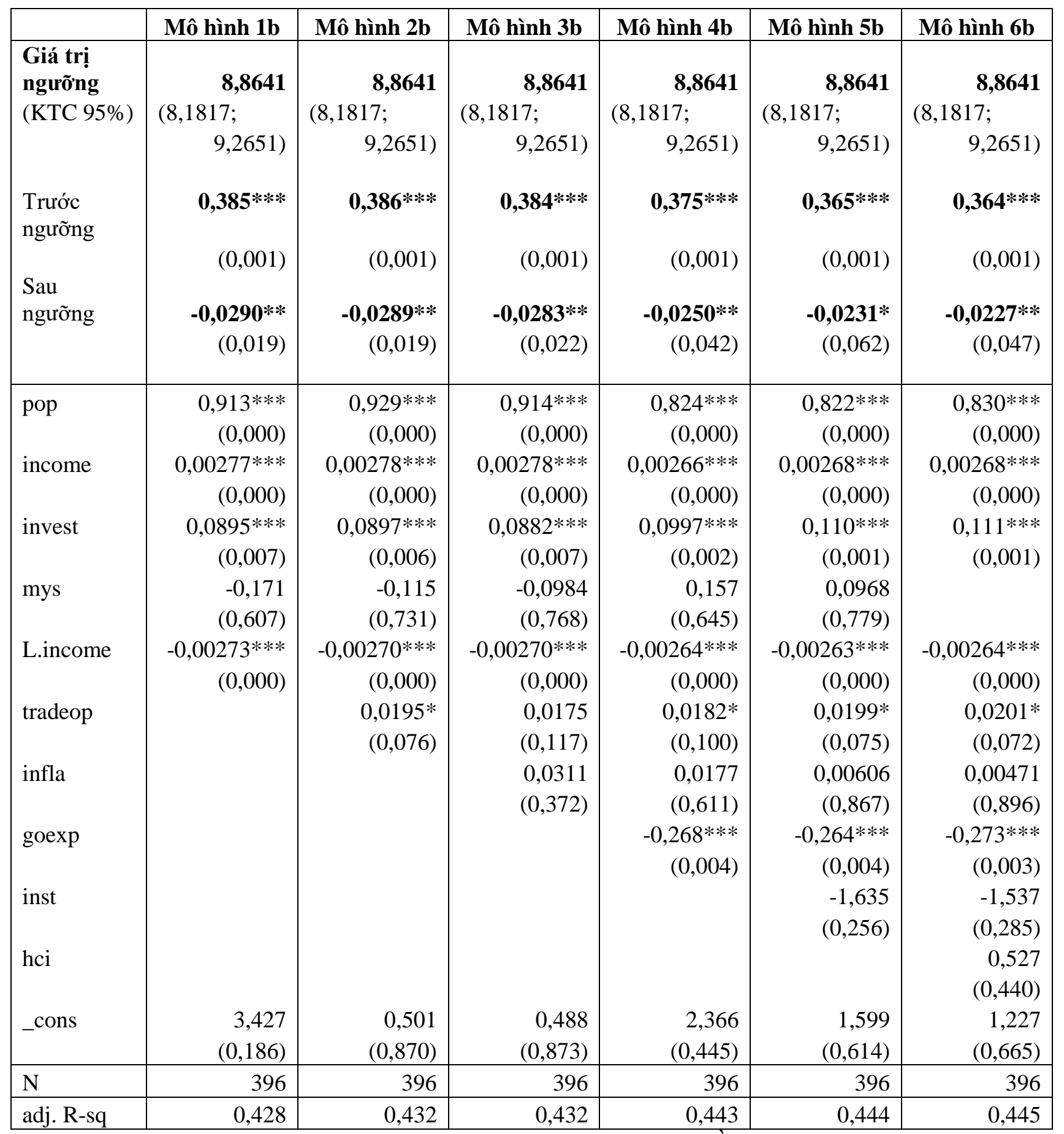

$* \mathrm{p}<0,1 * * \mathrm{p}<0,05 * * * \mathrm{p}<0,01 \quad$ Nguồn: Tác giả tính toán

Kết quả hệ số tương quan trước và sau giá trị ngưỡng trong bảng 4.7 đều đạt ý nghĩa thống kê và thể hiện tác động chuyển từ (+) sang (-) 
So sánh kết quả trong bảng 4.7 và 4.4 cho thấy kết quả tìm thấy ổn định và tương đồng với nhau. Kết quả này đã trả lời cho câu hỏi nghiên cứu 1-2 là: ngưỡng của tín dụng trong nước là $8,8641 \%$ so với GDP, mà vượt qua giá trị này sự phát triển mạnh hơn của khu vực tài chính lại làm cản trở tăng trưởng của nền kinh tế.

Khi Tín dụng trong nước thấp hơn $8,8641 \%$ so với GDP: Phát triển tài chính có tác động thúc đẩy tăng trưởng kinh tế. Trong điều kiện các yếu tố khác không đổi, $1 \%$ tăng thêm trong Tín dụng trong nước sẽ dẫn đến tăng từ $0,364 \%$ đến $0,386 \%$ trong GDP. Tuy nhiên khi Tín dụng trong nước vượt hơn 8,8641\% so với GDP: thì Phát triển tài chính lại gây ra tác động tiêu cực lên tăng trưởng kinh tế. Hệ số tương quan của biến Phát triển tài chính lên biến phụ thuộc bị âm có ý nghĩa thống kê với độ tin cậy $95 \%$, hàm ý rằng trong điều kiện các yếu tố khác không đổi, mở rộng tăng thêm $1 \%$ trong Tín dụng trong nước sẽ làm giảm đi từ $0,0227 \%$ đến 0,0290\% trong tăng trưởng GDP.

Tương quan giữa các biến giải thích khác lên biến phụ thuộc vẫn tương đồng cả về dấu của hệ số tương quan lẫn ý nghĩa thống kê đạt được như đã tìm thấy khi hồi quy với Tỷ số Tín dụng cho khu vực tư nhân.

\subsubsection{Nọ thanh khoản /GDP}

Tương tự, tiếp tục thay thế cách đo lường biến FD bằng Tỷ số nợ thanh khoản/GDP, kết quả được trình bày trong bảng 4.8 và 4.9

Bảng 4.8 Kiểm định sự tồn tại của ngưỡng khi FD = Nọ̣ thanh khoản /GDP

\begin{tabular}{|c|c|c|c|c|c|c|c|}
\hline \\
\hline \multicolumn{8}{|c|}{$\begin{array}{c}\text { Threshold estimator }(\text { level }=95) \\
\text { Threshold Lower }\end{array}$} \\
\hline \multicolumn{3}{|c|}{$18,4802 \quad 17,9976$} & \multicolumn{5}{|l|}{19,6984} \\
\hline \multicolumn{8}{|c|}{ Threshold effect test $($ bootstrap $=50)$ : } \\
\hline Threshold & RSS & MSE & Fstat & Prob & Crit10 & Crit5 & Crit1 \\
\hline Single & 2437,2617 & 6,347 & 36,99 & 0,0200 & 15,9471 & 21,8228 & 47,0449 \\
\hline
\end{tabular}

Nguồn: Tác giả tính toán 
Trang 95

Bảng 4.9 Kết quả hồi quy ngưỡng với FD = Cung tiền M3 /GDP

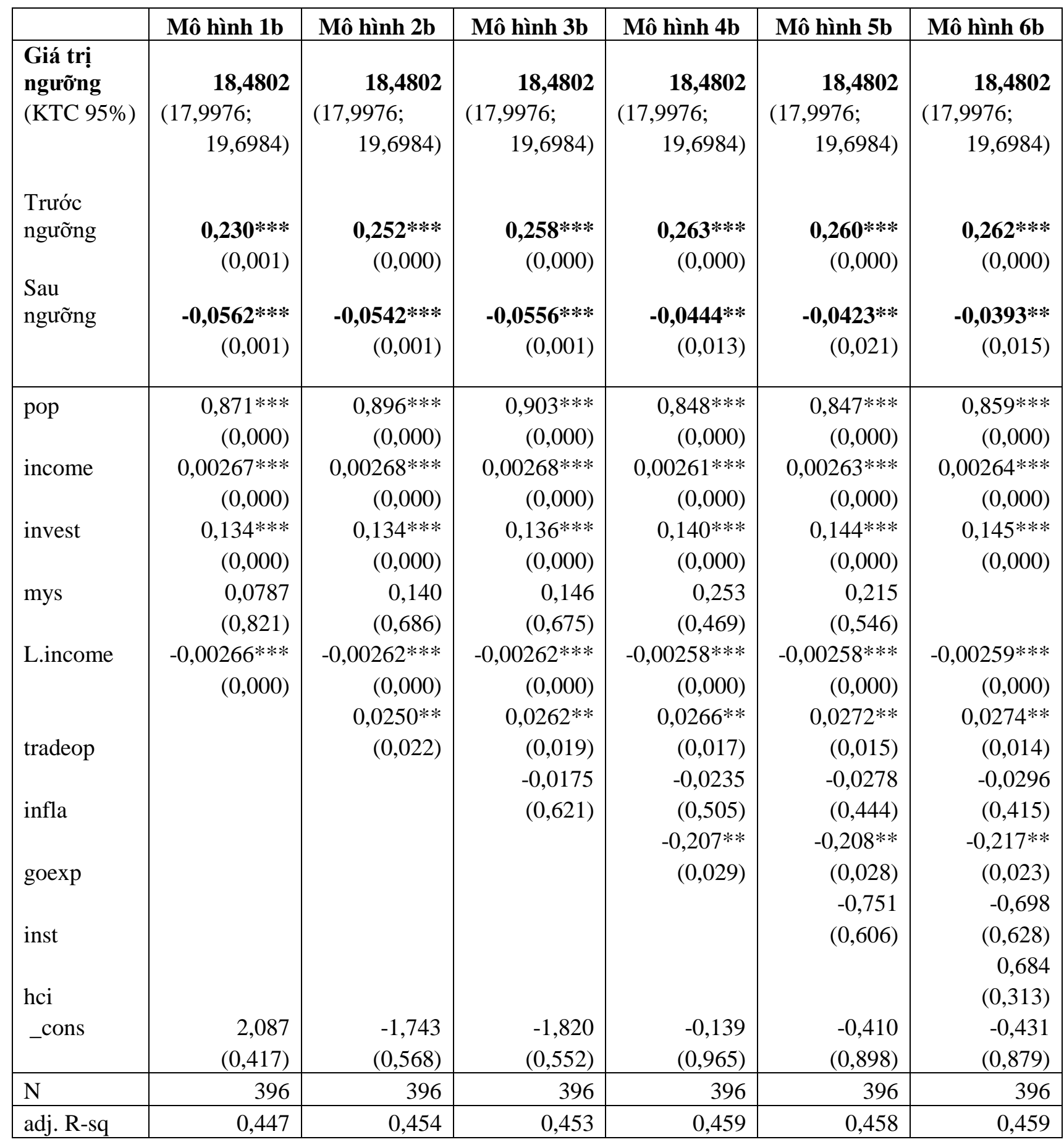

$* \mathrm{p}<0,1 * * \mathrm{p}<0,05 * * * \mathrm{p}<0,01$

Nguồn: Tác giả tính toán 
Bảng 4.8 cho thấy p-value $=0,02<0,05$ bác bỏ Ho, cho thấy tồn tại giá trị ngưỡng. Khi đo lường sự phát triển tài chính bằng tỷ lệ cung tiền mở rộng $\mathrm{M} 3$ so với GDP thì giá trị ngưỡng của nó là 18,4802 \%. Giá trị ngưỡng tìm được này ổn định qua các mô hình hồi quy lần lượt là bốn biến kiểm soát cơ bản, sau đó lần lượt thêm biến kiểm soát vào mô hình đều cho thấy kết quả tồn tại ngưỡng có ý nghĩa thống kê với độ tin cậy 95\% và chỉ có một ngưỡng.

Một lần nữa, kết quả tìm thấy khi thay thế cách đo lường biến FD bằng chỉ tiêu Nợ thanh khoản đã chứng minh rằng vai trò của Phát triển tài chính đối với Tăng trưởng kinh tế không luôn luôn là tích cực và thúc đẩy cho tăng trưởng, mà mối quan hệ này là phi tuyến và tồn tại điểm chuyển tiếp. Các kết quả về hệ số tương quan trước và sau giá trị ngưỡng của biến FD trong bảng 4.9 đều có ý nghĩa thống kê và thể hiện sự biến chuyển tác động từ $(+)$ sang $(-)$. Khi cung tiền M3/GDP dưới mức $18,4802 \%$, thì $1 \%$ tăng thêm trong cung tiền sẽ thúc đẩy nền kinh tế tăng trưởng $0,23 \%$ đến $0,63 \%$ trong điều kiện các yếu tố khác không thay đổi. Tuy nhiên nếu cung tiền $\mathrm{M} 3$ vượt mức ngưỡng thì $1 \%$ tăng thêm trong cung tiền lại làm giảm tăng trưởng kinh tế $0,0393 \%$ đến $0,0562 \%$. Kết quả hồi quy của các biến số khác trong mô hình tương tự kết quả đã tìm được ở phần trước.

Bảng 4.10, 4.11 và 4.12 tóm tắt kết quả hồi quy, tóm tắt giá trị ngưỡng khi biến đại diện cho Phát triển tài chính khi nó được đo lường thông qua ba chỉ tiêu. 
Bảng 4.10 Tóm tắt kết quả hồi quy ngưỡng (bank-based)

\begin{tabular}{|c|c|c|c|}
\hline & $\begin{array}{c}\text { FD= Tín dụng tur } \\
\text { nhân/GDP }\end{array}$ & $\begin{array}{c}\text { FD= Tín dụng trong } \\
\text { nước/GDP }\end{array}$ & $\begin{array}{c}\text { FD= Nọ' thanh } \\
\text { khoản/GDP }\end{array}$ \\
\hline $\begin{array}{l}\text { Giá trị ngưỡng: } \\
\text { (KTC 95\%) }\end{array}$ & $\begin{array}{c}8,9762 \\
(8,4427 ; 9,3103)\end{array}$ & $\begin{array}{c}8,8641 \\
(8,1817 ; 9,2651)\end{array}$ & $\begin{array}{c}18,4802 \\
(17,9976 ; 19,6984)\end{array}$ \\
\hline \multicolumn{4}{|l|}{ Tác động của FD: } \\
\hline \multirow[t]{2}{*}{ Trước ngưỡng } & $0,594 * * *$ & $0,365^{* * *}$ & $0,260 * *$ \\
\hline & $(0,000)$ & $(0,001)$ & $(0,000)$ \\
\hline \multirow[t]{2}{*}{ Sau ngưỡng } & $-0,0209 * * *$ & $-0,0231^{*}$ & $-0,0423 * *$ \\
\hline & $(0,152)$ & $(0,062)$ & $(0,021)$ \\
\hline \multirow[t]{2}{*}{ pop } & $0,894 * * *$ & $-0,822 * * *$ & $0,847 * * *$ \\
\hline & $(0,000)$ & $(0,000)$ & $(0,000)$ \\
\hline \multirow[t]{2}{*}{ income } & $0,00269 * * *$ & $0,00268 * * *$ & $0,00263 * * *$ \\
\hline & $(0,000)$ & $(0,000)$ & $(0,000)$ \\
\hline \multirow[t]{2}{*}{ invest } & $0,137 * * *$ & $0,110 * * *$ & $0,144 * * *$ \\
\hline & $(0,000)$ & $(0,001)$ & $(0,000)$ \\
\hline \multirow[t]{2}{*}{ l.income } & $-0,0026 * * *$ & $-0,0026 * * *$ & $-0,0026^{* * *}$ \\
\hline & $(0,000)$ & $(0,000)$ & $(0,000)$ \\
\hline \multirow[t]{2}{*}{ tradeop } & $0,0265 * * *$ & 0,0199* & $0,0272 * * *$ \\
\hline & $(0,019)$ & $(0,075)$ & $(0,015)$ \\
\hline \multirow[t]{2}{*}{ infla } & 0,0113 & 0,006 & $-0,0278$ \\
\hline & $(0,756)$ & $(0,867)$ & $(0,444)$ \\
\hline \multirow[t]{2}{*}{ goexp } & $-0,197 * * *$ & $-0,264 * * *$ & $-0,208 * *$ \\
\hline & $(0,039)$ & $(0,004)$ & $(0,028)$ \\
\hline \multirow[t]{2}{*}{ inst } & $-1,016$ & $-1,635$ & $-0,751$ \\
\hline & $(0,486)$ & $(0,256)$ & $(0,606)$ \\
\hline \multirow[t]{2}{*}{ mys } & $-0,0377$ & 0,0968 & 0,215 \\
\hline & $(0,911)$ & $(0,779)$ & $(0,546)$ \\
\hline Số quan sát & 396 & 396 & 396 \\
\hline $\operatorname{Adj}-R^{2}$ & 0,446 & 0,444 & 0,458 \\
\hline
\end{tabular}

$* \mathrm{p}<0,1, * * \mathrm{p}<0,05, * * * \mathrm{p}<0,01$ 
Bảng 4.11 Kết quả hồi quy ngưỡng với nguồn vốn con người đo bằng HDI

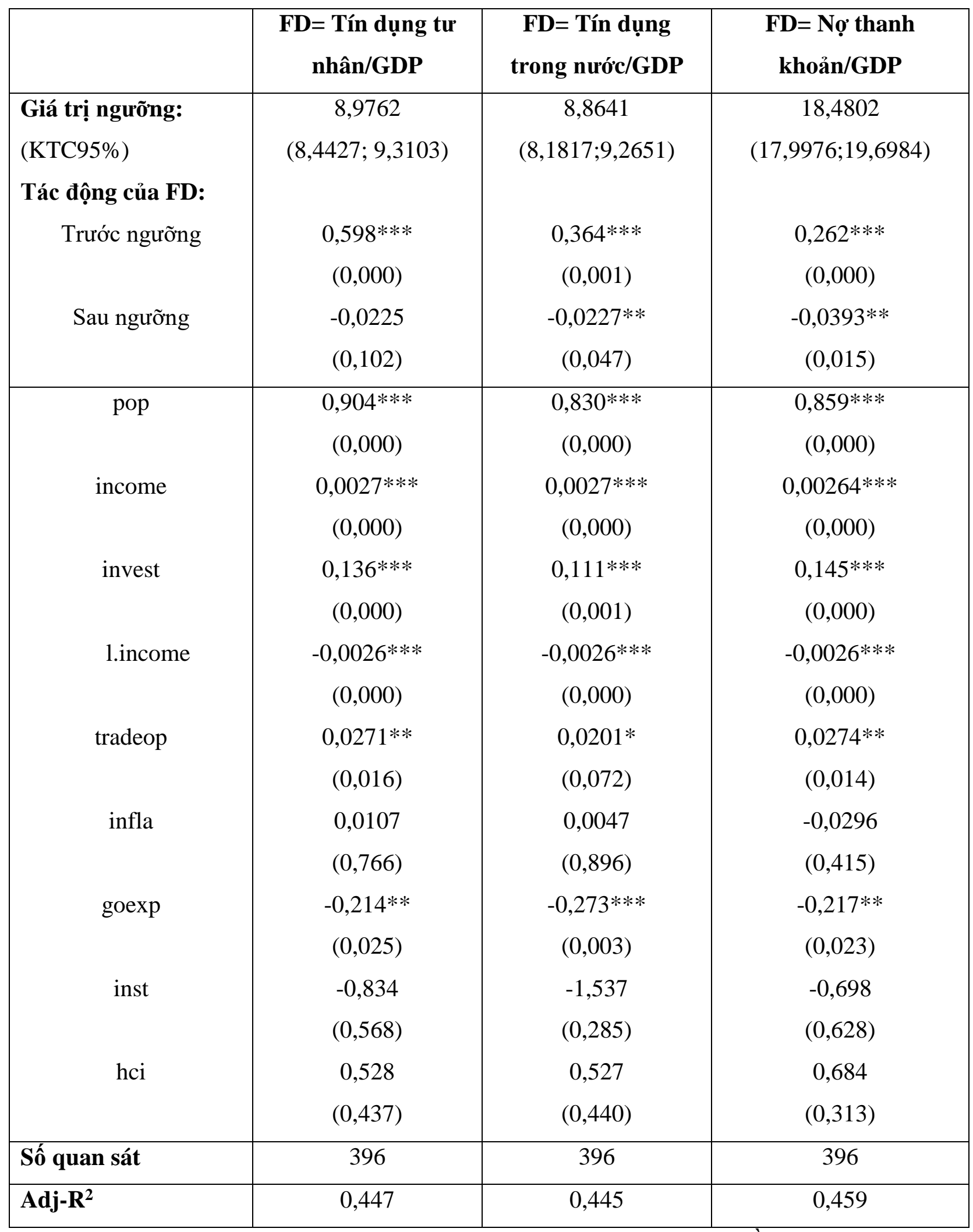

$* \mathrm{p}<0,1, * * \mathrm{p}<0,05, * * * \mathrm{p}<0,01$ 
Trang 99

Bảng 4.12 Giá trị ngưỡng của Phát triển tài chính (bank-based)

\begin{tabular}{cccc}
\hline Phát triển tài chính & Ngưỡng & Giá trị thấp nhất & Giá trị cao nhất \\
\hline Tín dụng tư nhân/GDP & 8,9762 & 8,4427 & 9,3103 \\
Tín dụng trong nước/GDP & 8,8641 & 8,1817 & 9,2651 \\
Cung tiền M3/GDP & 18,4802 & 17,9976 & 19,6984
\end{tabular}

Nguồn: Tác giả tính toán

Dù thay đổi cách đo lường biến số FD, kết quả hồi quy ngưỡng vẫn nhất quán và có ý nghĩa thống kê. Kết quả tìm thấy của luận án này khác biệt xa so với Cecchetti và Kharroubi (2012) khi các nhà nghiên cứu này xác lập giá trị ngưỡng cho tín dụng dành cho khu vực tư nhân lên đến $90 \%$ so với GDP, cũng khác với Arcand và cộng sự (2012) khi họ cho rằng khi tín dụng dành cho khu vực tư nhân vượt 110\% mới gây ra tác động tiêu cực của "quá nhiều tài chính". Thật ra, các nhà nghiên cứu nói trên có thể được coi là những người có công lao đầu tiên xác lập vấn đề là không nên phát triển hệ thống tài chính quá mức cho phép, tuy nhiên các kết quả tìm ra của họ có phần áp đặt khi cho rằng quan hệ phi tuyến tức là mối quan hệ hồi quy bậc hai. Hơn nữa, ước lượng hồi quy của các tác giả này dùng Pooled OLS mà chưa xử lý được các vấn đề có thể phát sinh làm sai lệch kết quả khi các giả thiết của OLS không thỏa.

Các kết quả hồi quy ngưỡng của luận án đã trả lời cho câu hỏi nghiên cứu 11, 1-2, 1-3 là xác định giá trị ngưỡng cụ thể của Phát triển tài chính, xác nhận giả thuyết $\mathrm{H} 1$ là có tồn tại tại một giá trị của phát triển tài chính mà trước và sau giá trị ngưỡng này, tác động của phát triển tài chính lên tăng trưởng kinh tế thay đổi từ tích cực sang tiêu cực. Đồng thời trên cơ sở dữ liệu về khu vực ngân hàng cũng đã trả lời cho câu hỏi nghiên cứu số 2 và số 3 là chiều có tác động và mức độ tác động cụ thể của Phát triển tài chính lên tăng trưởng kinh tế của các quốc gia châu Á.

\subsubsection{Kết quả ước lượng system-GMM}

Trong hồi quy, một trong những quan ngại của nhà nghiên cứu là vấn đề nội sinh, Vấn đề nội sinh thường xảy ra do ba nguyên nhân sau đây: do sai sót trong số liệu, do bỏ sót biến, và do biến phụ thuộc cũng có tác động lên biến độc lập - tức là tăng trưởng kinh tế ngược lại cũng gây ra tác động đồng thời lên phát triển tài chính. 
Mặc dù có một số quan điểm cho rằng khi nền kinh tế tăng trưởng tạo ra những nhu cầu dẫn dắt hệ thống tài chính phát triển theo nhưng Hsueh và cộng sự (2013) trong nghiên cứu về 10 quốc gia châu Á đăng trên tạp chí Economic Modelling (là tạp chí được xếp hạng $\mathrm{Q} 2$ trên thế giới) đã chứng minh rằng chỉ tìm thấy tác động nhân quả một chiều từ phát triển tài chính lên tăng trưởng kinh tế chứ không có chiều ngược lại từ tăng trưởng kinh tế lên phát triển tài chính của 7 nước trong mẫu gồm Malaysia, Indonesia, Korea, Singapore, Thailand, Taiwan, và China. Bên cạnh đó đối với 3 nước còn lại trong mẫu là Philippines, India, và Japan thì không tìm được quan hệ nhân quả nào giữa hai biến số trên. Hơn nữa, các nhân tố nào ảnh hưởng đến phát triển tài chính không thuộc phạm vi nghiên cứu của luận án này. Tuy nhiên để củng cố thêm tính vững cho kết luận tìm thấy từ thực nghiệm, luận án thực hiện ước lượng lại các mô hình nói trên bằng phướng pháp ước lượng system-GMM, giúp giải quyết vấn đề có thể phát sinh trong mô hình như nội sinh, tự tương quan, phương sai thay đổi.

Trên cơ sở ngưỡng đã xác định bằng Panel Threshold Regression (kết quả ngưỡng được trình bày trong bảng 4.12) luận án thực hiện ước lượng hồi quy bằng system-GMM như là một phương pháp phân tích thay thế để trả lời cho cùng một vấn đề nghiên cứu, cũng nhằm mục đích để củng cố cho tính vững của kết quả tìm được.

Biến giả thred được tạo ra, sẽ nhận giá trị =1 nếu quan sát có giá trị biến FD lớn hơn giá trị ngưỡng, và nhận giá trị $=0$ nếu quan sát có giá trị biến FD dưới ngưỡng. Cụ thể là lần lượt xem xét ba tình huống:

- Đo lường FD = tỷ số tín dụng cho khu vực tư nhân /GDP thì thred=1 khi tỷ số này $>8,9762$

- Tương tự, thred $=1$ khi tỷ số tín dụng trong nước /GDP > 8,8641

- Và thred =1 khi tỷ số cung tiền M3/GDP > 18,4802

Sau đó tạo biến tương tác $\mathrm{tt}=$ thred*FD và thực hiện ước lượng phương trình (3.3) bằng system-GMM theo Arellano và Bond (1991). Kết quả ước lượng được trình bày trong phần tiếp theo. 
Bảng 4.13 Kết quả system-GMM (bank-based)

\begin{tabular}{|c|c|c|c|}
\hline & Mô hình 1 & Mô hình 2 & Mô hình 3 \\
\hline & $\begin{array}{c}\text { FD=Tín dụng tư } \\
\text { nhân/GDP }\end{array}$ & $\begin{array}{l}\text { FD= Tín dụng } \\
\text { trong nước/GDP }\end{array}$ & $\begin{array}{c}\text { FD= Nơ thanh } \\
\text { khoản/GDP }\end{array}$ \\
\hline privatecre & $\begin{array}{r}0,761 * * * \\
(0,000)\end{array}$ & & \\
\hline $\mathrm{tt} 1$ & $\begin{array}{r}-0,775 * * * \\
(0,000)\end{array}$ & & \\
\hline domescre & & $\begin{array}{r}0,466^{* * *} \\
(0,008)\end{array}$ & \\
\hline $\mathrm{tt} 2$ & & $\begin{array}{r}-0,484 * * * \\
(0,006)\end{array}$ & \\
\hline liq & & & $\begin{array}{r}0,180 * * * \\
(0,005)\end{array}$ \\
\hline $\mathrm{tt} 3$ & & & $\begin{array}{r}-0,184 * * * \\
(0,002)\end{array}$ \\
\hline pop & $\begin{array}{r}0,978 * * * \\
(0,000)\end{array}$ & $\begin{array}{r}0,741 * * * \\
(0,000)\end{array}$ & $\begin{array}{r}0,866 * * * \\
(0,000)\end{array}$ \\
\hline income & $\begin{array}{r}0,00348 * * * \\
(0,000)\end{array}$ & $\begin{array}{r}0,00271 * * * \\
(0,000)\end{array}$ & $\begin{array}{r}0,00276^{* * * *} \\
(0,000)\end{array}$ \\
\hline invest & $\begin{array}{r}0,115 * * * \\
(0,000)\end{array}$ & $\begin{array}{r}0,122 * * * \\
(0,000)\end{array}$ & $\begin{array}{r}0,114 * * * \\
(0,000)\end{array}$ \\
\hline tradeop & $\begin{array}{r}-0,00510^{*} \\
(0,050)\end{array}$ & $\begin{array}{r}-0,00739 * * \\
(0,013)\end{array}$ & $\begin{array}{r}-0,00469 * * \\
(0,050)\end{array}$ \\
\hline infla & $\begin{array}{r}0,0251 \\
(0,443)\end{array}$ & $\begin{array}{r}0,0149 \\
(0,637)\end{array}$ & $\begin{array}{r}0,00796 \\
(0,799)\end{array}$ \\
\hline goexp & $\begin{array}{r}-0,158 * * * \\
(0,000)\end{array}$ & $\begin{array}{r}-0,166^{* * *} * \\
(0,000)\end{array}$ & $\begin{array}{r}-0,143 * * * \\
(0,000)\end{array}$ \\
\hline inst & $\begin{array}{r}0,518 \\
(0,420)\end{array}$ & $\begin{array}{r}0,565 \\
(0,384)\end{array}$ & $\begin{array}{r}0,0840 \\
(0,884)\end{array}$ \\
\hline mys & $\begin{array}{r}-0,152 * * \\
(0,017)\end{array}$ & $\begin{array}{r}-0,157 * * \\
(0,013)\end{array}$ & $\begin{array}{r}-0,191 * * * \\
(0,004)\end{array}$ \\
\hline L.income & $\begin{array}{r}-0,00353 * * * \\
(0,000)\end{array}$ & $\begin{array}{r}-0,00273 * * * \\
(0,000)\end{array}$ & $\begin{array}{r}-0,00279 * * * \\
(0,000)\end{array}$ \\
\hline _cons & $\begin{array}{r}4,936 * * * \\
(0,000) \\
\end{array}$ & $\begin{array}{r}6,010 * * * \\
(0,000)\end{array}$ & $\begin{array}{r}4,595 * * * \\
(0,000) \\
\end{array}$ \\
\hline $\mathrm{N}$ & 396,00 & 396,00 & 396,00 \\
\hline AR(1) p-value & 0,000 & 0,000 & 0,000 \\
\hline $\operatorname{AR}(2) \mathrm{p}$-value & 0,150 & 0,174 & 0,498 \\
\hline Sargan test & 0,189 & 0,494 & 0,124 \\
\hline
\end{tabular}


Trước giá trị ngưỡng, bảng 4.13 cũng cho thấy trong cả ba cách đo lường, hệ số tương quan của biến privatecre, biến domescre, biến liq đều dương và có ý nghĩa thống kê với độ tin cậy $99 \%$ phản ánh tác động tích cực của FD lên tăng trưởng kinh tế.

Sau giá trị ngưỡng, hệ số tác động của biến FD được xác định là $\beta^{*}=\beta_{1}+\beta_{2}$. Kết quả trong bảng 4.13 cũng thể hiện tác động này cụ thể là:

Khi đo lường FD bằng biến privatecre: $\beta^{*}=0,761+(-0,775)=-0,014$

Khi đo lường FD bằng biến domescre: $\beta^{*}=0,466+(-0,484)=-0,018$

Khi đo lường FD bằng biến liq: $\beta^{*}=0,180+(-0,184)=-0,004$

càng tăng mức độ phát triển cho khu vực tài chính thì tăng trưởng kinh tế bị chậm lại (hệ số tương quan âm).

Kiểm định giả thuyết Ho: $\left(\beta_{1}+\beta_{2}=0\right)$ để xác nhận sự tồn tại của ngưỡng được trình bày trong bảng 4.14

Bảng 4.14 Kiểm định Ho: $\left(\beta_{1}+\beta_{2}=0\right)$

\begin{tabular}{|l|c|c|c|}
\hline & $\begin{array}{c}\text { FD=Tín dụng tư } \\
\text { nhân/GDP }\end{array}$ & $\begin{array}{c}\text { FD= Tín dụng } \\
\text { trong nước/GDP }\end{array}$ & $\begin{array}{c}\text { FD= Nọ thanh } \\
\text { khoản/GDP }\end{array}$ \\
\hline p-value & $0,0000<0,01$ & $0,0116<0,5$ & $0,0969<0,1$ \\
\hline Kết luận & Tức là hệ số tương quan sau ngưỡng $\beta^{*}=\beta_{1}+\beta_{2} \neq 0$ \\
\hline
\end{tabular}

Nguồn: Tác giả tính toán

Bảng 4.14 cho thấy hệ số tương quan $\beta^{*}$ âm của biến FD sau ngưỡng có ý nghĩa thống kê, thể hiện mối quan hệ phi tuyến giữa biến FD và biến Growth. Như vậy là, trước giá trị ngưỡng, FD có tác động thúc đẩy tăng trưởng kinh tế nhưng vượt quá giá trị ngưỡng thì nó lại gây ra tác động tiêu cực, cản trở tăng trưởng kinh tế. Kết quả ước lượng bằng system-GMM giúp khẳng định sự tồn tại của giá trị ngưỡng và tác động phi tuyến của FD lên tăng trưởng của nền kinh tế. 


\subsection{Phân tích tác động phi tuyến của phát triển tài chính đến tăng trưởng kinh tế trên dữ liệu về TTCK}

Trong phần tiếp theo, luận án thực hiện mở rộng phân tích tác động của Phát triển tài chính, dùng các chỉ tiêu phản ánh sự phát triển của thị trường tài chính để đo lường biến đại diện cho nhân tố Phát triển tài chính, Tuy nhiên mẫu phải loại bỏ các quốc gia hoàn toàn không có thị trường chứng khoán hoặc thiếu dữ liệu vì mô hình hồi quy ngưỡng trên Fixed Effect đòi hỏi dữ liệu phải là dạng bảng cân bằng (balanced panel). Kết quả được lần lượt trình bày trong các bảng tiếp theo.

\subsubsection{Kết quả hồi quy ngưỡng}

\subsubsection{Quy mô vốn hóa thị truòng}

Bảng 4.15 Kiểm định giá trị ngưỡng khi FD= quy mô vốn hóa TTCK/GDP

Threshold estimator $($ level $=95)$

Threshold Lower Upper

$81,8477 \quad 72,4982 \quad 81,9182$

Threshold effect test $($ bootstrap $=30$ ):

Threshold RSS MSE Fstat Prob Crit10 Crit5 Crit1 $\begin{array}{llllllll}\text { Single } & 915,6637 & 3,6336 & 10,68 & 0,0000 & 8,9285 & 10,5239 & 10,6843\end{array}$

Nguồn: Tác giả tính toán

Bảng 4.15 cho thấy khi FD đo lường bằng Tỷ số quy mô vốn hóa TTCK trên GDP, tồn tại một giá trị ngưỡng = 81,8477\% đạt ý nghĩa thống kê với độ tin cậy 99\%, đồng thời chứng tỏ có tồn tại mối quan hệ phi tuyến. Tuy nhiên kết quả hồi quy ngưỡng trong bảng 4.16 cho thấy tác động của FD có thay đổi nhưng vẫn duy trì là tác động tích cực, mặc dù mức độ thúc đẩy tăng trưởng kinh tế của phát triển tài chính giảm sút. Các hệ số tương quan của biến độc lập FD trước và sau ngưỡng đều có ý nghĩa thống kê tốt, đạt độ tin cậy 99\%. Cụ thể là: Khi Quy mô vốn hóa TTCK còn dưới $81,8477 \%$ so với GDP, trong điều kiện các yếu tố khác không đổi, $1 \%$ tăng thêm trong quy mô vốn hóa thị trường sẽ thúc đẩy nền kinh tế tăng trưởng từ $0,0445 \%$ đến $0,0482 \%$. Vượt trên giá trị $81,8477 \%$ so với GDP thì tăng trưởng trong quy mô vốn hóa TTCK vẫn tác động tích cực nhưng mức độ tác động ít hơn so với trước ngưỡng. 
Bảng 4.16 Kết quả hồi quy ngưỡng FD = Tỷ số quy mô vốn hóa TTCK/GDP

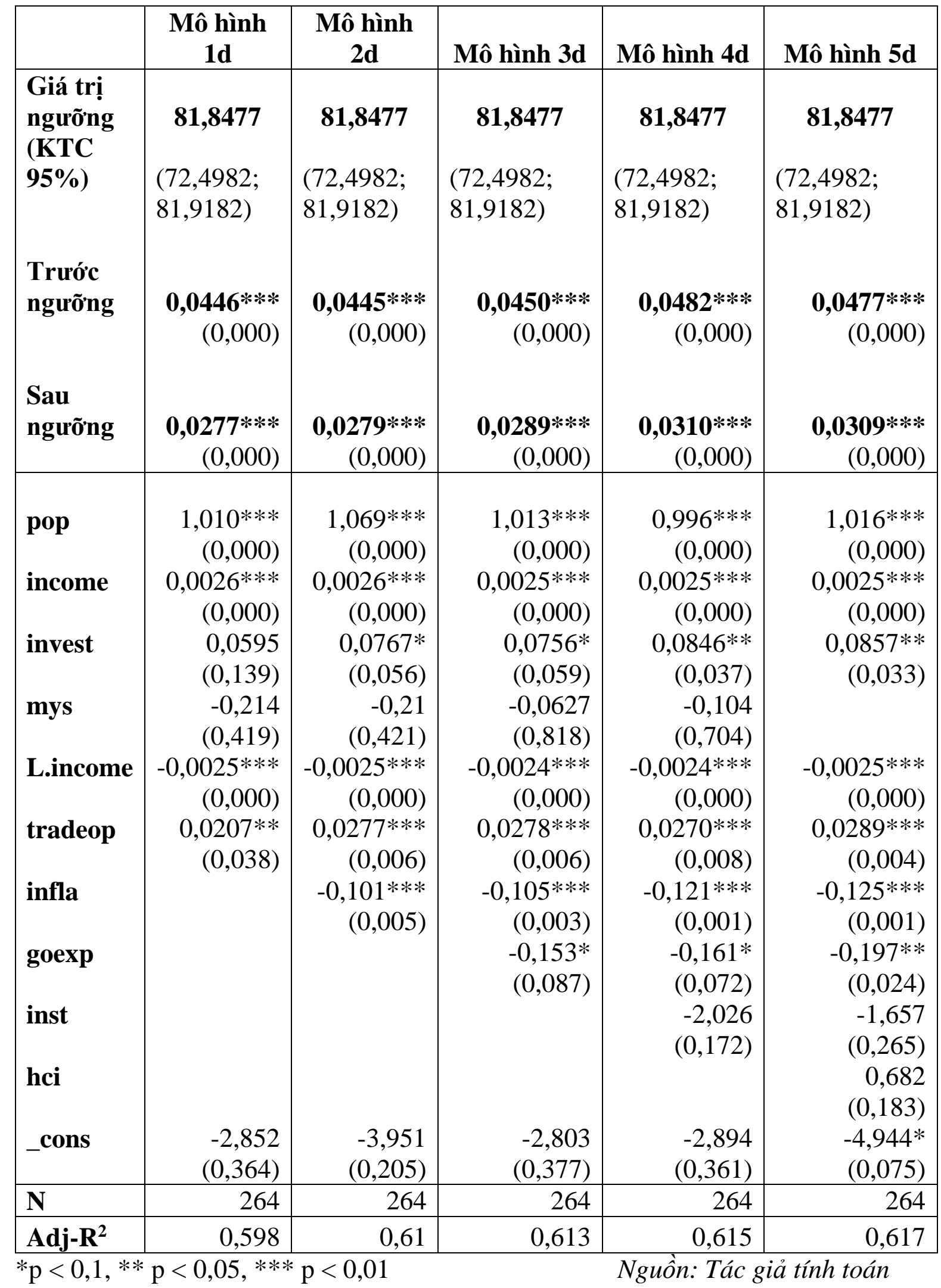


Có thể vì độ dài của chuỗi dữ liệu trong mẫu quan sát này chưa đủ để FD thể hiện đến giai đoạn gây ra tác động tiêu cực. Các quốc gia châu Á trong mẫu thì mức độ phát triển TTCK về quy mô vốn hóa của họ trong giai đoạn nghiên cứu trung bình là $68,11876 \%$ vẫn còn thấp hơn so với giá trị ngưỡng. Kết quả này hàm ý rằng các nước châu Á vẫn còn có thể phát triển TTCK cả theo chiều sâu lẫn chiều rộng để khai thác vai trò tích cực của Phát triển thị trường tài chính lên tăng trưởng kinh tế, nhưng cũng cần lưu tâm rằng vượt quá mức giới hạn ngưỡng thì không phải là một chiến lược tốt. Theo thống kê dựa trên số liệu của World Bank, quy mô vốn hóa TTCK so với GDP trung bình của các nước châu Á chỉ trong năm 2016 đã lên đến mức 102,4\%, trong đó cao nhất là thị trường Hongkong (nhưng quốc gia này không đưa vào mẫu nghiên cứu vì từ năm 1997 đã được trao trả về là một phần lãnh thổ của Trung Quốc) và thấp nhất là Sri Lanka chỉ 22,84\%. Trong mẫu nghiên cứu này, nước có quy mô vốn hóa TTCK đứng đầu là Singapore, năm 2016 đã đạt đến 206,75\% so với GDP.

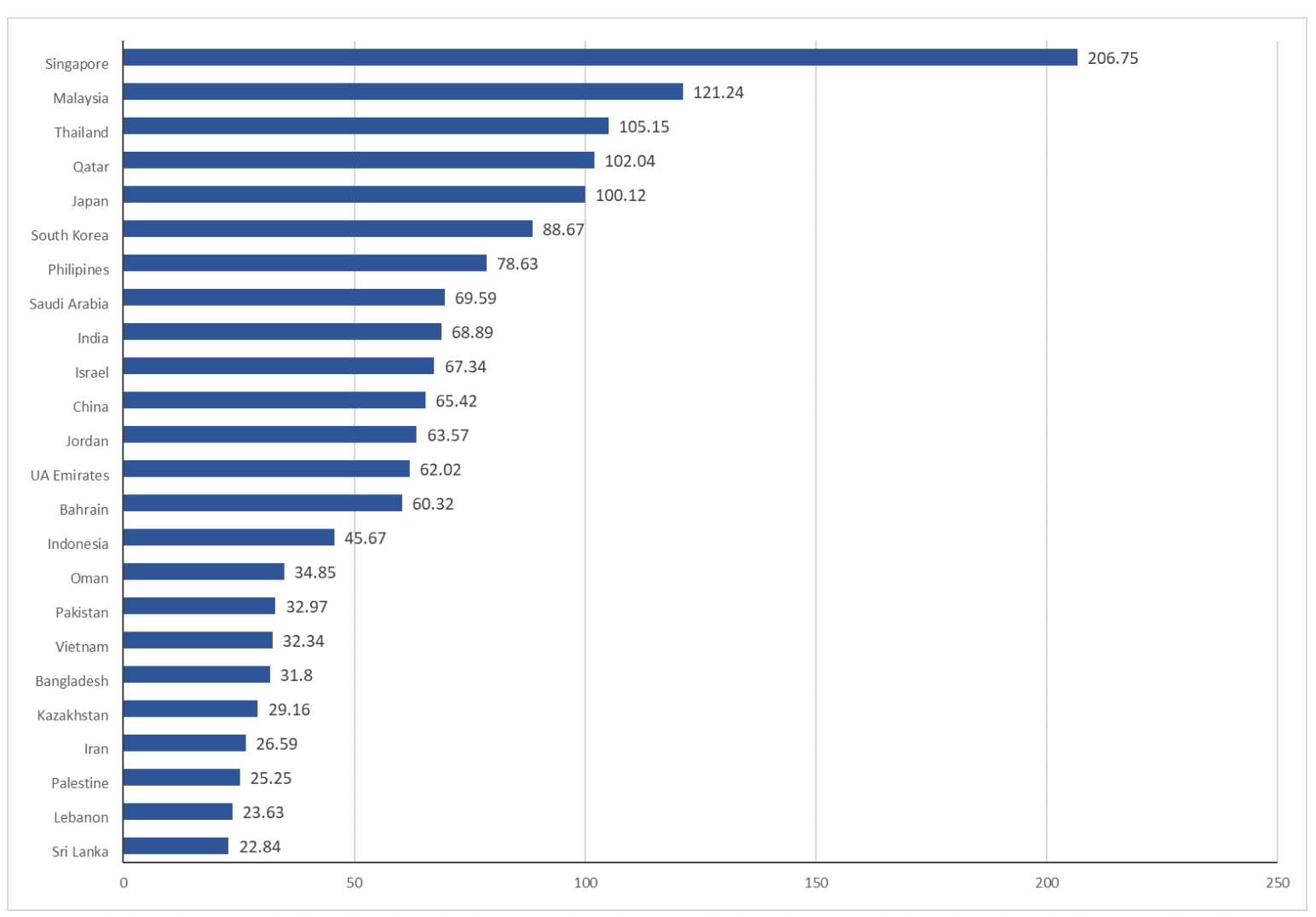

Hình 4.1 Đồ thị Quy mô vốn hóa TTCK các nước châu Á so với GDP năm 2016 Nguồn: dũ liệu của World Bank 


\subsubsection{Tỷ suất sinh lọi của TTCK}

Bảng 4.17 Kết quả hồi quy ngưỡng FD = Tỷ suất sinh lọ̣i của TTCK

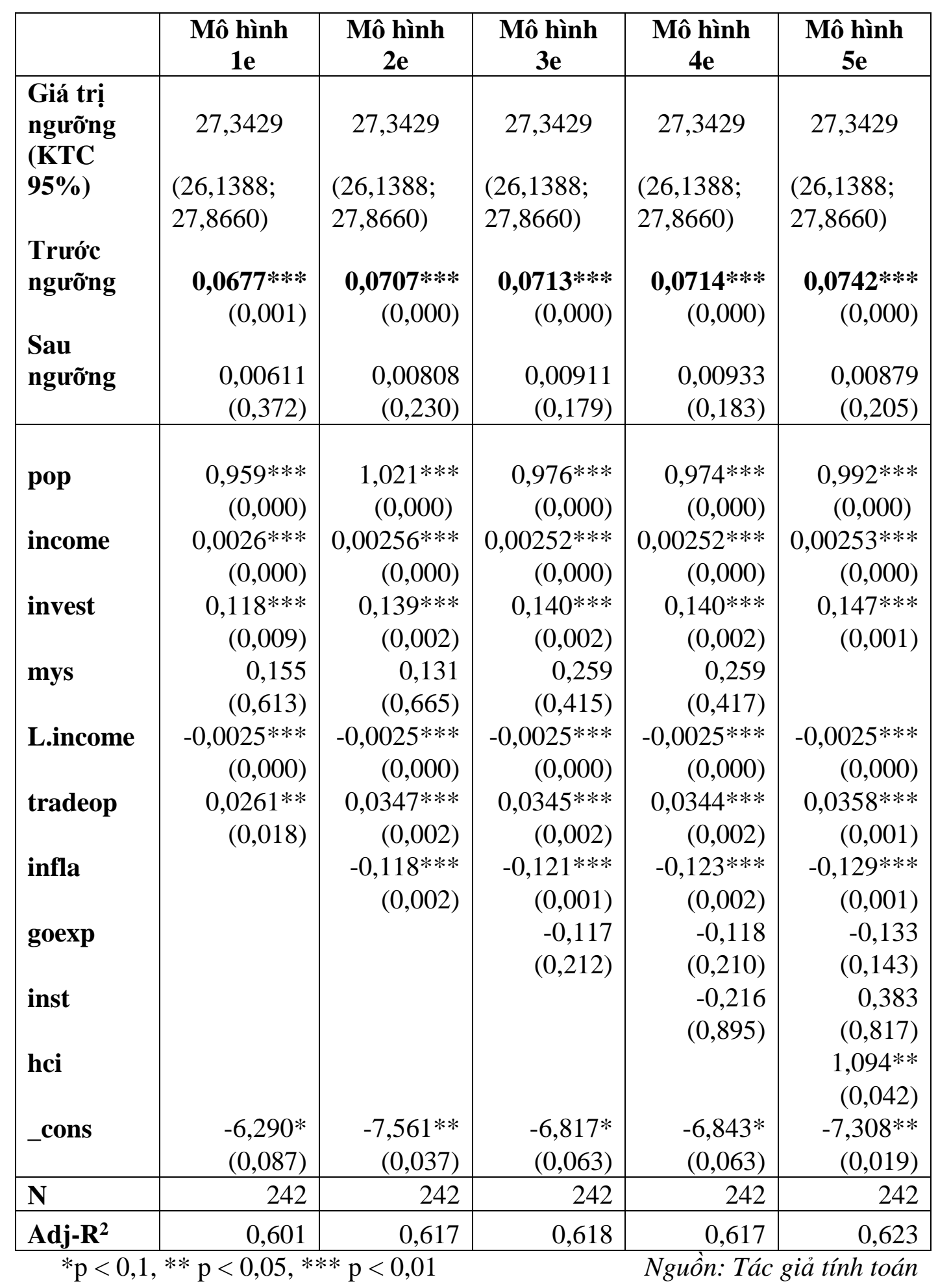


Bảng 4.18 Kiểm định giá trị ngưỡng khi FD = Tỷ suất sinh lọi của TTCK

\begin{tabular}{|c|c|c|c|c|c|c|c|}
\hline \multicolumn{8}{|c|}{ Threshold estimator $($ level $=95)$} \\
\hline $\begin{array}{c}\text { Threshold } \\
27,3429\end{array}$ & Lower & Upper & & & & & \\
\hline \multicolumn{8}{|c|}{ Threshold effect test $($ bootstrap $=20$ ): } \\
\hline $\begin{array}{c}\text { Threshold } \\
\text { Single }\end{array}$ & $\begin{array}{c}\text { RSS } \\
799,8507\end{array}$ & $\begin{array}{l}\text { MSE } \\
3,4626\end{array}$ & $\begin{array}{l}\text { Fstat } \\
14,32\end{array}$ & $\begin{array}{c}\text { Prob } \\
0,1000\end{array}$ & $\begin{array}{c}\text { Crit10 } \\
14,1909\end{array}$ & $\begin{array}{c}\text { Crit5 } \\
17,5012\end{array}$ & $\begin{array}{c}\text { Crit1 } \\
18,2309\end{array}$ \\
\hline
\end{tabular}

Tương tự, tiếp tục thay thế biến FD bằng cách đo lường khác, dùng chỉ tiêu Tỷ suất sinh lợi của TTCK. Kết quả kiểm định về sự tồn tại ngưỡng vẫn cho thấy có giá trị chuyển tiếp và thể hiện sự thay đổi trong tác động của FD khi tỷ suất sinh lợi của TTCK = 27,3429\% đạt ý nghĩa thống kê nhưng đáng tiếc là kết quả trong bảng 4.17 cho thấy tác động của biến FD trước ngưỡng đạt ý nghĩa thống kê với độ tin cậy 99\% nhưng sau ngưỡng thì sự tác động là không thể xác nhận bằng ý nghĩa thống kê được. Tuy vậy, nhìn vào diễn biến thực trạng các nền kinh tế châu Á trong mẫu cũng có thể nhận ra năm 2007 các quốc gia châu Á có TTCK đều tăng trưởng nóng đã vượt xa mức 27,3429\% này và khủng hoảng 2008 diễn ra, tất cả các TTCK đều lao dốc giảm. Như TTCK Việt Nam năm 2007 có tỷ suất sinh lợi là 90,0718\% (nguồn: World Bank) và các chuyên gia tài chính thế giới đã từng cảnh báo về tình trạng vỡ bong bóng chứng khoán TTCK Việt Nam gây tổn thất cho nền kinh tế.

\subsubsection{Quy mô giao dịch của TTCK/GDP}

Bảng 4.19 và 4.20 trình bày kết quả hồi quy khi thay cách đo lường biến $\mathrm{FD}=\mathrm{Quy}$ mô giao dịch của TTCK so với GDP, thể hiện độ sâu trong phát triển tài chính.

\section{Bảng 4.19 Kiểm định giá trị ngưỡng khi FD = Quy mô giao dịch của TTCK /GDP}

$\begin{array}{ccc}\text { Threshold } & \text { Lower } & \text { Upper } \\ 51,2688 & 44,6318 & 52,8341\end{array}$

Threshold effect test $($ bootstrap $=\mathbf{2 0})$ :

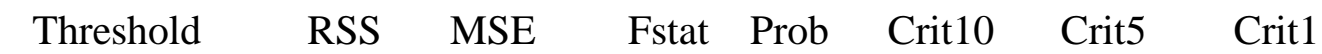

\begin{tabular}{rrrrrrrr} 
Single & 890,7247 & 3,5346 & 19,51 & 0,0000 & 11,7285 & 12,3660 & 13,6395 \\
\hline
\end{tabular} 
Bảng 4.20 Kết quả hồi quy ngưỡng FD = Quy mô giao dịch của TTCK/GDP

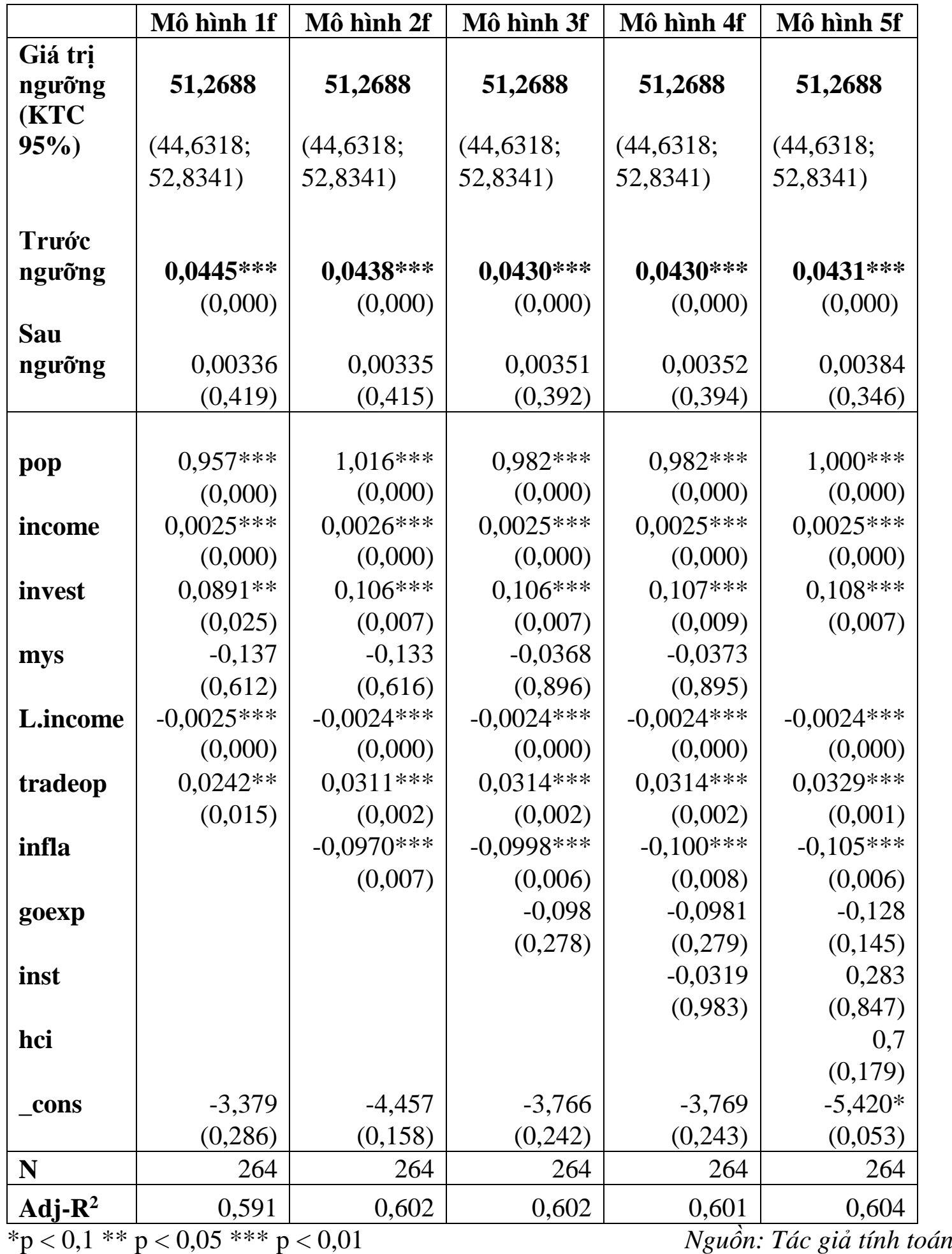


Kiểm định sự tồn tại của ngưỡng có $\mathrm{p}$-value $<0,01 \rightarrow$ bác bỏ Ho cho thấy có tồn tại giá trị ngưỡng của quy mô giao dịch $=51,2688 \%$ so với GDP. Tác động của FD trước giá trị ngưỡng là tích cực, có ý nghĩa thống kê.

Bảng 4.21 Tóm tắt kết quả hồi quy ngưỡng với FD đo bằng dữ liệu TTCK

\begin{tabular}{|c|c|c|c|}
\hline & $\begin{array}{l}\text { Mô hình với } \\
\text { FD= Quy mô vốn } \\
\text { hóa TTCK/GDP }\end{array}$ & $\begin{array}{c}\text { Mô hình với } \\
\text { FD= Tỷ suất sinh } \\
\text { lợi của TTCK }\end{array}$ & $\begin{array}{c}\text { Mô hình với } \\
\text { FD= Quy mô giao } \\
\text { dịchTTCK/GDP }\end{array}$ \\
\hline Giá trị ngưỡng & 81,8477 & 27,3429 & 51,2688 \\
\hline (KTC 95\%) & $(72,4982 ; 81,9182)$ & $(26,1388 ; 27,8660)$ & $(44,6318 ; 52,8341)$ \\
\hline Tác động của FD & & & \\
\hline Trước ngưỡng & $\begin{array}{r}\mathbf{0 , 0 4 5 0} * * * * \\
(0,000)\end{array}$ & $\begin{array}{r}\mathbf{0 , 0 7 0 7} * * * * \\
(0,000)\end{array}$ & $\begin{array}{r}\mathbf{0 , 0 4 3 8} * * * \\
(0,000)\end{array}$ \\
\hline Sau ngưỡng & $\begin{array}{r}\mathbf{0 , 0 2 8 9} * * * \\
(0,000)\end{array}$ & $\begin{array}{r}0,0081 \\
(0,230)\end{array}$ & $\begin{array}{r}0,0034 \\
(0,415)\end{array}$ \\
\hline $\begin{array}{l}\text { Các biến kiểm } \\
\text { soát: }\end{array}$ & & & \\
\hline pop & $\begin{array}{c}1,013 * * * \\
(0,000)\end{array}$ & $\begin{array}{r}1,021 * * * \\
(0,000)\end{array}$ & $\begin{array}{r}1,016^{* * * *} \\
(0,000)\end{array}$ \\
\hline income & $\begin{array}{c}0,0025 * * * \\
(0,000)\end{array}$ & $\begin{array}{r}0,00256 * * * \\
(0,000)\end{array}$ & $\begin{array}{r}0,00255^{* * * *} \\
(0,000)\end{array}$ \\
\hline invest & $\begin{array}{r}0,0756^{*} \\
(0,059)\end{array}$ & $\begin{array}{r}0,139 * * * \\
(0,002)\end{array}$ & $\begin{array}{r}0,106 * * * \\
(0,007)\end{array}$ \\
\hline 1.income & $\begin{array}{c}-0,0024 * * * \\
(0,000)\end{array}$ & $\begin{array}{c}-0,00250 * * * \\
(0,000)\end{array}$ & $\begin{array}{r}-0,00244 * * * \\
(0,000)\end{array}$ \\
\hline tradeop & $\begin{array}{r}0,0278 * * * \\
(0,006)\end{array}$ & $\begin{array}{r}0,0347 * * * \\
(0,002)\end{array}$ & $\begin{array}{r}0,0311 * * * \\
(0,002)\end{array}$ \\
\hline infla & $\begin{array}{r}-0,105 * * * \\
(0,003)\end{array}$ & $\begin{array}{r}-0,118 * * * \\
(0,002)\end{array}$ & $\begin{array}{r}-0,0970 * * * \\
(0,007)\end{array}$ \\
\hline goexp & $\begin{array}{r}-0,153^{*} \\
(0,087)\end{array}$ & & \\
\hline cons & $\begin{array}{r}-2,803 \\
(0,377) \\
\end{array}$ & $\begin{array}{r}-7,561 * * \\
(0,037) \\
\end{array}$ & $\begin{array}{r}-4,457 \\
(0,158) \\
\end{array}$ \\
\hline $\mathrm{N}$ & 264 & 242 & 264 \\
\hline $\operatorname{Adj}-R^{2}$ & 0,613 & 0,617 & 0,602 \\
\hline
\end{tabular}


Bảng 4.22 Tóm tắt giá trị ngưỡng của Phát triển tài chính (market-based)

\begin{tabular}{|l|c|c|c|}
\hline Phát triển tài chính & Ngưỡng & Giá trị thấp nhất & Giá trị cao nhất \\
\hline Quy mô vốn hóa TTCK /GDP & 81,8477 & 72,4982 & 81,9182 \\
\hline Tỷ suất sinh lợi của TTCK & 27,3429 & 26,1388 & 27,8660 \\
\hline Quy mô giao dịch TTCK/GDP & 51,2688 & 44,6318 & 52,8341 \\
\hline
\end{tabular}

Ghi chú: Giá trị cao nhất, thấp nhất được tính toán với độ tin cậy $95 \%$

Nguồn: Tác giả tính toán

Mặc dù hệ số tương quan của biến độc lập là Phát triển tài chính lên biến phụ thuộc là Tăng trưởng kinh tế có đạt ý nghĩa thống kê nhưng hồi quy ngưỡng chỉ thể hiện rằng Phát triển tài chính có tác động thúc đẩy Tăng trưởng kinh tế, dù có vượt qua mức ngưỡng thì vai trò thúc đẩy có bị giảm sút nhưng vẫn là tác động dương chứ không gây cản trở tiêu cực lên tăng trưởng kinh tế.

Khi Phát triển tài chính đo lường thể hiện trên phương diện quy mô vốn hóa thị trường, trong miền $\mathrm{FD}$ < giá trị ngưỡng là $81,8477 \%$ thì thị trường chứng khoán mở rộng thêm $1 \%$ thì thúc đẩy nền kinh tế tăng trưởng $0,045 \%$. Trong miền FD vượt giá trị ngưỡng, thị trường chứng khoán vẫn có tác động tích cực lên tăng trưởng kinh tế nhưng mức tăng của nền kinh tế sụt giảm chỉ còn tăng thêm $0,0289 \%$.

Lý giải cho hiện tượng trên là vì các nước trong mẫu nghiên cứu này là các nền kinh tế mới nổi, thị trường chứng khoán còn trong giai đoạn đầu phát triển, chưa biểu lộ các khiếm khuyết của thị trường nên chỉ mới thể hiện tác động dương đến mức tăng trưởng của nền kinh tế. Mặc dù không thể hiện tác động tiêu cực cản trở tăng trưởng kinh tế nhưng rõ ràng là khi vượt qua ngưỡng, tác động thúc đẩy tăng trưởng kinh tế của Phát triển tài chính giảm đáng kể.

Kết quả được trình bày trong bảng 4.21 cho thấy biến pop, income, invest, tradeop tiếp tục tương quan dương với biến phụ thuộc, đạt ý nghĩa thống kê; riêng biến goexp tương quan âm và chỉ có ý nghĩa thống kê khi FD đo lường bằng quy mô vốn hóa TTCK so với GDP. Mối quan hệ ngược chiều này của biến goexp là sự khác biệt so với các kết quả nghiên cứu trước đây tại các nền kinh tế châu Âu và Mỹ, đó cũng là điểm đặc trưng của các nước châu Á. Nền kinh tế tăng trưởng nhưng chỉ số 
thu nhập của người dân không được cải thiện, các đô thị lớn phát triển kinh tế mạnh mẽ cũng là nơi dân cư đổ dồn về sinh sống, mật độ tập trung dân cư cao, chất lượng cuộc sống không được cải thiện. Tăng trưởng nóng thì các chỉ số phát triển con người lại sụt giảm. Chi tiêu công không hiệu quả gây tổn thất cho nền kinh tế.

\subsubsection{Kết quả ước lượng GMM}

Bảng 4.23 Kết quả GMM trên dữ liệu TTCK

\begin{tabular}{|c|c|c|}
\hline & Mô hình (1) & Mô hình (2) \\
\hline sm_capliz & & $0,0214^{*}$ \\
\hline & & $(0,068)$ \\
\hline $\mathrm{tt} 1$ & & $-0,00188$ \\
\hline & & $(0,812)$ \\
\hline sm_traded & $0,0520 * *$ & \\
\hline $\mathrm{tt} 3$ & $\begin{array}{r}(0,046) \\
-0,0473 *\end{array}$ & \\
\hline & $(0,052)$ & \\
\hline pop & $0,770 * * *$ & $0,814 * * *$ \\
\hline & $(0,000)$ & $(0,000)$ \\
\hline income & $\begin{array}{r}0,00115^{* * * *} \\
(0,000)\end{array}$ & $\begin{array}{r}0,00105^{* * * *} \\
(0,000)\end{array}$ \\
\hline invest & $0,145^{* * *}$ & $0,122 * * *$ \\
\hline & $(0,004)$ & $(0,000)$ \\
\hline tradeop & $-0,00741^{* * * *}$ & $-0,0167 * * *$ \\
\hline & $(0,010)$ & $(0,000)$ \\
\hline infla & $-0,0983 * *$ & $-0,109 * * *$ \\
\hline & $(0,012)$ & $(0,003)$ \\
\hline goexp & $\begin{array}{r}-0,249 * * * \\
(0,000)\end{array}$ & $\begin{array}{r}-0,275^{* * * *} \\
(0,000)\end{array}$ \\
\hline L2. income & $\begin{array}{r}(0,000) \\
-0,00118 * * *\end{array}$ & $-0,00109 * * *$ \\
\hline L2.1mito onte & $(0,000)$ & $(0,000)$ \\
\hline _cons & $3,198 *$ & $4,639^{* * *}$ \\
\hline & $(0,080)$ & $(0,000)$ \\
\hline $\mathrm{N}$ & 242 & 242 \\
\hline p-value & 0,000 & 0,000 \\
\hline $\mathrm{AR}(1)$ & 0,000 & 0,000 \\
\hline $\mathrm{AR}(2)$ & 0,358 & 0,512 \\
\hline Sargan test & 0,514 & 0,191 \\
\hline
\end{tabular}


Cũng tương tự như với dữ liệu ngân hàng, phương pháp ước lượng systemGMM dùng để phân tích thay thế nhằm mục đích củng cố tính vững của kết quả. Mô hình (1) trong bảng 4.23 thể hiện biến FD đo lường bằng Quy mô giao dịch của TTCK so với GDP, mô hình (2) thay thế cách đo lường biến FD bằng tỷ số Quy mô vốn hóa TTCK so với GDP. Phương trình ước lượng GMM khi FD= tỷ suất sinh lợi TTCK không đạt ý nghĩa thống kê nên không được trình bày.

Trước giá trị ngưỡng, bảng 4.23 cho thấy trong hai cách đo lường, hệ số tương quan $\beta_{1}$ của biến FD đều dương và có ý nghĩa thống kê. Trong điều kiện các yếu tố khác không đổi, khi Quy mô giao dịch TTCK tăng $1 \%$ sẽ thúc đẩy nền kinh tế tăng trưởng thêm $0,052 \%$, Quy mô vốn hóa TTCK tăng $1 \%$ sẽ thúc đẩy nền kinh tế tăng trưởng thêm $0,0214 \%$. Các mức tăng nói trên đối với nền kinh tế khá nhỏ nhưng đã phản ánh vai trò tác động tích cực của FD lên tăng trưởng kinh tế. Từ đó làm căn cứ để xây dựng các chiến lược đầu tư phát triển thêm khu vực tài chính.

Sau giá trị ngưỡng, hệ số tác động của biến FD được xác định là $\beta^{*}=\beta_{1}+\beta_{2}$ với $\beta_{1}$ là hệ số tương quan của biến đại diện cho $\mathrm{FD}, \beta_{2}$ là hệ số tương quan của biến tương tác, cụ thể là:

Khi đo lường FD bằng Quy mô giao dịch TTCK: $\beta^{*}=0,0520+(-0,0473)=0,0047$ Khi đo lường FD bằng Quy mô vốn hóa TTCK: $\beta^{*}=0,0214+(-0,00188)=0,0195$

Các kết quả trên cho thấy khi vượt qua giá trị ngưỡng của Phát triển tài chính, sự phát triển của TTCK tại các nước châu Á vẫn giữ vai trò thúc đẩy tăng trưởng kinh tế nhưng mức tăng trưởng có sụt giảm so với trước ngưỡng. Đây cũng là kết luận tìm thấy quan trọng để đề xuất các ý kiến khuyến khích phát triển mở rộng TTCK tại các nước đang phát triển châu Á nhưng cũng cảnh báo với các quốc gia này rằng không nhất thiết cứ tăng trưởng của TTCK là luôn luôn tốt cho nền kinh tế, chỉ nên phát triển đến một mức độ phù hợp.

Trong kết quả từ ước lượng GMM, các kiểm định tự tương quan bậc một $\mathrm{AR}(1)$ có $\mathrm{p}$-value $<\alpha$, kiểm định tự tương quan bậc hai $\mathrm{AR}(2)$ có $\mathrm{p}$-value $>\alpha$ đạt yêu 
cầu. Sargan test có $\mathrm{p}$-value $>\alpha$ cho thấy mô hình không bị yếu bởi nhiều biến công cụ.

Kiểm định giả thuyết Ho: $\left(\beta_{1}+\beta_{2}=0\right)$

Mô hình (1) và (2) đều có p-value $<\alpha$ bác bỏ Ho, tức là hệ số tương quan của biến FD sau ngưỡng $\beta^{*}=\beta_{1}+\beta_{2} \neq 0$ cũng xác nhận sự tồn tại của giá trị ngưỡng tìm được.

\subsection{Phân tích trên mẫu phụ}

\subsubsection{Thống kê mô tả}

Bảng 4.24 Thống kê mô tả mẫu High income

\begin{tabular}{|l|c|c|c|c|c|}
\hline \multicolumn{1}{|c|}{ Biến } & $\mathbf{N}$ & Trung bình & Độ lệch chuẩn & GT thấp nhất & GT cao nhất \\
\hline growth & 260 & 4,733034 & 4,915477 & $-14,15$ & 26,1702 \\
\hline privatecre & 260 & 73,44459 & 40,3876 & 6,9906 & 173,537 \\
\hline domescre & 260 & 88,22039 & 68,25538 & $-10,1518$ & 345,7219 \\
\hline liq & 260 & 78,45646 & 46,83785 & 13,6977 & 217,702 \\
\hline pop & 260 & 2,44817 & 3,045515 & $-0,8638$ & 16,3316 \\
\hline income & 260 & 22207,84 & 18439,77 & 2244,22 & 72670,96 \\
\hline invest & 260 & 27,17612 & 7,661554 & 10,4374 & 47,6859 \\
\hline tradeop & 260 & 108,1681 & 75,58603 & 23,9224 & 441,6038 \\
\hline infla & 260 & 4,643705 & 5,123406 & $-4,8633$ & 39,2664 \\
\hline goexp & 260 & 15,72599 & 4,591623 & 6,733 & 30,0035 \\
\hline inst & 260 & 0,101902 & 0,647972 & $-1,2323$ & 1,5922 \\
\hline mys & 260 & 9,319615 & 2,097498 & 3,4 & 12,8 \\
\hline hci & 260 & 2,745846 & 0,51231 & 1,51 & 3,71 \\
\hline
\end{tabular}

Nguồn: Tác giả tính toán

Mức thu nhập của các nước trong mẫu phụ High income này có giá trị trung bình là 22 207,84 USD/năm, giá trị thấp nhất là 2244,22 USD và giá trị cao nhất lên đến 72670,96 USD/năm. Số năm đi học trung bình (biến mys) có giá trị trung bình là 9,31 năm, giá trị cao nhất là 12,8 năm, Trong mẫu này, chỉ số HDI (biến hci) cũng khá cao. Tuy vậy, điểm số đánh giá về thể chế của mẫu phụ này vẫn không cao, nằm trong khoảng $(-1,2323 ; 1,5922)$ cho thấy tình hình thể chế tại các quốc gia này vẫn tồn tại nhiều vấn đề cần chú ý. 
So sánh số liệu thống kê trong bảng 4.24 và 4.25 cho thấy thu nhập trong hai nhóm nước này khác biệt đáng kể. Trong mẫu phụ tên gọi là nhóm Middle income, các nước này có thu nhập bình quân đầu người trung bình chỉ 1513,948 USD/năm, cao nhất cũng chỉ 3974,732 USD/năm. Điểm đánh giá về thể chế thấp hơn hẳn so với nhóm nước trong mẫu phụ High income, nằm trong khoảng $(-1,7516 ; 0,0603)$ và giá trị trung bình của biến thể chế thậm chí là số âm (-0,7123). Tuy nhiên, về giá trị đầu tư so với GDP (biến invest) của cả hai nhóm nước xấp xỉ ngang bằng nhau.

\section{Bảng 4.25 Thống kê mô tả mẫu Middle income}

\begin{tabular}{|l|c|c|c|c|c|}
\hline \multicolumn{1}{|c|}{ Biến } & Số quan sát & Trung bình & Độ lệch chuẩn & GT thấp nhất & GT cao nhất \\
\hline growth & 169 & 6,368213 & 2,782039 & $-1,2686$ & 17,2908 \\
\hline privatecre & 169 & 35,89574 & 23,3767 & 3,1211 & 123,8149 \\
\hline domescre & 169 & 46,61148 & 25,87915 & 5,5482 & 140,062 \\
\hline liq & 169 & 45,35848 & 24,24075 & 6,7058 & 139,472 \\
\hline pop & 169 & 1,39529 & 0,448215 & 0,5399 & 2,2658 \\
\hline income & 169 & 1513,948 & 960,2453 & 491,6975 & 3974,732 \\
\hline invest & 169 & 28,03799 & 8,358103 & 10,3775 & 58,1507 \\
\hline tradeop & 169 & 73,94407 & 43,02345 & 0,1674 & 184,6863 \\
\hline infla & 169 & 7,929523 & 5,300561 & $-0,6613$ & 35,0246 \\
\hline goexp & 169 & 10,53499 & 3,969252 & 3,4603 & 21,3844 \\
\hline inst & 169 & $-0,71275$ & 0,402197 & $-1,7516$ & 0,0603 \\
\hline mys & 169 & 7,02426 & 2,6365 & 2,7 & 10,9 \\
\hline hci & 169 & 2,273195 & 0,607154 & 0 & 3,34 \\
\hline
\end{tabular}

Nguồn: Tác giả tính toán

Nhóm High income cho thấy việc kiểm soát lạm phát tốt hơn so với nhóm Middle income, lạm phát trung bình của các nước trong giai đoạn nghiên cứu là $4,64 \%$ trong khi đối với nhóm Middle income, lạm phát trung bình gần như cao gấp đôi lên đến 7,93\%. Các chỉ số đánh giá về nguồn vốn con người (biến mys và biến hci) trong nhóm Middle income thấp hơn so với nhóm High income. Về tình hình phát triển tài chính, nhóm High income có cả ba chỉ tiêu đều cao gần như gấp đôi so với nhóm Middle income, phản ánh thực tế là các nước trong nhóm Middle income có hệ thống tài chính chưa phát triển mạnh như các nước trong nhóm High income. Theo một số ít các tài liệu nghiên cứu trước, tác động đổi chiều của phát triển tài chính lên tăng trưởng kinh tế đối với các nước đang phát triển thể hiện mức ý nghĩa 
thống kê yếu (Law và Singh, 2014) nhưng vai trò thúc đẩy tăng trưởng kinh tế của phát triển tài chính đối với nhóm nước đang phát triển lại mạnh mẽ hơn so với các nước phát triển (Rioja và Valev, 2004b). Phần tiếp theo của luận án trình bày kết quả hồi quy ngưỡng trong từng mẫu phụ để kiểm nghiệm các kết luận tìm thấy trong toàn mẫu đã được đề cập ở phần trên có khác biệt gì không khi bối cảnh các nước nghiên cứu khác biệt nhau về thu nhập.

\subsubsection{Phân tích mẫu phụ High income}

Bảng 4.26 Kết quả hồi quy ngưỡng mẫu phụ High income

\begin{tabular}{|c|c|c|c|}
\hline & $\begin{array}{c}\text { FD=Tín dụng tư } \\
\text { nhân/GDP }\end{array}$ & $\begin{array}{l}\text { FD=Tín dụng } \\
\text { trong nước/GDP }\end{array}$ & $\begin{array}{c}\text { FD }=\text { cung tiền } \\
\text { M3/GDP }\end{array}$ \\
\hline Giá trị ngưỡng & 13,5779 & 35,8534 & 36,8089 \\
\hline \multirow[t]{2}{*}{ Trước ngưỡng } & $1,021 * * *$ & $0,100 * * *$ & $0,106^{* *}$ \\
\hline & $(0,001)$ & $(0,003)$ & $(0,019)$ \\
\hline \multirow[t]{2}{*}{ Sau ngưỡng } & $-0,00841$ & $-0,0174$ & $-0,0496 *$ \\
\hline & $(0,691)$ & $(0,301)$ & $(0,077)$ \\
\hline \multirow[t]{2}{*}{ pop } & $0,948 * * *$ & $0,888 * * *$ & $0,871 * * *$ \\
\hline & $(0,000)$ & $(0,000)$ & $(0,000)$ \\
\hline \multirow[t]{2}{*}{ income } & $0,00265 * * *$ & $0,00263 * * *$ & $0,00252 * * *$ \\
\hline & $(0,000)$ & $(0,000)$ & $(0,000)$ \\
\hline \multirow[t]{2}{*}{ invest } & $0,110 * *$ & $0,0963 *$ & $0,175 * * *$ \\
\hline & $(0,042)$ & $(0,069)$ & $(0,001)$ \\
\hline \multirow[t]{2}{*}{ mys } & $-0,104$ & $-0,108$ & 0,536 \\
\hline & $(0,829)$ & $(0,843)$ & $(0,295)$ \\
\hline \multirow[t]{2}{*}{ L.income } & $-0,00260 * * *$ & $-0,00256 * * *$ & $-0,00248 * * *$ \\
\hline & $(0,000)$ & $(0,000)$ & $(0,000)$ \\
\hline \multirow[t]{2}{*}{ tradeop } & 0,0223 & $0,0256^{*}$ & 0,0216 \\
\hline & $(0,150)$ & $(0,096)$ & $(0,160)$ \\
\hline \multirow[t]{2}{*}{ infla } & $-0,102$ & $-0,154 * *$ & $-0,187 * * *$ \\
\hline & $(0,141)$ & $(0,020)$ & $(0,006)$ \\
\hline \multirow[t]{2}{*}{ goexp } & $-0,279 *$ & $-0,322 * *$ & $-0,299 * *$ \\
\hline & $(0,060)$ & $(0,016)$ & $(0,044)$ \\
\hline \multirow[t]{2}{*}{ inst } & $-1,107$ & 1,065 & $-1,438$ \\
\hline & $(0,621)$ & $(0,638)$ & $(0,514)$ \\
\hline \multirow[t]{2}{*}{ _cons } & 1,794 & 2,860 & $-1,895$ \\
\hline & $(0,737)$ & $(0,615)$ & $(0,720)$ \\
\hline $\mathrm{N}$ & 240 & 220 & 240 \\
\hline $\operatorname{Adj}-R^{2}$ & 0,501 & 0,546 & 0,525 \\
\hline
\end{tabular}


Kết quả trên mẫu phụ High income cho thấy những kết luận tương đồng với những gì tìm thấy trong toàn mẫu.

Dân số (biến pop), đầu tư (biến invest), thu nhập bình quân đầu người trong kỳ (biến income) vẫn thể hiện tác động dương lên tăng trưởng kinh tế có ý nghĩa thống kê. Dân số tăng tại các quốc gia châu Á vừa kéo theo nhu cầu tiêu dùng sản phẩm dịch vụ tăng lên, vừa tạo ra nguồn lao động dồi dào với chi phí không cao đã tạo ra tính cạnh tranh đáng kể cho thị trường lao động của các nền kinh tế này, thu hút vốn đầu tư, kích thích sản xuất, dẫn đến thúc đẩy tăng trưởng kinh tế. Nhiều nước trong mẫu phụ High income là các nền kinh tế phát triển mạnh như Nhật Bản, Hàn Quốc, Singapore, ...thì nhân tố thu nhập - thể hiện qua chỉ tiêu GDP bình quân đầu người cao - góp phần giúp tích lũy vốn, đầu tư xây dựng cơ sở hạ tầng, đầu tư cho nghiên cứu cải tiến, đổi mới sáng tạo nhằm nâng cao năng suất lao động, thúc đẩy tăng trưởng kinh tế. Do đó, thu nhập thể hiện tương quan dương với tăng trưởng kinh tế, giống như kỳ vọng nghiên cứu và tương đồng với kết quả của Rioja và Valev (2004b).

Tuy nhiên tự do hóa thương mại (biến tradeop) mặc dù vẫn thể hiện tác động tích cực nhưng chỉ đạt ý nghĩa thống kê khi FD đo lường bằng tín dụng trong nước

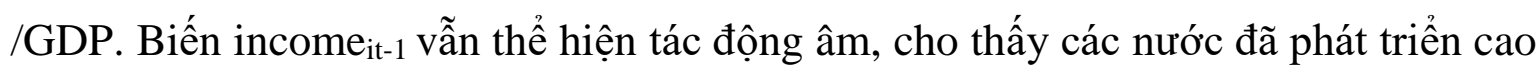
thì tăng trưởng kinh tế có chậm lại hơn so với các nước đang phát triển. 
Bảng 4.27 Kiểm định sự tồn tại của ngưỡng trong mẫu phụ High income

\begin{tabular}{|c|c|c|c|c|c|c|c|c|}
\hline \multirow{6}{*}{ 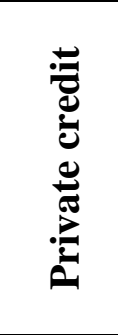 } & \multicolumn{8}{|c|}{ Threshold estimator $($ level $=95)$} \\
\hline & Threshold & Lower & Upper & & & & & \\
\hline & 13,5779 & 8,8375 & 19,3867 & & & & & \\
\hline & \multicolumn{8}{|c|}{ Threshold effect test $($ bootstrap $=20)$ : } \\
\hline & Threshold & RSS & MSE & Fstat & Prob & Crit10 & Crit5 & Crit1 \\
\hline & Single & 1830,13 & 8,0269 & 24,12 & 0,000 & 10,483 & 15,2103 & 16,6476 \\
\hline \multirow{6}{*}{ 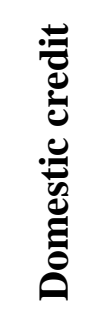 } & \multicolumn{8}{|c|}{ Threshold estimator $($ level $=95)$} \\
\hline & Threshold & Lower & Upper & & & & & \\
\hline & 35,8534 & 29,8897 & 36,0609 & & & & & \\
\hline & \multicolumn{8}{|c|}{ Threshold effect test (bootstrap $=30$ ): } \\
\hline & Threshold & RSS & MSE & Fstat & Prob & Crit10 & Crit5 & Crit1 \\
\hline & Single & 1470,186 & 7,0344 & 17,83 & 0,033 & 15,8896 & 16,7005 & 25,2471 \\
\hline \multirow{6}{*}{ } & \multicolumn{8}{|c|}{ Threshold estimator $($ level $=95)$} \\
\hline & Threshold & Lower & Upper & & & & & \\
\hline & 36,8089 & 34,5261 & 36,9266 & & & & & \\
\hline & \multicolumn{8}{|c|}{ Threshold effect test $($ bootstrap $=30)$ : } \\
\hline & Threshold & RSS & MSE & Fstat & Prob & Crit10 & Crit5 & Crit1 \\
\hline & Single & 1773,035 & 7,7765 & 29,00 & 0,000 & 18,9779 & 22,2493 & 22,8804 \\
\hline
\end{tabular}

Kết quả kiểm định trình bày trong bảng 4.27 cho thấy $\mathrm{p}$-value $<\alpha$ chứng tỏ tồn tại giá trị ngưỡng, và có một giá trị ngưỡng.

\subsubsection{Phân tích mẫu phụ Middle income}

Tương tự kết quả trên mẫu phụ High income, mẫu phụ thứ hai Middle income này, kết quả kiểm định ngưỡng cho thấy p-value $<\alpha$ chứng tỏ tồn tại giá trị ngưỡng, và có một giá trị ngưỡng.

So sánh kết quả trong các bảng cho thấy: Các kết quả tìm thấy trong hai mẫu phụ đều nhất quán với kết quả trong toàn mẫu và cho thấy tồn tại mối quan hệ phi tuyến và giá trị ngưỡng của phát triển tài chính. Hệ số tương quan của biến FD đo theo cả ba cách đều chứng tỏ phát triển tài chính vẫn thể hiện tác động đổi chiều từ dương sang âm khi biến FD vượt qua giá trị ngưỡng. Điều này cho thấy các kết luận tìm thấy của nghiên cứu đáng tin cậy. 
Bảng 4.28 Kết quả hồi quy ngưỡng mẫu phụ Middle income

\begin{tabular}{|c|c|c|c|}
\hline & Mô hình 1 & Mô hình 2 & Mô hình 3 \\
\hline & $\begin{array}{c}\text { FD=Tín dụng tư } \\
\text { nhân/GDP }\end{array}$ & $\begin{array}{l}\text { FD=Tín dụng } \\
\text { trong nước/GDP }\end{array}$ & $\begin{array}{c}\text { FD= cung tiền } \\
\text { M3/GDP }\end{array}$ \\
\hline Giá trị ngưỡng & 6,3511 & 7,2236 & 20,1052 \\
\hline Trước ngưỡng & $\begin{array}{r}0,774 * * * \\
(0,000)\end{array}$ & $\begin{array}{r}0,612 * * \\
(0,013)\end{array}$ & $\begin{array}{r}0,198 * * * \\
(0,000)\end{array}$ \\
\hline Sau ngưỡng & $\begin{array}{r}-0,0237 * * \\
(0,046) \\
\end{array}$ & $\begin{array}{r}-0,00515 \\
(0,675) \\
\end{array}$ & $\begin{array}{r}-0,0307 * * \\
(0,022) \\
\end{array}$ \\
\hline pop & $\begin{array}{r}1,992 * * * \\
(0,002)\end{array}$ & $\begin{array}{r}1,893 * * * \\
(0,007)\end{array}$ & $\begin{array}{r}1,349 * * \\
(0,027)\end{array}$ \\
\hline income & $\begin{array}{r}0,0427 * * * \\
(0,000)\end{array}$ & $\begin{array}{r}0,0448 * * * \\
(0,000)\end{array}$ & $\begin{array}{r}0,0428 * * * \\
(0,000)\end{array}$ \\
\hline invest & $\begin{array}{r}-0,0516^{*} \\
(0,055)\end{array}$ & $\begin{array}{r}-0,0832 * * * \\
(0,004)\end{array}$ & $\begin{array}{r}-0,0492^{*} \\
(0,062)\end{array}$ \\
\hline mys & $\begin{array}{r}-0,237 \\
(0,354)\end{array}$ & $\begin{array}{r}-0,428 \\
(0,114)\end{array}$ & $\begin{array}{r}-0,109 \\
(0,670)\end{array}$ \\
\hline L.income & $\begin{array}{r}-0,0445^{* * * *} \\
(0,000)\end{array}$ & $\begin{array}{r}-0,0468 * * * \\
(0,000)\end{array}$ & $\begin{array}{r}-0,0444 * * * \\
(0,000)\end{array}$ \\
\hline tradeop & $\begin{array}{r}0,010 \\
(0,311)\end{array}$ & $\begin{array}{r}-0,00302 \\
(0,777)\end{array}$ & $\begin{array}{r}0,0192 * \\
(0,058)\end{array}$ \\
\hline infla & $\begin{array}{r}0,0386 * \\
(0,062)\end{array}$ & $\begin{array}{r}0,0493 * * \\
(0,027)\end{array}$ & $\begin{array}{l}0,0136 \\
(0,508)\end{array}$ \\
\hline goexp & $\begin{array}{r}-0,0686 \\
(0,304)\end{array}$ & $\begin{array}{r}-0,127 * \\
(0,076)\end{array}$ & $\begin{array}{r}-0,0886 \\
(0,168)\end{array}$ \\
\hline inst & $\begin{array}{r}3,223 * * * \\
(0,007)\end{array}$ & $\begin{array}{c}2,073 * \\
(0,097)\end{array}$ & $\begin{array}{r}2,611 * * \\
(0,023)\end{array}$ \\
\hline _cons & $\begin{array}{r}8,936 * * * \\
(0,001) \\
\end{array}$ & $\begin{array}{r}11,62 * * * \\
0,000 \\
\end{array}$ & $\begin{array}{r}8,233 * * * \\
(0,001) \\
\end{array}$ \\
\hline $\mathrm{N}$ & 156 & 156 & 156 \\
\hline Adj-R ${ }^{2}$ & 0,756 & 0,716 & 0,770 \\
\hline
\end{tabular}

Đối với nhóm Middle income, khi Tín dụng dành cho khu vực tư nhân không quá 6,3511\% so với GDP, Tín dụng trong nước không vượt mức 7,2236\% so với GDP, và cung tiền không vượt quá $17,0942 \%$ so với GDP thì phát triển tài chính thể 
hiện tác động tích cực. Giá trị của ngưỡng thấp có thể được giải thích là bởi vì hệ thống tài chính nói chung và hệ thống ngân hàng tại các quốc gia thuộc nhóm Middle income hoạt động chưa thực sự tốt và hiệu quả để có thể làm nhân tố thúc đẩy mạnh mẽ cho tăng trưởng kinh tế. Tính dễ tổn thương của hệ thống ngân hàng khiến cho giá trị ngưỡng tối ưu không cao. Chỉ cần cung tiền mở rộng M3 vượt hơn 17,0942\% so với GDP hay là Tín dụng dành cho khu vực tư nhân vượt 6,3511\% so với GDP thì nền kinh tế có thể bị cản trở tăng trưởng. Kết quả này cũng hàm ý rằng cần cải thiện về tính hiệu quả của chính sách tiền tệ và việc quản lý hoạt động của hệ thống ngân hàng tại các quốc gia này.

Bảng 4.29 Kiểm định sự tồn tại của ngưỡng trong mẫu phụ Middle income

\begin{tabular}{|c|c|c|c|c|c|c|c|c|}
\hline \multirow{6}{*}{ 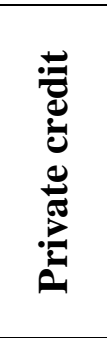 } & \multicolumn{8}{|c|}{ Threshold estimator $($ level $=95)$} \\
\hline & Threshold & Lower & Upper & & & & & \\
\hline & 6,3511 & 4,3221 & 6,7468 & & & & & \\
\hline & \multicolumn{8}{|c|}{ Threshold effect test $($ bootstrap $=20)$ : } \\
\hline & Threshold & RSS & MSE & Fstat & Prob & Crit10 & Crit5 & Crit1 \\
\hline & Single & 172,5078 & 1,198 & 30,39 & 0,0000 & 16,832 & 17,8211 & 18,2373 \\
\hline \multirow{6}{*}{ 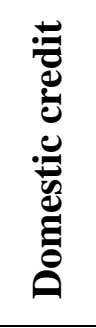 } & \multicolumn{8}{|c|}{ Threshold estimator $($ level = 95) } \\
\hline & Threshold & Lower & Upper & & & & & \\
\hline & 7,2236 & 5,5482 & 8,2506 & & & & & \\
\hline & \multicolumn{8}{|c|}{ Threshold effect test $($ bootstrap $=20$ ): } \\
\hline & Threshold & RSS & MSE & Fstat & Prob & Crit10 & Crit5 & Crit1 \\
\hline & Single & 183,0932 & 1,2715 & 21,5 & 0,0500 & 18,3396 & 18,5883 & 22,7617 \\
\hline \multirow{6}{*}{ } & \multicolumn{8}{|c|}{ Threshold estimator $($ level = 95) } \\
\hline & Threshold & Lower & Upper & & & & & \\
\hline & 20,1052 & 17,8614 & 20,1891 & & & & & \\
\hline & \multicolumn{8}{|c|}{ Threshold effect test $($ bootstrap $=20)$ : } \\
\hline & Threshold & RSS & MSE & Fstat & Prob & Crit10 & Crit5 & Crit1 \\
\hline & Single & 160,6283 & 1,1155 & 39,45 & 0,0000 & 13,4204 & 14,3753 & 19,7846 \\
\hline
\end{tabular}

Nguồn: Tác giả tính toán

Có sự khác biệt giữa tham số ngưỡng của hai nhóm nước. Đối với nhóm High income, các giá trị ngưỡng của các chỉ tiêu đo lường FD đều cao hơn so với nhóm Middle income. 
Bảng 4.30 Ngưỡng của Phát triển tài chính trong mẫu phụ và toàn mẫu

\begin{tabular}{|c|l|c|c|c|c|}
\hline \multicolumn{2}{|l|}{ Financial Development } & Ngươnng & Thấp nhất & Cao nhất & P-value \\
\hline \multirow{4}{*}{$\begin{array}{c}\text { Private } \\
\text { credit }\end{array}$} & Full sample & 8,9762 & 8,4427 & 9,3103 & 0,0400 \\
\cline { 2 - 6 } & High income & 13,5779 & 8,8375 & 19,3867 & 0,0000 \\
\cline { 2 - 6 } & Middle income & 6,3511 & 4,2671 & 6,3511 & 0,0000 \\
\hline \multirow{4}{*}{$\begin{array}{c}\text { Domestic } \\
\text { credit }\end{array}$} & Full sample & 8,8641 & 8,1817 & 9,2651 & 0,0667 \\
\cline { 2 - 6 } & High income & 35,8534 & 29,8897 & 36,0609 & 0,0333 \\
\cline { 2 - 6 } $\begin{array}{c}\text { Liquid } \\
\text { Liabilities }\end{array}$ & Middle income & 7,2236 & 5,5482 & 7,6371 & 0,0500 \\
\cline { 2 - 6 } & High income & 18,4802 & 17,9976 & 19,6984 & 0,0200 \\
\hline
\end{tabular}

Ghi chú: Giá trị cao nhất, thâp nhất được tính toán với độ tin cậy $95 \%$

Nguồn: Tác giả tính toán

Xem xét thực trạng các nước trong nhóm High income thấy rằng cả ba chỉ tiêu phản ánh FD đều cao gần như gấp đôi so với nhóm Middle income, cho thấy hệ thống tài chính của các nước trong nhóm này đã có trình độ phát triển cao, dẫn đến mức ngưỡng tìm thấy cho FD của nhóm này cao trội so với nhóm Middle income. Law và Singh (2014) khẳng định tham số ngTóm lại kết quả của luận án này cho thấy không phải luôn luôn trong mọi bối cảnh, hệ thống tài chính tốt thì nền kinh tế tăng trưởng. Giai đoạn nghiên cứu của luận án này bao gồm năm 2008, 2009 cũng là khoảng thời gian các nền kinh tế châu Á chịu ảnh hưởng nặng nề từ khủng hoảng. Trước khủng hoảng 2008, nhiều chuyên gia nhận định châu Á tăng trưởng vượt bậc chính là nhờ mở cửa thương mại và phát triển hệ thống tài chính mạnh mẽ, vượt ra khỏi biên giới quốc gia phát triển mạnh mẽ trên toàn cầu. Tuy nhiên thực tiễn sau khủng hoảng 2008 cho thấy các nước châu Á cũng đã phải thực hiện cải tổ rất nhiều hệ thống ngân hàng của mình, chứng tỏ chiến lược đẩy mạnh phát triển rộng hệ thống tài chính của họ không còn phù hợp để duy trì tốc độ tăng trưởng kinh tế. Phân tích hồi quy ngưỡng không thể thực hiện được với dữ liệu dựa trên thị trường (TTCK) chia theo subsample vì số quan sát trong mẫu không đủ để tiến hành. Đây cũng là hướng nghiên cứu trong tương lai của luận án là thu thập mẫu lớn hơn và dữ liệu có độ dài thời gian nhiều hơn. 


\section{Kết luận chương 4}

Tóm lại, phân tích trong toàn mẫu cũng như trong hai mẫu phụ cho thấy các kết luận sau đây:

$\checkmark$ Có sụ khác biệt giữa tham số nguõng của hai nhóm nuớc thu nhập cao và thu thập trung bình nhưng các kết luận trong toàn mẫu nhất quán với kết luận trong hai mẫu phụ. Điều này cho thấy các kết luận tìm thấy đáng tin cậy và nhất quán cho các quốc gia châu Á trong mẫu nghiên cứu này.

$\checkmark$ Phát triển tài chính có vai trò thúc đẩy tăng trương kinh tế khi giá trị của nó chua vuợt mức nguõng giới hạn

$\checkmark$ Khi Phát triển tài chính vuợt qua giá trị nguoơng thì nó lại gây ra tác động kìm hãm đối với Tăng truởng kinh tế. Mặc dù vậy, tác động tích cực thì có hệ số tuoong quan lớn hơn đáng kể so với tác động tiêu cực, hàm ý rằng trong dài hạn Phát triển tài chính vẫn giữ vai trò là nhân tố quan trọng trong việc làm gia tăng mức sản lương của nền kinh tế, miễn là đừng phát triển hệ thống tài chính quá mức.

Kết quả thực nghiệm trên toàn mẫu đã trả lời cho câu hỏi nghiên cứu và xác nhận giả thuyết nghiên cứu $\mathrm{H}_{1}$, đó là mối quan hệ giữa phát triển tài chính và tăng trưởng của nền kinh tế không phải là tuyến tính, mà xuất hiện giá trị thể hiện sự chuyển tiếp của tác động, gọi là mức ngưỡng của phát triển tài chính. Giá trị ngưỡng của tín dụng dành cho khu vực tư nhân là 8,9762\% so với GDP; tín dụng trong nước là $8,8641 \%$ so với GDP; và cung tiền mở rộng M3 là 18,0957\% so với GDP. Giá trị ngưỡng của quy mô vốn hóa TTCK tại các nước châu Á là $81,8477 \%$ so với GDP; tỷ suất sinh lợi của TTCK là 27,3429\%; và quy mô giao dịch là $51,2688 \%$ so với GDP.

Câu hỏi nghiên cứu thứ hai, thứ ba và giả thuyết $\mathrm{H}_{2}, \mathrm{H}_{3}$ cũng được xác nhận bằng thực nghiệm rằng đối với dữ liệu của khu vực ngân hàng, kết quả nghiên cứu đều đạt ý nghĩa thống kê và cho thấy rằng: trong miền giá trị dưới ngưỡng, phát triển tài chính thể hiện vai trò thúc đẩy cho tăng trưởng kinh tế, tác động là tích cực; tuy nhiên trong miền giá trị mà phát triển tài chính vượt trên mức ngưỡng, nó lại thể hiện 
tác động tiêu cực. Tuy nhiên, khi phản ánh mức độ phát triển của thị trường tài chính thông qua các chỉ tiêu về TTCK thì trong miền giá trị dưới ngưỡng, phát triển tài chính thể hiện tác động dương; vượt trên mức ngưỡng, nó vẫn tiếp tục thể hiện tác động dương nhưng mức độ thúc đẩy cho nền kinh tế tăng trưởng bị sụt giảm

Từ những kết quả thực nghiệm này, trong chương tiếp theo luận án đề xuất các ý kiến và giải pháp cho phát triển tài chính nhằm hướng tới tăng trưởng kinh tế để trả lời cho câu hỏi nghiên cứu thứ ba là cần làm gì để hướng tới tăng trưởng trong dài hạn. 


\section{CHUO'NG 5}

\section{GIẢI PHÁP VÀ Ý KIẾN ĐỀ XUẤT PHÁT TRIỂN TÀI CHÍNH ĐỂ TĂNG TRƯỞNG KINH TẾ TẠI CÁC NƯớC CHÂU Á}

Khủng hoảng toàn cầu 2008 đã gợi lên những câu hỏi chính đáng về mức độ phát triển sâu và rộng của hệ thống tài chính như thế nào cho hiệu quả và thúc đẩy chứ không kìm hãm nền kinh tế tăng trưởng. Các nền kinh tế thế giới đã phạm sai lầm gì và bài học nào từ cuộc khủng hoảng này cho các thị trường mới nổi châu Á. Cuộc khủng hoảng này được cho rằng xuất phát chính từ các nền kinh tế đã phát triển cao, nơi mà ngành tài chính đã phát triển vừa rộng lớn vừa phức tạp. Từ thực tiễn cuộc khủng hoảng này mà các nhà nghiên cứu kinh tế cũng như các nhà hoạch định chính sách đã phải cân nhắc, xem xét lại: liệu có phải tồn tại một mức ngưỡng giới hạn cho phát triển tài chính để nó có thể thúc đẩy tăng trưởng kinh tế và duy trì sự ổn định hay không; mức độ phát triển hợp lý của khu vực tài chính là bao nhiêu; vai trò của thể chế chính trị giúp thúc đẩy phát triển một hệ thống tài chính an toàn như thế nào; các nền kinh tế mới nổi châu Á có học hỏi được bài học kinh nghiệm nào từ kinh nghiệm của các nền kinh tế đã phát triển cao làm sao để phát huy và tận dụng được các lợi ích mà phát triển tài chính đem lại cho nền kinh tế trong khi có thể tránh những cạm bẫy nguy hiểm của việc phát triển quá đà của hệ thống tài chính.

Kết quả thực nghiệm của nghiên cứu này đã trả lời được cho ba câu hỏi nghiên cứu đã đặt ra, đó là tìm thấy rằng tồn tại một mức ngưỡng cho phát triển tài chính. Trong miền giá trị dưới mức ngưỡng này, phát triển tài chính có vai trò tích cực, thúc đẩy tăng trưởng kinh tế. Tuy nhiên nếu phát triển tài chính vượt quá mức ngưỡng thì phát triển tài chính lại gây ra tác động phá hủy, gây kìm hãm và làm giảm tăng trưởng kinh tế. Vì vậy, vấn đề ở đây là phát triển hệ thống tài chính tại các quốc gia đang phát triển châu Á không phải là hoạt động mở rộng hệ thống ngân hàng hay thị trường 
chứng khoán mà các giải pháp cần tập trung hướng đến khai thác tính hiệu quả và vai trò tích cực của việc phát triển tài chính. Có như vậy trong dài hạn mới hướng đến mục tiêu mà các nước này đang theo đuổi là tăng trưởng nền kinh tế bền vững, giảm khoảng cách với các quốc gia đã phát triển trên thế giới. Từ kết quả nghiên cứu, luận án đề xuất một số ý kiến và giải pháp liên quan đến phát triển tài chính để duy trì tăng trưởng kinh tế trong dài hạn như sau:

\subsection{Cơ cấu phát triển và cách thức quản lý hệ thống tài chính cần linh hoạt, tăng khả năng cạnh tranh}

Hermes và Lenskink (2000) đã lập luận rằng đóng góp tích cực mà hệ thống tài chính có thể thực hiện đối với quá trình phát triển kinh tế phụ thuộc vào việc thiết kế và vận hành hệ thống tài chính. Vì vậy, việc chọn lựa cơ cấu để phát triển hệ thống tài chính cần đảm bảo nguyên tắc linh hoạt, tôn trọng thị trường.

Thực trạng hiện tại của các nước châu Á đang phát triển, trong đó có Việt Nam, việc cung ứng vốn cho nền kinh tế chủ yếu phụ thuộc vào hệ thống ngân hàng. Mặc dù còn một số ít quốc gia chưa hình thành thị trường chứng khoán do tình hình còn lạc hậu và nền kinh tế chưa đủ tiềm lực như Myanmar, Cambodia, Taijikistan hay do điều kiện đặc biệt về địa lý và tài nguyên thiên nhiên như Brunei, Maldives thì hầu hết các nước châu Á đều có thị trường tiền tệ, thị trường ngoại hối, thị trường chứng khoán (bao gồm cả chứng khoán phái sinh) và thị trường trái phiếu. Tuy nhiên, các thị trường này phát triển không đồng đều, không tạo nên một môi trường cạnh tranh thực sự về vốn. Thí dụ như ở Việt Nam tính đến 2016, tổng giá trị vốn hoá của thị trường cổ phiếu đã lên tới 40\% GDP, trong khi của thị trường trái phiếu doanh nghiệp mới ở mức 4\%. Mức độ tự do hoá tài khoản vốn thấp, sản phẩm đơn giản, thiếu sự góp mặt của các sản phẩm phái sinh phổ biến cũng làm giảm hiệu quả và khiến thị trường không thu hút được sự quan tâm của các nhà đầu tư nước ngoài.

Kết quả nghiên cứu của luận án này đã chỉ ra rằng mức ngưỡng tối ưu đối với phát triển tài chính ở các nước châu Á không phải là các giá trị cao, như mức tối ưu của Tín dụng dành cho khu vực tư nhân là 8,9762\% so với GDP, Tín dụng trong nước 
là 8,8641\% so với GDP, và cung tiền mở rộng M3 chỉ nên là 18,0957\% so với GDP. Đặc biệt là những nước châu Á thuộc nhóm thu nhập trung bình thấp, do nguồn cung ứng vốn chủ lực là chỉ từ hệ thống ngân hàng, tính dễ tổn thương của hệ thống ngân hàng tại các nước này khiến cho giá trị ngưỡng tối ưu không cao. Vì thế việc các nước này cần làm trong chiến lược phát triển hệ thống tài chính của họ không phải là bành trướng, mở rộng về quy mô hay số lượng mà phải tập trung hướng đến phát triển tài chính theo chiều sâu, tăng hiệu quả và tăng giá trị mới là mục đích hướng đến. Cách thức tổ chức và quản lý hệ thống tài chính cần đảm bảo nguyên tắc tôn trọng quan hệ thị trường, tăng tính cạnh tranh và linh hoạt thì mới thu hút được các nhà đầu tư cung ứng vốn trong và ngoài nước. Kết quả này cũng hàm ý rằng cần cải thiện về tính hiệu quả của chính sách tiền tệ và việc quản lý hoạt động của hệ thống ngân hàng tại các quốc gia này.

Các giải pháp cụ thể để phát triển tài chính đảm bảo các yêu cầu nêu trên như sau:

- Cải thiện thể chế và tổ chức trong hệ thống tài chính

- Quy định và luật pháp liên quan đến hoạt động của toàn bộ hệ thống tài chính cần chặt chẽ, rõ ràng để thực thi, đảm bảo việc giám sát chặt chẽ để làm giảm bất cân xứng thông tin, tăng sự hoàn thiện của thị trường.

- Trao quyền hợp lý để tăng khả năng cho các tổ chức tham gia vào các giao dịch tài chính bằng hợp đồng, giảm chi phí giao dịch, tăng sự cạnh tranh.

- Cải tiến, đổi mới sản phẩm tài chính, nâng cao năng lực của các chủ thể và tổ chức trong hệ thống tài chính.

Các giải pháp nói trên không rời rạc mà nằm trong một tổng thể quá trình cải thiện về số lượng, chất lượng và hiệu quả của dịch vụ, trung gian tài chính, liên quan đến sự hoạt động và tương tác của nhiều tổ chức, cá nhân khác nhau trên thị trường tài chính. 


\subsection{Minh bạch thông tin trong hoạt động của hệ thống tài chính}

Sự phát triển tài chính là khả năng của một quốc gia chuyển từ kênh tiết kiệm sang kênh đầu tư một cách hiệu quả thông qua quy mô của thị trường tài chính, sự đa dạng của các công cụ tài chính, mức độ dễ dàng trong việc tiếp cận các nhà đầu tư cá nhân. Thị trường tài chính hoạt động tốt thể hiện qua tính hiệu quả và tính thanh khoản trên thị trường (Dorruci và cộng sự, 2009). Trong khi đó, vấn đề tồn tại trong thời gian dài và là rào cản thị trường tài chính tại các nước đang phát triển châu Á chính là bất cân xứng thông tin, vốn dĩ luôn tồn tại trong quá trình huy động và sử dụng vốn. Vì vậy, đảm bảo minh bạch thông tin trong hoạt động của hệ thống tài chính cần là mục tiêu hàng đầu trong việc xây dựng các chiến lược hoạt động, xây dựng hành lang pháp lý, quy chế và quy định cho hoạt động của hệ thống ngân hàng và các định chế tài chính trung gian khác, cho hoạt động giao dịch trên các thị trường vốn và thị trường chứng khoán.

Thậm chí, trong công tác đào tạo tư bậc giáo dục đại học hay đào tạo nhân sự chuyên sâu cũng cần nhấn mạnh tầm quan trọng và hình thành thói quen, cách suy nghĩ và hành động hướng tới minh bạch thông tin. Tăng cường giám sát và xử lý phạt nặng các vi phạm về che dấu thông tin hay không đảm bảo minh bạch thông tin gây thiệt hại cho các chủ thể tham gia thị trường. Có như vậy mới có thể cải thiện dần tình trạng bất cân xứng thông tin rất phổ biến tại các nước nghèo, chậm phát triển.

\section{3. Đảm bảo an toàn cho hệ thống tài chính}

Đảm bảo an ninh tài chính của thị trường tài chính được hiểu là việc duy trì được sự ổn định và lành mạnh tài chính trong quá trình vận hành của thị trường và hoạt động của các định chế tài chính, trên cơ sở đó, giảm thiểu và hạn chế được rủi ro trên thị trường và hệ thống tài chính. Để có thể phát triển tài chính lành mạnh, hướng đến thúc đẩy tăng trưởng kinh tế cần phải thực hiện giám sát an toàn tài chính trên thị trường tiền tệ - ngân hàng, thị trường chứng khoán, và các thị trường tài chính khác như thị trường bảo hiểm. Tiêu chí quan trọng nhất là đảm bảo tỷ lệ vốn khả dụng, và báo cáo định kỳ cho cơ quan quản lý thị trường. Cần có các quy định chặt 
chẽ và xử phạt kịp thời mang tính răn đe nếu vi phạm liên quan đến trích lập dự phòng nghiệp vụ, quy định khống chế mức đầu tư vào các tài sản được đưa ra để đảm bảo phân tán rủi ro, quy định về tỷ lệ biên khả năng thanh toán tối thiểu để đảm bảo khả năng thanh toán của các định chế tài chính trung gian. Đối với thị trường tiền tệ và hoạt động của hệ thống ngân hàng: Các chuẩn mực quốc tế như Basel II và hệ thống chỉ tiêu CAMELS nên được sử dụng để đảm bảo an toàn trong hoạt động ngân hàng.

\subsection{Chính sách tiền tệ linh hoạt}

Cần duy trì chính sách tiền tệ thích ứng và linh hoạt, củng cố tình hình tài khóa và tăng trưởng tín dụng ở mức vừa phải để củng cố khung chính sách vĩ mô và nâng cao khả năng chống chịu trước những cú sốc kinh tế. Các chính sách tiền tệ linh hoạt và giải pháp nhạy bén theo diễn biến thực tế của thị trường để phát triển tài chính nhưng việc phát triển này phải đảm bảo tối ưu hóa ở một mức phù hợp để có thể thúc đẩy tăng trưởng kinh tế. Việc tập trung một cách đúng mực vào hệ thống tài chính cần được xem xét, tránh trường hợp để cho khu vực tài chính cạnh tranh nguồn lực với các khu vực khác, gây ảnh hưởng tiêu cực lên sự tăng trưởng kinh tế. Hoạt động điều tiết thị trường của Ngân hàng Trung ương hay Ngân hàng Nhà nước cần đảm bảo tính hiệu quả, công khai, theo các chuẩn mực rõ ràng.

Mạnh dạn tham gia và thực hiện nghiêm túc khi đã tham gia các cam kết gia nhập WTO, mở cửa thị trường ngành tài chính-ngân hàng, cho phép sự tham gia hoạt động lành mạnh của các tổ chức tài chính nước ngoài. Việc tham gia của họ góp phần đa dạng hóa sản phẩm tài chính, tạo sự cạnh tranh lành mạnh giữa các ngân hàng, thúc đẩy nâng cao chất lượng dịch vụ tài chính. Muốn vậy, các quy định luật pháp liên quan cần được chính phủ ban hành và bổ sung thêm cho chặt chẽ, kết hợp việc quản lý nghiêm minh và công bằng đối với các ngân hàng thương mại.

Bản thân các ngân hàng và tổ chức tín dụng trung gian phải nỗ lực phát triển theo hướng lành mạnh, tuân theo các chuẩn mực của thế giới về kế toán và tài chính, đảm bảo phát huy nguồn vốn được chuyển từ kênh tiết kiệm sang đầu tư vào khu vực sản xuất, giảm thiểu tình hình nợ xấu tại các ngân hàng. Điều này hàm ý rằng bản 
thân các ngân hàng thương mại phải chú ý cải thiện các tác nhân xuất phát từ đặc điểm hoạt động của chính mình thì mới có thể cải thiện tỷ lệ nợ xấu và không cho tỷ lệ này gia tăng trong tương lai. Đó chính là phải tăng cường phòng ngừa rủi ro tín dụng, không chỉ bằng cách tăng số tiền vật chất (tăng trích lập dự phòng rủi ro tín dụng) mà còn phải nâng cao ý thức thận trọng đối với các khoản cho vay các khách hàng, thực sự quan tâm vào công tác kiểm soát các khoản vay sau khi giải ngân một cách thiết thực như rà soát và cải tiến các quy trình giám sát chéo trong nội bộ ngân hàng đối với các khoản cho vay, từ đó có thể giúp ngân hàng nhận diện được các khoản vay có vấn đề và có thể thương lượng, đàm phán với khách hàng nhằm mục đích tránh chuyển nhóm nợ, tránh những hoạt động sai trái trục lợi cho chính cán bộ nhân viên cho vay của ngân hàng gây ra. Thậm chí quy trình giám sát này ngày càng phải nâng cao thành giám sát chéo các lãnh đạo cấp cao của từng chi nhánh, từng bộ phận như Tín dụng, Ngân quỹ, ...Có như vậy mới giảm thiểu được vấn đề nợ xấu của ngân hàng. Có như vậy hoạt động của hệ thống ngân hàng và các thị trường tài chính mới có thể vận hành một cách hiệu quả và phát huy tác động tích cực lên tăng trưởng kinh tế.

\subsection{Phát triển khu vụ̣c tài chính đúng mực}

Như kết quả thực nghiệm của nghiên cứu này đã cho thấy, Phát triển tài chính vẫn giữ vai trò là nhân tố quan trọng trong việc làm gia tăng mức sản lượng của nền kinh tế, miễn là đừng phát triển hệ thống tài chính quá mức.

Hiện nay, theo Ngân hàng Thế giới công bố, tỷ lệ người trưởng thành không có tài khoản ngân hàng tập trung chủ yếu ở 25 quốc gia (trong đó có Việt Nam) chiếm $73 \%$ số người không có tài khoản trên toàn cầu, riêng Ấn Độ và Trung Quốc là hai quốc gia đã chiếm đến $32 \%$ tổng con số thống kê. Vì vậy, chủ trương của Ngân hàng Thế giới cho rằng phổ cập tài chính, tức là làm tăng độ tiếp cận của người dân đến hệ thống tài chính là một nhân tố quan trọng giúp giảm đói nghèo và cải thiện tăng trưởng kinh tế, nên đã đặt ra mục tiêu về Tiếp cận Tài chính Toàn cầu - UFA (Universal Financial Access) phải đạt được là đến năm 2020 trên toàn thế giới, và 
nhiều quốc gia châu Á, trong đó có Việt Nam từ năm 2016 đã đồng ý tham gia vào chương trình này. Phổ cập tài chính trở thành một trong những chủ đề đang được ưu tiên thảo luận trong chương trình nghị sự của các nhà lãnh đạo toàn cầu, tổ chức quốc tế cũng như chính phủ tại các diễn đàn đa phương quốc tế và khu vực với quy mô lớn. Đó là một định hướng đúng đắn cho phát triển tài chính của các nền kinh tế châu Á, hướng tới phát triển một hệ thống tài chính toàn diện, là hệ thống phục vụ cho tất cả các thành viên trong xã hội, cung cấp dịch vụ tài chính phù hợp và thuận tiện cho mọi thành viên xã hội với mức chi phí hợp lý, đặc biệt chú trọng đến nhóm cá nhân và tổ chức yếu thế, chưa được tiếp cận và sử dụng các dịch vụ tài chính chính thống. Những đối tượng này được tiếp cận thị trường tài chính chính thức, góp phần phân bổ và sử dụng nguồn lực có hiệu quả, thúc đẩy tăng trưởng kinh tế. Cho nên đây đang được xem là chính sách quốc gia tại nhiều nền kinh tế châu Á.

Tuy nhiên các quốc gia châu Á đang phát triển rất cần thiết phải nhận thức rõ ràng là sự phát triển tài chính là một quá trình cải thiện cả về số lượng, chất lượng và hiệu quả đem lại của hệ thống tài chính liên quan đến sự hoạt động và tương tác của nhiều tổ chức và cá nhân khác nhau trên thị trường. Phát triển tài chính cả chiều rộng lẫn chiều sâu và phát triển đúng mực thì mới phát huy được vai trò tích cực của nó là thúc đẩy tích lũy vốn, phân phối vốn hiệu quả đến các cơ hội đầu tư, tạo điều kiện thuận lợi hơn cho sản xuất và trao đổi hàng hóa dịch vụ trong nền kinh tế. Phát triển tài chính quá mức, phát triển tràn lan bằng mọi giá thì vai trò tích cực và thúc đẩy tăng trưởng kinh tế của hệ thống tài chính sẽ bị triệt tiêu.

\subsection{Hiện đại hóa hệ thống tài chính}

Cơ sở hạ tầng tài chính và công nghệ thông tin khi được phát triển mạnh mẽ, an toàn, hiệu quả và có độ bao phủ rộng sẽ góp phần đem lại hiệu quả đối với việc cung ứng các dịch vụ tài khoản giao dịch và cũng hỗ trợ cho việc cung ứng các dịch vụ tài chính khác, góp phần mở rộng mạng lưới và đa dạng hóa sản phẩm dịch vụ, thanh toán phục vụ nhu cầu đa dạng của người dân. 
Hiện đại hóa hệ thống tài chính, phát triển cơ sở hạ tầng tài chính là xu hướng tất yếu của các nước trên thế giới nói chung và các nước châu Á nói riêng. Điều này cũng góp phần thúc đẩy được các yếu tố đổi mới và cạnh tranh, tạo điều kiện thuận lợi hơn, khuyến khích phát triển thanh toán không dùng tiền mặt, hỗ trợ cho chính sách phổ cập tài chính. Hiện đại hóa hệ thống tài chính là giải pháp rất cần thiết, đặc biệt đối với các nước đang phát triển như Việt Nam, góp phần bảo đảm an ninh, an toàn trong hoạt động thanh toán, đáp ứng được yêu cầu của sự phát triển và hội nhập kinh tế quốc tế.

\subsection{Nâng cao vai trò của các chủ thể tham gia hệ thống tài chính}

Thực tế là ngày nay, nhiều nước đã nghiên cứu và không ngừng điều chỉnh các cách thức quản lý và chính sách nhằm mục tiêu tăng trưởng nhanh hơn, từ đó có thể giảm bớt khoảng cách của họ so với các quốc gia phát triển đi trước. Các nước đang còn tình trạng kém phát triển tài chính ở châu Á có thể học hỏi bài học kinh nghiệm từ Singapore. Singapore là quốc gia nhỏ nhất ở Đông Nam Á nhưng chỉ 50 năm từ khi trở thành một quốc gia độc lập năm 1965, Singapore đã có GDP bình quân đầu người tăng hơn 100 lần và trở thành nền kinh tế sánh ngang các nước phát triển phương Tây với hệ thống tài chính phát triển mạnh mẽ, vững mạnh. Ngay từ những bước đi đầu tiên, chính phủ Singapore đã chú trọng thiết lập các hội đồng khu vực tư nhân, chuyên thu thập thông tin thị trường theo giai đoạn: cụ thể là năm 1997 các hội đồng này thu thập thông tin để hình thành các định hướng, năm 1998 thông tin tập trung vào việc hỗ trợ các chủ thể quan trọng. Các hội đồng này đã thực hiện hiệu quả vai trò của họ khi đưa ra những ý tưởng mang tính cải cách, đem lại kết quả tích cực như đề xuất thiết lập hệ thống mở về quản lý và điều hành, giúp tăng vai trò tham gia của các nhà đầu tư định chế, tăng cường tính bảo mật của Ngân hàng Trung ương (MAS), thu hút cố vấn từ các tổ chức tài chính quốc tế.

Nhờ vào biện pháp nâng cao vai trò của các chủ thể tham gia vào thị trường tài chính mà Singapore có hệ thống tài chính phát triển tốt nhất, huy động tối đa nguồn vốn nhàn rỗi trong và ngoài nước và sử dụng hiệu quả để đáp ứng cho quá trình công 
nghiệp hóa và hiện đại hóa. Tại Singapore, phát triển thị trường tài chính, trong đó có thị trường vốn gắn chặt với các mục tiêu vĩ mô dài hạn như việc làm và tăng trưởng GDP, được coi là động lực của nền kinh tế. Singapore đã trở thành một trong những thị trường vốn dẫn đầu trong khu vực châu Á, trở thành một trong 4 trung tâm tài chính lớn của thế giới, thị trường ngoại hối đứng thứ 4 thế giới chỉ sau London, New York và Tokyo, vượt qua cả Hong Kong. Năm 2016, Singpore đứng thứ hai bảng xếp hạng các thành phố có môi trường kinh doanh tài chính tốt nhất toàn cầu. Theo dự đoán của tập đoàn tư vấn Boston, đến năm 2020, Singapore sẽ trở thành trung tâm tài chính lớn thứ hai trên thế giới.

Từ kinh nghiệm thực tiễn này của Singapore, các nước thuộc nhóm còn chậm phát triển về thị trường tài chính có thể học hỏi để đưa ra sách lược cụ thể cho chính quốc gia của mình nhưng phải chú trọng vào tất cả các chủ thể trên thị trường chứ không nên tạo ra những ưu đãi đặc thù cho các định chế tài chính do chính phủ quản lý. Có như vậy mới tạo ra sân chơi công bằng và khuyến khích khích tăng tính cạnh tranh trên thị trường tài chính.

\subsection{Các ý kiến đề xuất khác}

Luận án cũng tìm thấy những kết luận liên quan đến biến kiểm soát. Trên cơ sở này, các ý kiến được đề xuất liên quan đến các nhân tố này. Đây cũng là các nhân tố quan trọng đóng góp vào việc tăng trưởng cho nền kinh tế:

$\checkmark$ Cần giảm chi tiêu Chính phủ để giảm bội chi ngân sách, đảm bảo an ninh tài chính. Cải thiện hiệu quả sử dụng các khoản chi của chính phủ để khoản tiền ngân sách chi tiêu đem lại tác động tích cực cho GDP.

$\checkmark$ Đầu tư cơ sở hạ tầng là cần thiết cho sự phát triển của nền kinh tế, nhất là các nước thị trường mới nổi ví dụ như Việt Nam nhưng cần đầu tư tập trung và hiệu quả, hạn chế đầu tư sai lệch mục tiêu bằng cách thẩm định kỹ trước khi đầu tư, tăng cường hiệu quả đầu tư từ vốn nhà nước; cơ chế quản lý cần rõ ràng, làm rõ trách nhiệm, quyền hạn của các chủ thể trực tiếp tham gia quản lý, sử dụng nguồn vốn nhà nước; sử dụng nguồn vốn ODA và khuyến khích 
hợp tác đầu tư Nhà nước - Tư nhân (PPP) để phát triển kết cấu hạ tầng, bổ sung cho các nguồn lực công.

$\checkmark$ Tăng cường vai trò giám sát, tư vấn của các tổ chức chính trị - xã hội; Xây dựng mới, bổ sung, sửa đổi các quy định liên quan của pháp luật hiện hành cũng là giải pháp cần thiết để phối hợp với các giải pháp nêu trên để nền kinh tế có thể đạt mức tăng trưởng cao ổn định.

$\checkmark$ Đẩy mạnh cải cách cơ cấu, bao gồm cả cải cách doanh nghiệp và khu vực ngân hàng, kết hợp với cải thiện hiệu suất đầu tư công là cách để nâng cao năng suất và sản lượng tiềm năng. Bên cạnh đó cũng thực hiện các chính sách tạo thuận lợi thương mại, đẩy mạnh tự do hóa thương mại sẽ giúp các quốc gia đang phát triển châu Á nâng cao năng lực cạnh tranh xuất khẩu, thúc đẩy tăng trưởng kinh tế.

$\checkmark$ Tiếp tục hoàn thiện hành lang pháp lý, các cơ chế, chính sách cho hoạt động của hệ thống tài chính, cải thiện môi trường thể chế để thu hút đầu tư cho sản xuất ra hàng hóa dịch cụ trong nền kinh tế, thu hút vốn đầu tư vào thị trường tài chính, và cả thu hút nguồn vốn con người - tức là những lao động chất lượng cao. Có như vậy mới thúc đẩy được tăng trưởng kinh tế và duy trì điều này trong dài hạn.

$\checkmark$ Khi một quốc gia đẩy mạnh phát triển tài chính, quá trình tự do hóa tài chính diễn ra có thể làm gia tăng tình trạng mỏng manh dễ bị tổn thương của hệ thống tài chính, nhất là tại các nước đang phát triển như Việt Nam. Đây cũng là những quốc gia mà thể chế chặt chẽ và phù hợp rất cần thiết để hỗ trợ cho hệ thống tài chính vận hành hiệu quả vẫn chưa được thiết lập hoàn chỉnh. Vì vậy, cần hoàn thiện và bổ sung các quy định pháp lý liên quan đến hoạt động tài chính trong cả hai phương diện, khu vực ngân hàng lẫn thị trường tài chính, sao cho phát huy được các lợi ích từ hội nhập tài chính, tự do hóa tài chính nhưng đồng thời cũng kiểm soát được rủi ro phát sinh từ quá trình này như sự đảo ngược của dòng vốn khiến nền kinh tế rơi vào khủng hoảng (Thái Lan) 
hay dòng vốn đổ vào nền kinh tế ào ạt gây tăng trưởng nóng quá mức như Trung Quốc 2005 cũng có nguy cơ gây ra khủng hoảng. Cải cách thể chế nhưng thực hiện không đồng bộ, xây dựng quy định pháp lý thuần túy mà không kết nối cho phù hợp thực tiễn cũng là những tồn tại chung ở các quốc gia đang phát triển châu Á như Việt Nam cần phải chú trọng cải thiện thì mới đạt được tăng trưởng trong dài hạn bền vững. Môi trường thể chế tốt sẽ hỗ trợ cho việc phân bổ các nguồn lực trong nền kinh tế hiệu quả hơn, qua đó cũng cải thiện tính hiệu quả cho chi tiêu công và thúc đẩy đầu tư, là những yếu tố mà luận án này đã xác nhận có ảnh hưởng đáng kể đến tăng trưởng của nền kinh tế.

\subsection{Hạn chế của đề tài và hướng nghiên cứu trong tương lai}

Trên đây là một số khuyến nghị của tác giả từ kết quả nghiên cứu, hy vọng làm tài liệu tham khảo hữu ích cho giới chuyên môn và các nhà hoạch định chính sách. Đóng góp của nghiên cứu này là thực hiện trên mẫu các quốc gia châu Á bổ sung thêm khoảng trống của các nghiên cứu trước đây còn bỏ ngỏ.

Tuy nhiên, nghiên cứu này cũng không tránh khỏi mặt hạn chế là số quốc gia có đủ dữ liệu để thu thập còn ít, nên cỡ mẫu nhỏ. Đây cũng là hướng nghiên cứu mở rộng cho tác giả sau này khi khắc phục được khó khăn trong tiếp cận số liệu, mở rộng mẫu quan sát lớn hơn. Một số biến trong mô hình chưa đạt được ý nghĩa thống kê như biến thể chế, nguồn vốn con người, lạm phát. Trong phân tích, ý nghĩa thống kê biểu đạt một kết quả không xảy ra do ngẫu nhiên. Có thể, do tính khác biệt nhiều về thể chế chính trị và các trị số phản ánh nguồn vốn con người ở các quốc gia trong mẫu, nên các kết luận tìm thấy chưa thể gọi là cùng quy luật nên không đạt ý nghĩa thống kê. Vì vậy, một hướng nghiên cứu trong tương lai là nghiên cứu thêm các nhân tố khác đến tăng trưởng kinh tế như địa chính trị, phát triển khoa học công nghệ, đổi mới sáng tạo, thể chế chính trị, văn hóa quốc gia để có những phân tích chuyên sâu phù hợp với những nền kinh tế đang phát triển, có thể chế chính trị khác biệt như Trung Quốc, Việt Nam và phù hợp với thế giới đang hướng đến cách mạng công 
nghiệp 4.0. Bên cạnh đó, luận án này chưa đánh giá tác động của khủng hoảng tài chính 2008 đến mối quan hệ giữa phát triển tài chính và tăng trưởng kinh tế, chỉ mới tập trung đi sâu phân tích những biến chuyển của bối cảnh hậu khủng hoảng dẫn đến đòi hỏi phải nhìn nhận lại vai trò và cách thức phát triển của phát triển tài chính. Trong những nghiên cứu tiếp theo, tác giả sẽ tiếp tục phát triển mở rộng mảng nghiên cứu này. 


\section{DANH MỤC CÁC CÔNG TRÌNH ĐÃ CÔNG BỐ}

1) Phan Thị Bích Nguyệt \& Phạm Dương Phương Thảo (2018). Giới hạn phát triển hệ thống tài chính ngân hàng tại các quốc gia châu Á. Tạp chí Khoa học \& Đào tạo ngân hàng, Số 199-Tháng 12/2018

2) Phan Thị Bích Nguyệt \& Phạm Dương Phương Thảo (2018). Ngưỡng phát triển tài chính hướng đến tăng trưởng kinh tế bền vững cho các quốc gia châu Á. Tạp chí Tài chính, Kỳ 2-Tháng 12/2018

3) Phạm Dương Phương Thảo (2018). Ảnh hưởng của ngưỡng phát triển thị trường tài chính nhằm tăng trưởng kinh tế tại các nước đang phát triển châu Á. Kỷ yếu Hội thảo khoa học Quốc gia năm 2018 "Kế toán - Kiểm toán - Tài chính Việt Nam, Thưc trạng và phương huoóng hoàn thiện”, NXB Tài chính, ISBN: 978-60479-1828-7.

4) Phạm Dương Phương Thảo (2018). Úng dụng mô hình ngưỡng để phân tích tác động của phát triển tài chính đến tăng trưởng kinh tế. Kỷ yếu Hội thảo khoa học "Mô hình trong tài chính: Lý thuyết \& Thực nghiệm”, NXB Kinh tế Tp,HCM, ISBN: 978-604-922-641-0

5) Phan Thị Bích Nguyệt \& Phạm Dương Phương Thảo (2016). Tăng trưởng kinh tế và phát triển tài chính tại các quốc gia đang phát triển châu Á. Tạp chí Phát triển và Hội nhập, 28(38), 69-74.

Đề tài nghiên cứu cấp cơ sở (2015), Thành viên, "Nghiên cứu tác động của phát triển tài chính đến tăng trưởng kinh tế quốc gia: Bằng chứng thực nghiệm tại VN và các quốc gia châu Á" - nghiệm thu đạt loại Tốt. 


\section{TÀI LIỆU THAM KHẢO}

Aizenman, J., Y. Jinjarak, and D. Park, 2015. Financial Development and Output Growth in Developing Asia and Latin America: A Comparative Sectoral Analysis. NBER Working Paper 20917 National Bureau of Economic Research, Cambridge, Massachusetts

Ang, J.B., and Mckibbin, W.J. 2007. Financial Liberalization, Financial Sector Development and Growth: Evidence from Malaysia. Journal of Development Economics, 84(1), 215-233.

Ang, J.B, 2009. Financial Development and Economic Growth in Malaysia. Routledge Studies in the Growth Economies of Asia.

Anwar, S. \& Lan Phi Nguyen, 2011. Financial development and economic growth in Vietnam. Journal of Economics and Finance, 35, 348-360.

Andersen, T.B., Tarp, F., 2003. Financial liberalization, financial development and economic growth in LDCs. Journal of International Development, 15 (2), 189209

Arcand, J., Berkes, E., Panizza, U., 2012. Too Much Finance? International Monetary Fund.Research Department.

Arestic, P. \& P. Demetriades. 1997. Financial development and economic growth: Assessing the evidence. The Economic Journal, 107 (May), 783-799.

Arrow, K.J. 1962. The Economic Implications of Learning by Doing. Review of Economic Studies 29: 155-173.

Arrow, K.J. 1964. The role of securities in the optimal allocation of risk bearing. Review of Economic Studies, vol. 31, issue 2, 91-96

Barro, R. J., 1991. Economic growth in a cross section of countries. Quarterly Journal of Economics, 106, 407-443.

Barro, R. J., \& Lee, J. W. 1993. International comparisons of educational attainment. Journal of monetary economics, 32(3), 363-394

Bayar, Y., 2014. Financial Development and Economic Growth in Emerging Asian Countries. Asian Social Science, Vol. 10, No. 9 
Beck, T., Levine, R., \& Loayza, N., 2000. Finance and the sources of growth. Journal of Financial Economics, 58(1), 261-300

Beck, T., Levine, R., 2004. Stock markets, banks, and growth: panel evidence. Journal of Banking and Finance 28 (3), 423-442.

Beck, T., Demirgüç-Kunt, A., Maksimovic, V., 2005. Financial and legal constraints to firm growth: does size matter? Journal of Finance 60 (1), 137-177.

Beck, T., Degryse, H., \& Kneer, C., 2014. Is more finance better? Disentangling intermediation and size effects of financial systems. Journal of Financial Stability, $10,50-64$.

Bencivenga, V. R., \& Smith, B. D., 1991. Financial intermediation and endogenous growth. The Review of Economic Studies, 58(2), 195-209.

Ben-David, D. 1993. Equalizing exchange: Trade liberalization and income convergence. Quarterly Journal of Economics, 108(3).

Benhabib, J. \& Spiegel, M. M., 1994. The role of human capital in economic development evidence from aggregate cross-country data, Journal of Monetary Economics, Elsevier, vol. 34(2), 143-173.

Bernanke, B., M. Gertler, and S. Gilchrist. 1999. The Financial Accelerator in a Quantitative Business Cycle Framework, NBER Working Paper 6455, National Bureau of Economic Research, Cambridge, Massachusetts

Boyd, J.H. \& A.M. Jalal., 2012. A new measure of financial development: Theory leads measurement. Journal of Development Economics, 99, 341-357.

Campos, N. F., \& Kinoshita, Y., 2008. Foreign direct investment and structural reforms: Evidence from Eastern Europe and Latin America. Washington, DC: International Monetary Fund, IMF Institute.

Cecchetti, G., \& Kharroubi, E., 2012. Reassessing the impact of finance on growth. BIS Working Paper No. 381. Bank for International Settlements.

Chandavarkar, A. 1992. Of finance and development: Neglected and unsettled questions. World Development 20 (1): 133-42. 
Christopoulos, D. K., \& Tsionas, E. G., 2004. Financial development and economic growth: Evidence from panel unit root and cointegration tests. Journal of Development Economics, 73(1), 55-74.

Chuah. H. L., \& Thai, W., 2004. Financial development and economic growth: Evidence from causality tests for the GCC countries. IMF Working Paper.

Cihak, M., A. Demirgüç-Kunt, E. Feyen, R. Levine, 2012. Benchmarking Financial Development Around the World, World Bank Policy Research, Working Paper 6175, August 2012, World Bank, Washington, DC.

Cohen, D. \& M. Soto. 2007. Growth and human capital: good data, good results. Journal of Economic Growth, Springer, vol. 12(1), 51-76

Dabla-Norris, E. \& N. Srivisal, 2013. Revisiting the Link between Finance and Macroeconomic Volatility. IMF Working Paper 13/29. Washington: International Monetary Fund (January)

De Gregorio, J. \& Guidotti, P. 1995. Financial development and economic growth. World Development 23 (3), 433-448.

Deidda, L., \& Fattouh, B., 2002. Non-linearity between finance and growth. Economics Letters, 74(3), 339-345.

Demetriades, P. O., \& Hussein, K. A., 1996. Does financial development cause economic growth? Time-series evidence from 16 countries. Journal of Development Economics, 51(2), 387-412.

Dollar, D. 1992. Outward-oriented developing economies really do grow more rapidly: Evidence from 95 LDCs, 1976-85. Economic Development and Cultural Change, 523-544.

Dollar, D., \& Kraay, A., 2003. Institutions, trade, and growth. Journal of International Economics, 50, 133-162.

Domar, E.D., 1946. Capital Expansion, Rate of Growth, and Employment. Econometrica, 14, pp.137-147

Dorrucci, E., Meyer-Cirkel, A., Santabarbara, D., 2009. Domestic Financial Development in Emerging Economies Evidence and Implications. Occasional paper Series, No: 102. European Central Bank (http://ssrn.com/abstract_id=1325243). 
Durusu, D., Serdar, I.M, Yetkiner, H. 2016. Financial Development and Economic Growth: Some Theory and More Evidence. Journal of Policy Modeling, 39, 290-306.

Ergungor, O.E., 2008. Financial system structure and economic growth: structure matters. International Review of Economics and Finance 17 (2), 292-305.

Easterly, W., \& Levine, R. 2001. What have we learned from a decade of empirical research on growth? It's not factor accumulation: Stylized facts and growth models. World Bank Economic Review, 15(2), 177-219.

Edwards, S. 1998. Openness, productivity and growth: What do we really know?. Economic Journal, 108, 383-398

Ericsson, N. R., Irons, J. S., \& Tryon, R. W., 2001. Output and inflation in the long run. Journal of Applied Econometrics, 16(3), 241-253.

Estrada, G., D. Park, \& A. Ramayandi. 2010. Financial Development and Economic Growth in Developing Asia, ADB Working Economic Series, No.233

Favara, G., 2003. An empirical reassessment of the relationship between finance and growth. IMF Working Paper No. 03/123.

Frankel, J., \& Romer, D. 1999. Does trade cause growth? American Economic Review, 89, 379-399.

Fry, M. J. 1997. In favour of financial liberalisation. The Economic Journal, 107(442), 754-770.

Girma, S. 2005. Absorptive capacity and productivity spillovers from FDI: A threshold regression analysis export. Oxford Bulletin of Economics and Statistics 67: 281-306

Goldsmith, R. W., 1969. Financial structure and development. New Haven: Yale University Press.

Greenwood, J., \& Jovanovic, B., 1990. Financial development, growth, and the distribution of income. London, Ont., Canada: Dept. of Economics, Social Science Centre, University of Western Ontario

Gurley, J. G., \& Shaw, E. S., 1955. Financial aspects of economic development. The American Economic Review, 45(4), 515-538. 
Hansen, B.E., 1999. Threshold effects in non-dynamic panels: Estimation, testing, and inference. Journal of Econometrics 93 (1999) 345-368

Hansen, B.E., 2000. Sample splitting and threshold estimation. Econometrica 68 (3), 575-603.

Hansen, Lars Peter, 1982. Large Sample Properties of Generalized Method of Moments Estimators. Econometrica 50 (4): 1029-1054

Hanushek, E.A. \& D.D. Kimko. 2000. Schooling, Labor-Force Quality, and the Growth of Nations. American Economic Review, Vol.90, No.5, 1184-1208.

Harrison, A. 1996. Openness and growth: A time-series, cross-country analysis for developing countries. Journal of Development Economics, 48, 419-447.

Harrod, R.F., 1939. An Essay in Dynamic Theory. Economic Journal 49, 14-33.

Hartmann, P., Heider, F., Papaioannou, E., Duca, M.L., 2007. The Role of Financial Markets and Innovation in Productivity and Growth in Europe. Occasional Paper Series No: 72. European Central Bank

Hermes, N. \& R. Lensink. 2000. Financial system development in transition economies. Journal of Banking \& Finance, 2000, vol. 24, issue 4, 507-524.

Huang, H. C., \& Lin, S. C., 2009. Non-linear finance-growth nexus. Economics of Transition, 17, 439-466.

Hsueh, Shun-Jen, Yu-Hau Hu, Chien-Heng Tu. 2013. Economic growth and financial development in Asian countries: A bootstrap panel Granger causality analysis. Economic Modelling, 32, 294-301.

Irwin, D. A., \& Tervio, M. 2002. Does trade raise income? Evidence from the twentieth century. Journal of International Economics, 58(1), 1-18.

Iyare, S. \& W. Moore. 2011. Financial sector development and growth in small open economies. Applied Economics, Volume 43, Issue 10: 1289-1297.

Jalil, A. and Feridun, M. 2011. Impact of financial development on economic growth: Empirical evidence from Pakistan. Journal of the Asia Pacific Economy 16(1):71-80. 
Jeanneney, S.G., P. Hua, Z. Liang. 2006. Financial development, economic efficiency, and productivity growth: Evidence from China. Developing Economies, $44,27-52$

Johannes, T.A., Njong, A.M., Cletus, N., 2011. Financial development and economic growth in Cameroon, 1970-2005. Journal of Economics and International Finance, 3, 367-375.

Kar, M., Nazlioglu, S., \& Agir, H., 2011. Financial development and economic growth nexus in the MENA countries: Bootstrap panel granger causality analysis. Economic Modelling, 28(1), 685-693.

Keynes, J.M., 1936. The General Theory of Employment, Interest and Money. New York: Harcourt, Brace \& World, Inc.

Kelly, T., 1997. Public Expenditures and Growth. Journal of Development Studies 34: $60-84$

Khan, M. S., \& Senhadji, A. S., 2003. Financial development and economic growth: A review and new evidence. Journal of African Economies, 12(2), 89-110.

King, G.R., Levine, R., 1993a. Finance and growth: Schumpeter might be right. Quarterly Journal of Economics 108 (3), 717-737.

King, G.R., Levine, R., 1993b. Finance, entrepreneurship and growth. Journal of Monetary Economics 32 (3), 1-30.

Knoop, T.A., 1999. Growth, Welfare, and the Size of Government. Journal of Economic Inquiry 37(1): 103-119

Krueger, A.B. \& Lindahl, M. 2001. Education for Growth: Why and for Whom?. Journal of Economic Literature, American Economic Association, vol. 39(4), pages 1101-1136.

Law, S. H., \& Singh, N., 2014. Does too much finance harm economic growth? Journal of Banking and Finance, 41, 36-44.

Law, S.H., Azman-Saini, W.N.W., Ibrahim, M.H., 2013. Institutional quality thresholds and finance-growth nexus. Journal of Banking and Finance 37 (12), 5373-5381. 
Levine, R., 1997. Financial development and economic growth: views and agenda. Journal of Economic Literature 35 (2), 688-726.

Levine, R., Zervos, S., 1998. Stock markets, banks and economic growth. American Economic Review 88 (3), 537-558.

Levine, R., Loayze, N., Beck, T., 2000. Financial intermediation and growth: causality and causes. Journal of Monetary Economics 46 (1), 31-77.

Levin, A., Lin, C.-F., \& Chu, C.-S. J. 2002. Unit root tests in panel data: Asymptotic and finite-sample properties. Journal of Econometrics, 108, 1-24.

Levine, R., 2002. Bank-based versus market-based financial systems: which is better? Journal of Financial Intermediation 11 (4), 398-428.

Levine, R., 2003. More on finance and growth: more finance, more growth? Federal Reserve Bank of St. Louis Review 85 (July), 31-46.

Levine, R., 2005. Finance and Growth: Theory and Evidence, Handbook of Economic Growth, in: Philippe Aghion \& Steven Durlauf (ed.), Handbook of Economic Growth, edition 1, volume 1, chapter 12, pages 865-934 Elsevier.

Loayza, N. V., \& Rancie`re, R. 2006. Financial development, financial fragility, and growth. Journal of Money, Credit and Banking, 38(4), 1051-1076.

Lopez, L. \& S. Weber. 2017. Testing for Granger causality in panel data. The Stata Journal, 17, Number 4, 972-984

Lucas, R. E., 1988. On the mechanics of economic development. Journal of Monetary Economics, 22, 3-42

Noureen, A., 2011. Measurement of Financial Development: A Fresh Approach. 8th International Conference on Islamic Economics and Finance

Mankiw, N. G., Romer, D., \& Weil, D., 1992. A contribution to the Empirics of Economic Growth. Quarterly Journal of Economics, 107, 407-438

Mankiw, N. G, 2011. Kinh tế học vĩ mô. Dịch từ tiếng Anh. Người dịch: GV Đại học Kinh tế Tp.HCM, 2014. Singapore: Cengage Learning.

McKinnon, R.I., 1973. Money and capital in economic development. Washington: Brookings Institution Press. 
Mitchell, D., 2005. The Impact of Government Spending on Economic Growth. The Heritage Foundation, No.1831

Myers, S., 1984. The capital structure puzzle. Journal of Finance 39, 575-592.

Myers, S., \& Majluf, N., 1984. Corporate financing and investment decisions when firms have information that investors do not have. Journal of Financial Economics 13, 187-221.

Nişanc1, M., Karabıyık, İ., \& Uçar, M., 2011. Finansal gelişme ve iktisadi büyüme: Statik ve dinamik panel verianalizi. Selçuk Üniversitesi İIBF Sosyal ve Ekonomik Araştırmalar Dergisi, 16(22), 107-118

Owen, A. L., \& Temesvary, J., 2014. Heterogeneity in the growth and finance relationship: How does the impact of bank finance vary by country and type of lending? International Review of Economics and Finance, 31, 275-288.

Patrick, H. T., 1966. Financial development and economic growth in underdeveloped countries. Economic Development and Cultural Change, 14, 174189.

Portela, M., R. Alessie, and C. Teulings. 2004. Measurement error in education and growth regressions. Discussion Paper No. 4637, Centre for Economic Policy Research, London

Puatwoe, J., Piabuo, S., 2017. Financial sector development and economic growth: evidence from Cameroon. Financial Innovation, 3, 1-18.

Rajan, R., Zingales, L., 1998. Financial dependence and growth. American Economic Review 88 (3), 559-586.

Rajkumar, A.S. và Swaroop, V., 2008. Public Spending and Outcomes Does Governance Matter. Journal of Development Economics, 86, 96-111

Ricardo, D., 1817. On the Principles of Political Economy and Taxation. London: John Murray, 1821.

Rioja, F., \& Valev, N., 2004a. Finance and the sources of growth at various stages of economic development. Economic Inquiry, 42, 127-140. 
Rioja, F., \& Valev, N., 2004b. Does one size fit all? A reexamination of the finance and growth relationship. Journal of Development Economics, 74(2), 429447.

Romer, P. M., 1986. Increasing returns and long run growth. Journal of Political Economy, 94(5), 1002-1037.

Romer, P. M., 1990. Endogenous Technological Change. Journal of Political Economy, 98, 71-102.

Rousseau, P. L., \& Wachtel, P. 2002. Inflation thresholds and the finance-growth nexus. Journal of International Money and Finance, 21(6), 777-793

Rousseau, P. L., \& Wachtel, P., 2011. What is happening to the impact of financial deepening on economic growth? Economic Inquiry, 49(1), 276-288

Sachs, J., \& Warner, A. 1995. Economic reform and the process of global integration. Brookings Papers on Economic Activity, 1-118.

Sahay, R., Martin C., Papa N'Diaye, Adolfo B., Ran Bi, Diana A., Yuan G., Annette K., Lam Nguyen, Christian S., Katsiaryna S., \& Seyed R.Y., 2015. Rethinking Financial Deepening: Stability and Growth in Emerging Markets, IMF Staff Discussion Note.

Samargandi, N., J. Fidrmuc, S. Ghosh., 2014. Is the relationship between Financial Development and Economic Growth monotonic? Evidence from a sample of Middle-income countries. World Development, Vol. 68, pp. 66-81.

Sahay, R., Martin C., Papa N'Diaye, Adolfo B., Ran Bi, Diana A., Yuan G., Annette K., Lam Nguyen, Christian S., Katsiaryna S., \& Seyed R,Y., 2015. Rethinking Financial Deepening: Stability and Growth in Emerging Markets. IMF Staff Discussion Note

Schumpeter, J.A., 1911. The Theory of Economic Development: An Inquiry into Profits, Capital, Credit, Interest, and the Business Cycle. Cambridge, MA: Harvard University Press

Schumpeter, J. A., \& Opie, R., 1934. The theory of economic development: An inquiry into profits, capital, credit, interest, and the business cycle. Cambridge, Mass.: Harvard University Press. 
Sehrawat, M., Giri, A.K. 2014. Financial development and economic growth: empirical evidence from India. Studies in Economics and Finance, 32, 340-356.

Shaw, E. S., 1973. Financial deepening in economic development. New York: Oxford University Press

Shen, Chung-Hua \& Lee, Chien-Chiang. 2006. Same Financial Development Yet Different Economic Growth: Why? Journal of Money, Credit and Banking, vol. 38, issue 7, 1907-1944.

Shun-Jen H., Y. Hu, C.Tu. 2013. Economic growth and financial development in Asian countries: A bootstrap panel Granger causality analysis. Economic Modelling 32 (2013) 294-301

Shyam-Sunder, L., Myers, S., 1999. Testing static trade-off against pecking order models of capital structure. Journal of Financial Economics 51, 219-244

Smith, A. 1776. An Inquiry into the Nature and Causes of the Wealth of Nations. $1^{\text {st }}$ ed. London: W. Strahan.

Solow, R., 1956. A Contribution to the Theory of Economic Growth. Quarterly Journal of Economics 70, 65-94

Solow, R., 1994. Perspectives on growth theory. Journal of Economic Perspectives, Winter, 45-54.

Svirydzenka, K. 2016. Introducing a New Broad-based Index of Financial Development. IMF Working Paper, WP/16/5, January 2016.

Swan, T.W., 1956. Economic Growth and Capital Accumulation. Economic Record, Vol.32, 324-361

Tee, Lain-Tze, Soo-Wah Low, Si-Roei Kew, Noor A. Ghazali. 2014. Financial Development and Innovation Activity: Evidence from Selected East Asian Countries. Prague Economic Papers, 2.

Wahab, M., 2004. Economic growth and government expenditure: evidence from a new test specification. Applied Economics 36: 2126-2127

Wang, Q. 2015. Fixed-effect panel threshold model using Stata. The Stata Journal 15 , Number 1, 121-134

Weil, D.N., 2013. Economic Growth, $3^{\text {rd }}$ ed. USA: Pearson 
Phạm Minh Chính, Vương Quân Hoàng. (2009). Kinh tế Việt Nam: Thăng trầm và Đột phá. Nhà xuất bản Chính trị Quốc gia, Hà Nội

Vương Quân Hoàng. (2010). Kinh tế Việt Nam 2009 và một vài suy nghĩ về nhận thức luận chuyển đổi. Tạp chí Cộng sản, Số 807, tr. 49-55.

Vương Quân Hoàng, Phạm Minh Chính, Trần Trí Dũng, 2010. Những thời kỳ biến động của nền kinh tế Việt Nam: Bản chất của vấn đề và giải pháp cho tương lai. Tạp chí Cộng sản, số 792. 